





\section{RUWENZORI EXPEDITION REPORTS.-16. AVES.}

BY W. R. OGILVIE-GRANT, F.Z.S., M.B.O.U.

[Extracted from the 'TRansactions of The ZooLogtcal Socrery of London,' Vol, xix. Part iv., March, 1910.] 

RUWENZORI EXPEDITION REPORTS.

\author{
16. AVES. \\ By W. R. Ogilvie-Grant, F.Z.S. M.B.O.U., de. \\ ApPENDix.-On some Points in the Anatomy of Bradypterus cinnamomeus. \\ By W. P. Prcraft, F.Z.S., M.B.O.U., \&c. \\ Receised and read November $17,1908$.
}

[Plates X.-XIX.* and Text-figures 13-16.]

INTRODUCTION.

OF the collections formed by the Members of the Ruwenzori Expedition probably none is so complete as that of the Birds. 'This is partly due to the fact that as four of the collectors were specially interested in Ornithology, every effort was made to obtain examples of all the species to be met with on the range. It is thus pretty certain that of the different kinds of birds to be found on Ruwenzori very few are not represented in the present collection.

The only known exceptions are a small Swift, seen at about $10,000 \mathrm{ft}$; ; an $\mathrm{Owl}$; possibly a Pigeon, which is described as a "Black Dove," and may have been the young of Haplopetia jacksoni; and a large species of Francolin. The latter frequented the thickest parts of the forest and, though its cry might constantly be heard, its skulking habits baffled all the efforts made to procure specimens. Mr. Carruthers actually succeeded in shooting one, but the bird being only winged instantly disappeared among the dense jungle.

In addition to these there are also two species, Cryptospiza shelleyi (of which only the type-specimen is known) and Nectarinia melanogastra, which were not met with by the present Expedition, but which were procured by Mr. Geoffrey Archer on Ruwenzori, though the exact locality was not recorded. Euprinoides nigrescens, which was also said to have been procured on Ruwenzori by the same collector (cf. Jackson, 'Ibis,' 1906, p. 547), was no doubt obtained in Ankoli, as is shown by the date, April the 8th, 1902 (see Arsher, Itinerary, p. 506).

It is, of course, more than likely that, in addition to those mentioned, other species may have been overlooked and that locally distributed forms may occur in valleys which were not visited by the Expedition. As an instance of this I may mention that of a very handsome Sun-bird (Nectarinia purpureiventris) only one example was procured by Mr. Gerald Legge during the four months spent in the Mubuku Valley; while

* For explanation of the Ýlates, see pp. 462-480.

VOL. XIX.-PART IV. No. 34.-March, 1910. 
Mr. Geoffrey Archer, who remained only a few days in the same locality, procured a series of examples in all stages of plumage.

Two species peculiar to Ruwenzori, Cinnyris stuhlmanni and Parus fasciiventris, were procured by Dr. Stuhlmann in 1893, probably high up in the Butagu Valley, on the west side of Ruwenzori.

The splendid Touraco, Gallirex johnstoni, was discovered on Ruwenzori by Sir H. H. Johnston in 1901 at an elevation of about $7000 \mathrm{ft}$.

In addition to these, as already stated in my Preface, before the present Expedition had reached Ruwenzori, 14 species peculiar to the range had been procured by Mr. Geoffrey Archer, who spent twenty days on its north-eastern slopes in 1902.

Besides the species peculiar to the Ruwenzori range, many which were obtained on the lower slopes and in the surrounding country have a much wider distribution and represent elements of various other faunas, chiefly eastern and western. I have therefore attempted by means of the following lists to divide the collection as a whole into its component parts and to give some idea of their relative importance and connections.

It is difficult to account for the occurrence of certain species on Ruwenzori: for instance, a very large and remarkable Yellow-breasted Bush-Shrike (Laniarius lagdeni) was met with at $9000 \mathrm{ft}$. and subsequently procured, in some numbers, by Herr Rudolf Grauer on the higher slopes of the Mufumbiro Volcanoes, which lie to the south. This very handsome bird had for many years been known only from the type-specimen in the British Museum, obtained by Sir Godfrey Lagden in Ashanti, and its recurrence in the highlands of Central Africa is therefore as unexpected as it is remarkable. As will be seen from the following list, many West-African species, especially those found in Cameroon, occur in the Lake-district; but in the case of L. lagdeni we have to deal with a species which was said to have been originally met with in the interior of the Gold Coast, where there are no high mountains.

As the investigation of the fauna of Ruwenzori was the main object of the present Expedition, I shall first deal with the birds which are believed to be peculiar to the range, and which, so far as I am aware, have not been found elsewhere. These species, which number 20, are as follows:-

Sitagra aliena Sharpe. $5500-8500 \mathrm{ft}$.

Cryptospiza jacksoni Sharpe. $6000-8500 \mathrm{ft}$.

, shelleyi Sharpe. (Exact locality unknowa.)

Nectarinia dartmouthi Grant. 12,500-14,500 ft. Cinnyris alinæ (Jackson). $\quad 5500-9000 \mathrm{ft}$.

, stuhlmanni Reichenow. 10,000$11,200 \mathrm{ft}$.

Parus fasciiventris Reichenow. $6500-11,000 \mathrm{ft}$. Dryoscopus holomelas Jackson. $6000-9000 \mathrm{ft}$. Bradypterus barakæ Sharpe. 6500-8500 ft.
Apalis affinis Grant. $6000 \mathrm{ft}$.

, personata Sharpe. $6000-9000 \mathrm{ft}$.

"ruwenzori Jackson. 6000-9000 ft. Cossypha archeri Sharpe. 6000-13,000 ft. Alethe poliophrys Sharpe. $\quad 6500-9000 \mathrm{ft}$. Batis diops Jackson. $\quad 6500-8500 \mathrm{ft}$. Cryptolopha alpina Grant. 10,000-14,000 ft. , læta Sharpe. 6500-9000 ft. Gallirex johnstoni Sharpe. $8500-11,000 \mathrm{ft}$. Cypselus maximus Grant. 10,000-14,000 ft. Haplopelia jacksoni Sharpe. $6500-9000 \mathrm{ft}$. 
The following 6 species found on the Ruwenzori range have also been met with on the Mufumbiro Volcanoes, which lie to the south:-

Cryptospiza ocularis Sharpe. $6000-7000 \mathrm{ft}$. Serinus graneri Hartert. $5500-14,000 \mathrm{ft}$.

Nectarinia purpurciventris Reichenow。 $7000 \mathrm{ft}$.
Cinnyris regius Reichenow. $6000-10,000 \mathrm{ft}$. Turdinus atriceps Sharpe. $6500-9000 \mathrm{ft}$. Tarsiger ruwcnzori Grant. $\quad 6500-12,000 \mathrm{ft}$.

The portion of the collection which was formed in the neighbourhood of Entebbe, at the north end of Victoria Nyanza, is of special interest. Entebbe may be regarded as a great central junction where elements of all the tropical Faunas meet. Most of the more widely ranging species of birds belonging to the East-African, TVhite Nile, WestAfrican, Angolan, and South-African Faunas are to be met with there, and probably there is no spot on the African continent where so many different species are to be found.

The following 96 species are characteristic of the great central chain of Lakes, some being confined to the neighbourhood of Victoria Nyanza, while others range northwards to the Bahr-el-Jebel, or as far south as Lake Nyasa:-

Oriolus percivali.

Malimbus centralis.

$$
\text { , fagani. }
$$

Cinnamopteryx mpangæ.

Sycobrotus mentalis.

Heterhyphantes stephanophorus.

Hyphantoruis dimidiatus.

$$
\text { , feminina. }
$$

Sitagra pelzelui.

Amblyospiza melanonota.

Quelea cardinalis.

Pyromelana ansorgei.

$$
\begin{aligned}
& \text {, nigrifrons. } \\
& \text {, crassirostris. }
\end{aligned}
$$

Urobrachya phocuicea.

Coliuspasser soror.

Pytelia belli.

Nigrita schistacea.

Nesocharis ansorgei.

Estrilda minor. (South to the Zambesi R.)

$$
\text { "roseicrissa. }
$$

Lagonosticta ruberrima.

Neisua myausie.

Serinus ictcrus.

Chrysomitris frontalis.
Mirafra zombr.

" tropicalis.

Anthus leggei.

Nectarinia erythrocerca.

Anthothreptes axillaris.

Cinnyris viridisplendens.

$$
\begin{aligned}
& \text { falkenstciui. } \\
& , \quad \text { igneiventris. } \\
& , \quad \text { reichenowi. }
\end{aligned}
$$

Zosterops jacksoni.

Anthoscopus roccatii.

'Telephonus emini.

Dryoscopus nandensis.

Cisticola carruthersi.

$$
\begin{array}{ll}
\text { " } & \text { emini. } \\
\text { belli. } \\
\text { " chubbi. } \\
\text { " nuchalis. }
\end{array}
$$

Bradypterus alfredi.

Calamocichla nilotica.

Apalis denti.

" jacksoni.

Lminia lepida.

Sylviella barakz.

$$
\begin{array}{ll} 
& \text { toroensis. } \\
\text { " leucophrys. }
\end{array}
$$


Burnesia melanops.

$\because$ reichenowi.

Turdus centralis.

Callene aquatorialis.

Neocossrphus pripectoralis.

Errthroproia hartlaubi.

Alethe corruthersi.

Crateropus kirki. (Ranging to the Zambesi R.)

Thurdinus prrrhopterus.

Bathmedonia jacksoni.

Ienocichla kikuruensis. $6500-10,000 \mathrm{ft}$. letissima,

Bleda moosnami.

Alseonar pumilus. $5000-10,000 \mathrm{ft}$. infulatus.

Muscicapa toroensis.

Chloropeta kenra. 6000-10.000 ft.

massaica.

.. grncilirostris.

Megabias requatorialis.

Trochocercus albonotatus. $6500-\$ 500 \mathrm{ft}$.

Terpsiphone suahelica.
Terpsiphone cmini.

Hirundo emini.

Psalidoprocue albiceps.

$$
\text { " mussaica. }
$$

Dendromus treniolimat.

Mesopicus rurenzori. 6500-5000 ft.

Dendropicus pocilolemus.

Tricholema ansorgei.

$$
\text { , radclifiei. }
$$

Grmnobucco cinereiceps.

Barbatula mfumbiri.

$$
\text { " centralis. }
$$

Trachrphonus elgoneusis.

Grmnoschizorhis leopoldi.

Turacus emini.

Caprimul@us rumenzori.

Irrisor jacksoni.

Melittophagus oreobates.

Eurrstomus rufobucealis.

Galactochrrsea emini.

Francolinus icterorhychus.

" mulemx.

The following 39 East-1frican species have been met with in the neighbourhoud of Rumenzori. some of the highland forms being found high up on the range-for instance. Turdus abyssinicus, which was met with from $6000 \mathrm{ft}$. nearls up to the snows:-

Yholidauges sharpei. S5̌Co ft.

Cinmamopterns tenuirostris. $10,000 \mathrm{ft}$.

l'coptera stuhimanni. $5000 \mathrm{ft.}$

Lamprotornis porphyropterus.

Heterhrohantes stuhlmani. $7000 \mathrm{f}$.

Hrphantornis intermedius.

Coliuspasser eques.

Cryptospiza salvadorii. $7000-8500 \mathrm{ft}$.

Lagonosticta rhodoparia.

Serinus kilimensis. sharpei.

Niectarinia kilimensis.

$$
\text { " melauognstra. }
$$

Cimurris sequatoriais.

$$
\text { ") microrhychus. }
$$

Laniarius erythrogaster.

Drroscopus minlaxcii.
Dryoscopus attinis. (?Also IV. Atrica.

Lanius intercedens.

Bradrpterus cimamomets. $6500-13,000 \mathrm{ft}$.

Apalis pulchella.

Geocichla piargie. 5000 - $9000 \mathrm{ft}$.

Turdus abrssinicus. 6000-13.000 ft.

Cossrpha heuglini.

Crateropus sharpei.

Phrllastrephus sucosus. 5000-9000 it.

Batis orientalis.

"puelli.

Dendronus mbicus.

Dendropieus zanzibari.

Lybius iequatorialis.

Colius atủnis.

Hapaloderma rittatum.

Rhinopomastus schalowi. 
Merops superciliosus. (Ranging to Mada- Buteo augur.

gascar \&c.)

Lissotis melanogaster.

Syrnium suahelicum.

Numida ptilorlonncha.

The following 8 species were met with only in the Eturi and East-Congo Forests :Spermospiza poliogenys.

Stizorhina vulpina.

Pholidornis denti.

Ersthrocercus congicus.

Alethe woosnami.

Trochocercus bedfordi.

Phyllanthus czarnikowi.

Gymnobucco sladeni.

The following 91 West-African species have been met with in the neighbourhood of Ruwenzori and in the Lake-district, chiefly in the Eturi and MIpanga Forests :-

Lamprocolius splendidus. $5000 \mathrm{ft}$.

Cisticola lateralis.

Dierurus atripennis.

Oriolus lietior.

Malimbus malimbicus.

$$
\text { , nigerrimus. }
$$

Heterhyphantes nigricollis.

Hyphantornis supereiliosus.

Pyrenestes ostrinus.

Pyromelana franciscana.

Spermestes cucullatus.

", poensis.

Nigrita fusconota.

, luteifrons.

" canicapilla.

Estrilda nonuula.

Anthothreptes tephrolæma.

Cyanomitra cyanolæma.

Cinnyris superbus.

" bouvieri.

" chloropygius.

Parus funereus.

Nilaus camerunensis.

Nicator chloris.

Laniarius lagdeni. (Rurenzori, $9000 \mathrm{ft}$., and Mufumbiro.)

" major.

Dryoscopus leucorhynchus.

Lanius mackinnoni.

Melocichla mentalis.

VOL. XIX.-PART IV. No. 35.-March. 1910.
" rufopileata.

Apalis caniceps.

,, binotata.

Srlviella carnapi?

" denti.

Camaroptera superciliaris. (Met with at Mawambi.)

Stiphrornis xanthogaster. (Met with at Nlawambi.)

Hylia prasina.

Burnesia bairdi.

Cossypha bartteloti.

$\because \quad$ melanonota.

Erythropygia ruficauda.

Alethe poliothoras.

Myrmecocichla nigra.

Iacrosphenus flavicans.

Turdinus fulvescens.

„ cerviniventris.

Criniger calurus.

Xenocichla leucoliema.

Andropadus indicator.

„ virens.

, gracilis.

" curvirostris.

, latirostris.

Phyllastrephus icterinus.

Ixonotus guttatus. (Extending to Miambi,

Eturi $\mathrm{K}_{\text {, and }}$ Ponthierville, Upper Cungo.)

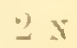


Campophaga petiti.

Graucalus azureus.

Alseonax epulatus.

" fantisiensis.

" comitatus.

Diaphorophyia castanea. " jamesoni.

Smithornis camerunensis. , rufolateralis.

" sharpei.

Artomyias fulinginosa.

Terpsiphone duchaillui.

Elminia longicauda.

Hirundo gordoni.

Psalidoprocne nitens.

Dendromus caroli.

Mesopicus ellioti.

Dendropicus lafresnayi.

Indicator cxilis.

Corythæola cristata.

Musophaga rossæ.

Centropus occidentalis.

Ceuthmochares aëreus.

Cercococcyx mechowi.

Chrysococcyx flavigularis.

Ceratogymna atrata.

Lophoceros fasciatus.

Halcyon badius.

Myioceyx ruficeps. (Avakubi.)

Agapornis pullarius.

Poocephalus aubryanus. (Mawambi)

Vinago calva.

Columba unicincta.

Francolinus schuetti.

Pternistes cranchi.

The following 8 species known to occur in Angola were also met with in the Ruwenzori District:-

Estrilda paludicola.

Parus insignis.

Pycnonotus tricolor.

Terpsiphone ignea.

Cosmetornis vexillarius.

Bycanistes subquadratus.

Halcyon pallidiventris.

Poocephalus reichenowi.

The following 4 South-African forms range north to the Ruwenzori District:-

Cinnyris mariquensis.

Schenicola apicalis.

Irrisor viridis.

Turnix nana.

The following 94 widely distributed African species were met with in the neighbourhood of Ruwenzori; their range in other parts of Africa is indicated by the letters E. (=East), N.E. (= North-east), S.E. (= South-east), W. (= West), N.W. (= North-west), S. (=South), S.W. (=South-west), and 'T. A. (='Tropical Africa):-

Corvultur albicollis . . . . . E.\& S. (Met with up to 14,000 ft.)

Pholidauges verreauxi. . . . . . L., W., \& S.

Dicrurus afer . . . . . . . E., W., \& S.

Oriolus rolleti. . . . . . . . . L. \& s..1\%.

Amaplectes melanotis . . . . . . E, N.E., X.W., S S.W.

Hyphantornis xanthops . . . . . . L., W... S.

Sitagra ocularia . . . . . . H., W., \& S.

" luteola . . . . . . N.t. N.W.

Quelca quelear . . . . . . . W. \& s.

Pyromelana Hammiceps . . . . E.\& W. 
Pyromelana xanthomelas . . . . E. \& S.W.

Coliuspasser ardens . . . . . . L., S.W., \& S.

Sporæginthus subflavus . . . . . . T. 1 .

Vidua serena . . . . . . . E., W., \& S.

Passer diffusus . . . . . . . . . L., W., \& $\$$.

Emberiza flaviventris . . . . . L., W., \& $\$$

Motacilla vidua . . . . . . . T. A.

" longicauda . . . . . . 'I'. A.

Anthus pyrrhonotus . . . . . . L.,W., \& S.

Macronyx croceus . . . . . . E., WV., \& S.

Nectarinia cupreonitens . . . . E. \& W.

Anthothreptes zambesiana . . . . E.\& W.

Cyanomitra ragazzii . . . . . E. \& W.

Cinnyris cupreus . . . . . . . E. \& W.

Telephonus erythropterus . . . . W. \& S.

$"$ minutus . . . . . . W.\& N.E.

Laniarius similis . . . . . . E., N.W., \& S.

Lanius humeralis . . . . . . E., ?W., \& S.

Cisticola rufa . . . . . . . . IV. \& S.L.

, terrestris . . . . . E. $\mathrm{d} s$.

" crythrops . . . . . E. \& W.

, lugubris . . . . . . L., W., \& S.

" strangei . . . . . . IV. \& S

Camaroptera griseoviridis . . . . E. \& W.

Prinia mystacea . . . . . . . . 'T. A.

Pratincola salax . . . . . . E. \& WV.

Campophaga nigra . . . . . . . E., W', \& S.

Graucalus cresius. . . . . . . E. \& S.

Melænornis pammelina . . . . N.E.\& N.W.

Bradyornis murinus. . . . . . E., S.W., \& S.

Parisoma plumbeum . . . . . . W. \& S.

Platystira cyanea. . . . . . . L. \& W.

Cotile cincta . . . . . . . . N.L., W., \& S.

" rufigula . . . . . . E., N.E., \& N.W.

Mesopicus pœocephalus . . . . N.E.\& N.W.

Indicator variegatus . . . . . . E. \& S.

" minor. . . . . . E. \& S.

Centropus superciliosus. . . . . . E. \& S.W.

Coccystes cafer . . . . . . . . T. 1.

" jacobinus. . . . . T. A.

Cuculus solitarius . . . . . . . . 'T. A.

Chrysococcyx cupreus . . . . . . T. $\Lambda$.

$"$ klaasi . . . . . 'T. $\Lambda$.

Metallococcyx smaragdineus . . . W. \& S. 


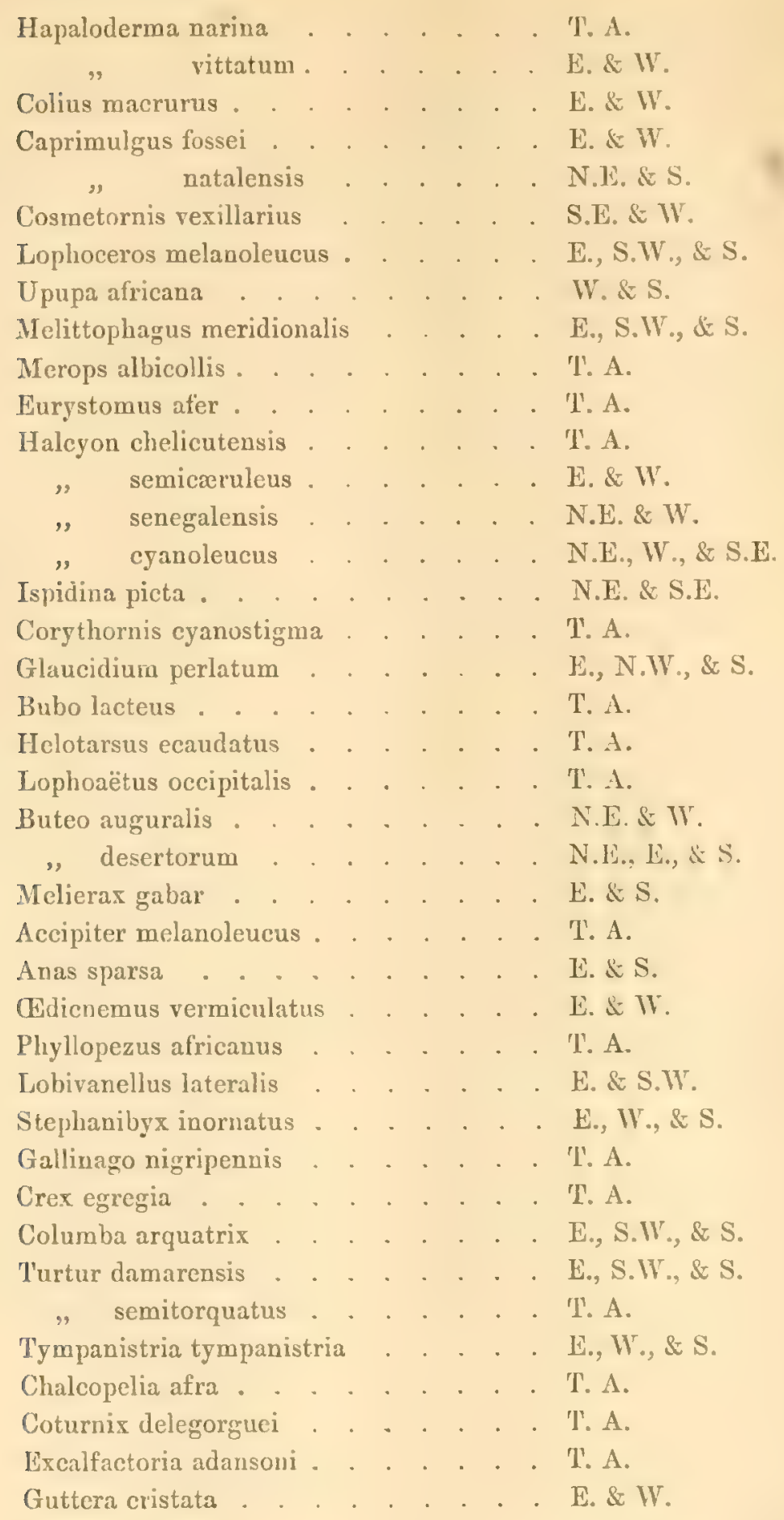


The range of the following 19 species which occur in the Ruwensori District extends beyond Africa:-

Motacilla flava.

Anthus trivialis.

Sylvia atricapilla. , hortensis.

Phylloscopus eversmanni. , trochilus.

Pratincola rubetra.

Merops apiaster. , persicus.

Ceryle rudis.
Elanus cæruleus.

Milvus ægyptius.

Circus macrurus.

Querquedula circia.

Sarcidiornis melanonota.

Glareola pratincola.

Totanus ochropus.

Crex crex.

'Jurtur senegalensis.

The species represented in the present collection may therefore be classifier as follows:-

Number of species.

Species peculiar to the Ruwenzori range . . . . . . . . . . . 20

Species found on the Ruwenzori range and also on the Mufumbiro

Volcanoes . . . . . . . . . . . . 6

Species confined to the Ruwenzori District and to the great central chain

of Lakes .. . . . . . . . . . . . . . . . 96

East-African species ranging to the Ruwenzori District . . . . . . . 39

Species peculiar to the Eturi and E. Congo Forests . . . . . . . . 8

West-African species ranging to the Ruwenzori District . . . . . . 91

Angolan species rauging to the Ruwenzori District . . . . . . . . 8

South-African species ranging north to the Ruwenzori District . . . . 4

Widely distributed species found in the Ruwenzori District . . . . . 94

Species whose range extends beyond Africa, found in the Ruwenzori

District . . . . . . . . . . . . . 19

Total. . . . 38:

The following is a list of the 27 new species procured by the Ruwenzori Expedition :-

Malimbus fagani . . . . Grant, Bull. B. O. C. xxi. p. 15 (1907).

Cimnamopteryx mpangre . . . ",$\quad$ xxi. p. 15 (1907).

Hyphantornis feminina. . . , , ",$\quad$ xxi. p. 15 (1907).

Spermospiza poliogenys. . . .,$\quad$ xix. p. $32(1906)$.

Pyromelana crassirostris . . . " " " $\quad$ xxi.p. 14 (1907).

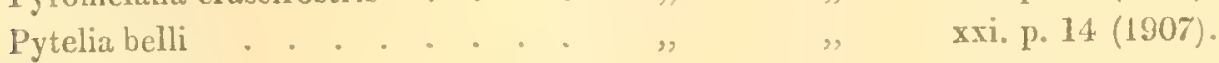

Anthus leggei . . . . . , " " xix. p. 26 (1906).

Nectarinia dartmouthi ..... , , ", xvi. p. 117 (1906).

Pholidornis denti . . . .,$\quad$ xix. p. 41 (1907).

Cisticola carruthersi . . . . ,,$\quad$ xxiii. p. 94 (1909).

" belli ...... ",$\quad$ xxi. p. 71 (1908). 


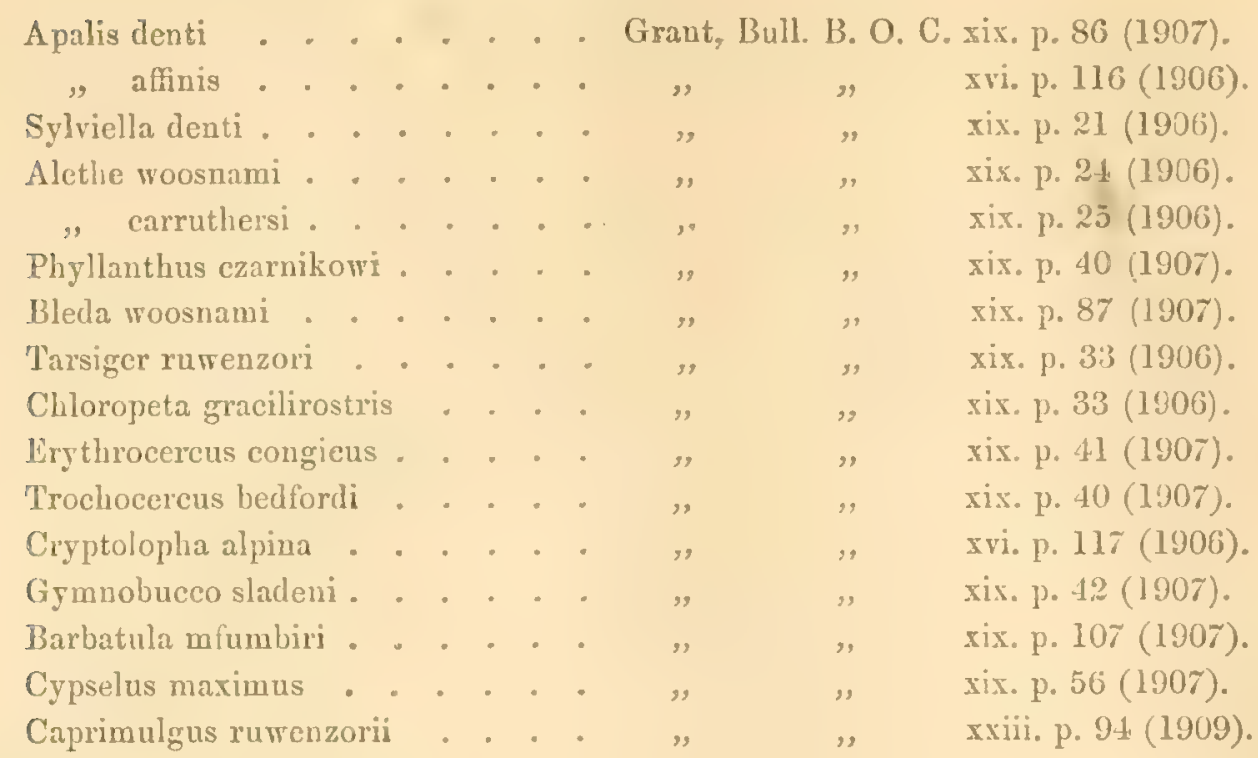

The following new species from Sierra Leone is also described in the present work:-

Cinnyris liempi Grant, see p. 329.

Throughout this Report I have quoted Dr. Reichenow's 'Die Vögel Afrikas,' which is the only descriptive work dealing with the Birds of Africa as a whole. 'The value of this great work is generally admitted, but its scientific usefulness is in many respects greatly lessened owing to the way in which the writings of other ornithologists have been treated or even ignored by the author. In many instances perfectly distinct and well-characterised species, which have not been examined by Dr. Reichenow, are suppressed and placed in the synonymy of some more or less allied form, while quite a number of supposed geographical races described at length by the author appear to have no real existence.

Though much of the information contained in the 'Vögel Afrikas' is derived from the twenty-seven rolumes of the 'Catalogue of the Birds in the British Museum,' that great work is only referred to in the case of the new species of African birds described therein. On the other hand, some comparatively useless works are quoted in the synonymy.

In the lists of specimens procured by the Expedition the letter "d." placed over some of the collectors' numbers indicates that those examples were duplicates not retained in the series kept for the British Museum. The initials within the brackets signify the name of the collector, thus:-R. E. D. (=R. E. Dent); D. C. (=Douglas Carruthers); G. L. (=Hon. Gerald Legge) and R. B. W. (=R. B. Woosnam).

The field-notes and observations by Mr. Woosnam on the local range of the various species will be found in square brackets with his initials appended to them. 


\section{Family C ORVID}

\section{Corvultur albicolis (Lath.).}

Corvultur albicollis Sharpe, P. Z. S. 1900, p. 602 [Kenia]; Hartert, Nov. Zool. vii. p. 38 (1900) [Toro]; Reich. Vög. Afr. ï. p. 640 (1903).

a. ‥ Mubuku Valley, E. Ruwenzori, $12,500 \mathrm{ft.,} 16 \mathrm{th}$ Feb. [No. 158. R. E. D.]

Iris dark brown; bill black, white at the tip; feet black.

This Raren was met with by the Mackinder Expedition on Mount Kenia up to an elevation of $10,000 \mathrm{ft}$.

[The White-necked Raven was seen on Ruwenzori up to an elevation of $14,000 \mathrm{ft}$. A pair had a nest in a cliff overhanging our camp at $12,500 \mathrm{ft}$., but the species was not very common at these altitudes and was most numerous below $7000 \mathrm{ft} .-R$. B. W.

\section{Family STURNADE.}

\section{Photidauges verreauxi Bocage.}

Pholidauges verreauxi Jackson, Ibis, 1899, p. 589 [Njemps, Eldoma Ravine].

Cinnyricinclus verreauxi Reich. Vög. Afr. ii. p. 680 (1903); Jackson, Ibis, 1906, p. $56 !$ [Ertebbe; Toro].

a. $\delta$ imm. 60 miles N. of Fort Beni, Semliki Valley, 3500 ft., 16th Aug. [No. 1785. D.C.]

Iris pale yellow; bill and feet black.

This example of Verreaux's Glossy Starling is in an interesting stage of plumage, showing the change in the contour feathers of the upperparts from the immature to the adult. Some of the feathers of the back are brown, others brilliant metallic purple, and many of those on the crown and nape are still in quill.

[A single specimen obtained on the eastern edge of the Eturi Forest, near Irumu. $-R, B . W$.

\section{Pholidauges silarpei Jackson.}

Pholidauges sharpei Jackson, Tbis, 1899, pp. 303, 590, pl. xii. [Nandi, Iildoma Ravine].

Pholia himundinea, Reich. Orn. MLonatsb. viii. p. 99 (1900).

Plolia sharpei Reich. Vüg. Afr. ii. p. 682 (1903).

a. ․ Mubuku Valley, R. Ruwenzori, $7000 \mathrm{ft} ., 22 \mathrm{nd}$ Jan. [No. 3125. R. B.W.]

b, c. $\delta^{\pi}$. . " " $\quad 9000 \mathrm{ft}$. 3rd March. [Nos. 180, 18\%.

R. E. D.]

Iris bright yellow in the male, yellowish-green or greenish-brown in the female bill and feet black.

This rare Starling was described by Mr. Jackson from specimens procured by him at the Eldoma Ravine in 1897. It has also been recorded by Dr. Reichenow from the north of Lake Nyasa, and was described by him as a new genus of Flycatchers' 
The pair collected by Mr. R. E. Dent were said to be breeding. As suggested by Dr. Sharpe ( $c f$. ' Ibis,' 1899 , p. 590), the adult female resembles the male in plumage, but has the belly, \&c., of a paler cinnamon-rufous; it is, moreover, smaller.

'The measurements of the above specimens are as follows :-

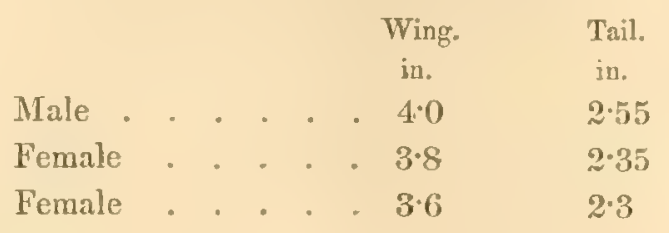

[Sharpe's Starling was occasionally seen on the east side of Ruwenzori from an altitude of $6500 \mathrm{ft}$. up to $8500 \mathrm{ft}$., but was distinctly rare. Parties were sometimes seen flying in company with the flocks of Cinnamopterus tenvirostris, but whether this is the usual custom of the species it is difficult to say. $-R . B . W$.

IaAmRocolius SPlendidus (Vieill.).

Lamprocolius splendidus Rcich. Vög. Afr. ii. p. 692 (1903).

Lamprocolius splendidus glaucovirens Elliot; Hartert, Nov. Zool. vii. p. 39 (1900) [Fort Beni]; Reich. Vög. Afr. ii. p. 693 (1903).

a, b. ठ ․ 60 miles W. of Entebbe, 3500-3700 ft., 29 th Nov. [Nos. 1016. D. C.; 2011. G. L.]

c, d. 우 ㅇ․ Fort Beni, Semliki Valley, 3000 ft., 23 rd \& 24 th July. [Nos. 2431. (i. L. ; i.).lli. R. B. H.]

Adult male and female. Iris white; bill and feet black.

Both pairs of this extremely beautiful Glossy Starling are apparently in freshly moulted plumage; but the birds killed in July have the tips of the tail-feathers slightly worn.

There can be little doubt that $L$ : glaucovirens Elliot is founded on a male example of L. splendidus (Vieill.). Owing, no doubt, to the lack of specimens in which the sex had been ascertained, Dr. Sharpe (Cat. Birds B. M. xiii. pp. 172, 173) considered the sexes to represent distinct species. The specimens referred by him to $L$. splendidus with the "throat bluish-purple and the head of the same metallic-green as the mantle" are all females; while those with the "throat reddish-purple and the head steel-blue or steel-green, contrasting with the oil-green of the mantle," and named $L$.glaucovirens, are all males.

The measurements of the four specimens procured by the Expedition are as follows:-

$\begin{array}{ccc} & \begin{array}{c}\text { Wing. } \\ \text { in. } \\ \text { Males . . . . } 6 \cdot 1-6 \cdot 2\end{array} & \begin{array}{c}\text { Tail. } \\ \text { in. } \\ 4: 6-4 \cdot 85\end{array} \\ \text { Females . . . } 5 \cdot 6-5 \cdot 95 & 4 \cdot 4-4 \cdot 5\end{array}$

['This handsome Glossy Starling was seen throughout the journey from Victoria 
Nyanza to the edge of the Eturi Forest. It was not found on Ruwenzori above an altitude of $5000 \mathrm{ft} .-R . B . W$.]

Cinkamopterus tenutrostris (Rüpp.).

Cimnamopterus tenuirostris Reich. Vög. Afr. ii. p. 703 (1903); Jackson, Ibis, 1906, p. 569 [Ruwenzori]; Sharpe, P. Z.S. 1900, p. 602 [Kenia].

$a-l$. o $q$ et $q$ imm. Mubuku Valley, E. Ruwenzori, 6000-10,000 ft., 6th-28th Jan. [Nos. 100.R. E. D. ; 1179. D. C.; 2063. G. L.; 3129.R. B.W.]

e-g. ơ ㅇ․ Mubuku Valley, E. Ruwenzori, 9000-10,000 ft., 21st-25th Feb. [Nos. 165.R. E. D. ; 1268, 1269. D.C.]

$h-s$. of $q$ et $\delta$ imm. Mubuku Valley, E. Ruwenzori, 5000-9000 ft., 3rd-20th March. [Nos: 212. R. E. D.; 1283, 1285, 1308, 1355, 1386, 1387. D. C.; 2220 , d. d. $\left.2223,2224,2225 . G . L_{0}\right]$

Iris dark hazel-brown or dark brown; bill and feet black. 'The colours of three immature birds are similar to those of the adult.

In my notes on the birds collected in Sokotra ( $c f$. Nat. Hist. Sokotra and Abd-el-Kuri, p. 23) I pointed out the interesting fact that in the young female of the Starling Amydrus blythi the head and neck are black like those of the male parent, the grey plumage of the adult female being subsequently assumed. 'The same peculiarity is noticeable in the present species. Immature birds, both male and female, resemble the male parent in lacking all trace of grey edgings to the feathers; but the whole plumage is much less glossy. In the adult male the feathers of the back and underparts below the throat are black widely margined with purplish-bronze; in the young the feathers of the back are more narrowly edged with bluish-purple and the underparts are dull black with scarcely any gloss. The tail in the immature bird is shorter than in the adult.

\begin{tabular}{|c|c|c|c|}
\hline & & & $\begin{array}{l}\text { Wing. } \\
\text { in. }\end{array}$ \\
\hline Adult $\sigma^{*}$ & . & . & . 6.3 \\
\hline , $\quad$ 인 & . & . & . $5 \cdot 9$ \\
\hline Immature $\delta$ & . & . & . $5 \cdot 9$ \\
\hline q & & & $.5 \cdot 7$ \\
\hline
\end{tabular}

[These Red-winged Starlings were plentiful on Ruwenzori from 6500 to 10,000 ft. They were usually seen in large flocks flying up or down the valleys; great numbers used to roost in the tall trees and cliffs around the camp at 10,000 ft., and their shrill call was one of the few bird-notes that was to be heard above $9000 \mathrm{ft}$. They appeared to feed largely upon the berries of the Pedocarpus (P. milanjiana). $-R, B . W$.]

VOL. XIX.-PART IV. No. 36.-March, 1910. 
l'aoptera stuhlmanni Reichenow.

Stilbopsar stuhlmanni Reich. Vög. Afr. ii. p. 706 (1903).

a. + imm. Mpanga Forest, Fort Portal, $5000 \mathrm{ft}$, 17 th Sept. [No. 528. R. E. D.]

Iris yellow; bill and feet black.

This specimen, which is no doubt immature, has the plumage mostly black with very little of the oil-green gloss on the underparts which is characteristic of the adult female; it is also a somewhat smaller bird, the tail especially being shorter.

Adult female. Wing 3.9 inches; tail 3.05 .

Immature female. Wing 3.75 inches; tail 2.4 .

['l'his small Red-winged Starling was shot among the tops of high trees. $-R . B . H$.]

\section{LAMPROTORNIS PORPHYROPTERUS Rüpp.}

Lamprotornis purpuropterus Reich. Vög. Afr. ii. p. 710 (1903).

Lamprotornis porphyropterus Jackson, Ibis, 1906, p. 568 [Toro; Ankoli]; Grant, Ibis, 1902, p. 401,1907 , p. 580.

$a, b$. o $^{\circ}$. 70 miles W. of Entebbe, $3700 \mathrm{ft}$., $30 \mathrm{th}$ Nov. \& 1st Dec. [Nos. 19. R. E. D.; 3019. R. B.W.]

c. ․ 100 miles W. of Entebbe, $4000 \mathrm{ft}$, 7 th Dec. [No. 2022. G. L.]

d. o. 120 miles W. of Entebbe, $4200 \mathrm{ft}$., 8th Dec. [No. 1051. D.C.]

e. of. Mokia, S.E. Ruwenzori, $3400 \mathrm{ft}, 24$ th April. [No. 1427. D. C.]

f.g. o. " " " $\quad$ th \& 19th May. [Nos. 34t. R. E. D.; d.

2334. G. L.]

h, i. o. Mokia, S.E. Ruwenzori, $3400 \mathrm{ft.}, 16$ th \& 17 th June. [Nos. 1637. D. C.; 2404. G. L.]

Iris white or very pale yellow; bill and feet black.

The characters by which this shorter-tailed form of the Purple-winged Glossy Starling is distinguished from L. aneocephalus Heugl. have already been pointed out at some length in my papers in the 'Ibis,' quoted above.

The measurements of the above series are as follows:-

$\begin{array}{ccc} & & \text { Wing. } \\ \text { in. } & \text { Tril. } \\ \text { in. } \\ \text { Males . . . . } 5 \cdot 9-6 \cdot 1 & 5 \cdot 55-5 \cdot 8 \\ \text { Females . . . . } 5 \cdot 1-5 \cdot 3 & 4 \cdot 6-5 \cdot 0\end{array}$

In freshly moulted examples, such as No. 344, killed on the 19th of May, the feathers of the back and breast are purplish-green; in worn examples, such as specimen 1051, killed on the 8th of December, the feathers of these parts are mostly deep violet, while the exposed portions of many of the quills are brownish-black and entirely lack the metallic gloss. 
[This Glossy Starling was seen throughout the journey from Entebbe to Ruwenzori ; it was not observed on the mountains, but was not uncommon in the acacia-country at the south end of the range. $-R . B . W$.

\section{Family D ICR UR I D}

Dicrurus afer (Licht.).

Dicrurus afer Reich. Vög. Afr. ii.p. 646 (1903).

Buchanga afra Jackson, Ibis, 1906, p. 567 [Toro].

a. ․ 60 miles W. of Entebbe, $3700 \mathrm{ft.,} 29$ th Nov. [No. 17. R. E. D.]

b. o 100 miles W. of Entebbe, $4100 \mathrm{ft}$., 6th Dec. [No. 1035. D. C.]

c. o. Mokia, S.E. Ruwenzori, 3400 ft., 30th April. [No. 260. R. E. D.]

$d-g$. ot et imm. Mokia, S.E. Ruwenzori, $3 \pm 00 \mathrm{ft}$, 50th-22nd May. [Nos. 289, 308, $348 . R . E . D . ; 1600$. D.C.]

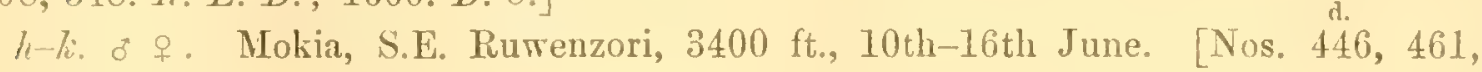
464.R.E. D.]

Iris red, claret or reddish-brown in adults, hazel or brown in immature examples; bill and feet black.

['This Drongo was seen near Entebbe and along the eastern side of Ruwenzori, as well as in the upper part of the Semliki Valley.-R. B. W.]

\section{Dicrurus atripennis Swains.}

Dicrurus atripennis Reich. Vög. Afr. ii. p. 651 (1903).

a, b. q. Irumu, Eturi Forest, 3000 ft., 16th \& 21st Oct. [Nos. 569. R. E. D.; 3639. R. B. W.]

Iris crimson or claret-colour; bill and feet black.

'The presence of this West-African Drongo in the Eturi Forest is of interest, as hitherto it has only been recorded as occurring between Gambia and the Gaboon. Both specimens are in freshly moulted plumage, most of the tail-feathers in No. 3639 being only partially grown.

The two females measure respectively:-

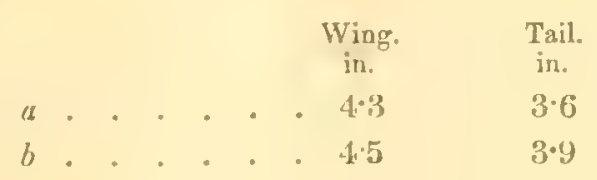

[Not uncommon in the forests around Fort Beni, Irumu, and Mawambi. $R . B_{0}, W$. ] 
Family ORIOLID

ORIOLUS ROLLETI Salvadori.

Oriolus rolleti Jackson, Ibis, 1899, p. 595 [Entebbe, Kamassia, Eldoma Ravine, Nandi]; 1906, p. 568 [Toro].

Oriolus larvatus rolleti Reich. Vög. Afr. ii. p. 659 (1903).

a. o . 120 miles W. of Entebbe, $4200 \mathrm{ft} ., 8$ th Dec. [No. 1046. D. C.]

b-e. ơ ㅇ. Mokia, S.E. Ruwenzori, $3400 \mathrm{ft} ., 2$ d-18th May. [No.310. R. E. D.; d.

1477, 1534, 1584. D. C.]

f. \&. Mokia, S.E. Ruwenzori, $3400 \mathrm{ft}$, 19th June. [No. 1646. D. C.]

Iris light red, red, or dark red; bill flesh-colour, pink, reddish-brown, or brown; feet grey, dark grey, bluish-grey, or black.

The male (No. 310) shot on the 10th May is marked by Mr. Dent as being a breedingubird. It appears to be perfectly adult, but shows scarcely a trace of any yellow colour on the hind-neck, which is only a little brighter than the back. A female (No. 1534) shot on the same date has the yellow collar on the hind-neck well developed (as is the case in all the other birds both male and female), and the feathers of both the mantle and the breast have narrow dusky shaft-streaks.

[Rollet's Oriole was obtained near Entebbe and was seen occasionally throughout the journey to Ruwenzori. It was not uncommon among the taller acacia-trees on the plains around the south end.- $R . B . W$.]

\section{Ortolus Lation Shatpe.}

Oriolus lretior Sharpe, Bull. B. O. C. vii. p. xvii (1897); id. Ibis, 1898, p. 155 [Gaboon]; Hartert, Nov. Zool. vii. p. 39 (1900) [Fort Beni].

Oriolus larvatus lactior Reich. Vög. Afr. ii. p. 661 (1903).

a. o . 50 miles north of Fort Beni, Semliki Valley, $3500 \mathrm{ft.,}$ 15th Aug. [No. 1783. D.C.]

b. o imm. Mawambi, E. Congo Forest, $3000 \mathrm{ft}, 22 \mathrm{nd}$ Oct. [No.3641.R. B. W.]

c. ․ Mpanga Forest, Fort Portal, 5000 ft., 14th Sept. [No. 3564. R. B.W.]

Male. Iris dark red; bill pink; feet dark grey.

Female. Iris dark chestnut; bill reddish-brown; feet grey.

Immature female. Iris light brown; bill dark brown; feet gres.

This Oriole was originally described in the briefest manner from a specimen from Gaboon. It also inhabits the Cameroon district, and has been procured by Dr. Ansorge near Fort Beni.

A marked difference in plumage between the sexes of this species has hitherto been overlooked and is worth recording. The male, besides having a much wider and more brilliant yellow collar which extends over the mantle, differs from the female in 
having the inner webs of the innermost secondary-quills widely margined with deep black, contrasting sharply with the olive-green portion which lies next to the shaft. In the female the yellow collar is paler and much narrower (much as in males of O. brachyrhynchus), and the inner webs of the innermost secondaries are olive-green, gradually shading into dusky olive towards the margin.

The nearly allied 0 . brachyrhynchus, which ranges from Sierra Leone to Togo, appears to show the same sexual differences as regards the coloration of the innermost secondary-quills, but in none of the specimens in the British Museum Collection has the sex been determined.

[This Yellow-collared Oriole appears to be plentiful in the Congo Forest. It was not often seen, but a clear mellow note, presumably of this species, was often heard from among the tree-tops. It was plentiful in the Mpanga Forest, east of Ruwenzori. $-R . B . W$.

\section{Oriolus percivali Grant.}

Oriolus larvatus Sharpe, Ibis, 1891, p. 243 [part., nos. 301, 324, Elgon].

Oriolus rolleti Jackson, Ibis, 1899, p. 595 [part., nos. 1226, 1228, 1249, Nandi].

Oriolus percivali Grant, Bull. B. O. C. xiv. p. 18 (1903); Reich. Vög. Afr。 iii. App.p. 836 (1905).

a. q. Mpanga Forest, Fort Portal, $5000 \mathrm{ft.,}$ 15th Sept. [No. 520. R. E. D.]

Tris dark crimson; bill "bone"-colour; feet slate-grey.

The type of this species was procured by Mr. A. B. Percival in the Kikuyu Forest, and there are specimens in the Jackson Collection from Mt. Elgon and Nandi, which are referred to in the synonymy given above.

The present specimen, a female, differs only from the type in its somewhat smaller size: wing $5 \cdot 2$ inches; tail $3 \cdot 5$.

\section{Family PLOCEID E.}

\section{Milimbes centralis Reichenow.}

Malimbus rubricollis centralis Reich. Vög. Afr. iii. p. 21 (1904).

Malimbus centralis Jackson, Ibis, 1906, p. 567 [Kibera, Toro].

a, b. o. Mpanga Forest, Fort Portal, $5000 \mathrm{ft}$. , 17th \& 22nd Sept. [Nos. 527. R.E. D.; 3606. R. B.W.]

Iris dark brown or dark crimson; bill and feet black.

This is merely a slightly smaller form of $M$. rubricollis (Swains.), the bill, as pointed out by Dr. Reichenow, being much more slender than in the typical West-African form.

[Reichenow's Malimbe was plentiful in the Mpanga Forest. It was ouly seen among the tops of the tall trees and never among the undergrowth. $-R . B . W$.] 
Malimbus malimbicus (Daud.).

Malimbus malimbicus Reich. Vög. Afr. iii. p. 21 (1904); Shelley, B. Afr. iv. p. 349 (1905).

a. ठ . Fort Beni, Semliki Valley, $3000 \mathrm{ft}$, 24th July. [No. 1756. I. C.]

3. \&. 30 miles N.W. of Fort Beni, 3000 ft., 12th Ang. [No. 2448. G. L.]

c. उ. Irumu, Eturi Forest, $3000 \mathrm{ft} ., 16$ th Oct. [No.56S. R. E. D.]

Iris dark brown or dark hazel; bill and feet black.

[The Crested Malimbe was found in the Congo Forest, where it frequented the tops of tall trees. $-R . B . I V$.

Malimbes fagani Grant. (Plate X. fig. 1, o* .)

Malimb̈us fagani Grant, Bull. B. O. C. xxi.p. 15 (1907).

". *. Fort Beni, Semliki Valley, $3000 \mathrm{ft} ., 21$ st July. [No. 3508. R. B.W. Type of the species.]

This species is very closely allied to $M$. erythrogaster Reich., but differs in having a smaller bill, the red on the crown and underparts more intense, and the flanks, thighs, and under tail-coverts mostly black, some of the feathers being more or less mixed with red. Iris dark brown; bill black; feet brown. 'lotal length 6 inches; culmen 0.9 ; wing $3 \cdot 6$; tail 2.05 ; tarsus 0.9 .

The type of this species, a fine adult male specimen, has been compared with male and female examples of $M$. erythrogaster Reichenow, collected by Dr. W. J. Ansorge in Southern Nigerin, and kindly sent me for examination from the Tring Museum. These agree well with Dr. Reichenow's description and figure of the types of M. erythrogaster, which were procured by Dr. Zenker at Jaunde, Cameroon.

Though the differences mentioned above are not very pronounced, they seem to indicate that the specimen from Fort Beni represents a distinct form.

Malmbus nigerrimus (Vieill.).

Ploceus nigerrimus Reich. Vög. Afr. iii. p. 50 (1904).

Melanopteryx nigerrima Shelley, B. Afr. iv. p. 362 (1905); Jackson, Ibis, 1906, p. 566 [Toro]. Malimbus nigerrimus Grant, Ibis, 1908, p. 278 [Upper Congo].

r-e. of et o imm. Fort Beni, Semliki Valley, \$000 ft., 19th-24th July. [Nos. 482. R. E. D.; 1726. D. C.; 2421, 2434, 2435. G. L. ]

f. o. 40 miles N.W. of Fort Beni, 3000 ft., 13th Aug. [No. 2449. G. L.]

y, h. of Mpanga Forest, Fort Portal, 5000 ft., 14th-17th Sept. [Nos. 522. li. E. II.; 356:3. Li. li. II.]

Adult male. Iris yellow or light yellow; bill black; feet brown.

Adult female. Iris dirty yellow; bill dark horn-colour; feet brown.

[Vieillot's Black Malimbe was very numerous in the clearings in the Congo Forest and a few were also seen in the Mpanga Forest, east of Ruwenzori. It was nesting in 
huge colonies, and in one place a tall tree had at least 100 nests of this bird hanging from its branches. $\left.-R . B . W^{\top}.\right]$

Axaplectes melanotis (Lafr.).

Anaplectes melanotis Reich. Vög. Afr. iii. p. 26 (1901); Shelley, B. Afr. iv. p. 338 (1905) [part.]; Grant, Ibis, 1908, p. 276 [S.W. Uganda].

a, b. o ․ Mokia, S.E. Ruvenzori, $3400 \mathrm{ft}$, 26th \& 30 th April. [Nos. 244, 2il. I. E. E. I).

c, d. o ․ Nokia, S.E. Ruwenzori, $3400 \mathrm{ft}$, 5th \& 31st. May. [Nos. 40hi, R. E. D.; 1500. D.C.]

e. o. Mokia, S.E. Ruwenzori, $3400 \mathrm{ft}$., 6th June. [No. 3457. R. B.W.]

Adult male. Iris reddish-brown, chocolate, or hazel; bill scarlet; feet brown or mauve.

Adult female. Iris dark brown or hazel; bill red; feet brown or light brown.

The female (b) shot on the 30 th of April is in very worn plumage, the feathers, especially those of the breast, having the terminal half more or less worn oft. All three males are moulting, and many of the scarlet feathers of the head and throat are being renewed.

[A few examples of the Red-ringed Anaplectes were found in the acacia-forest on the plains round the south end of Rurrenzori, but the species was by no means common.-R.B. $[W$.

Sycobrotus Meatalis (Hartl.).

Ploceus mentalis Reich. Vög. Afro iii. p. 35 (1904).

Sycobrotus mentalis Shelley, B. Afr. ir. p. 371 (1905).

Sycubrotus nandensis Jackison, Ibis, 1899, p. 615.

a. 8*. Mpanga Forest, Fort Portal, 5000 ft., 15th Sept. [No. 516. R. E D.]

Iris crimson; bill slate-blue; feet flesh-colour.

This bird is no doubt a male of $S$. mentalis (Hartl.) and closely resembles the female iype of S. nandensis Jackson, but the underparts are much brighter yellow. especially on the chest and breast. As in the type of $S$. nandensis, there is an interrupted half-hidden line of black spots down the middle of the chest, formed by some of the median feathers having one web partially black; the grey back and upperparts ar slightly paler and have a distinct yellowish tinge. 'lotal length 5.5 inches; wing 3.3 ; tail 2.05 ; tarsus 0.85 .

Dr. Hartert has kindly forwarded from the Tring Museum the type of $S$. entalis (Hartl.), procured by Emin at Buguera (Wadelai); also four examples collecter by Herr R. Grauer in the Mpanga Forest. These latter show considerable variation as regards the amount of yellow on the throat, one having the throat almost entirely 
black, while another has the middle of the throat mostly yellow and closely resembles the type of S. mentalis. There can be little doubt that the type of S. nandensis is a female of the present species, and that the name should be added to the synonymy.

In the type of $S$. mentalis (a male) the wing measures 3.4 inches; in five males from the Mpanga Forest the wing measures $3 \cdot 1-3 \cdot 3$; and in the type of $S$. nandensis (a female) it measures 3.2 .

[The Black-chinned Grey-backed Weaver was not uncommon in the Mpanga Forest, and was also observed in the Congo Forest. $-R . B . W$.

\section{Hererimphantes stuhlyany Reich.}

Symplectes stuhlmanni Hartert, Nov. Zool. vii. p. 42 (1900) [Uganda; Toro; Unyoro].

Ploceus stuhlmanni Reich. Vög. Afr. iii. p. 40, pl. xii. fig. 3 (1904).

Othyphantes stuhlmanni Shelley, B. Afr. iv. p. 453 (1905); Jackson, Ibis, 1906, p. 566 [Toro].

a, b. of et o imm. 130 miles W. of Entebbe, 4000-4200 ft., 10th Dec. [Nos. 45. l. E. D.; s051. R. B. II.]

c. o. Mubuku Valley, E. Ruwenzori, $6000 \mathrm{ft} ., 29$ th Dec. [No. 55. R. E. D.]

d,e. o. $, \quad, \quad$, 5th \& 6th Jan. [Nos. 1105. I). C. : $30 \%$ '. R. R. II.]

$f-i$. o 후 et o imm. Mubuku Valley, E. Ruwenzori, $6000 \mathrm{ft}$., 1st-24th Feb. [Nos. 139. R. E. D.; 1266. D.C.; 2137, 2169.G. L.]

$k-p$. of of et $q$ imm. Mubuku Valley, E. Ruweuzori, 5000-6000 ft., 14th-25̃th March. [Nos. 2196, 2197, 2222, 2230, 2.234, 2247. G. L. $]$

q. ․ Mokia, S.E. Ruwenzori, $3400 \mathrm{ft} ., 11$ th May. [No. 1546. D. C.]

$r$. ․ $\quad$ " $\quad$ 29th June. [No. 1712. D. C.]

Adult male and female. Iris white or pale yellow; bill black; feet brown, light brown, or flesh-colour.

Immature. Iris hazel or dark brown (one marked "grey"); bill and feet brown.

The immature bird differs from the adult in having the top and sides of the head olive-green; the mantle and back greenish-olive, more heavily streaked, and the underparts paler yellow, washed with buff, especially on the flanks.

This species was not previously represented in the British Museum, though there were two examples in Mr. Jackson's collection.

Dr. Reichenow describes the female of H. stuhtmanni as having the belly white, washed with brownish, and the under tail-coverts pale golden. Captain Shelley, on the other hand, says that the female is nearly like the male in plumage, with the entire underparts bright yellow. This is no doubt the case, as all our female specimens differ from the males only in having the olive-green of the nape extending on to the occiput, whereas in the males the entire top of the head and nape are black. The 
bird described by Dr. Reichenow as the female of his Il. stuhmanni is certainly neither the adult female nor the young bird of that species; possibly it is the female of $H$. emini Hartl., which more or less answers the description as regards the colour of the belly, \&c.

I may here mention that both Dr. Reichenow and Captain Shelley have united Heterhyphantes zaphiroi (Grant) from Abyssinia with $I$. emini, the latter stating that II. zaphiroi with its black back is merely the summer plumage of $H$. emini. There is no evidence to prove that the feathers of the back in $I$. emini become uniform black in summer, or vice versa, quite the contrary. In the nearly allied H. reichenowi Fischer, which has the abdomen yellow, the feathers of the back remain black throughout the year. All the evidence goes to prove that $H$. zaphirui is a perfectly distinct species. The British Museum possesses an adult male from Adis Ababa procured by Captain Welby. This specimen, like the female type and a second specimen sent by Mr. Zaphiro, has the mantle and back entirely black. The date of capture is not recorded.

[Stuhlmann's Weaver was seen near Entebbe and at Fort Portal; it was numerous on Ruwenzori up to an elevation of $7000 \mathrm{ft}$., both on the eastern and western sides.R. B. W.]

HETERHYPIINTES STEPHANOPHOUUS Sharpe.

Heterhyphantes stephanophorus Sharpe, Ibis, 1891, pp. 11\%, 253, pl. vi. fig. 2; Shellcy, B. Afr. iv. p. 379 (1905).

Ploceus stephanophorus Reich. Vög. Afr. iii. p. 43 (1904).

$a-d$. क et $q$ imm. Mpanga Forest, Fort Portal, 5000 ft., 13th-23̂rd Sept. [Nos. 509, 539, 556.R.E. D.; 3599. R. R.W.

Adult female. Iris crimson or chestnut; bill black; feet slate or grey.

'The female of this species is readily distinguished from that of the nearly allied western representative II. melanogaster (Shelley). In the present species the yellow on the crown scarcely extends beyond the posterior margin of the eye, whereas in the latter species the entire crown is yellow.

In the males of this species the extent of the yellow on the crown seems to vary somewhat. In the type-specimen from Mau, as well as in birds from Nandi and Mount Elgon, the yellow extends considerably behind the eye; while in birds from 'Toro it is shorter and does not usually extend beyond the posterior margin.

[A few examples of Jackson's Yellow-headed Black Weaver were found in the Mpanga Forest, but they were rather uncommon. They appeured to frequent the undergrowth and not the tree-tops. $-R . B . W$. 
IIETERHYPHANTES NigRICOLLIS (Vieill.).

Ploceus nigricollis Reich. Vög. Afr. iii. p. 4t (1904).

Heterhyphantes nigricollis Shelley, B. Afr. iv. p. 381 (1905).

«-e. o ㅇ. Fort Beni, Semliki Valley, $3000 \mathrm{ft}$., ¿23rd \& 24 th July. [Nos. 491. R. E. D. ; 1745. D.C. ; 2429,2432, G. L. ; 3513.R. B.W.]

f. o . Fort Beni, Semliki Valley, $3000 \mathrm{ft.}$. 9th Aug. [No. 3536, R. B.W.]

g. Imm. Mpanga Forest, Fort Portal, $5000 \mathrm{ft}$., 20th Sept. [No. 549. R. E. D.]

Alult male. Iris brown or dark brown; bill black; feet grey or bluish-brown.

Adult female. Iris light or dark brown; bill black; feet grey or slate-colour.

Immature. Bill dusky (pale horn-colour in skin).

In the oldest male examples the back is deep black like the broad nuchal band with which it is confluent, and the fenthers of the rump and upper tail-coverts are mixed with black and olive. In younger male examples the back is strongly washed with olive and contrasts more or less sharply with the black nuchal band; the rump and upper tail-coverts are olive.

[Vicillot's Black-and-Yellow Weaver was not uncommon in the forest near Fort Beni and was also met with in the Mpanga Forest. It has a very remarkable double note, both soft and musical, like the striking of two or three glass finger-bowls at the same time.-R. B.W.]

\section{Cinnamoptery x MPange Grant.}

Cinnamopteryx mpanga Grant, Bull. B. O. C. xxi. p. 15 (190\%).

a. o. Mpanga Forest, Fort Portal, 5000 ft., 20th Sept. [No. 3591. R. B. W. Type of the species.]

This species is most nearly allied to C. tricolor (Hartl.), but the black on the head is continued on to the nape and the yellow band across the upper mantle is much narrower, being confined to three or four series of the shorter feathers, which are merely tipped with yellow and have the blackish basal portion separated by a white band. Iris dark brown; bill black; feet dark brown. 'lotal length ca. 6 inches; culmen 0.5 ; wing 3.5 ; tail 2.05 ; tarsus 0.9 .

Since I described this Weaver I have recently examined three males of this species procured by Mr. Jackson's collectors in the Kibera Forest, 'Toro. 'Two agree in all respects with the type, but in the third specimen the yellow band across the mantle is rather wider, and in this respect approaches the West-African C. tricolor.

[A single example of this Chestnut Weaver was obtained in the Mpanga Forest, east of Ruwenzori. It was one of a pair which bad a nest suspended at the end of a thin bough, about $50 \mathrm{ft}$. from the ground. The nest was about three parts finished by the middle of September, when we moved our camp. Unfortunately we failed to obtain the female. - R. B. W.] 
Hrphantokis pimiditus Antill. \& Salvad.

Ploceus dimidiatus Reich. Vög. Afr. iii. p. 69 (1904).

Hyphantornis dimidiatus Shelley, B. Afr. iv. p. 436 (1905).

a. o . 40 miles W. of Entebbe, $3500 \mathrm{ft} ., 27 \mathrm{th}$ Nov. [No. 2009. G. L.]

b. Imm. 100 miles W. of Entebbe, $4000 \mathrm{ft}$., 7th Dec. [No. 2023. G. L.]

$c, d$. o 120 miles W. of Entebbe, $4000 \mathrm{ft}$., Sth \& 9 th Dec. [Nos. 3044, 3048.

Ii. B. II.]

$e-g$. ㅇ et o imm. Mubuku Valley, S.E. Ruwenzori, $5000 \mathrm{ft.,} 23$ rd-26th March. [Nos. 1409, 1410, 1418. D.C.]

$h-k . \delta$ 오. Mubuku Valley, E. Ruwenzori, $5000 \mathrm{ft}$, 5th April. [Nos. 2272, 2273 , 2275. G. L.]

l-p. of. Mokia, S.E. Ruwenzori, $3100 \mathrm{ft} ., 4$ th-25th May. [Nos. 304, 370, 371. R. F. D. ; 1.29. D. C. ; $3231 \%$. R. R. H.

q. +. Mokia, S.E. Ruwenzori, $3400 \mathrm{ft.,} 17$ th June. [No. 2407. G. L.]

r. ơ . Fort Beni, Semliki Valley, 3000 ft., 22nd July. [No. 1742. D. C.]

Adult male and female. Iris brown or dark brown; bill black in male, lower mandible brown in female; feet brown.

This TVeaver was found breeding at Mokia on the 9 th aud the 25th of May. There are full-plumaged males killed in November, December, April, May, and July. One male specimen dated the 8 th of December is in nearly full plumage, but still retains some of the heavily black-striped feathers of the female plumage on the back, while the underparts are mixed with buff feathers. Another male specimen killed on the 5 th of April, as well as a specimen marked female (No. 3321) obtained on the 4th of May (in full male plumage, vide suprù), have black shaft-stripes to the feathers of the mantle.

'This species ranges from Wadelai in the north to South Ruwenzori in the south, and extends eastwards to Entebbe. It is quite distinct from $H$. jacksoni Shelley, which ranges from Arusha and Kilimanjaro to Lake Baringo and Entebbe. Captain Shelley states that there are in the Jackson Collection specimens of $H$. jacksoni procured at Butiaba, on Albert Nyanza; but this is certainly an error, as one of the specimens in question, a full-plumaged male, is clearly referable to $H$. dimidiatus. I have examined full-plumaged males of both species from Entebbe, where their ranges meet.

The adult male of $I I$. jacksoni may be recognized by having the culmen nearly straight, the black of the head continued on to the hind-neck, the mantle, like the back of the neck, bright yellow, and the breast and belly deep chestuut.

In $H$. dimidiatus the culmen is curver; the black of the head does not extend

* Marked " $ᄋ$," but with plumage like that of the adult male, except that the black on the occiput is mottled with redaish-orange and the back is striped. 
beyond the occiput and is divided from the olive-yellow mantle by a bright yellow collar; the breast is orange-chestnut; and the belly is mostly ycllow, only the sides and flanks being washed with orange-chestnut.

The female of II. jacksoni is ensily distinguished from the female of $I I$. dimidiatus, as the following comparative table of characters will show:-

\section{II. dimidiatus, ㅇ.}

Gencral colour of the back and rump pale brown, the mantle streaked with black; upper tail-coverts sandy-brown.

Throat white; breast and sides of the body pale buff: middle of the belly and under tail-coverts whitish.
II. jacksoni, .

General colour of the back and rump olive, the mantle streaked with black; upper tailcoverts bright olive-green.

Throat and rest of the underparts pale yellow, slightly washed with buff on the sides of the body and flanks.

[Antinori's Black-headed Weaver was plentiful all round the south end of Ruwenzori below $5000 \mathrm{ft}$. and at Fort Beni. It was generally seen singly or in pairs. $-R, B . W$.

'The eggs of $I I$. jacksoni are figured from specimens in the Jackson Collection (Pl. XIX. figs. 2, 4 (eggs)).

\section{Hypiantoris interiedius (Rüpp.).}

Ploceus intermedius Reich. Vög. Afr. iii. p. 72 (1904).

Hyphantornis intermedius Grant \& Reid, Ibis, 1901, p. 622 (S. Abyssinia); Shelley, B. Afr. ir. p. 401 (1905) [part.].

a. +. Nokia, S.E. Ruwenzori, $3400 \mathrm{ft}, 25$ th A pril. [No. 3273. R. B.W.]

$b-f$. o +. " $\quad$, 10th-30th May. [Nos. 396.R. E. D.; 586, 1602. D. C. ; 2361, 2387. G. L.

g. q imm. Mokia, S.E. Ruwenzori, $3400 \mathrm{ft} ., 18$ th June. [No. 470. R. E. D.]

Adult male. Iris white or cream-colour; bill black; feet grey or blue.

Adult female. Iris pale yellow or yellow; bill dark horn-colour or brown; feet grey or slate-colour.

Immature. Iris dark brown; otherwise as in the female.

The luwenzori birds appear to be fairly typical examples of $I 1$. intermedius, but the type from Abyssinia has the nape and occiput rather more strongly washed with brownish-orange. 'The nearly allied $I I$. cabanisi Peters, the southern representative of the present species, has the occiput and nape bright yellow and appears to be a perfectly distinct form. Captain Shelley, who does not keep the two forms separate, has followed the 'Catalogue of Birds' in referring certain specimens in the British Iluseum from Lamu and Pangani to the southern form, H. cabanisi, which he says is found south of the Equator; but, in my opinion, they should really be referred to 
the northern form, H. intermedius. The only ault male procured by Mr. Pease at Daira Aila, in Southern Abyssinia, is clearly referable to H. intermedius.

I have examined full-plumaged males of typical $I I$. intermedius from Shoa, Southern Abyssinia, Lamu, Pangani, and from South-east Ruwenzori ; and of 11 . cabanisi from Nyasaland, Matabele, Bamangwato, and Damaraland.

[The Intermediate Masked Veaver was only met with on the plains at the southeast end of Ruwenzori. - R. B. W.]

\section{Hyphantornis FeMinina Grant.}

Hyphantornis feminina Grant, Bull. B. O. C. xxi. p. 15 (1907).

a. o. 30 miles W. of Entebbe, 3500 ft., 26th Nov. [No. 2006. G. L.]

b. ․ 40 miles W. of Entebbe, $3500 \mathrm{ft} ., 27$ th Nov. [No. 3010. R. B. W.]

c. đ. 50 miles W. of Lntebbe, $3700 \mathrm{ft.}, 28$ th Nov. [No. 2010. G. L.]

d-n. ơ q. Mokia, S.E. Ruwenzori, 3400 ft., 2Sth-30th April. [Nos. 256, 258. d. d. d.

R. E. D. ; 1464. D. C. ; 2296, 2301, 2302, 2308. G. L. ; 3294, 3296, 3297. R. B.W.]

o-x. o q. Mokia, S.E. Ruwenzori, 3400 ft., 2nd-24th May. [Nos. 321, 322 *, 323, 327, 363. R. E. D.: 2317 *, 2390. G. L. ; $3355,3356,3370 . R . B . W$.

$y, z$.. Mokia, S.E. Ruwenzori, $3400 \mathrm{ft}$. , 4th \& 6ith June. [Nos. 423, 434. R.E.D.]

'The alult male does not appene to differ in any marked particular from typical males of H. abyssinious (Gmel.). Iris pink, red, orange, chestnut, or brown; bill dark horn-colour or black; feet brown or flesh-colour. 'Total length 5.8 inches; culmen 0.85 ; wing 3.5 ; tail 2.05 ; tarsus 0.9 .

The adult female differs from the female of $H$. abyssinicus (Gmel.), which has the chin and throat yellow and the rest of the underparts buff, in having the underparts

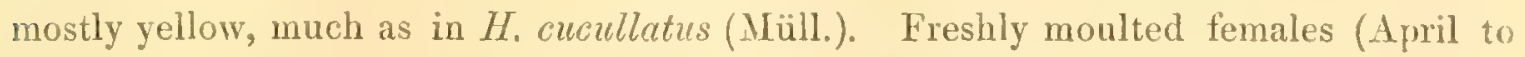
May) have the mantle and back washed with dull greenish-yellow, while in a winter specimen (November) these parts are greyish-brown in strong contrast to the head and nape, which are washed with yellow. Total length $5 \cdot 8$ inches; culmen 0.85 ; wing $3 \cdot 15$; tail 1.95 ; tarsus 087.

There are numerous examples of this form in the Jackson Collection from various localities in Uganda.

[This large Weaver was plentiful on the plains at the south-eastern end of Ruwenzori and also at Fort Beni. It was breeding in large colonies in the acacias and hundreds of nests might be seen in a single tree. $-R . B . W$.]

\footnotetext{
* Types of the species.
} 
Hyphantornis xaNTHops Hartl.

Ploceus xanthops Reich. Vög. Afr. iii. p. 88 (1901).

P.x.jamesoni (Sharpe) and P.x. camburni (Sharpe); Reich. 1. c. p. 90 (1904).

Xanthophihes xanthoys Shelley, B. Afr. iv. 1. 483 (1905); Jackson, Ibis, 1906, p. 566 [Toro].

Hyphantornis xanthops Grant, Ibis, 1908, p. 277 [Lakes Kivu and Tanganyika].

$a-\ell$. ㅇ et $\delta^{*}$ o $\mathrm{imm}$. Mubuku Valley, E. Ruwenzori, $5000 \mathrm{ft}$., 14th-28th March. [Nos. 216.R.E. D.; 2229, 2254.G.L.; 3219.R.B.W.]

e, f. o imm. Mubuku Valley, E. Ruwenzori, $5000 \mathrm{ft} ., 4$ th \& 5 th April. [Nos. 2269, 2274. G. L.]

g. o. Mokia, S.E. Ruwenzori, $3400 \mathrm{ft.}$ 18th May. [No. 2362. G. L.]

h, i. o imm. Mokia, S.E. Ruwenzori, 3100 ft., 5th \& 6th June. [Nos. 428. R. E. D. ; 3459.R. B.W.]

Adult male. Iris yellow; bill black; feet brown.

Adult female. Iris cream-colour; bill black; feet flesh-colour or brown.

Immature. Iris grey or dark brown; bill yellow (dark at the base); feet brown or slate-colour.

D1: Reichenow regards $I$. camburni Sharpe and H. jamesoni Sharpe as subspecies of $H$. xanthops. There can, however, be no doubt that the type of $H$. camburni, from the Nairobi Forest, is a quite young male example of $H$. xanthops; while the type of $I$. jamesoni, from the Umvuli River, is a nearly adult male of the same species, but with less yellow on the bead. Captain Shelley has very properly united all under II. xanthops, but at the same time he maintains that the southern form from south of the Zambesi (H. jamesoni) is a greener bird, while that found to the north is brighter and yellower (H.aurantirgula Cab. and H.camburni). The series in the British Museum seems, however, to show that birds from the south when fully adult are almost, if not quite, as bright as examples from the more northern parts of this bird's range. Of two male birds collected by Mr. Carruthers at Lakes Kivu and Tanganyika respectively, that from the former and more northern locality has the back greener and the crown much less brilliant, the difference being no doubt entirely due to age.

[A few examples of Hartlaub's Golden Weaver were seen on the plains on the east. side of Ruvenzori. $-R, B . W \cdot]$

\section{Hrphantornis castanors (Shelley).}

Ploceus castanops Reich. Vög. Afr. iii. p. 96 (1904).

Tanthophilus castanops Shelley, B. Afr. iv. p. 471 (1905).

a, b. o ㅇ. Fort Portal, $3500 \mathrm{ft}$., 5th July. [Nos. 3499, 3500. R. B.W.]

Iris very pale yellow; bill black; feet brown.

The male, a very fine specimen, has the lores and chin black, and, in this respect, differs slightly from any of the specimens in the British Museum or in the Jackson Collection. 
[A few examples of the Nile Brown-throated Weaver were seen at Fort Portal. They were breeding in July; their nests, rather small in size and almost perfectly round, were composed of fine strips of grass and creepers not very compactly woven together. There were five or six nests hanging from the boughs of a small tree, but only one pair of birds appeared to inhabit the tree.- $R . B .[V$.

\section{HYPHAXTORXIS SUPERCiLIOSUS (Shelley).}

Ploceus superciliosus Reich. Vüg. Afr. iii. p. 96 (190 h).

Pachyphantes superciliosus Shelley, B. Afr. iv. p. 448 (1905).

a-e. o ㅇ. Fort Beni, Semliki Valley, 3000 ft, 22 nd July. [Nos.490. R. E. D.; 1741. D.C.; 2422, 2423, 2424. G. L.]

Iris brown or dark brown; upper mandible black, lower mandible grey ; feet brown.

When volume xiii. of the 'Catalogue of the Birds' was written the series of examples of this species in the British Museum included only West-African specimens, which rangerl from the Gold Coast to the Loango Coast and northwards to Shonga on the River Niger. The species is known, however, to occur in Liberid and to extend eastwards to the Lakes. There are four examples in the Jackson Collection from Lewekala, in Uganda, killed in the month of August, and these, like the July specimens in the present collection, are in full or nearly full breeding-plumage.

['The Compact Weaver was only met with in the neighbourhood of Fort Beni, where it was not uncommon.-R. B. W.]

Sitagra aliena Sharpe. (Plate XIX. fig. 18, egg.)

Sitagra aliena Sharpe, Bull. B. O.C. xiii. p. 21 (1902); Jackson, Ibis, 1906, p. 565 [Ruwenzori].

Ploceus alienus Reich. Vög. Afr. iii. p. 68 (1901).

Hyphanturgus alienus Shelley, B. Afr. iv. p. 392, pl. xxxix. fig. 2 (1905).

$a-h$. of $q$ et of imm. Mubuku Valley, E. Ruwenzori, 6000-7000 ft., 5th-20th Jan. [Nos. 65, 68, 81, 86, 117.R. E. D.; 1103, 1116, 1139. D.C.]

$i, k$. o $q$. Mubuku Valley, E. Ruwenzori, 6500-7000 ft., 6th \& 11th Feb. [Nos. 2145, 2154.G.L.]

l-s. o + et o o imm. Mubuku Valley, E. Ruwenzori, 7000-9000 ft.o, Sth-26th March. [Nos. 194. R. E. D.; 1369, 1370. D. C.; 2215, 2244, 2245, 2249. G. L.; 3235. R. B. W.]

Iris red or dark red; bill black; feet brown, blue-grey, or slate-colour.

A fine series of this handsome Weaver was collected in all stages of plumage from the quite young bird to the fully adult. Descriptions of some of these plumages will 
be found in Captain Shelley's work, but they require modification, being partly based on assumption.

Seven adult males have the entire head and throat black, the latter bordered by a wide chestnut area.

Six adult females have the chin and upper part of the throat black and the lower part of the throat deep chestnut, like the surrounding area.

Two skins marked $\sigma^{*}$, one in the Jackson Collection and the other (No. 117) procured by Mr. Dent, have the throat like that of the adult females described above, the black feathers not extending beyond the upper part of the throat. Mr. Dent notes that his specimen was "breeding," and though it is difficult to believe that so careful a collector can have made a mistake, it seems probable that he has accidentally marked " 8 " on the label where he meant to mark "오."

An apparently fully adult female shot by Mr. Legge (no. 2244) has only the chin black, the whole throat being chestnut.

Five specimens (two males and three females) are in partially immature plumage, with the base of the under mandible whitish and with many of the feathers of the head and throat olive, like the back. 'The black feathers on the throat are confined to the upper part in males and females alike.

In a younger female the entire head and throat are olive-colour, the feathers of the upper chest being tinged with orange, indicating the position of the chestnut area.

In a still younger male the middle of the breast and belly is white tinged with buff and mixed with a few yellow feathers on the sides.

'The nest found on the $23 \mathrm{rd}$ of January contained two eggs, of a long oval shape and devoid of gloss. The ground-colour is creamy-white thickly speckled with brickred and with a fer underlying spots of dull lavender-grey. They measure respectively .93 by $\cdot 58$ and $\cdot 88$ by $\cdot 59$.

[The Alien Weaver was found on Ruwenzori from an elevation of $5500 \mathrm{ft}$. up to S.) 00 , frequenting both the forest and the more open country below. A nest found at an altitude of $6000 \mathrm{ft}$. was suspended from the end of a bough, about $10 \mathrm{ft}$. above the ground, and was composed almost entirely of the thin tendrils of creepers with a few fine strips from blades of grass. $-R . B . W$.

\section{Sitagra ocularia (Smith).}

Ploceus ocularius p. 45 and P. o. crocatus (Hartl.) p. 46, Reich. Vög. Afr. iii. (1904).

Hyphanturgus ocularius Shelley, B. Afr. iv. p. 385 (1905).

", b. ㅇ. Mubuku Valley, E. Riuwenzori, $6000 \mathrm{ft}, 29 \mathrm{th} \& 31 \mathrm{st}$ Dec. [Nos. $107 j$. D. C. ; $\left.2036 . G . L_{0}\right]$

c, d. ot et $9 \mathrm{imm}$. Mubuliu Valley, E. Ruwenzori, 5000-6000 ft., 3rd \& 7 th April. [Nos. 2266, 2280. G. L.] 
e-i. of $q$ et $\delta^{*}$ i imm. Mokia, S.E. Rumenzori, $3400 \mathrm{ft.}$, 5th-29th May. [Nos. 301, 385, 391. R. E. D. ; 1613. D. C.: 3324.R.B.W.]

k. o . Fort Beni, Semliki Valley, 3000 ft., 24th July. [No. 496. R. E. D.]

Adult male. Iris varies from pale yellow to dark brown; bill black; feet pink, grey, or slate-colour.

Adult female. Tris white or cream-colour; bill black; feet slate- or blue-grey.

According to Dr. Reichenow the bird from Equatorial and East Africa, as far south as Nyasaland, \&c., belongs to a rather smaller and more richly coloured race, which has been named $S$. crocata (Hartlaub). I have compared typical examples of this form from Equatorial Africa with the type of S. ocularia (Smith) and with a series of specimens from Natal and other parts of South Africa, and am unable to see any difference in plumage, though the bill of the southern form is, on the whole, slightly longer, but the difference is trifling. The male $(k)$ from Fort Beni killed on the 24th of July is marked "breeding" by Mr. Dent.

[This Spectacled Weaver was seen occasionally on the plains around Ruwenzori, both on the east and west sides, but it was not very numerous. It frequented chiefly the dense and tangled vegetation along the streams. $-R . R . W$.

Sitagra Pelzelin (Hartl.).

Icteropsis pelzelni Jackson, Ibis, 1899, p. 610 (Entebbe); Hartert, Nov. Zool. vii. p. 40 (1900)

(Lake Edward); Jackson, Ibis, 1906, p. 566 (Toro).

Ploceus pelzelni Reich. Vög, Afr, iii. p. 75 (1901).

Situgra pelzelni Shelley, B. Afr. iv. p. 39t (1905).

a-c. ot. Mokia, S.E. Ruwenzori, 17th-28th June. [Nos. 1641, 1684, 1705. D.C.]

Adult male. Iris dark hazel or pale yellow ; bill black; feet dark mauve, dark grey, or brown.

These birds are in worn plumage and rather dull in colour, especially on the underparts.

[Pelzeln's Slender-billed Weaver was only seen near the sonth end of Ruwenzori, where it was very rare.- $R . B . W$.

\section{Sitagra luteola (Licht.).}

Ploceus luteolus Reich. Vögr. Afr. iii. p. 76 (1901).

Sitagra luteola Shelley, B. Afr. iv. p. 397 (1905); Jackson, Ibis, 1906, p. 565 [Toro].

$\alpha$, b. o +100 miles W. of Entebbe, $4000 \mathrm{ft} ., 6$ th Dec. [Nos. 3030, 3031. R. B. II.]

c. o imm. Mokia, S.E. Ruwenzori, $3400 \mathrm{ft} .9$ th May. [No. 3340. R. B. W.]

The adult male in the present collection differs somewhat from all the adult male vol. XIX.-PART IV. No. 38.-March, 1910. 
specimens of $S$. luteola in the British Museum in having the black extending somewhat further back over the cromn, about $3 \mathrm{~mm}$. behind the posterior margin of the eye while the mantle and back have rather distinct dusky streaks. Specimens in the Jackson Collection from 'Toro agree with the Entebbe bird in the latter respect, but as regards the extent of black on the head they resemble typical S. luteola. It must be noted that all the specimens in the British Museum bearing dates were killed during the summer months between May and July, while both the birds from Entebbe in the present collection and those in the Jackson Collection from Toro were obtained in winter, in December and March respectively, so that the striped back may be, and probably is, characteristic of the winter plumage.

[Lichtenstein's Slender-billed Weaver was seen, very occasionally, on the eastern side of Ruwenzori below an altitude of $5500 \mathrm{ft}$., also at Entebbe.-R. B. W.]

Amblyospiza melanonota (Heugl.). (Plate XIX. figs. 15 \& 16, eggs.)

Amblyospiza melanotus Reich. Vög. Afr. iii. p. 100 (1904); Shelley, B. Afr. iv. p. 307 (1905). Amblyospiza melanonota Jackson, Ibis, 1906, p. 567 [Toro].

a. ?. Mokia, S.E. Ruwenzori, $3400 \mathrm{ft}, 28$ th April. [No. 328S. R. B.W.]

b-d. \& ‥, $\quad " \quad$ 3rd \& 22nd May. [Nos. 1486. U. C.; ไ382, 2383. G. L.]

e,f. ㅇ. Mokia, S.E. Ruwenzori, $3400 \mathrm{ft} .$, 16th June. [Nos. 466, 467. R. E. D.]

g. on imm. Butagu Valley, W. Ruwenzori, $4000 \mathrm{ft.,} 28$ th July. [No. 2439. G. L.]

Adult. Iris dark brown; bill black (in the male); upper mandible olive, lower yellow (in the female); feet dark grey or black.

The male specimens have the head, neck, mantle, and chest very dark chestnut, darker than in the majority of specimens from Uganda and from the White Nile; one of Mr. Jackson's specimens from Entebbe, Uganda, is, however, equally dark in colouring.

The birds procured at South-east Ruwenzori in May were breeding, and one female (No. 2382) is marked as having been shot off the nest.

'Two clutches of eggs were procured on the 17th and 22nd of May. They are of a rather long oval form and slightly glossy. One set of three eggs has the ground-colour pale pinkish-white, spotted, especially towards the larger end, with maroon-red. The second set of two eggs has the ground-colour pale red, marked with darker spots of the same colour. They measure from $\cdot 85$ to $\cdot 95$ in. in length and from $\cdot 58$ to 6 in breadth.

[Only a few examples of Heuglin's Grosbeak-Weaver were met with on the plains at the south-east of Ruwenzori, but on the west between Fort Beni and the foot of the mountains they were quite numerous. When flying they much resembled the Common Hawfinch. 'They frequented the tall reeds along the streams, but only such streams as 
were among or near trees. The nest of this species is, I think, the most compact and beautiful built by any of the Weavers; it is attached to two tall reeds and is composed of very fine strips of grass or reed-leaf. Both birds take part in its construction, and a nest we had under observation took about fourteen days to complete.- $R . B . W$.]

Spermospiza poliogenis Grant. (Plate X. fig. 2, ․)

Spermospiza poliogenys Grant, Bull. B. O.C. xix. p. 32 (1906); id. Ibis, 1908, p. 278 [Kasongo, Upper Congo].

a. ㅇ. 20 miles N. of Fort Beni, Semliki Valley, $3000 \mathrm{ft}$, 11th Aug. [No. 1775. D.C. Type of the species.]

The female is similar to the adult female of $S$. guttata (Vieill.), but the cheeks and sides of the face are dark grey like the crown; some of the feathers on each side of the breast are tipped with scarlet and form an indistinct patch.

Iris dark brown; bill red and black; feet dark brown. Total length 5.3 inches; wing 2.8 ; tail 2.0 ; tarsus 0.88 .

A single adult female specimen was procured by Mr. Douglas Carruthers in the thick forest. A second less mature female example of the same species was procured by the same collector on the Upper Congo on the 7 th February, during his return journey to the West Coast.

[A single specimen of the Grey-cheeked Weaver-Finch was obtained in the Eturi Forest between Fort Beni and Irumu.-R. B.W.]

Prrenestes ostrinus (Vieill.).

Pyrenestes ostrinus Reich. Vög. Afr. iii. p. 106 (1904) [part.]; Shelley, B. Afr. iv. p. 284 (1905).

a. o. Mawambi, E. Congo Forest, $3000 \mathrm{ft} ., 27$ th Oct. [No. 3643. R. B.W.]

Iris chocolate-colour; bill dark bluish-grey; feet light brown.

The size of the bill appears to vary greatly in the males of this species. In the present specimen it is moderately developed, while in two examples in the British Museum, from Gaboon und Tingasi respectively, it is very large and strong.

[Vieillot's Notch-billed Weaver was occasionally seen in the E. Congo Forest.R. B.W.]

Quelea quilea (Linn.).

Quelea quelea Sharpe, Cat. Birds B. M. xiii. p. 257, pl. x. fig. 3 (1890); Shelley, B. Afr. iv. p. 111 (1905).

Quelea intermedia (Reich.); Sharpe, Cat. Birds B. M. xiii. p. 259, pl. x. fig. 4 (1890).

Quelea sanguinirostris Reich. Vög. Afr. iii. p. 108 (1901).

Quelea sanguinirostris lathami Reich. t. c. p. 110 (1904). 
a-d. o . Mubuku Valley, E. Ruwenzori, $5000 \mathrm{ft}, 19 \mathrm{th}-22 \mathrm{nd}$ March. [Nos. 21T. R.E.D.; 1384.D.C.; 2219, 2231.G.L.]

$e-g$. of ㅇ․ Mokia, S.E. Ruwenzori, $3400 \mathrm{ft} ., 4$ th-19th June. [Nos. 427. R. E. I. ; 1627, 1650. D.C.]

h, i. o . Fort Beni, Semliki Valley, 3000 ft., 22nd \& 24th July. [Nos. 489, 495. R.E. D.]

Adult male and femule. Iris varies from hazel to dark brown; eyelids red; bill coral-red ; feet vary from rose or pink to yellowish-brown or brown.

Adult males $(a-d)$ of the Black-fronted Dioch, all killed in March and some of them marked "breeding," vary greatly in colour; in some the crown and chest are rosy, while in others these parts are sandy buff. Again, in some specimens there is a stronglymarked black band across the forehead, while in others it is narrow and ill-defined.

Quelea CARDinalis (Hartl.).

Quelea cardinatis Reich. Vög. Afr. iii. p. 112 (1904); Shelley, B. Afr. iv. p. 119 (1905); Grant, Ibis, 1908, p. 270 [Lake Tanganyika].

a. [o imm.] 60 miles W. of Entebbe, $3700 \mathrm{ft}$., 29th Nov. [No. 3017. R. B.W.] Iris dark brown; bill and feet brown.

[The Cardinal Dioch was only procured near Entebbe.- $R . B . W$.

Prromllana axsongei Hartert.

Pyromelana ansorgei Hartert, in Ausorge, Under Afr. Sun, App. p. 31.4, pl. ii. fig. 2 (1899); Reich. Vög. Afr. iii. p. 117 (1904); Shelley, B. Afr. iv. p. 102 (1905); Neumaun, Bull. B. O. C. xxiii. p. 47 (1908).

Pyromelane xanthochlamys Sharpe, Bull. B. O. C. xiii. p. 10 (1903).

Penthetria hartlaubi Cab. and Coliuspasser dubiosus Neumann, Bull. B. O. C. xxiii. p. 47 (1908).

a-c. of o imm. Mubuku Valley, E. Ruwenzori, 5000 ft., 14th-19th March. [Nos. 1381, 1382. D. C.; 2194.G. L.]

d. o . Fort Beni, Semliki Valley, $3000 \mathrm{ft}$, 22nd July. [No. 488. R. E. D.]

Adult male. Iris dark brown; bill and feet black.

Immature male and female. Iris dark brown; upper mandible black, lower brown, whitish towards the base; feet dark brown.

I have compared the adult male in the present collection with the type-specimen of $P$. ansorgei Hartert from Masindi, Unyoro, and also with the type of $P$. xanthochlamys Sharpe from Hoima, Unyoro (not Ruwenzori, as stated by Captain Shelley). There can be no doubt that all three specimens belong to the same species. Mr. Alexander also procured a specimen at Gudima, on the Kibali River. All the four specimens mentioned above are males in full breeding-plumage; the adult fermale is still unknown. 
Prof. Neumann has shown that Penthetria hartlaubi Cab. and Coliuspasser dubiosus Neumann are males of this species in winter-plumage.

Three immature birds $(a-c)$ procured in the Mubuku Valley are almost certainly referable to the present species; they have black under wing-coverts as in the adult male and generally resemble that bird, especially as regards the size and shape of the bill.

'The immature female may be described as follows :-

Top of the head and upperparts black, each feather margined on the sides with sandy-buff, the margins being narrowest on the feathers of the forehead ; superciliary stripe and sides of the neck mostly buff; cheeks mottled black and buff; underparts buff, whitish on the middle of the belly, the chest and sides of the breast being darkest, ench feather with a small subterminal triangular black spot at the extremity; upper wing-coverts, quills, and tail-feathers black, margined with sandy-buff; under wing-coverts black: wing $2 \cdot 8$ inches; tail 2.0 .

The immature male resembles the above, but is somewhat larger and the chest is marked with brighter yellowish-buff: wing $3 \cdot 0$ inches; tail $2 \cdot 15$.

[A few examples of Ansorge's Bishop-bird were seen near Fort Beni in the Semliki Valley. The male procured was breeding. $-R . B . W$.]

Pyromelana flammiceps (Swains.).

Pyromelana flammiceps Reich. Vög. Afr. iii. p. 118 (1904); Shelley, B. Afr. iv. p. 104 (1905); Jacksou, Ibis, 1906, p. 561 [Toro]; Grant, Ibis, 1908, p. 269 [Lake T'anganyika and Kasongo].

a. o. Lower Semliki Valley, $2500 \mathrm{ft.}$, 11th Oct. [No. 564. R. E. D.]

Iris dark brown; bill black; feet flesh-colour.

This specimen of the Fire-crowned Bishop-bird is in worn breeding-dress, and has a few feathers of the winter-plumage beginning to make their appearance on the throat. It is an interesting specimen, having a distinct black band $3 \mathrm{~mm}$. in width above the base of the culmen.

There is a perfectly similar specimen in the British Museum procured by Sir $\mathbf{H}$. H. Johnston at Nandi; and out of four specimens sent by Emin from Tingasi, two have a well-marked narrow black band across the forehead, one has a narrow line of black feathers, while the fourth has the forehead orange-scarlet to the base of the culmen.

I have examined a large series of males in breeding-plumage and make the following notes :-

13 adult males from Sierra Leone. Mostly with a single row of black feathers at the base of the culmen; the remaining specimens have the forehead orauge-scarlet to the base of the culmen.

8 " " Gold Coast. As above. 


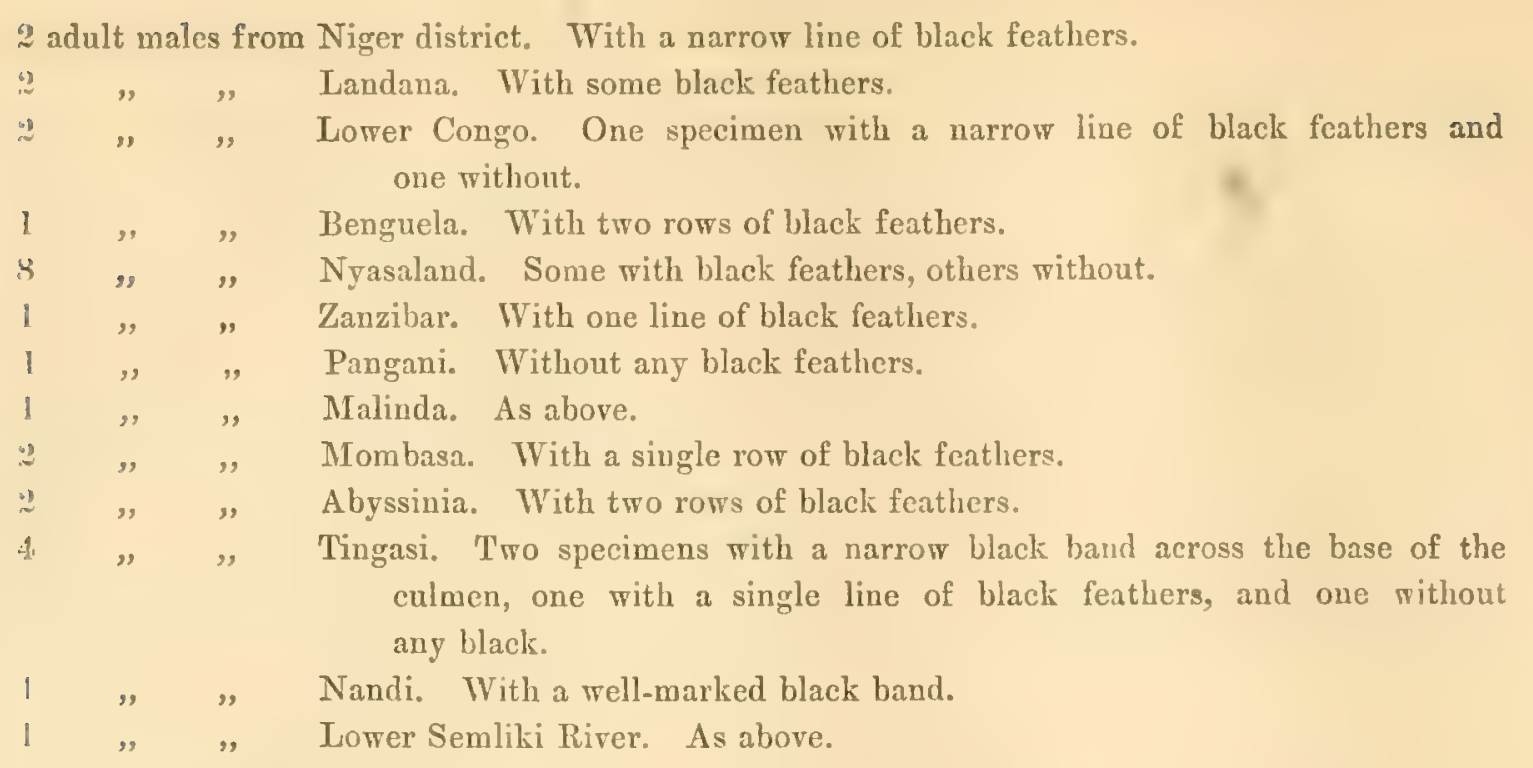

It is thus evident that the black band across the forehead, when present, is most developed in birds from Equatorial Africa, but since specimens both with and without a black band occur in the same locality, it is obviously a character of little importance.

\section{l'yronelana nigRIFrons Böhm.}

Pyromelana nigrifrons Hartert, Nov. Zool. vii. p. 4.1 (1900) [Toro; Fort George, Lake Edward]; Reich. Vög. Afr. iii. p. 122 (1904).

Pyromelana sundevalli Shelley (nec Bonap.), B. Afr. iv. p. 98 (1905); Grant, Ibis, 1908, p. 268 [Lake Tanganyika and Kasongo].

a. ơ imm. 120 miles TV. of Entebbe, $4000 \mathrm{ft}$., 8th Dec. [No. 39. R. E. D.]

b. ㅇ imm. Mubuku Valley, E. Ruwenzori, $5000 \mathrm{ft}$, 19 th March. [No. 1338. D. C.]

c-e. o . Mokia, S.E. Ruwenzori, $3400 \mathrm{ft} ., 25 \mathrm{th}-28 \mathrm{th}$ A pril. [Nos. 1431, 1432. D. C.; 2299. G. L.]

$f^{\prime} k$. o . Mokia, S.E. Ruwenzori, $3400 \mathrm{ft} ., 1$ st-15th May. [Nos. 1472, 1473, 1474, d.

1564. D. C.;2339. G. L.]

Adult male. Iris dark hazel or dark brown; bill black; feet brown or light brown. Adult female. Iris dark brown; bill and feet brown.

In male specimens in breeding plumage the amount of black on the chin varies greatly; in some specimens there is only a trace of it, while in others the whole chin is conspicuously black. In examples procured from S.E. Ruwenzori the mantle varies from uniform cinnamon slightly washed with red to cinnamon washed with scarlet and laterally strcaked with black.

It would appear that the specimens procured by Doggett and referred by me to P. wertheri Reichenow ( $f f$. 'Ibis,' 1905, p. 207) are merely paler-backed forms of 
P. nigrifions. The true $P$. wertheri from the Wembere Steppes is said to have the black on the forehead extending backwards to the crown, as in the South African $P$. ory $x$, whereas both the specimens of $P$. nigrifrons from Ruwenzori and the birds referred by me to $P$. wertheri have the black on the forehead less developed and not extending beyond the eye.

['The Red Bishop-bird was not uncommon among the reeds along the streams intersecting the plains at the south end of Ruwenzori. $-R . B . W$.

Pyromelana franciscana (Isert).

Pyromelana franciscana Sharpe, Ibis, 1902, p. 119; Reich. Vög. Afr. iii. p. 122 (1904) : Shelley, B. Afr. iv. p. 90 (1905).

Pyromelana franciscana pusilla Hartert, Bull. 13. O. C. xi. p. 71 (1901).

a. 3. Lower Semliki Valley, $2000 \mathrm{ft}$, 10th Oct. [No. 561. R. E. D.]

Iris dark brown; bill black; feet flesh-colour.

A fine adult male of the Red-throated Bishop-bird in the present collection has a wing measuring $61 \mathrm{~mm}$. Dr. Hartert has separated the form found at Lake Stephanie under the name $P . f$. pusilla, on account of its supposed smaller size (wing 60 to $63 \mathrm{~mm}$.), but I agree with Dr. Sharpe and others in regarding it as synonymous with P. franciscana.

[A few were seen on the Semliki River near the north end of Ruwenzori. 'The male procured was breeding. $-R . B . W$.

Pyromelana xanthomelas (Rüpp.).

Euplectes xanthomelas Reich. Vög. Afr. iii. p. 128 (1904).

Pyromelana xanthomelas Shelley, B. Afr. iv. p. 76 (1905); Grant, Ibis, 1908, p. 268

[Mufumbiro, Lakes Kivu and Tanganyika].

a. o . Luimi Valley, E. Ruwenzori, $6000 \mathrm{ft}$., 1st Oct. [No. 3620. R. B.W.]

b. ơ . Mubuku Valley, E. Ruwenzori, $5000 \mathrm{ft}$, 14th March. [No. 2193. G. L.]

The male example of Rüppell's Black-and-Yellow Bishop-bird killed in October is beginning to assume winter-plumage, while that killed in March is in full winterplumage. Both are rather smaller than Abyssinian specimens and have a wing measuring 2.85 inches (72 $\mathrm{mm}$.).

[A few were seen on the north-east slopes of Ruwenzori, below $6000 \mathrm{ft}$., but the species was very uncommon.- R. B.W.]

Pyromelana crassinostris Grant. (Plate $\mathbf{X}$. fig. 3, [ $\sigma^{*}$ )

Pyromelana crassirostris Grant, Bull. B. O. C. xxi.p. 14 (1907).

a. [o.] North end of Ruwenzori, $3500 \mathrm{ft} ., 19$ th Aug. [No. 2452. G. L. Type of the species.] 
This species is most nearly allied to P. phonicomera G. R. Gray, but is smaller; the bill is shorter, stouter, and deeper, its length being $16 \mathrm{~mm}$, and the depth of the upper mandible at the gape $7 \mathrm{~mm}$. (whereas in $P$. phonicomera it measures only $5 \frac{1}{2} \mathrm{~mm}$.) ; the yellow shoulder-patch is much less extensive and is not continued over the scapulars. Iris dark brown; bill dusky; feet brown. Total length ca. 5.0 inches; wing 2.55 ; tail 1.95 ; tarsus 0.82 .

[The only known example of the Thick-billed Bishop-bird was procured by Mr. Gerald Legge on the northern slopes of Ruwenzori, below $4000 \mathrm{ft} .-R . B . W$.]

Urobrachis PHENICEA (Heugl.).

Urobrachya phoxicea Rcich. Vög. Afr. iii.p. 130 (1901); Shelley, B. Afr.iv. p. 65 (1905); Grant, Ibis, 1908, p. 269 [MIufumbiro].

$\alpha-\ell . \delta$ et o imm. 120 miles W. of Entebbe, $4000 \mathrm{ft} ., 8$ th \& 9 th Dec. [Nos. 3041 , $3042,3043,3049,3050 . R . B . W$.

f. ơ. Mpanga Forest, Fort Portal, $5000 \mathrm{ft} ., 16$ th Sept. [No. 3575. R. B.W.]

g. ㅇ. Mokia, S.E. Ruwenzori, $3400 \mathrm{ft} ., 17$ th May. [No. 1577. U.C.]

h. ․ " " " $\quad$ 15th June. [No. 2402. G. L.]

i. o . Fort Beni, Semliki Valley, $3000 \mathrm{ft}$., 20th July. [No. 483. R. E. D.]

$k, l$. o o . 60 miles N. of Fort Beni, 3500 ft., 16th Aug. [Nos. 17S7, 1788. D. C.]

Adult male. Iris dark brown or dark hazel; bill light grey or bluish-white; feet dark brown or black.

Adult female. Iris dark brown or dark hazel; bill brown or horn-colour; feet brown or light brown.

The adult males shot in July, August, and September are in full breeding-plumage.

Three of the adult birds collected on the Sth and 9th of December have nearly assumed their winter dress, while the fourth is still in the black breeding-plumage.

The two females (Nos. 1577 and 2402) have the lesser wing-coverts conspicuously margined with dark orange, forming a well-marked patch on the shoulder; No. 1788 lias the lesser wing-coverts rather inconspicuously margined with yellowish. All three birds appear to be perfectly adult, and No. 1577 is marked "breeding" by Mr. D. Carruthers. The pale-shouldered specimen (No. 1788) was one of a pair (of which the male, No. 1787, is in perfect breeding-plumage) and is in worn plumage. Possibly the orange shoulder-patch is not assumed till after the second moult.

[Heuglin's Fan-tailed Whydah was seen throughout the journey from Victoria Nyanza to the Congo Forest, but was not met with on Rurenzori above an altitude of $5000 \mathrm{ft} .-R . B . W .1$

\section{Coliuspasser ardens (Bodd.).}

Penthetria ardens Jackson, Ibis, 1899, 1. 598 [Entebbc]; 1906, p. 560 [Toro].

Coliuspasser ardens Reich. Vög. Afr. iii. p. 135 (1904); Shelley, B. Afr. iv. p. 40 (1905). 


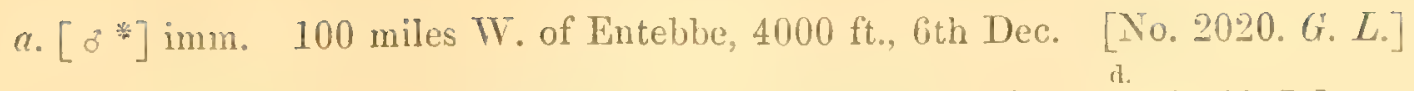

b. Imm. 120 miles W. of Entelbe, $4000 \mathrm{ft}$., 8th Dec. [No. 40. R. E. D.] $c-l$. o f et on imm. Mubuku Valley, E. Ruwenzori, $5000 \mathrm{ft}$., 1st \& 2Sth March. d.

[Nos. 177, 213, 227. R. E. D.; 1406, 1407, 1419, 1420, 1421. D. C.; 2257. G. L.]

m, n. o . Mokia, S.E. Ruwenzori, 3400-4000 ft., 8th May \& 22nd June. [Nos. 1522, a.

1668. D. C.]

Alult male (in breeding-dress). Iris dark brown or clark hazel; bill and feet black. Alult female. Iris dark hazel; bill and feet brown.

Young males and females. Iris brown, dark brown, or dark hazel; bill and feet brown.

[The Red-collared Whydah was not found on Ruwenzori above $5000 \mathrm{ft}$. $-R . B . W$.]

Var. Coliuspasser coxcolor (Cass.).

Coliuspasser concolor Reich. Vög. Afr. iii. p. 134 (1904); Shelley, B. Afr. iv. p. 44 (1905).

a. o. Mubuku Valley, E. Ruwenzori, 5000 ft., 2Sth March. [No. 2256. G. L.]

Tris dark brown; bill black; feet dark brown.

There can be very little doubt that the Black Whydah is merely a melanistic form of $C$. ardens in which the scarlet or orange band across the chest, characteristic of the typical form, is wanting. There are four male specimens of so-called C. concolor in the British Museum and two in the Jackson Collection. Of these, four show no trace of a pectoral band, but in two specimens it is very faintly indicated. 'These intermediate forms are considered by Captain Shelley to be hybrids between $C$. ardens and C. concolor, but the fact that the black form is found in widely scattered localities along with typical specimens of $C$. ardens seems to indicate that it is merely a colourvariety of that bird.

[Cassin's Black Whydah was only met with on the plains below the mountains.R. B. W.]

\section{COliuspasser sonor (Reichenow).}

Coliuspasser soror Reich. Vög. Afr. iii. p. 138 (190-t); Shelley, B. Afr. iv. p. 53, pl. 29. fig. 2 (1905).

a. o. 120 miles W. of Entebbe, $4000 \mathrm{ft}$., 9th Dec. [No. 44. R. E. D.]

Iris dark brown; bill and feet black.

A male of Reichenow's Yellow-shouldered Whydah assuming winter dress. 'The species was not met with on Ruwenzori.

VOL. Xix.-PART IV. No. 39.-March, 1910.

$$
2 k
$$


Coliuspasser eques (Hartl.).

Penthetriu eques Hartert, Nov. Zool. vii. p. 41 (1900) [Holulu R., Seruliki]; Jackson, Ibis, 1906 , p. 561.

Coliuspasser eques Reich. Vög. Afr. iii. p. $1+1$ (1904); Shelley, B. Afr. iv. p. 45 (1905).

a. o . Mokia, S.E. Ruwenzori, $3400 \mathrm{ft} ., 26 \mathrm{th}$ April. [No. 1437. D. C.]

b.c. 우. " $\quad$ " $\quad$ 1st\& 22nd May. [No. 2312, 2384. G. L.]

d. o imm. ", ", $\quad$ 12th June. [No. 1624. D. C.]

Adult male. Iris dark brown or dark hazel; bill blue or blue-grey; feet black.

Adult female. Iris, bill, and feet brown.

The specimen (No. 2312) killed on the 1st of May, and said to have been a breedingbird, still retains some of the feathers of the winter-plumage.

[Speke's White-winged Whydah was plentiful on the plains around the south end of Ruwenzori, but was not met with on the mountains. $-R . B . W$.

\section{Spermestes cucullatus Swains.}

Spermestes cucullatus Reich. Vög. Afr. iii. p. 149 (1904); Shelley, B. Afr. iv. p. 167 (1905).

a. o . 80 miles W. of Entebbe, $3500 \mathrm{ft} ., 1$ st Dec. [No. 1024. D. C.]

$b-h$. of 우 et $\delta$ 우 imm. Mubuku Valley, E. Ruwenzori, 5500-6000 ft., 8th-21st Feb. d.

$$
\text { d. } d .
$$

[Nos. 148, 149. R. E. D. ; 1242, 1243, 1244, 1245, 1246. D.C.]

$i-y$. o 우 et of imm. Mubuku Valley, E. Ruwenzori, 5500-7000 ft., 4th-2Ist

March. [Nos. 186, 201. R.E. D.; 1336, 1337, 1343, 1344, 1345, 1355, 1350 d. 1365 ,

1393, 1394, 1398. D. C. ; 3201, 3232, 3234.R.B.W.]

Adult male and female. Iris dark brown or dark hazel; upper mandibles black, lower blue-grey; feet dark brown or blackish.

[Swainson's Bronze Mannikin was found on Ruwenzori up to an altitude of $7000 \mathrm{ft}$. It was not met with there during the months of December and January, but between February and April, when the millet was ripe, it appeared in great numbers, usually in small flocks of from ten to twenty individuals. $-R . B . W$.

SPERMESTES POENSIS (Fraser).

Spermestes poensis Reich. Vög. Afr. iii. p. 152 (1904); Shelley, B. Afr. iv. p. 164 (1905); Grant, Ibis, 1908, p. 271 [Upper Congo].

Spermestes poensis stigmatophora Reich. t. c. p. 153 (1904).

Spermestes stigmatophorus Hartert, Nov. Zool. vii. p. 4 l (1900) [Ituri Forest]; Jackson, Ibis, 1906, p. 562.

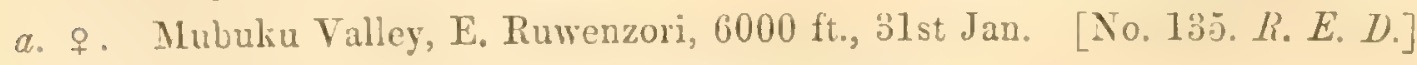




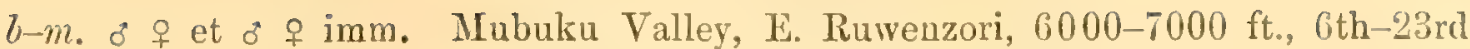
March. [Nos. 1299, 1300, 1328, 1341, 1377, 1378, 1379, 1389, 1415. D. C.; 3215 , 3231. R. B.W.]

n, o. $\delta$ ㅇ. Mawambi, E. Congo Forest, $2500 \mathrm{ft} ., 30$ th Oct. [Nos. 576, 577. R. E. D.]

Adult male and female. Iris dark brown or dark hazel; bill blue-grey or slatecolour ; feet dark brown or black.

According to Dr. Reichenow, these birds should be separated from typical S. poensis under the name S. p. stigmatophora Reichenow, but I agree with Captain Shelley and consider that it is not possible to recognize more than one form. Specimens from Fernando Po, Cameroon, \&c. are precisely similar to those collected by the present expedition.

[The Southern Black-and-Thite Mannikin was met with on Ruwenzori up to an altitude of about $6500 \mathrm{ft}$, where the forest commences. It was not seen during the months of December and January, but was numerous from February till April.R. B. W.]

\section{Prtelia belli Grant. (Plate XI. fig. 4, ơ .)}

Pytilia melba Reich. Vög. Afr. iii.p. 163 (1904) [part.].

Pytelia melba Shelley, B. Afro iv. p. 273 (1905) [part.].

Pytelia belli Grant, Bull. B. O. C. xxi. p. 14 (1907) [S.E. Ruwenzori]; id. Ibis, 1908, p. 274 [N.W. of Lake Tanganyika].

a-c. o ㅇ. Mokia, S.E. Ruwenzori, $3400 \mathrm{ft}$., 25th-30th April. [Nos. 1460. D. C.; 3272, 3282. R. B. W.]

d-n. of . Mokia, S.E. Ruwenzori, $3400 \mathrm{ft} ., 2 \mathrm{~d} d-26 \mathrm{th}$ May. [Nos. 291, 305, $37 \tau^{*}$. L. E. D. ; 1476, 1564, 1581, 1589 *. D. C. ; 2340, 2347, 2373. G. L. $]$

$o, p$. o 오. Mokia, S.E. Ruwenzori, 3400 ft., 26th June. [Nos. 1692, 1693. D. C.]

The male of this species differs from the male of $P$. melba (Linn.), which it resembles in the darker markings of the breast and belly, in having the grey of the cheek extending beneath the eye to the lores; and the red of the throat continued over the greater part of the chest, of which only the base is yellow. Iris reddishbrown; bill red; feet brown. Total length ca. 4.8 inches; wing 2.2 ; tail 1.95 ; tarsus $0 \cdot 7$.

The female has the breast darker grey than in the female of $P$. melba and the markings of the underparts, especially on the sides and flanks, darker. Iris hazel or

$$
\text { * Iypes of the species. }
$$


reddish-brown; upper mandible black, lower pink, reddish-brown or dull red; feet brown. Total length ca. 4.6 inches; wing 2.25 ; tail 1.9 ; tarsus 0.65 .

The under tail-coverts in the ten adult males of $P$. belli display great variation, and we find every intermediate stage between birds in which these feathers are uniform buff and those in which they are strongly marked with transverse bars of black. Mr. D. Garruthers procured a male of this form from the north-western shore of Lake Tanwanyika, $3000 \mathrm{ft}$, in which the bars on the under tail-coverts are fairly well markerl. 'l'here are also male examples in Mr. Jackson's collection from Kibwesi, in Ukamba, and Lake Albert, and there is a specimen in the British Iuseum procured by Emin at Kibiro on Lake Albert.

This species is easily distinguished from the two nearly allied forms, viz.: $P$. melbu (limm.) from South Africa, and $P$. soudanensis Sharpe ( $=P$. affinis Elliot), which ranges from the White Nile to Lado and through Somaliland as far south as Lamu. It is more distantly related to $P$. jessei Shelley, which inhabits Northern Abyssinia, and to $I^{\prime}$. citerior Strickl., which ranges from the White Nile into Senegambia.

As the key given by Captain Shelley [cf. Bull. B. O. C. xiii. p. 76 (1903)] for that section of the genus Pytelia which includes $P$. melba and its nearest allies does not seem satisfactory and does not include $P$. belli, I append the following :-

1. Chest orange-yellow; some red on the head.

a. Feathers of the upper breast blackish, conspicuously marked with twin-spots of white; upper tail-coverts dull crimson; lower part of the chest dull orange-yellow.

$n^{2}$. Scarlet of throat not extending over the chest.

$a^{2}$. Sides and flanks more or less ocellated with white like the breast, and not conspicuously barred; under tail-coverts without transverse bars . . . . . . . . . P. melba $\delta$.

$b^{2}$. Sides and flanks conspicuonsly and widely barred with black and white; under tail-coverts with indistinct dusky bars . . P. soudanensis of.

b. Searlet of throat extending over the greater part of the chest, only the base of which is dull orange-yellow . . . . . . . P. belli of.

b. Feathers of the upper breast with narrow dark markings forming either cross-bars or imperfect ocelli; upper tail-coverts bright scarlet; chest bright orange-yellow.

b. Feathers of the breast and flanks with narrow black bars . . P. citerior 8 .

$c^{2}$. l'eathers of the breast and Hanks more or less ocellated . . . P. jessei on.

I good many examples of Bell's Pytelia were net with in the acacia-forest on the platins around the south end of Ruwenzori. A nest was found placed in a low acacia-bush about 18 inches from the ground. It was domed and composed 
of fine grass and the down of some flower; the entrance was a small hole on unc silte close to the top. Unfortunately one of the birds was shot before any eggs had been laid.- $R . B . W$.

Nigimta fusconota Fraser.

Nigrita fusconvta Reich. Vög. Afr. iii. p. 168 (1904); Shelley, B. Afr. iv. p. 138 (1905).

a. ․ 10 miles N.W. of Fort Beni, Semliki Valley, $3000 \mathrm{ft}$, 10 th Aug. [No. 500. R. E. I. .]

Iris dark brown: bill and feet black.

This bird, which was shot in a forest-clearing, was breeding. It has the underparts somewhat greyer than in most of the specimens in the British Museum from Fernando Po, Cameroon, \&c., but one male specimen from Cameroon is similar in this respect. As regards the colour of the upperparts, the back is of a rather darker shade of brown than is to be found in any of the birds before us.

Nigita luteifrons Verreaux.

Nigrita luteifrons Reich. Vög. Afr. iii. p. 168 (1904) [part., nec Fernando Po]; Shelley, B. Afr. iv. p. 146 (1905) [part.].

a. $\delta^{\pi}$. Mawambi, E. Congo Forest, $3000 \mathrm{ft} ., 22 \mathrm{nd}$ Oct. $\quad[$ No. 3640. R. B. W.]

Iris light brown; bill black; feet light brown.

This specimen agrees with typical male examples from Gaboon, Cameroon, \&c., but is distinctly smaller, especially as regards the bill, than male birds collected by Mr. E. Seimund at Fernando Po. 'These latter have the golden-buff colour on the forehead brighter and extending further back over the crown, and the wing longer. while they are altogether somewhat larger birds. I have named this insular form N. alexanderi, after Mr. Boyd Alexander, who obtained examples of it during his cxpedition to Fernando Po in 1902.

The species has been described as follows:-

Nigrita alexanderi Grant.

Nigrita luteifrons Alexander (nec Verreaux), Ibis, 1903, p. 350.

Nigrita alexanderi Grant, Bull. B. O. C. xxi. p. 16 (1907).

Adult male. Similar to $N$. luteifrons, but larger and with a longer, stonter bill; the golden-buff on the forehead extending backwards over the crown to behind the cyes. Iris black; bill black; legs and feet flesh-colour. Total length 4.4 inches; culmen $0 \cdot 33-0 \cdot 35$; wing $2 \cdot 3-2 \cdot 4$; tail $1 \cdot 6$; tarsus $0 \cdot 6$.

Adult female. Similar to the female of $\boldsymbol{N}$. luteifrons, but rather larger. Wing $2 \cdot 3$ inches. 
'l'he following is a comparative table of measurements :-

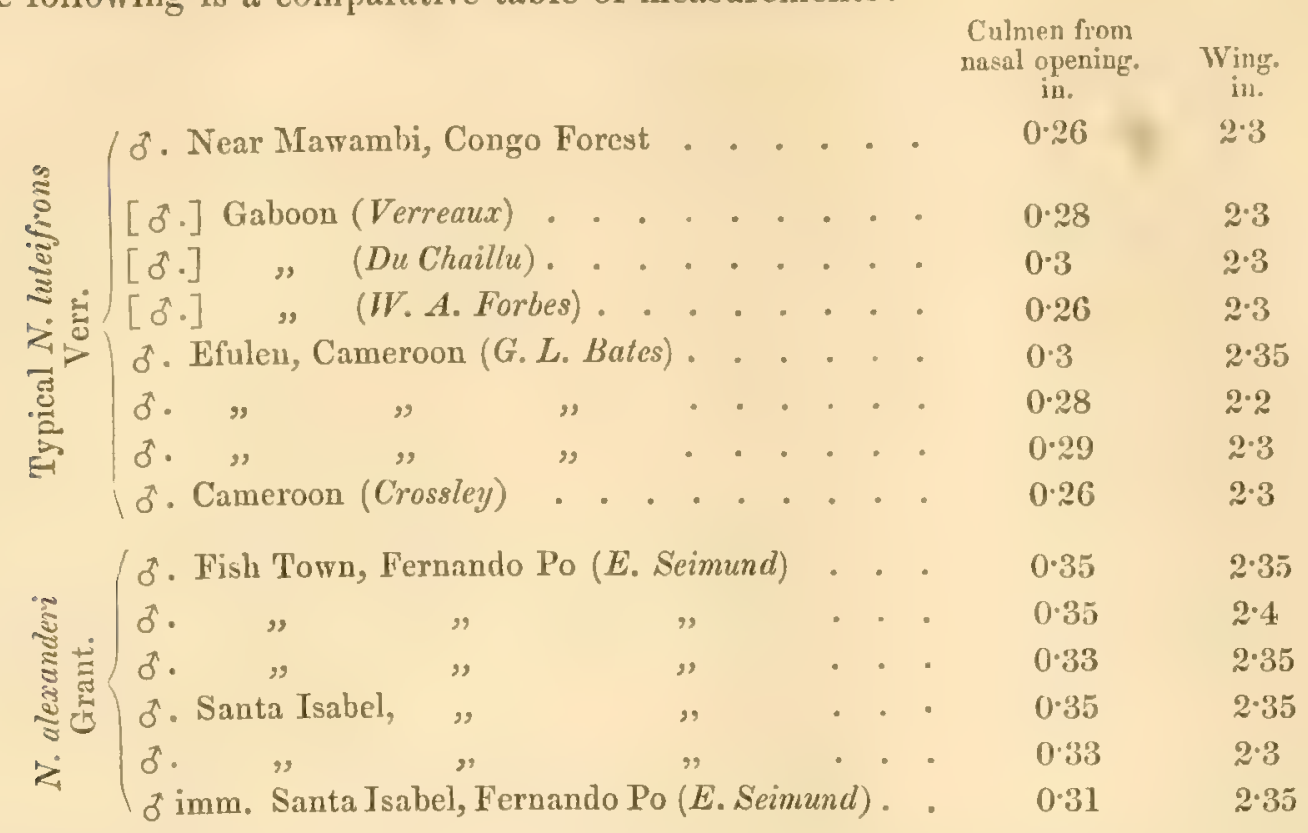

[A single example of the Pale-fronted Negro-Finch was obtained in a clearing in the Congo Forest near Mawambi.-R. B.W.]

\section{Nigrita Canicapilla (Strickl.).}

Nigrita canicapilla Reich. Vög. Afr. iii. p. 170 (1904); Shelley, B. Afr. iv. p. 141 (1905).

a. 8. Fort Beni, Semliki Valley, $3000 \mathrm{ft.}$. 21st July. [No. 2419. G. L.]

Iris orange; bill and feet black.

'The most easterly localities hitherto recorded for Strickland's Negro-Finch are the Aruwimi River (Jameson) and Kibonge (Bohndorff), both about 350 miles to the west of Fort Beni.

The male from Fort Beni, though somewhat smaller than typical examples of N. canicapilla from Fernando Po, especially as regards the size of the bill, does not ippear to be separable from them. 'The wing measures 2.55 and the tail 1.8 inches.

Nigrita SCHISTACEA Sharpe.

Nigrita schistacea Sharpe, Ibis, 1891, pp. 118, 251 ; Reich. Vüg. Afr. iii. p. 169 (1901); Shelley, B. Afr. iv. p. 145 (1905).

Nigrita sparsimguttata Reich. Vög. Afr. iii. p. 170 (1904).

Nigrita diabolica Jackson (nec Reich. \& Neumann), Ibis, 1906, p. 562 ['Toro ; Ruwenzori].

1. 0. 40 miles W. of Entebbe, $3500 \mathrm{ft.}, 27$ th Nov. [No. 11. R. E. D.]

7, c. of. 100 miles W. of Entebbe, $4000 \mathrm{ft}$. , 6th Dec. [Nos. 1039. D. C.; 3033. R. B. W.] 
d, e. o q. Mpanga Forest, Fort Portal, 5000 ft., 20th Sept. [Nos. 543, 544. R. E. D.]

f. o. Mubuku Valley, E. Ruwenzori, $6000 \mathrm{ft}$, 11th Jan. [No. 83. R. E. D.]

Iris orange, light brown, or dark hazel; bill black; feet dark brown or black.

Captain Shelley is no doubt correct in assuming that $N$. sparsinguttatu Reichenow is synonymous with the present species.

Immature examples have the whole of the upperparts uniform dark grey; subsequently the black on the forehead is assumed, then the grey on the rump, and the white band bordering the black forehead and sides of the head, as well as the white spots on the lesser and median wing-coverts, make their appearance.

[Jackson's Negro-Finch was met with here and there throughout the journey, from Victoria Nyanza to Ruwenzori, where it was found up to an altitude of $7000 \mathrm{ft}$ R. B.W.]

Nesocharis ansorgei (Hartert)。 (Plate XI. figs. 1, ð; ; 2, ‥)

Pytelia ansorgei Hartert, Bull. B. O. C. x. p 26 (1899) [Luimi (Wimi) R., Toro]; id. Nov. Zool. vii. p. 42 (1900); Neumann, Bull. B. O. C. xxiii. p. 47 (1908) [Lake Kivu].

Cryptospiza ansorgei Reich. Vög. Afr. iii. p. 175 (1904).

Chlorestrilda ansorgei Shelley, B. Afr. iv. p. 177 (1905).

Chlorestrilda capistrata Shelley, t. c. p. 177 [part., Meswa and Buguera (Emin)].

a. 8. Mpanga Forest, Fort Portal, $5000 \mathrm{ft.,}$ 18th Sept. [No. 534. R. E. D.]

A single male example of this rare and very beautiful little Waxbill was procured by Mr. Dent. I have compared it with the type-specimen, which was obtained by Dr. Ansorge on the Luimi River in Toro, and which has been sent me by Mr. Walter Rothschild for comparison.

I quite agree with Capt. Shelley that the present species cannot be placed in either of the genera Pytelia or Cryptospiza, both on account of its Bullfinch-like bill and for other rensons. He therefore created the genus Chlorestrilda, making C. ansorgei the type, but he overlooked the fact that the present species was obviously co-generic with Nesocharis shelleyi Alexander, a highland species from Fernando $P_{0}$ [cf. Bull. B. O. C. xiii. p. 48 (1903)], and with N. capistrate (Hartl.) $[=N$. sharpii (Nicholson)], which ranges from Senegambia to Dahomey.

The type-specimen of $N$. ansorgei, a male in very poor condition, was described by Dr. Hartert as having the "sides of the chest golden-olive," but, as is shown by the beautifully prepared skin in the present collection, this colour extends across the entire chest in a wide band.

Two adult males and a female were also procured by Mr. Jackson's collectors in the Kibera Forest, 'Toro, where the species was said to be plentiful. 'l'he female, which is figured on Plate XI. fig. 2, differs from the male in having the chest grey 
like the rest of the underparts. It closely resembles the type-also a fenale-of I. shelleyi Alexander, but is much larger and has a much stronger bill.

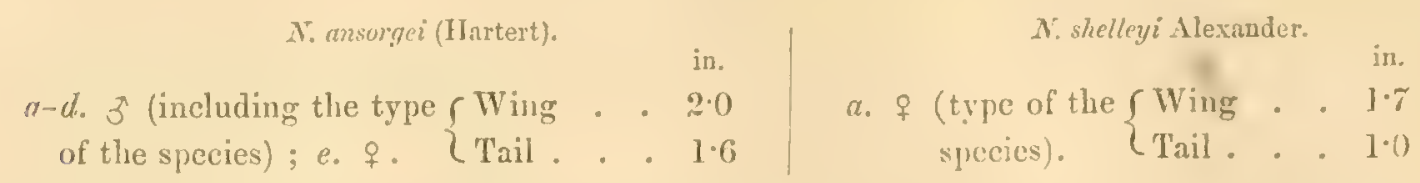

['The only example of Ansorge's Olive-backed Waxbill met with by the Expedition was procured in the Mpanga Forest, to the east of Ruwenzori. It was shot by IIr. R. E. Dent in the top of a tall tree.-R. B. II.]

Cryptospiza oculatis Sharpe.

Cryptospiza ocularis Sharpe, Bull. B. O. C. xiii. p. 8 (1902): Jackson, Ibis, 1906, p. 56:; Grant, Bull. B. O. C. xix. p. 42 (1907); id., Ibis, 1908, 1. 2\%0 [Mufumbiro].

1, b. \&. Mubuku Valley, E. Ruwenzori, $6000 \mathrm{ft}$., 2Sth Dec. [Nos. 1065. D. C.; :305. R. B. W.]

$c-f$. o f. Mubuku Valley, E. Ruwenzori, $6000 \mathrm{ft}$, 20th-31st Jan. [Nos. 128.

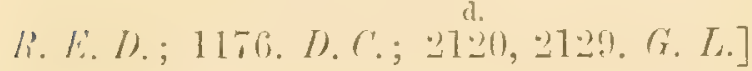

g-l. of $q$ et $q$ imm. Mubuku Valley, E. Ruwenzori, 6000-0500 ft., 1st-24th Feb. [Nos. 171. R. E. D. ; 2132, 2134, 2135, 2136. G. L.]

$m-t$. of $q$ et $\sigma^{*}$ o imm. Mubuku Valley, E. Ruwenzori, $7000 \mathrm{ft}$., 11th-19th March. [Nos. 1320, 1323, 1324, 1325, 1376. D. C. ; 2189 , G. L. ; 3203, 3230. R. B. W. ]

Adult male and female. Iris dark brown or aark hazel; bill black; feet brown or dark brown.

Is already pointed out, this species has been united with C. reichenowi Martlaub by Dr. Reichenow, but it is really a distinct form.

Sharpe's Crimson-wing was met with on Ruwenzori at an altitude of between 6000 ind $7000 \mathrm{ft}$., and, like most of these small Weaver-Finches, frequents the rough country below the forest-line, especially old sites of cultivation and crops of millet. 'This wpecies was never seen in large flocks as was the case with Spermestes cucullatus and $\therefore$ poensis. $-R . B . H$.

Cryptospiza salvadori Reichenow. (Plate XI. fig. 3, ơ.)

Cryptospiza salvadorii Reich. Vög. Afr. iii. p. 174 (1904) [part.]; Shelley, B. Afr. iv. p. 27 z (1905); Grant, Bull. 13. O. C. xix. p. 42 (1907).

$a-k$. o o f et $q$ imm. Mubuku Vallcy, L. Ruwenzori, 6000-7000 ft., 11th-19th March. [Nos. 203. R. E. D. ; 1321, 1322, 1353, 1375. U. C.; 2202, 2210. G. L.; $\because 0104,3211,3212 . R . T . W$. 
l. o . Butagu Valley, West Ruwenzori, $7000 \mathrm{ft.,}$ 1st Aug. [No. 2444. G. L.]

Iris dark brown; eyelids red in the male; bill black; feet brown or dark brown.

As already briefly noted (vide suprò, Bull. B. O. C.), Salvadori's Crimson-wing is at very distinct species from $C$. australis Shelley, from Nyasaland, although Dr. Reichenow has included the latter under the present heading.

C. australis is an altogether much darker bird than C. salvadorii.

The British Museum possesses six examples of $C$. australis, of which three, though apparently fully adult, differ somewhat from one another in plumage and are somewhat puzzling. 'The three adult examples are as follows:-

$a$. [Sex not ascertained.] Milanji Plateau, $6000 \mathrm{ft} ., 2 \mathrm{nd}$ Nor.

$b$, c. ㅇ. . Chiradzulu, July. (Specimen " $b$ " is the type of the species.)

These have the bill entirely black and the underparts brown, tinged with olive.

Specimen " $a$ " has some of the feathers across the upper mantle tipped with dull crimson, forming an irregular band.

Specimen " $c$ " has a number of small dull crimson feathers about the base of the bill.

Without additional material it is impossible to ascertain the cause of these differences, as all three birds appear to be fully adult.

The three remaining examples are no doubt immature:-

d. ㅇ. Kombi, Masuka range, $7000 \mathrm{ft}$., July.

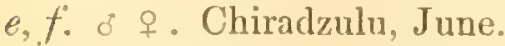

In " $d$ " the bill is black as in the adult; in " $e$ " and " $f$ " the base of the upper mandible is brownish and the basal part of the lower mandible pale yellowish-horncolour.

All three immature specimens have the underparts paler than in the adults, the brown plumage being largely mixed with olive.

Specimens of $C$. salvadorii from Ruwenzori agree perfectly with the birds procured by Doherty on the Kikuyu Escarpment.

[Salvadori's Crimson-wing was found on Ruwenzori at an altitude of between 7000 and $8500 \mathrm{ft}$. This species is very similar, both in habits and appearance, to $\therefore$ ocularis, but is less numerous and found at rather higher altitudes. It was seen on some of the open ferny ridges among the forest at $8500 \mathrm{ft} .-R . B . W$.

Criptospiza jacksoni Sharpe.

Cryptospiza jacksoni Sharpe, Bull. B. O. C. xiii. p. 8 (1902) ; leich. Vüg. Afr. iii. p. 17.

(1904) ; Shelley, B. Afr. iv. p. 280, pl. xxxv. fig. 2 (1905); Jackson, Ibis, 1906, p. 563.

a-d. ơ. Mubuku Valley, E. Ruwenzori, 6000 ft., 28th-30th Dec. [Nos. 49, 50, 6. R. E. D. ; 2038 . G. L.]

VOL. XIX.-PAIT IF. No. 40.-March, 1910. 
$e-h$. o ㅇ. Mubuliu Valley, E. Ruwenzori, 6000-7000 ft., 15th-19th Jan. [Nos, 10.

R. E. D. ; $1153,1154,1169$. D. C. $]$

$i, k$. $\quad$ et $\delta \mathrm{imm}$. Mubuku Valley, E. Ruwenzori, $6000 \mathrm{ft}$., 1st \& 8th Feb. [Nos. 2133. G. L.; 3153. R. B. IV.]

l-s. ơ ㅇ. Mubuku Valley, E. Ruwenzori, 6500-7000 ft., 5th-17th Mar. [Nos. 202. R. E. D. ; 1295, 1326, 1330, 1331. D. C.; 218s, 2211. G. L.; 3210. R. B. IV.]

Iris dark brown or dark hazel; bill and feet black.

The female of Jackson's Crimson-wing has not previously been described, but there is a series of ten adult males and seven adult females in the present collection, which shows that the latter differ in coloration from the former in the following particulars :-

Males.
Dark crimson of the crown extending
nearly to the occiput, only the middle
feathers of the hind crown being grey.
Sides of the head dark crimson and ex-
tending in a large patch behind the
eye on to the sides of the neck.

Grey band across the hind-neck more or less interrupted by the dark crimson sides of the head.
Females.

Hind part of the crown with the sides crimson, and the whole of the middle part grey like the hind-neck.

Sides of the head bright crimson and restricted to a large patch surrounding the eye, not extending on to the sides of the neck.

Grey band across the hind-neck wider and not interrupted.

An immature male differs from the adult in having the head and neck entirely grey without any trace of crimson. The crimson of the back, rump, upper tail-coverts, and flanks is duller in tint, and the coloured tips of the feathers are much narrower, so that their grey bases are visible and produce a mottled appearance.

[This species was met with on Ruwenzori at an altitude of between 6000 and S500 ft. It appeared to be a semi-forest bird, and, though it frequented the adjacent millet-crops and rough grass-country, on being disturbed usually disappeared into the forest. It was often met with among the undergrowth, in the darkest parts of the forest, far from the outskirts. $-R . B . W$.

\section{Cryptospiza shelleyi Sharpe.}

Cryptospiza shelleyi Sharpe, Bull. B. O. C. xiii. p. 21 (1902) [Ruwenzori]; Shelley, B. Afr. iv. p. 280, pl. xxxv. fig. 3 (1905); Jackson, Ibis, 1906, p. 563.

The type of this species was presented to the British MLuseum by Mr. F. J. Jackson. A single adult male example was procured by Mr. Geoffrey Archer on the 22nd of 
February, 1902, and is said to have been obtained on Ruwenzori, but the exact locality is not recorded. It was not met with by the members of the Expedition.

ESTRILDA MINOR (Cab.).

Estrilda astrild minor Reich. Vög. Afr. iii. p. 180 (1904) [part.].

Estrilda minor Shelley, B. Afr. iv. p. 198 (1905); Jackson, Ibis, 1906, p. 564. [Toro]; Grant, Ibis, 1908, p. 275 [Mufumbiro; N. of Lake Tanganyika].

a. o. 80 miles W. of Entebbe, $3500 \mathrm{ft}$., 1st Dec. [No. 1025. D. C.]

b-d. of et imm. 100 miles W. of Entebbe, $4100 \mathrm{ft}$., 5 th \& 6 th Dec. [Nos. 1036 , 1037, 1038. D. C.]

$e-g$. o et o imm. Mubuku Valley, E. Ruwenzori, $5000 \mathrm{ft}$, 23rd \& 28th March. [Nos. 2235. G. L. ; 3264, 3265. R. B. I . . ]

h, i. o 9. Mokia, S.E. Ruwenzori, $3400 \mathrm{ft} ., 14$ th May. [Nos. 1556, 1557. D. C.]

Adult male and female. Iris hazel, dark chestnut, or dark brown; bill red; fect varying from brown to blackish.

[The Lesser Waxbill was not met with on Ruwenzori above an altitude of $5000 \mathrm{ft}$., but was not uncommon on the dry plains round the south end of the range.R. B. H.]

\section{Estrilda paludicola Heugl.}

Estrilda paludicola Heuglin, J.f. O. 1863, p. 166; 1868, p. 9, pl. 1. fig. 2 [Gazelle R.]; Hartert, in Ansorge, Under Afr. Sun, App. p. 346 (1899) [Unyoro; Uganda]; Reich. Vüg. Afr. iii. p. 184 (1904); Shelley, B. Afr. iv. p. 214 (1905) [part.].

a. b. o f. 60 miles N. of Fort Beni, Semliki Valley, 2500 ft., 16th Aug. [Nos. 1789, 1790. D. C. ]

Iris and bill red; feet dark brown.

The pair of birds obtained by Mr. Carruthers to the north of Fort Beni are undoubtedly referable to Heuglin's Pale Waxbill, first described from the Gazelle River. The three birds procured by Mr. F. J. Jackson's collectors in 'Toro and referred to the present species by Captain Shelley in his work on 'The Birds of Africa' have been incorrectly identified, and are really referable to E. roseicrissa Reichenow, having the characteristic umber-brown crown, of the same colour as the back.

I have seen a fairly large series of examples of both the present species and E. roseicrissa, including nine specimens of the former from the Tring Museum. From these it is evident that the rosy flanks are equally characteristic of both species, and are probably due partly to age and partly to season.

Immature birds of this species are apparently hardly to be distinguished from immature specimens of $E$. roseicrissa, the crown being of much the same brown colour as the back. 
The localities from which undoubted specimens of $E$. paludicola have been examined are as follows:--Lado, 'lingasi, 60 miles north of Fort Beni, Semliki Valley, Unyoro, Lintebbe, and Kavirondo. 'The species has also been obtained in Angola by Mr. C. H. l'emberton.

[Not uncommon in the clearings in the Eturi Forest between Fort Beni and limu. $-R . B . W$.

\section{Kstrilda roseichissa Reichenow.}

Estrilda roseicrissa Reich. Vög. Afr. iii.p. 184 (1901); Shelley, B. Afr. iv. p. 215 (1905); Grant, Ibis, 1908, p. 276 [Lake Kivu].

a, b. of imm. 80 miles W. of Entebbe, 3700-3800 ft., 2nd Dec. [Nos. 22. R. E. D.; 3024. R. B. W.]

c. o. Mohia, S.E. Ruwenzori, $3400 \mathrm{ft}$, 26th April. [No. 1436. D. C.]

d, e. of et $\delta$ imm. Mokia, S.E. Ruwenzori, $3400 \mathrm{ft}$. 2nd June. [Nos. 3442, 3443. R. B.W.]

Adult male. Iris reddish-brown; bill coral-red; feet black.

Adult female. Iris dark orange; bill pink; feet dark brown.

'The specimens mentioned above are no doubt typical examples of Emin's Rosyflanked Waxbill, the type of which was procured at Bukoba on the west shore of Victoria Nyanza. I have recently recorded and made notes on an adult pair sent by Ir. Carruthers from Lake Kivu.

'The immature specimens in the present collection differ from the adults in having the bill dusky along the culmen and cutting-edges of the mandibles; the back uniform brown, without any trace of fine dusky cross-bars, and the pink wash on the flanks and vent barely indicated.

I have examined spécimens of E. roseicrissa from Toro, Bukoba, S.E. Ruwenzori, and Lake Kivu.

[This little Waxbill was plentiful on the plains round the south end of Ruwenzori, but was not met with on the mountains. $-R . B . W$.

Fstrildi nonnula Hartl.

Estrilda nonnula Reich. Vög. Afr. iii. p. 188 (1904); Shelley, 'B. Afr. iv. p. 226 (1905); Jackson, Ibis, 1906, p. 564 [Ruwenzori].

a. o. 90 miles W. of Entebbe, $4000 \mathrm{ft}$, 4 th Dec. [No. 3026. R. B. W.]

b-d. d. Mubuku Valley, E. Ruwenzori, $6000 \mathrm{ft.,} 28$ th \& 30th Dec. [Nos. 1061, d.

1062, 1072. D. C. $]$

$\ell, f$. o et o imm. Mubuku Valley, E. Ruwenzori, $6000 \mathrm{ft}, 6$ th \& 15 th Jan. [Nos. 73 . R. L. D.;2085. G. L.]

g. 3. Mubuku Valley, E. Ruwenzorj, $6000 \mathrm{ft}, 22 \mathrm{nd} \mathrm{Feb.} \mathrm{[No.} \mathrm{125̃6.} \mathrm{D.} \mathrm{C.}]$ 
$h-r$. of et o imm. Mubuku Valley, E. Ruwenzori, 6000-7000 ft., 11th-16th March. [Nos. 1332, 1333, 1339, 1354. D. C. ; 2203. G. L.; 3200, 3223, 3224, 3228, 3229. R. B. IT.]

Adult male. Iris dark brown or dark hazel; bill black and red; feet black.

Curiously enough, the above series of seventeen specimens does not include a single adult female; the latter differs from the male in having the underparts greyer.

[Hartlaub's Black-crowned Waxbill was met with everywhere throughout the journey, except in the Eturi Forest. It was a common species on the mountains up to an elevation of $7000 \mathrm{ft}$., and in company with many other species of small WeaverFinches was to be seen in thousands feeding upon the native crops of millet.R. B.W.]

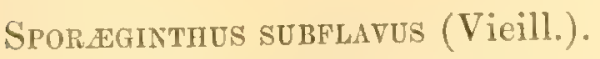

Estrilda subflava Reich. Vög. Afr. iii. p. 186 (1904) [part.]; Shelley, B. Afr. iv. p. 207 (1905), Sporceginilus subflavus Grant, Ibis, 1908, p. 275 [Mufumbiro Volcanoes].

a. ‥ N. Ruwenzori, $3500 \mathrm{ft}$, 19th Aug. [No. 3551. R. B. W.]

b. o. Lower Semliki Valley, $2500 \mathrm{ft}$., 11th Oct. [No. 3625. R. B.W.]

Adult male. Iris scurlet; bill scarlet; feet light brown.

Adult female. Iris bright orange; bill pink; feet pale flesh-colour.

The male $(b)$ of the Northern Zebra-Waxbill is a very brilliantly coloured specimen, rather ınore so than any example in the British Museum.

[The species was met with only to the north-west of Ruwenzori, between the Semliki River and Irumu.-R. B.W.]

LAgonosticta rUberrima Reichenow.

Lagonosticta brunneiceps ruberrima Reich. Vög. Afr. iii. p. 198 (1904).

Lagonosticta brunneiceps Shelley, B. Afr. iv. p. 258 (1905) [part.].

Lagonosticta ruberrima Jackson, Ibis, 1906, p. 564 [Toro]; Grant, Ibis, 1908, p. 2r1 [S.W. Uganda; Lake Edward; Lake Tanganyika].

a. o . Mokia, S.E. Ruwenzori, $3400 \mathrm{ft} ., 26 \mathrm{th}$ April. [No. 3284. R. B.W.]

b-i. of ot o imm. Mokia, S.E. Ruwenzori, $3400 \mathrm{ft.}$, 2nd-26th May. [Nos. 1562, 1563. D.C.; $3309,3336,3350,3366,3416,3421, R . B . W$.

$k-m$. of of et o imm. Mokia, S.E. Ruwenzori, $3400 \mathrm{ft}$, 10th-25th June. [Nos. 1688. D. C. ; 3462, 3466.R. B.W.]

Adult male and female. Iris hazel, reddish-brown, or chestnut; bill pink or dull pink; feet brown or dark brown.

This darker Equatorial form of the Brown-capped Fire-Finch (L. brunneiceps Sharpe) appears to be a fairly well-marked form. I have already referred to it in the paper on Mr. Douglas Carruthers's collection published in 'The Ibis,' as quoted above. 
[A nest of this species was found on the plains at the south end of Ruwenzori $(3400 \mathrm{ft}$.$) . It was placed in a low fence surrounding a native garden, and was composed$ of small sticks, roots, and grass. It was partially domed and, on the 10th of June, contained three pure white eggs, which measure respectively $\cdot 55 \times \cdot 44, \cdot 54 \times \cdot 45$, and $.53 \times .44$ in. This bird often builds its nest in the thatch of native huts. $-R . M . I J$.]

\section{Lagonosticta rhodoparia Hengl.}

Lagonosticta rhodopareia Reich.Vïg. Afr. iii. p. 200 (1904); Shelley, B. Afr. iv. p. 250, pl. xxxiv. fig. I (1905); Jackson, Ibis, 1906, p. 565 [Toro]; Grant, Ibis, 1908, p. 272 [Mufumbiro Volcanoes; Lake Kivu].

Lagonosticta rubricata hildebrandti p. 167, and L.r. homatocephala, p. 168, Neumann, Orn. Monatsb. xv。 (1907).

Lagonosticta ugande Salvad. Boll. Mus. Torino, xxi. no. 542, p. 2 (1906) [Fort Portal].

a. o. 12 miles W. of Entebbe, $3500 \mathrm{ft}$, 24 th Nov. [No. 2004. G. L.]

7. ơ. Mubuku Valley, E. Ruwenzori, $6000 \mathrm{ft}$. 25th Jan. [No. 2113. G. L.]

c. o imm. Mubuku Valley, E. Ruwenzori, $6000 \mathrm{ft}$., 19th March. [No. 1380. D.C.]

Adult male. Iris dark brown; bill horn-blue or slate-blue; feet brown or black.

Immature male. Iris dark brown; bill blue-grey, black at the tip; feet dark brown.

I have already fully stated my reasons ('Ibis,' 1908, p. 272) for differing entirely from the conclusions recently arrived at by Prof. Neumann, and for regarding all the birds described under the above names as synonymous with $L$. vhodoparia Heugl. In the colour of the upperparts the type of that species closely resembles examples in the British Nuseum collected by Lord Lovat in Southern Abyssinia, and also birds from the Gessima River, Likipia, B.E. Africa. Lord Lovat's specimens were doubtfully referred to L. congica Sharpe (cf. 'Ibis,' $1900, p .127$ ), but whether the type of that species is merely an immature example of $L$. rhodoparia requires further confirmation.

[The Rosy Black-billed Fire-Finch was obtained near Entebbe, and two specimens were procured on the east side of Ruwenzori at an elevation of $6000 \mathrm{ft}$. in January and March. Possibly the species may be more numerous at some other season of the sear.- - R. B. W.]

Nisisna mans. Neumann. (Plate $\mathrm{X}$. fig. 4, o*.)

Neisna dufresneyi nyanse Neumann, J. f. O. 1905, p. 350.

Ncisna minima Grant, Bull. B. O. C.xvi. p. 117 (1906).

Neisna myansce Grant, Ibis, 1908, p. 274. [Mufumbiro Volcanoes; Lake Kivu].

a, b. o imm. Mubuku Valley, E. Ruwenzori, $6000 \mathrm{ft}$, 30 th Dec. [Nos. 1073, 10\%4. D. C.]

c.e. o et o $9 \mathrm{imm}$. Mubuku Valley, E. Ruwenzori, $6000 \mathrm{ft}$. 6th-29th Jan. [Nos. $1106 *$, 1175. L. C.; 2125. G. L. $]$ 
f. o imm. Mubuku Valley, E. Ruwenzori, $6000 \mathrm{ft}$, 6th Feb. [No. 3118. R. B. W.]

g-r. of $q$ et o o imm. Mubuku Valley, E. Ruwenzori, 6000-7000 ft., 14th-23̂rd March. [Nos. 1342, 1349, 1350, 13อ๋1, 1359*, 1390, 1391, 1396, 1397, 1413, 1414. D. C.]

This species is closely allied to $N$. quartinia (Bonap.), but somewhat smaller and has the middle of the belly more ochracenus. In one male example (No.1349) there is a distinct dull orange-scarlet patch on the middle of the upper breast. In the deeper colour of the belly it approaches $N$. kilimensis (Sharpe), but differs in having the throat and breast pearl-grey instead of smoky grey.

Iris dark brown or dark hazel; upper mandible black, lower red; feet dark brown or black.

The immature bird differs from the adult in having the back uniform olive, without any trace of the narrow dusky cross-bars which characterise the adult. Bill black, or with some red on the lower mandible; in other respects it resembles the adult.

When I described this species as new under the name $N$. minima, I was not aware that it had already been named by Professor Neumann. The type of $N$. nyansie, procured by Emin Pasha at Bukoba, on the western shore of Victoria Nyanza, is in the Berlin Museum.

[The Nyanza Waxbill was plentiful in the Toro district, around Fort Portal, and on the east side of Ruwenzori up to an altitude of $7000 \mathrm{ft}$, but was not met with below $5000 \mathrm{ft}$., where the land slopes down towards Lake George. It was particularly fond of the seeds of a large thistle which grows on the mountains. $-R . \mathrm{b} . \mathrm{H}$.]

VIDUA SERENA (Linn.).

Vicha serena Reich. Vög. Afr. iii. p. 217 (190t); Shelley, B. Afr. iv. 1. 16 (1905); Jackson, Ibis, 1906, p. 560 [Toro].

a. o. 30 miles W. of Entebbe, $3500 \mathrm{ft}, 26 \mathrm{th}$ Nov. [No. $3007 . R$. B. W. $]$

b. o. $120 \quad, \quad, 4200 \mathrm{ft}$, Sth Dec. [No. 1049. D. C.]

c-h. o 오. Mokia, S.E. Ruwenzori, $3400 \mathrm{ft}$., 9th-19th May. LNos. 1530, 1531, d.

$1567,1568,1590$ †. D.C.; $3442 . R . B . W$.

$i-n$. of $q$ et $q$ imm. Mokia, S.E. Ruwenzori, 10th-15th June. [Nos. 443, 444. d.

445, 453. R. E. D. ; 2403. G. L.]

o. o juv. Butagu Valley, W. Ruwenzori, $4000 \mathrm{ft}$, 20th July. [No. 2442. C. L.]

* Types of Neisna minima Grant.

+ No. 1590 , marked as a female, is almost ccrtainly an immature male; the middle tail-fathers are rery long, 8.1 inches, while the remainder of the plumage is much like that of the female. As a rule, the black plumage of the head and back is assumerl before the long tail-feathers appear. 
Adult male and female. Iris dark brown or dark hazel; bill scarlet or red; fect black.

Immature male. Iris dark brown; bill and feet brown.

TThe White-breasted Whydah was met with throughout the journey from Victoria Nyanza to the edge of the Eturi Forest. It was most amusing to watch the male of this species escorting his harem. In a very excited and fussy manner he would fly from bush to bush or hover around the females with a curious jumpy flight, all the time keeping up a continuous twittering and chirping. $-R . B . W$.

\section{Family FRINGILLID}

PAsser diffusus Smith.

Passer diffusus Shelley, B. Afr. iii. p. 251 (1902); Grant, Ibis, 1908, p. 279 [Upper Congo]. P'asser griseus Vicill. Nov. Dict. d'Hist. Nat. xii. p. 198 (1817) ; Reich. Vög. Afr. iii. p. 230 (1904).

Passer diffusus ugande and $P$. d.occidentalis Hartert, Nov. Zool. vii. p. 44 (1900).

a. o. 60 miles W. of Enteble, $3700 \mathrm{ft}$., 29th Nov. [No. 3015. R. B.W.]

b. ․ 130 miles W. of Entebbe, $4000 \mathrm{ft}$., 10th Dec. [No. 2028. G. L.]

c. ‥ Mubuku Valley, E. Ruwenzori, $7000 \mathrm{ft}$., 30 th Jan. [No. 2126. G. Is.]

d, e. o ㅇ. Mubuku Valley, E. Ruwenzori, $5000 \mathrm{ft} ., 22 \mathrm{nd} \&$ 23rd March. [Nos. 1405. D. C.; 2236. G. L. ]

f. $\sigma^{*}$. Mokia, S.E. Ruwenzori, $3400 \mathrm{ft}$., 30th April. [No. 2306. G. L.]

$g, h$. o et $\sigma^{*}$ juv. Mokia, S.E. Ruwenzori, $3400 \mathrm{ft}, 15 \mathrm{th}$ \& $22 \mathrm{nd}$ May. [Nos. 329, 353. R. E. D.]

i. o. Fort Beni, Semliki Valley, $3000 \mathrm{ft} ., 19$ th July. [No. 3504. R. B. W.]

Adult. Iris brown or reddish-brown; bill black; feet brown.

The specimens in the present collection lead me to believe that Captain Shelley may be right in uniting $P$. swainsoni (Rüpp.) (= Passer griseus abyssinicus Neum.) with $P$. diffusus Smith. Certainly the birds procured in the Mubuku Valley (specimens $c-e$ ) closely approach the Abyssinian form in the greyer colour of their underparts and in the absence of a distinct white patch on the throat. The male has the underparts grey as in $P$. swainsoni, but the two females have the belly white as in typical $P$. diffusus, and are only to be separated from that form by the colour of the throat, which, though somewhat paler than the cheeks, is not pure white. 'lhus we find that the birds from the Mubuku Valley $(5000-7000 \mathrm{ft}$.) agree with $P$. swainsoni from the highlands of Abyssinia, while the specimens from Entebbe, S.E. Ruwenzori, and Fort Beni do not differ from ordinary white-throated examples of $P$. diffusus.

The specimen from Fort Beni appears to be an old bird and has the top of the 
head very grey, most of the feathers being in worn plumage, in marked contrast to the reddish-brown mantle.

Dr. Reichenow thinks that the White-throated Sparrow should be known as Passer grisea (Vieill., 1817), and there can be no doubt that the description of "Fringilla grisea" agrees very well with examples of the present species; but as Vieillot states that the type came from the "United States," that it had a forked tail, and that its total length was only $4 \frac{3}{4}$ inches instead of 6 inches, I prefor to use the name given by Smith to the South African bird in 1836.

[The Common Grey-headed Sparrow was not found on Ruwenzori above an altitude of $7000 \mathrm{ft}$., and was rarely seen above $5000 \mathrm{ft} .-R . B . W$.

\section{Serinus iCterus.}

Serinus butyraceus Shelley, B. Afr. iii. p. 193 (1902).

Serinus icterus barbatus (Heugl.); Reich. Vög. Afr. iii. p. 2ّ 1 (1901).

Serinus icterus Grant, Ibis, 1908, p. 280 [Lake 'Tanganyika].

$a, b$. o et $q$ imm. 120 miles W. of Entebbe, $4000 \mathrm{ft}$., Sth Dec. [Nos. 37, 38. R. E. D.]

c,d. o ㅇ. Mokia, S.E. Ruwenzori, 3400 ft., 26 th April. [Nos. 3274, 3275. R. B.W.]

$\ell-l$. o ? . Mokia, S.E. Ruwenzori, $3400 \mathrm{ft} .3 \mathrm{rd}-22 \mathrm{nd} \mathrm{May.} \quad$ Nos. 278. R. E. D.; $1523,1524,1592,1593,1605$. D.C. ; 2370. G. L.]

$m, n . \delta^{*}$. Mokia, S.E. Ruwenzori, $3400 \mathrm{ft}$. 15th \& 16th June. [Nos. 455, 459. R. E. D.]

Adult male and female. Iris dark brown; bill brown or dark brown (two markerl black, R. E. D.) ; feet brown or dark brown.

The Common Yellow-fromed Canary was met with throughout the journey from Lake Victoria to Fort Beni in the Semliki Valley, but it was not met with on liuwenzori above an altitude of $6000 \mathrm{ft} .-R . B . W$.

\section{Serinus graueri flartert.}

Poliospiza striolata Jackson (nec Rüpp.), Ibis, 1906, p. 560 [Ruwenzori].

Serinus striolatus graueri Hartert, Bull. B. O. C. xix. p. 84 (1907).

Serinus graueri Grant, Ibis, 1908, p. 280 [Mufumbiro Volcanoes].

a-c. o f. Mubuku Valley, E. Ruwenzori, $6000 \mathrm{ft}$., $28 \mathrm{th}$ Dec. [Nos. 106:, 1064. D.C.; 2033.G.L.]

$d-l$. o ㅇ. Mubuku Valley, E. Ruwenzori, 6000-7000 ft., 1st-20th Jan. [Nos. 102. R. E. D. ; 1084, 1173. D. C. ; 2054, 2079, 2083, 2089. G. L.; 3065. R. B. IV.] $m, n$. o + . Mubuku V'alley, E. Rumenzori, 6000 and 10,500 ft., Sth \& 20 th Feb. [Nos. 163. R. Li. D.; j 155. R. B. W.]

Yol, xix.-Palt IV. No. 41.-Allarch, 1910. 
o-s. o 오 et imm. Mubuku Valley, E. Ruwenzori, 6000-7000 ft., 13th-21st March. [Nos. 1338, 1399, 1400. D. C.; 2201. G. L.; 3208. R. B.W.]

$t, u$. o imm. et + . Mubuku Valley, E. Ruwenzori, 10,000 and 13,200 ft., 3rd \& 5th April. [Nos. 1424.D.C.;3266.R.B.W.]

$v, w$. o 오. Butagu Valley, W. Ruwenzori, 7000 ft., 1st Aug. [Nos. 1767. D. C.; 3532. R. B.W.]

Adult male and female. Iris light brown or dark brown; bill brown or horn-colour; feet light or dark brown.

Dr. Hartert has separated the Streaked Seed-eater from Ruwenzori under this heading on account of its darker plumage. The upperparts are much darker brown than in S. striolatus (Rüpp.); the quills are margined on the outer web with olivebrown tinged with green, instead of yellowish-green; and the underparts are rufousbuff instead of whitish-buff.

The species was subsequently procured by Mr. Carruthers on the Mufumbiro Volcanoes.

Immature birds differ from the adult in having the underparts, especially the chin and throat, washed with yellowish, and the middle of the belly streaked with black like the rest of the underparts.

[Grauer's Streaked Seed-eater was found on Ruwenzori from an elevation of $5500 \mathrm{ft}$. up to $14,000 \mathrm{ft}$. It was most plentiful among the rough scrubby country just below the forest-line. A good many were also met with in the swampy valleys in the Treehath zone. $-R . B . W$.

SuRINus hilimexsis (Richmond).

Crithagra kilimensis Richmond, Auk, xiv. p. 155 (1897) [Kilimanjaro].

Serinus albifrons Shelley, B. Afr. iii. p. 210 [part.], pl. xxv. fig. 2 (1902).

Poliospiza albifrons Reich. Vög. Afr. iii. p. 257 (1902) [part.]; Jackson, Ibis, 1906, p. 559 [Ruwenzori].

a,b. ㅇ․ Mubuku Valley, E. Ruwenzori, $6000 \mathrm{ft}$, 30th \& 31st Dec. [Nos. 1076. D). C. ; 2040. G. $\left.L_{*}\right]$

c-f. o f. Mubuku Valley, E. Ruwenzori, 6000-7000 ft., 2nd-27th Jan. d.

[Nos. 2050, 2110, 2111, 2114.G.L.]

$g-i$. o $q$ et o imm. Mubuku Valley, E. Ruwenzori, 6000-\$000 ft., 21st-23rd Feb. [Nos. 2161, 2162, 2166. G. L.]

k. ơ. Mubuku Valley, E. Ruwenzori, $6500 \mathrm{ft}$. 8th March. [No. 1305. D. C.]

Adult male and female. Iris hazel or dark brown; bill brown, lighter at the base of the lower mandible; feet brown or dark brown.

The type-specimen of $S$ albifrons Sharpe was obtained at Kikuyu and is characterised 
by having a distinctly white forehead nearly $0.2 \mathrm{inch}$ in width. Two other specimens from Roromo, Kikuyu, as well as one from Nairobi and one from the Waso Nanyuki River, Western Kenya, agree with the type in having the forehead white.

In four males the measurement of the wing varies from 3.15 to 3.4 inches, and in one female it is $3 \cdot 2$.

Fifteen adult specimens of S. kilimensis, from the Mau Escarpment, Eldoma Ravine. and Nandi, have the forehead entirely brownish-black, with scarcely any trace of white, and are on the whole rather larger than typical examples of $S$. albifrons. In eight males the wing-measurement varies from 3.35 to 3.7 inches, and in seven females it varies from $3 \cdot 35$ to $3 \cdot 55$.

Two male specimens in the Jackson Collection from Mount Elgon (one somewhat immature) have the belly conspicuously washed with rufous-buff, and in this respect nearly resemble birds from Nandi, which have the belly brighter than in birds from the Eldoma Ravine and Mau Escarpment. The wings of these two specimens measure respectively $3 \cdot 6$ and 3.55 inches.

At Toro and on Ruwenzori a rather smaller-billed race is met with, and, like the bird found on the Mau Escarpment, has scarcely a trace of white on the forehead.

It will thus be seen that the form which ranges from Ruwenzori to the Mau Escarpment is different from typical $S$. albifrons from Kikuyu, and should no doubt bear the name of S. kitimensis (Richmond), with which I have identified it.

The immature bird agrees with the description of the young of $S$. albifrons given by Captain Shelley, but the throat is almost uniform black, with barely a trace of the whitish cross-bars characteristic of the adult.

[The Western Brown Canary was met with on liuwenzori from an altitude of 5500 feet up to 8500 feet; it was, however, a very rare bird, and was not met with anywhere else. $-R . B . W$.

Serinus sharpei Neumann.

Serinus sharpei Neumann, J. f. O. 1900, p. 287; Reich. Vög. Afr. iii. p. 266 (1904); Grant, Ibis, 1908, p. 280 [Mufumbiro Volcanoes].

Serinus shelleyi Neumann, Orn. Monatsb. xi. p. 184 (1903).

Serinus imberbis (Cab.); Shelley, B. Afr. iii. p. 203 (1902).

a. o. 150 miles W. of Entebbe, 5000 ft., 12th Dec. [No. 1055. D.C.]

b. $\sigma^{3}$. Mpanga Forest, Fort Portal, $5000 \mathrm{ft}$., 20th Sept. [No. 3586. R. B. W.]

c. f. Mubuku Valley, E. Ruwenzori, $6000 \mathrm{ft}$., 30 th Dec. [No. 57. R. E. D.]

d. 8. Mokia, S.E. Ruwenzori, $3400 \mathrm{ft} ., 19$ th May. [No. 2369. G. L.]

Adult male and female. Iris dark brown or dark hazel; bill brown, olive-brown, or horn-colour; feet brown or dark brown.

Serinus shelleyi Neumann bears a much closer relationship to $S$. sharpei Neumann $2 \mathrm{~T} 2$ 
than the latter does to S. sulphuratus (Linn.). A series of specimens can be laid out showing that the largest-billed example of the South African bird with a wing of about 3.3 inches intergrades more or less completely with the small-billed S. shelleyi with a wing of about $3 \cdot 0$ inches. I have examined typical examples of $S$. sulphuratus from South and South-east Africa as far north as Macamac, near Lydenburg, in the 'Transvaal; of S. sharpei from Lakes Naivasha and Nakuro and Eldoma Ravine, all to the east of Victoria Nyanza, and from Melsetter in. Northern Gazaland; and of S. shelleyi from Mount Eilgon, Entebbe, Mpanga Forest, Ruwenzori, Mulema, Nyasaland, and 'Tete, on the Zambesi.

The type of S. shelleyi is said by Prof. Neumann [cf. Orn. Monatsb. xi.p. 184 (1903)] to be in the Berlin Museum, and to have come from Katuro, Karagwe, to the west of Victoria Nyanza; but there is a specimen in the British Museum from Tete, procured by the Livingstone Expedition, which is marked in Prof. Neumann's writing as "Serinus shelleyi Neum. typus." This bird appears to be in rather abnormal plumage, having the dark markings on the head and upperparts nearly obsolete.

After examining all the material available I can only conclude that $S$. sulphuratus is barely separable from $S$. sharpei, and that $S$. shelleyi must be regarded as synonymous with the latter, or else as a very slightly smaller race. 'The comparative measurements of a number of specimens in which the sex has been properly ascertained is as follows :-

$$
\begin{aligned}
& \text { Serinus sharpei. } \\
& 6 \text { o . . . wing } 3 \cdot 15-3 \cdot 3 \text { in. } \\
& 5 \text { \&. . . . } 3 \cdot 1-3 \cdot 2,
\end{aligned}
$$

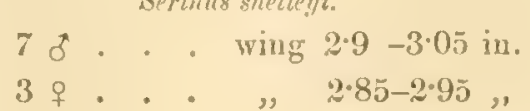

I may here remark that male examples of the large-billed form from Zululand differ considerably from Cape specimens, and have the green wash on the breast much reduced. They closely resemble $S$. sharpei, except as regards the size of the bill.

[A fer examples of Sharpe's Canary were seen in the acacia-country around the south end of Ruwenzori and again near Fort Portal, but they were rather uncommon.li. B. H.

\section{Chrysonitris frontalis (Reichenow).}

Spinus cilrinelloides frontalis Reich. Vög. Afr. iii. p. 275 (1901).

Cltrysomitris frontalis Grant, Ibis, 1908, p. 279 [Mutumbiro Volcanoes].

$a-f . \delta$ 우. Mubuku Valley, E. Ruwenzori, $6000 \mathrm{ft} ., 28 \mathrm{th}-31$ st Dec. [Nos. 1068, 1071, 1078, 1079. D.C.; 2031. G.L. ; 3059.R. B.W.]

g, h. o . Mubuku Valley, E. Ruwenzori, $6000 \mathrm{ft}$, 4th \& 30 th Jan. [No. 2128. G. L. 306s. R. B. W.] 
$i-l$. of $q$ et $q$ juv. Mubuku Valley, E. Ruwenzori, $6000 \mathrm{ft}$, 4th-24th Fei). [Nos. 170.R.E. D.; 2143. G. L.; 3154.R.B.W.]

$m-s$. of $q$ et $f$ imm. Mubuku Valley, E. Ruwenzori, 5000-7000 ft., 8th-24th March. [Nos. 222. R. E. D.; 1306, 1403, 1404. D. C. ; 2187, 2199. G. L.; 3206.R. R.W.]

t. ‥ Mubuku Valley, E. Ruwenzori, $7000 \mathrm{ft.,}$ 10th April. [No. 228. R. E. D.]

$u-w .0+$. Fort Beni, Semliki Valley, 3000 ft., 19th-23rd July. [Nos. 1727. D. C.; 2427, 2428. G. L.]

Adult male. Iris brown, dark brown, or hazel; bill brownish-horn-colour; fect brown. The blackish streaks on the back seem to vary considerably with age. In what appears to be the oldest male (No. 1403), with the brightest olive-yellow back. they are much reduced, taking the form of narrow shaft-streaks; while in a second male (No.3059), marked "breeding," the feathers of the upperparts are olive with black middles, producing a somewhat spotted appearance.

As the female of this species does not appear to have been described, I take this opportunity of characterizing it:-

Alult female. Differs from the female of C. citrinclloides (Riipp.) in having the yellow band across the forehead and the yellow eyebrow-stripes well developed and the underparts uniform yellow. In both these respects it resembles the male of $C$. frontalis, but is not quite so brightly coloured below, while the narrow black frontal band, black sides of the face and chin of the latter are absent, the lores and cheeks being olivegreen and the chin yellow.

Iris dark brown or hazel; bill brownish-horn, lighter on the lower mandible; feet brown or light brown.

Total length ca. 4.5 inches; culmen 0.55 ; wing 2.55 ; tail 1.8 ; tarsus 0.55 .

The young female is much browner than the adult and has the plumage of the underparts soiled yellow, with the chest, upper breast, sides, and flanks streaked with dusky.

[Reichenow's Yellow-fronted Canary was plentiful on both the east and west sides of Ruwenzori up to an elevation of $7000 \mathrm{ft}$. It was also seen at Fort Beni.- R. B. W.

Emberiza flaviventris Steph. (Plate XIX. figs. 1 \& 5, eggrs.)

Emberiza flaviventris Shelley, 13. Afr. iii. p. 143 (1902); Reich. Vüg. Afr. iii. p. 281 (1904).

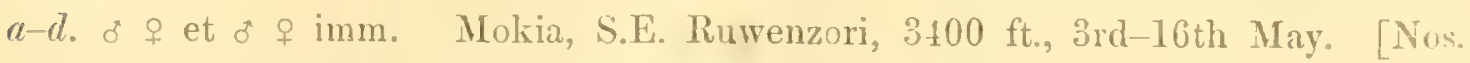
293.R. H. D.; 1537.D.C.; 2321.G.L.; 3364.R. B.W.]

e-g. of ㅇ. Mokia, S.E. Ruwenzori, $3400 \mathrm{ft}$, 3rd-17th June. [Nos. 447. R. E. D.: 1655. D. C.; 3450. R. B. $[\mathrm{W}$.

Adult male and female. Iris dark brown; bill brown or blackish, lower mandibie paler; feet brown or light brown.

The male from S.E. Ruwenzori (No. 1635), killed on the 17th of June, is moulting 
and in rather an interesting stage of plumage, the mantle being nearly uniform light red; but among the worn plumage several new feathers of a darker chestnut colour margined on the sides with sandy-buff are making their appearance.

A young female (No. 2321) has the feathers of the mantle very distinctly streaked with black, more so than in the adult female; the feathers of the chest have dark brown shaft-streaks, and the white tips of the median wing-coverts are bisected by back shaft-streaks.

'This species is readily distinguished from the allied $E$. poliopleura (Salvad.) by having the feathers of the back uniform grey, while in the latter they have very distinct biack middles.

'The eggs of this species figured on the accompanying I'late form part of Mr. F.J. Jackson's collection.

[The Common Golden-breasted Bunting was met with only at the south end of Ruwenzori among the acacia-trees. $-R . B . W$.

\section{Family A L A U D D S E.}

\section{Mirafra zomber Grant.}

Mirafra zombe Grant, 13ull. B. O. C. xiii. p. 27 (1902).

Mirafia fischeri Shelley, B. Afr. iii. p. 43 (1902) [part.]; Reich. Vög. Afr. iii. p. 339 (1904) [part.].

a-e. o 오. Mokia, S.E. Ruwenzori, $3400 \mathrm{ft} ., 25$ th-29th April. [Nos. 237, r.

262.R.E.D.; 1434, 1443. D.C.; 2293. G. L.]

f-s. o o et o imm. Mokia, S.E. Ruwenzori, $3400 \mathrm{ft} ., 3 \mathrm{rd}-26 \mathrm{th}$ May. Nos. $296,315,332,376 . R$. E. D. ; 1513. D. C. ; 2324, 2346, 2352, 23533,2360 , 1.

$2351,2394 . G . L \cdot ; 3354 . R . B . W$.

t, u. q. Mokia, S.E. Ruwenzori, 13th \& 16th June. [No. 3473, 3487.R.B.W.]

Adult male and female. Iris brown or dark hazel; bill brown or black, lighter on the lower mandible; feet brown or flesh-colour.

This dark mountain-form allied to $M$. fischeri was originally described from specimens procured by Mr. A. Whyte on the plains of Zomba, and on the lower slopes of the Milanji Plateau at an elevation of $3000 \mathrm{ft}$. It is very interesting to find what is apparently exactly the same dark form occurring on the plains to the south-east of Ruwenzori at a similar elevation. Dr. Reichenow, who has apparently never examined specimens of $\boldsymbol{M}$. zombre, has united it with $M$. fischeri; but there can be no doubt that it is a very distinct and easily recognized form, which takes the place of $M$. fischeri on the higher ground over at least a part of the range of the latter species. 
[This little Lark was very numerous in the acacia-country on the plains around the south end of Ruwenzori, but was not seen on the mountains above an elevation of $4000 \mathrm{ft}$. While hovering in the air it makes a curious drumming noise with its wings. $-R . B . W$.

\section{Mirafra tropicalis Hartert.}

Mirafra africana tropicalis Hartert, Nov. Zool. vii. p. 45 (1900) [Lake Districts and Uganda]; id. Bull. B. O. C. xix. p. 92 (1907).

Mirafra africana Shelley, B. Afr. iii. p. 51 (1902) [part.].

$a-c$. o. Mokia, S.E. Ruwenzori, $3400 \mathrm{ft}$, 25th-29th April. [Nos. 240. R. E. D. ; 1433, 1457. D.C.]

d-k. $\delta^{\pi}$. Mokia, S.E. Ruwenzori, $3400 \mathrm{ft.g} 5$ th-24th May. [Nos. 331. R. E. D. ; 2335, 2341, 2342, 2343, 2351, 2392. G. L.]

l. $m$. o ㅇ. Mokia, S.E. Ruwenzori, $3400 \mathrm{ft}$., 4th June. [Nos.424, 425. R. E. D.]

Alult male and female. Iris hazel; bill dusky horn-colour or brown, whitish on the lower mandible; feet brown or light brown.

I have compared the above-mentioned series of specimens with the type of $M$. tropicalis Hartert, from Bukoba on the west coast of Lake Victoria; they agree perfectly with one another and evidently represent a well-marked subspecies. Dr. Hartert has already pointed out that Captain Shelley was mistaken in supposing that $M$. occidentalis (Hartl.) from Gaboon is synonymous with $M$. tropicalis, and has shown that the former is in reality more nearly allied to the South African form M. africanc [cf. Bull. B. O. C. xix. pp. 93 \& 94 (1907)].

[Hartert's Rufous-naped Lark was plentiful on the plains around the south end of Ruwenzori, but was not found on the mountains. It frequents the acacia-country. and is constantly to be seen perched on the top of some low bush uttering from time to time a long singie note. $-R . B . I Y$.]

\section{Family MOTACILLIDE.}

Motacilila vidua Sundev.

Motacilla vidua Shelley, B. Afr. ii. p. 268, pl. xii. fig. 1 (1900); Reich. Vög. Afr. iii. p. (1904).

a. 8. 40 miles W. of Entebbe, $3500 \mathrm{ft}$, 27 th Nov. [No. 2008. G. L.]

b. ․ Mubuku Valley, E. Ruwenzori, $7000 \mathrm{ft}$, 3rd Jan. [No. 3064. R. B. II

Adult male and female. Iris dark brown; bill and feet black.

[The African Pied Wagtail was met with throughout the journey, and occurred on Rurvenzori up to an elevation of $7000 \mathrm{ft}$. It was an extraordinarily tame and familiat bird, secming to prefer the vicinity of habitations. At each base-camp formed by the 
lixpedition, a pair of these Wagtails built a nest in the roof of our house, almost as roon as it was finisher.- $-R . B . W$.

\section{Motacilla longicadia Rüpp.}

Motacilla longicauda Shelley, B. Afr. ii. p. 274 (1900); Reich. Vüg. Afr. iii. p. 301 (190 s).

a, b. o $q$ ? vix ad. Mpanga Forest, Fort Portal, 5000 ft., 18th Sept. [Nos. 535, 535 a. R. E. D.]

Iris brown; bill black; feet slate-colour.

Neither of these specimens appear to be fully adult. In the male the third pair of tail-feathers have the greater part of the outer web and a broad band down the margin of the inner web black; the fourth pair have a black line down the middle third of the outer web, and the two outermost pairs are pure white. In the female (which has the tail-feathers in mouit) the third pair have the outer web mostly black, but no black on the inner web, the fourth pair have a black line down the middle third of the outer web as in the male, and the two outermost pairs are pure white; moreover, the second pair of normally black tail-feathers (which are worn and apparently remains of the first plumage) are irregularly marked with white towards the tip.

[A pair of the Long-tailed Pied Wagtail were obtained in the Mpanga Forest, and a pair of Wagtails believed to be of the same species were seen on a stream in the Congo Forest. When flying up or down the streams in the forest they always kept close to the water, and their flight was straight and swift, more like that of a Kingfisher than a Wagtail.- $R . B . W$.

\section{Motacilla Flava Linn.}

Motacilla Aava Shelley, B. Afr. ii. p. 286 (1900).

Budytes Aara Reich. Vög. Afr. iii. p. 303 (1904).

a. d. 40 miles TW. of Entebbe, $3500 \mathrm{ft}, 27$ th Nov. [No. 3011. R. B. W.]

b. c. $q$ imm. So miles W. of Eutebbe, 3500 ft., 2nd Dec. [Nos. 2014, 2015. G. L.]

1. o imm. 100 miles W. of Entebue, 4100 ft., fith Dec. [No. 1040. D. C.]

$e-g$. o 9 imm. 120 miles W. of Entebbe, $4000 \mathrm{ft}$., Tth \& 8th Dec. [Nos. 3t, 35. R. E. D. ; 2024. G. L..]

h. o. Mubuku Valley, E. Ruwenzori, $6000 \mathrm{ft.,2}$ th Dec. [No. 53. R. E. D.]

i. o imm. Mubuku Valley, E. Ruwenzori, $6000 \mathrm{ft}$., 1st Jan. [No.62.R.E. D.]

Adult male. Iris dark brown; bill dark brown; feet black or dark grey.

Some of the specimens have a good deal of olive-colour in the middle of the gres crown, and in that respect approach $H_{\text {. }}$ campestris Pall.

[A good many examples of the Common Yellow Wagtail were seen between 
Fntebbe and Ruwenzori and occasionally met with on the mountains up to an elevation of 6500 feet. $-R . B . W$.]

\section{ANThus pYRRHonotes (Vieill.).}

Anthus pyrrhonotus Shelley, B. Afr. ii. 1. 307 (1900).

Anthus lencophrys sordidus Reich. Vög. Afr. iii. p. 318 (1904.).

a, b. o. 60 miles W. of Entebbe, $3700 \mathrm{ft.}$, 29th Nor. [Nos. 15, 16. R. E. I).]

c, d. o ㅇ. Nokia, S.E. Ruwenzori, $3400 \mathrm{ft}, 4$ th \& 8th May. [Nos. 300. R. E. I); 2329. G. L.]

$e-i$. $\delta^{*}$ o et o imm. Mokia, S.E. Ruwenzori, $3400 \mathrm{ft}, 3 \mathrm{~d}$-17th June. [Nos. 417. R. E. ID. ; 2398, ㄴ406. G. L. ; 3479, 3480. R. B.W.]

k. \&. 60 miles N. of Fort Beni, Semliki Valiey, $3500 \mathrm{ft}$, 17th Aug. [No. 17.91. II.C.]

Adult male and female. Iris dark brown; bill brown or blackish, lower mandibie yellowish; feet flesh-colour or brown.

All these birds appear to be typical examples of $A$. pyrrhonotus (Vicill.). I am unable to distinguish the subspecies $A$. gouldi Fraser, the length of the hind claw being in my opinion too variable a character to place much reliance on. For instance, among the present series some specimens have the hind toe equal in length to the hind claw, while in others it is much shorter.

['This Pipit was met with near Entebbe and on the plains round Ruwenzori, but it did not ascend the mountains. It has a habit of suddenly flying up perpendicularly into the air to a height of 20 or 30 feet and then dropping head first, with closed wings, almost to the ground, only opening its wings just before alighting. I have noticed it doing this repeatedly, for half an hour at a time, generally in the evening, over some open patch of ground where it could run about freely in search of insects.R. B. W.]

\section{Anthus trivialis Linn.}

Anthus trivialis Shelley, B. Afr. ii.p. 299 (1900); Reich. Vög. Afr. iii. p. 311 (1904); Jackson, Ibis, 1906, p. 559 [Toro].

a. o. 120 miles W. of Entebbe, $4200 \mathrm{ft}$., 8th Dec. [No. 1045. D. C.]

b. Adult. Mubuku Valley, E. Ruwenzori, $6000 \mathrm{ft}, 29$ th Dec. [No. 54. R. E. D.]

$c-f$. $o^{\circ}$. Mubuku Valley, E. Ruweuzori, $6000-7000 \mathrm{ft} ., 1 \mathrm{st}-2$ th Jan. [Nos. 61. R. E. D. ; 2065, 2071, 211\%.G.L.]

g, h. o. Mubuku Valley, E. Ruwenzori, $6000 \mathrm{ft}$., 18th \& 21st March. [Nos. 1372. D.C.;2226. G. L.]

Adult. Iris hazel or dark brown; bill brown or blackish, lower mandible light brown; feet light brown, brown, or flesh-colour.

YoL. XIX.-PAIT IV. No. 42.-March, 1910. 
[The Tree-Pipit was seen on Ruwenzori as late as the 18th of March, and was met with up to an eleration of $7000 \mathrm{ft}$. It was seen near Entebbe in December. - IR. B. II.]

Axtiles Leggei Grant. (Plate XIII. fig. 4, त.)

Anthus leggei Grant, Bull. B. O. C. xix. p. 26 (1906).

a, b. o q. Mokia, S.E. Ruwenzori, $3400 \mathrm{ft}$, 7th \& 24th May. [Nos. 2314, 2391. G. L. Types of the species.]

c, d. o*. Mokia, S.E. Ruwenzori, $3400 \mathrm{ft} ., 22 \mathrm{nd} \& 23 \mathrm{rd}$ Nay. [Nos. 3396 , 3404.R.B.W.]

e, f. $\delta$. Mokin, S.E. Ruwenzori, $3400 \mathrm{ft} ., 6$ th \& 17 th June. [Nos. 432. R. E. D.; 1631. D. C.]

'This species is most nearly allied to A. brachyurus Sundev., from which it differs chiefly in its somewhat smaller size, the white ground-colour of the underparts, and the very strong black markings on the chest and breast. Iris dark brown; upper mandible hlack, lower mandible brown; feet brown, pale brown, or pale flesh-colour.

8. Total length ca. 4.5 inches; wing 2.5 ; tail 1.55 ; tarsus 0.64 .

ㅇ. , " $, 4.5, \quad, 2 \cdot 45-2 \cdot 5$; tail $1.35-1 \cdot 5$; tarsus 0.64 .

[This very small Pipit was found only on the plains round the south end of Ruwenzori, and did not ascend the mountains. It was not a common bird and most difficult to procure, as it was impossible to see it while on the ground on account of the long grass. It was very reluctant to take flight, but, when once on the wing, flew with remarkable swiftness, usually rising to a considerable height and settling a long way off. $-R . B . H$.

Macrosyx croceus (Tieill.).

Macronyx croceus Shelley, 13. Afr. iii. p. 4 (1002); Rcich. Vïgr. Afr. iii. p. 321 (1901).

1. $\therefore$ Entebbe, $3500 \mathrm{ft}$, , 1Sth Nov, [No. 1002. D. C. $]$

b. o. 12 miles W. of Entebbe, $3500 \mathrm{ft}$., 24th Nov. [No. 3002. R. B. IV.]

c. $\delta .40$ miles W. of Entebbe, $3500 \mathrm{ft}, 27$ th Nov. [No. 10. R. E. D.]

1. f. 100 miles W. of Entebbe, $4100 \mathrm{ft}$., 4 th Dec. [No. 2017.G. L.]

e. o. Mokia, S.E. Ruwenzori, $3 \pm 00 \mathrm{ft.,} 24$ th April. [No. 233. R. E. D.]

$f^{\prime}-m .8$. Mokia, S.E. Ruwenzori, $3400 \mathrm{ft}$., 1st-29th May. [Nos. 265,338 , 390. R. E. D. ; 2313, 2336, 2337, 23ts. G. L.]

n. o. Mokia, S.E. Ruwenzori, $3400 \mathrm{ft}, 13 \mathrm{th}$ June. [No, 452. R. E. D.]

Adult male and female. Iris hazel to dark brown; upper mandible black, lower mandible bluish-horn colour; feet brown or light brown.

'There is a specimen of $\lambda I$. croceus in the Britisin Museum procured by Lord Delamere 
on the Athi River, B.E. Africa, which is in a remarkable stage of plumage and unlike that of any other specimen which I have examined. 'The sides and flanks are pale sandy, heavily streaked with black shaft-stripes, and the yellow on the underparts is restricted to the middle of the breast and belly. The bird is probably a female attaining its first adult plumage, many of the fenthers being only partly grown, but the light colour of the sides and flanks is peculiar, though probably only individual.

Through the kindness of Count Salvadori and of Mr. Walter Rothschild I have been able to compare the type-specimen of Macromyx ascensi Salvadori [cf. Bull. Mus. 'Tor. xxii. no. $570(1907)]$, from Lake Meru, with a typical specimen of IX. fiulleborni Reichenow, from Ngomingi, Uhehe Country (Marwitz), sent to the Tring Museum by Dr. Reichenow; also with two specimens of Macronyx procured in Angola respectively by Dr. W.J. Ansorge in July and by Mr. C. H. Pemberton in December. 'These latter agree exactly with the type of $M$. ascensi, and though they are slightly brighter yellow on the breast and greyer on the rump than the typical specimen of $M$. fulleborni, $I$ think it highly probable that all should be included moler the latter heading. 'The typical specimen of $M$. fulleborni, which was killed in the month of August, is in partly worn plumage, but the feathers of back and rump have been recently moulted, which may account for their browner colour.

[The Yellow-throated Jong-claw was plentiful from Entebbe to Ruwenzori and on the plains all round the mountains below $5000 \mathrm{ft} .-l i . B . W$.

\section{Family NeCTARIII}

\section{Nectárixia erttirocerca Heugl.}

Cinmyris erythrocerius Shelley, B. Afr. ii. p. 49 (1900).

Nectarinia erythrocerca Reich. Vüg. Afr. iii. p. 493 (1905); Jackson, Ibis, 1906, p. 550 [T'oro].

Nectarinia erythroceria Grant, Ibis, 1908, p. 282 [Lake Edward].

a, b. o 오. 60 miles W. of Entebbe, $3700 \mathrm{ft.}$, 29th Nov. [Nos. 3013, 3014. li. li. II.

$c-e . \delta^{*}$. Mokia, S.E. Ruwenzori, $3400 \mathrm{ft} ., 24$ th-2Sth June. [Nos. 1679, 1700, d.

1701. D.C.]

Adult male and female. Iris dark brown; bill and feet black.

As already recorded, in my paper on the "Birds collected in Uganda and the Upper" Congo," this species was procured by Mr. Carruthers a little to the north of Lake Edward, which is probably the most southerly and westerly point from which it has been obtained.

In the four males mentioned above the colour of the upper tail-coverts varies consiclerably. Nos. 3013 and 1700, from Entebbe and S.E. Ruwenzori respectively, have 
the upper tail-coverts mostly peacock-blue, while in Nos. 1679 and 1701, both from S.E. Ruwenzori, they are bright purple. 'This difference is no doubt caused by weathering. 'The under tail-coverts also vary greatly: in some specimens they are quite black, while in others they are widely tipped with purple.

[Heuglin's Wedge-tailed Sun-birl was seen between Entebbe and Ruwenzori, and at the foot, of the mountains on the east side. It was not an uncommon bird at the south-east end of the range, and it was also seen at fort Beni.-R. B.W.]

Nectaticia melavogastra Fischer \& Reichenow.

Nectarinia melanogastra Shelley, B. Afr. ii. p. 25, pl. i. fig. 2 (1900) ; Reich. Vög. Afr. iii. p. $496(190.5)$.

Nectarinia melunogaster Jackson, Ibis, 1906, p. 554 [Ruwenzori].

'There is an adult male of this species in Mr. Jackson's collection, which was procured by Mr. Geoffrey Archer on Ruwenzori on the 13th of February, 1902, but the exact locality is not recorded. 'The species was not met with by the members of the Expedition.

\section{Nectarixia cupreonitens Shelley.}

Nec'arinia cupreonitens Shelley, B. Afr. ii. p. 21 (1900).

Neciarinia Jamosa (Linn.); Reich. Vög. Afr. iii. p. 499 (190j) [part.].

a-c. ơ et o imm. Butagu Valley, W. Ruwenzori, 4000-5400 ft., 25 th July. [Nos. 1759, 1760. D. C.; 2437. G. L.]

Iris dark brown; bill and feet black.

After a careful examination of all the specimens of $N$. famosa (Linn.) and $N$. cupreonitens Shelley, both in the British Museum and in Mr. Jackson's collection, I fiud that the present form can be recognised by its shorter and more curved bill, ats well as by its slightly smaller size, from examples of $\mathrm{V}$. fimosa from South Africa, and should be kept separate.

According to Mr. A. Stark and Captain Shelley, birds of this genus after the breeding-season assume a change-plumage like that of the adult female. Agrainst this theory I may mention that among the large series of specimens of N. fumosa collected by Mr. Claude Grant in South Africa there are full-plumaged males procured throughout the whole year. All the evidence points to the fact that the birds which Captain Shelley and others supposed to be adult males in changeplumage are really younger males in an intermediate hen-like plumage, which is assumed after the first plumage and retained during the first year. 'The metallic wings and long middle tail-feathers, like those of the adult, are then assumed, but the head and rest of the upperparts as well as the breast remain much like those of the female, but are intermixed with a few scattered metallic feathers. Subsequently the metallic back and breast of the fully adult male are acquired. There are numerous immature males 
in the British Museum collection in which the metallic feathers of the back are obviously moulting, many being only partially grown, but there is not a single specimen with the metallic back which is assuming the olive-brown plumage, and if this intermediate plumage was really an eclipse plumage such specimens wonld certainly be found among the large series I have examined. I therefore assume that males of the genus Nectarinia, unlike the males of Cimnris, do not assume the fully adult plumage during the first year, and that during that period they are clad in an intermediate and partly hen-like plumage.

[A few examples of the Northern Malachite Sun-bird were met with just at the foot of the mountains on the west side of Ruwenzori, near the mouth of the Butagu River. They were not uncommon at this spot, but were never met with again throughout the whole journey.-R. $B . \mathrm{H}^{\mathrm{r}}$.]

Nectarinia Kilimensis Shelley. (Plate XIX. fig. 9, egg.)

Nectarinia kilimensis Shelley, B. Afr. ii. p. 28, pl. i. fig. 1 (1900); Reich. Vüg. Afr. iii. p. 50:2 (1905); Jackson, lbis, 1906, p. 555 L'T'oro].

a-e. o . 90 to 120 miles W. of Entebbe, $4000 \mathrm{ft}$, 4th-9th Dec. [Nos. 43. R. E. D.; i.

1031, 1043. D.C.; 3027, 3047.R.B.W.]

f-i. of $q$ et $\delta^{*} \mathrm{imm}$. Mubuku Valley, E. Ruwenzori, $6000 \mathrm{ft}$., 28th-31st Dec. d.

[Nos. 1067. D. C.; 2032, 2035, 2042. G. L.]

k-0. o $q$. Mubuku Talley, E. Ruwenzori, $6000 \mathrm{ft}$, ] st-2th Jan. [Nos. T⿸. R. E. D. ; 1080. D. C. ; 2007,2112 . G. L.; 3071. R. B. W.]

p. o imm. Mubuku Valley, E. liuwenzori, $7000 \mathrm{ft} ., 25$ th Feb. [No. 175. R. E. D.]

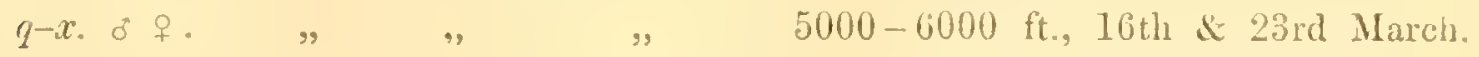

[Nos. 206, 210, 221. R. E. D.; 1363, 1364. D. C.; 2205, 2207, 2209. G. L.]

\%. o imm. Mubuku Valley, E. Ruwenzori, $5000 \mathrm{ft.}, 7$ th April. [No. 2281. G. L.]

z. +. Fort Beni, Semliki Valley, 3000 ft., 24th July. [No. 2433. G. L.]

Alult male and female. Iris dark hazel or dark brown; bill and feet black.

I am rather doubtful if specimen 2133 is really a female of $N$. Kitimensis, for it has the general colour of the underparts brownish-yellow. It, howerer, closely resembles a female from Toro in the Jackson Collection, which latter has the underparts intermediate in colour between typical yellow-breasted $N$. Kilimensis and the brownerbreasted bird from Fort Beni.

'The egrg figured on the accompanying Plate forms part of Mr. F. J. Jackson's collection, and was procured on the Mau Downs on the 18th of December, 1395.

[The Kilimanjaro Bronze Sun-bird was met with almost everywhere throughout the 
journey wherever the tree Erythrina tomentosa grows. We met with it on Ruwenzori up to an elevation of $7000 \mathrm{ft}$, but it was not found in the dry acacia-country around the south end of the range, where this tree is very scarce. All the Sun-birds, but more especially those with long bills, which enable them to probe the deep cup of the flower of $E$. tomentosa, are greatly attracted by its clusters of scarlet blossom. N. kilimonsis appears to feed on it almost exclusively, and, so far as our experience went, the species is not found where this tree does not occur.- $R . B . W$. ]

Nectarinia dartuoctui Grant. (Plate XII. figs. 1, o* ; 2, ㅇ.)

Nectarinia dartmouthi Grant, Bull. 13. O. C. xvi. p. 117 (1906).

a-p. of $q$ et of $q \mathrm{imm}$. Mubuku Valley, E. Ruwenzori, 12,000-13,000 ft., 29th \& 30th Jan. [Nos. 1191, 1192, 1193, 1194, 1195, 1196, 1197, 119S, 1199, 1201. D. C. ; $\left.3133^{*}, 3134,3135,3136,3137 . R . R . T \%.\right]$

$q-w$. of ot ot imm. Mubuku Valley, E. Ruwenzori, 12,500-13,000 ft., 15th \& 19th Feb. [Nos. 155, 156, 161* * R. E. D.; $3166,3167,3168,3169 . R . R . W$.

$x-a^{\prime}$. o . Mubuki Valley, E. Ruwenzori, 13,000-14,500 ft., 3rd \& 5th April. [Nos. 230, 230 a. R. E.D.; 1425, 1426. D. C. ]

The male of this splendid alpine species is most nearly allied to that of $\boldsymbol{N}$. salvalorii Shelley, having the same rather short and but slightly curved bill, but is easily distinguished by having the upperparts of a rather darker green, shading into dark greenishblue on the rump. 'The upper tail-coverts, margins of the tail-feathers, belly, sides, and flauks are of the same greenish-blue tint. Iris dark hazel; bill and feet black. 'Total length about 10.4 inches; culmen 1.1 ; wing 3.2 ; middle tail-feathers 6.5 , lateral tail-feathers $2 \cdot 3$; tarsus $0 \cdot 8$.

'The female is very similar to that of $\lambda$. johnstoni Shelley, but is easily distinguished by the shorter and straighter bill.

The occurrence of this remarkably handsome Sun-bird dwelling on the highest parts of the range, close to the limit of vegetation, was perhaps the most important discovery made by the Expedition. It has been named in honour of the Earl of Dartmouth, who was one of the principal subscribers to the Ruwenzori Expedition. His son, Mr. Gerald Legge, was one of the most successful collectors who took part in this memorable exploration.

['This beautiful Sun-bird was found only on Ruwenzori, where it frequented the lobelia- and groundsel-zone from an elevation of 12,500 ft. up to 14,500 ft. In the early morning, when the sun generally shines upon the higher parts of the range for a few hours before the cloud-bank has accumulated, these regions scem alive with the males

* Types of the spocies. 
of this beautiful green Sun-bird and their more sombrely clad wives. Their short cheerful song is heard on all sides, uttered from the top of a tall lobelia-spike or bunch of giant groundsel. It is a very pretty sight to see them feeding upon the lobelias, as they cling to the side of the tall flower-spike. With their legs held horizontally so as to keep the body away from the flowers, they swiftly probe the long pale blue tubes of the blossom with their curred beaks. The males are incessantly fighting with one another or flirting with the females, and each pair seems to claim a certain district as its own, from which all trespassers are hastily and noisily chased. They show little or no fear of man, and one actually settled upon the barrel of Mr. Carruthers's gun while he was standing still. Where found they are extremely plentiful, but as they are never met with below 12,500 ft. they do not occur among the tree-heaths, and apparently feed entirely upon the lobelia-blossoms.

In dark misty weather few of these birds were to be seen, but their song was often heard in spite of mist and rain. They were breeding in January, which is the driest month of the year, and some of the young were already fledged. Unfortunately, we failed to find a nest. $-R . B . H^{5}$.]

\section{Nectarisia purpureitentris (Reichenow).}

Cinnyris purpureiventris Sheller, B. Afr. ii. p. 39 (1900).

Nectarinia barake Sharpe, Bull. B. O. C. xiii. p. 8 (1902), p. 50 (1903) [Ruwenzori].

Nectarinia purpureiventris Reich. Vör. Afr. iii. p. 503 (1905) [Migere, Mufumbiro]; Jackson, Ibis, 1906, p. 555 [Ruwenzori].

a. o imm. Mubuku Valley, E. Ruwenzori, $7000 \mathrm{ft}$, 10th March. [No. 2179. G. L.

Iris dark brown; bill and feet black.

The only example of this remarkably handsome Sun-bird procured by the Expedition is a male assuming the metallic breeding-plumage.

In the Jackson Collection there are numerous examples from Ruwenzori, procured by Mr. G. Archer, and, among them, males in full breeding-plumage shot in February and October. There is also a male, killed on the 13 th of February, assuming the metallic plumage, and rery similar to the bird in the present Collection, which was procured on the 10th of March. This would seem to indicate that the metallic plumage is assumed in February and March; but I have satisfied myself that both these specimens are immature birds assuming their metallic dress and not adult birds coming out of an "eclipse" plumage. This species was first procured by Stuhlmann at Migere, on the Mufumbiro Volcanoes.

[A single specimen of Baraka's Sun-bird was shot by Mr. Gerald Legrge in the Mubuku Valley, on the east side of Ruwenzori, at an altitude of $7000 \mathrm{ft}$. 'This was the only occasion on which the species was met with during the whole expedition around the mountains. It is a remarkable fact that Mr. Geoffrey Archer should have 
obtained nearly a dozen examples of this species on Ruwenzori, either in the Mubuku or Luimi Valleys, both of which were visited by the Lxpedition.- $R . B . W$.

\section{Anthothreptes axiluaris Reichenow.}

Anthothreptes axillaris Shelley, B. Afr. ii. p. 143 (1900).

Anthreptes axillaris Reich. Vög. Afr. iii. p. 442 (1905).

a. 8. 20 miles N.WV. of Fort Beni, Semliki Valley, $3000 \mathrm{ft}$, 11th Aug. [Nก. 505. R. E. D.]

b. ㅇ [? o imm.]. Irumu, Eturi Forest, $3000 \mathrm{ft} ., 16$ th Oct. $\quad[$ No. 555. R. E. D.]

Adult male. Iris dark brown; bill dusky; feet olire-brown.

Immature male? Iris hazel; upper mandible black, lower light horn-colour; feet sinte-colour.

This very distinct species is new to the British Museum. Specimen " $b$," marked "q" by Mr. Dent, is probably an immature male; for the female is said to have no pectoral tufts, while in the present specimen the tufts are distinctly indicated by a few yellow feathers tipped with orange. The bill, too, is much shorter than in the ardult male.

[A few of these little Grey-crowned Sun-birds were met with in the Eturi Forest between Fort Beni and Irumu. 'They appeared to frequent the undergrowth and not the tree-tops, but so few were seen that re could not be certain on this point. It is, however, an interesting one, for birds were very rarely found to inhabit both the undergrowth and the tree-tops. $-R, B . W$.]

\section{Axtrothineptes zambestaxa Shelley.}

Anthothreptes hypodila Shelley, B. Afr. ii. p. 151 (1000) [part.].

Anthreptes lypodila Reich. Vög. Afr. iii. p. 41.2 (1905) [part.].

Anthothreptes zambesiana Grant, Ibis, 1908, p. 286 [S.W. Uganda].

a. o. Mubuku Valley, E. Ruwenzori, $7000 \mathrm{ft}, 27$ th Jan. [No. 2116. G. I.]

b. ठ". " " $6500 \mathrm{ft}$, Gth Feb. [No. 1219. D. C.

$c$, d. o et ơ imm. Mubuku Valley, E. Ruwenzori, $7000 \mathrm{ft}$, 24th March. [Nos. 3257, 3258. R. B. W.]

e. o*. Mokia, S.E. Ruwenzori, $3400 \mathrm{ft}$, 6th May. [No. 1506. D. C.]

f. ๙. Fort Beni, Semliki Valley, $3000 \mathrm{ft.}, 22 \mathrm{nd} J u l y . \quad[$ [No. 1737. U.C.]

g. ㅇ. Mawambi, Congo Forest, $3000 \mathrm{ft}$, 29th Oct. [No. 3646. R. B. II.]

h. imm. Mpanga Forest, Fort Portal, $5000 \mathrm{ft}$., 21st Sept. [No. 553. R. E. D.]

Adult male and female. Iris dark brown; bill and feet black.

I have already cxplained my reasons for keeping $A$. zambesiane distinct from A. hypodila (Jard.) in my paper on Mr. Carruthers's collection published in 'The Ibis,' vide suprà. 
[A few examples of the Zambesi Collared Sun-bird were met with in the Eturi and Congo Forests and in the Mpanga Forest to the east of Ruwenzori, as well as on the mountains up to $7000 \mathrm{ft}$.; but they were distinctly scarce. A nest of this species was found on Ruwenzori at $7000 \mathrm{ft}$. ; it was placed among the leaves of a giant lobelia (Lobelice giberroce), about 8 fect from the ground, and was composed of very fine grass and the thin tendrils of creepers. Unfortunately the nest was forsaken when only half built. $-R . B . W$.]

Antiotireptes tephrol ema (Jard. \& Fraser).

Anthothreptes tephrolcma Slielley, B. Afr. ii. p. 156 (1900).

Anthreptes tephrolema licich. Vög. Afr. iii. p. 445 (1905).

"l-c. o + 10-40 miles N.WV. of Fort Beni, Semliki Valley, 3000-3500 ft., 10th13 th Aug. [Nos. 503, 507.R. E. D.; 1781. D.C.]

Adult male and female. Iris reddish-brown or dark brown; bill and feet black.

The female No. 507 is marked by Mr. Dent as "breeding; shot in clearing in forest."

[The Grey-chinned Collared Sun-bird was obtained only in the Eturi Forest, near Fort Beni, where it appeared to be a rare birl.- $R . B . W$.

\section{Cyanomitra ragazzil Salvad.}

Cyanomitra obscura Shelley, B. Afr. ii. p. 125 (1900) [part.].

Chalcomitra obscura Reich. Vög. Afr. iii. p. 450 (1905) [part, nec Fermando Po].

Chalconitra obscura ragazzii Reich. Vög. Afr. iii. p. 451 (1905).

1. o. Fort Beni, Semliki Valley, $3000 \mathrm{ft} ., 23 \mathrm{rd}$ July. [No. 3514. R. B.W.

b. 8. 30 miles N. of Fort Beni, $3900 \mathrm{ft.}, 12$ th Aug. [No. 1779. D. C.]

c-e. of $q$. Mpanga Forest, Fort Portal, $5000 \mathrm{ft}$. , 17th \& 21st Sept. [Nos. 526, R. E. D. ; 3600, 3601. R. B. W.]

Adult male and female. Iris brown or dark brown; bill and feet dark brown or black.

According to Dr. Reichenow, the birds from the M.lpanga Forest should be called C. ragazzii (Salvad.); but the differences between them and the birds from West Africa are too slight to warrant any separation. With this conclusion Captain Shelley fully agrees,

Birds from Fernando Po are slightly larger, and have the underparts greenishwhite: in birds from the mainland of Africa these parts are generally olive.

The type of Nectarinia obscura Jardine was procured in Fernando Po, and therefore the name $C$. ragazzii must be retained for the specimens from the African Continent. The British Museum possesses a typical specimen of C. ragazzii (Salvad.) from "Foresta di Fekerie-ghem," Shoa, killed on the 6th of May, 1885, and received FOL. XIX.-PART IV. No. 43.-March, 1910. 
in exchange from the 'Turin Museum. It is apparently not quite fully adult and still possesses traces of yellow on the throat and underparts, characteristic of immaturity. It is the specimen $b$ (155) [ $c f$. Salvad. An. Mus. Civ. Genov. xxvi. p. 247 (1888)], and is marked as "ㅇ," but is certainly a male with the yellow pectoral tufts well developed.

[This curious Sun-bird was plentiful both in the Eturi Forest and in the Mpanga Forest to the east of Ruwenzori. It was never seen except when darting hither and thither among the undergrowth with a surprisingly swift and jerky flight, uttering, as it flew, a short sharp note.-R. $B . W$.]

\section{Crayomitra cyanolæima (Jard.).}

Chalcomitra cyanolcema Reich. Vög. Afr. iii. p. 456 (1905).

a. ㅇ. 10 miles N.W. of Fort Beni, Semliki Valley, $3000 \mathrm{ft} ., 10 t h$ Aug. [No. 3538. R. B.W.]

b. ㅇ. Avakubi, Eturi Forest, $2500 \mathrm{ft.}, 31$ st Oct. [No. 581.R. E. D.]

Adult female. Iris dark brown; bill and feet black.

[The above-mentioned female examples of the Blue-throated Brown Sun-bird, obtained in the Eturi Forest, were the only ones seen. $-R . B . W$. $]$

Cinnyris vimidisplendens Reichenuw.

Cyanomitra verticalis Shelley, 13. Afr. ii. p. 127 (1900) [part.].

Chalcomitra verticalis viridisplendens Reich, Vög. Afr. iii. p. 454 (1905).

a, 万. $\delta$ ㅇ. 120-140 miles west of Entebbe, 4000-4500 ft., 9th \& 11 th Jec. [Nos. 46.R.E. D.; 3046.R.B.W.]

$c, d$. $\sigma^{*}$. Mubuku Valley, E. Ruwenzori, $6000 \mathrm{ft} ., 2$ Sth-29th Dec. [Nos. 1066 , 1069. D.C.]

$e-i$. o ㅇ. Mubuku Valley, E. Ruwenzori, $6000 \mathrm{ft}$., 1st-20̃th Jan. [Nos. 109, 114, 127. R. E. D. ; 1081. D.C.; 2072. G. L.]

k, l. o . . Mukubu Valley, E. Ruwenzori, $5000 \mathrm{ft}$., 22nd \& 2Sth March. [Nos. 226. R. E. D. ; 1401. D. C.

m-0. of. Mukubu Valley, E. Ruwenzori, $5000 \mathrm{ft}, 3 \mathrm{rd}$ \& 5 th April. [Nos.2267, $2268,2277$. G. L. $]$

$p, q . \sigma^{*}$ Mokia, S.E. Ruwenzori, $3400 \mathrm{ft} ., 5$ th \& 24th May. [Nos. 1615. D. C.;

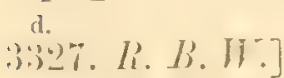

$r-v . \delta$ o. Mokia, S.E. Ruwenzori, $3400 \mathrm{ft}, 27$ th-29th June. [Nos. 1696, 1697 , 1708, 1709, 1710. D.C.]

w. o. Butagu Valley, W. Ruwenzori, $4500 \mathrm{ft} ., 28$ th July. [No. 49S. R. E. IJ.]

Iris dark brown; bill and feet black. 
All the male specimens in the present collection clearly belong to this rather larger, longer-billed, and greener-throated form of $C$. verticalis (Lath.). The West African birds have the bill somewhat shorter, and as a rule the throat is distinctly blue, though in a large series a few specimens which are intermediate as regards the colour of the chin and throat can be found. Moreover, the male of $C$. verticalis has the breast and underparts of a blackish-grey tint (in C. viridisplendens these parts are dark grey) and the female has the underparts of a soiled white tint, relatively much lighter than in C. viridisplendens, which is grey below and rather darker on the throat and chest.

Young males of $C$. viridisplendens in first plumage have the crown bright olive, with a few metallic-green feathers on the throat, the chest blackish mixed with some metallic-green plumes, and the rest of the underparts yellowish-olive.

Young fomales have the crown like that of the young males, but the throat and chest are yellowish-olive like the rest of the underparts.

[The eastern form of the Green-headed Olive Sun-bird was obtained near Entebbe, and was met with throughout the journey to Ruwenzori; it was not seen on the mountains above $7000 \mathrm{ft} .-R, B . W$.]

\section{Cinnyris AirN玉 (Jackson).}

Cyanomitra alina Jacks. Bull. B. O. C. xiv. p. 94 (1904); id. Ibis, 1906, p. 558 [Ruwenzori]. Chalcomitra alince Reich. Vög. Afr. iii. p. 841 (1905).

a-e. ot et imm. Mubuku Valley, E. Ruwenzori, 6000-9000 ft., 7th-23rd Jan. [Nos. 91.R.E. D.; 1118, 1163, 1181.D.C.; 3081. R. B. W.]

f- $q$. of $q$ et o imm. Mubuku Valley, E. Ruwenzori, 6500-9000 ft., 3rd-28th Feb. [Nos. 172, 173, 174. R. E. D. ; 1258, 1259, 1274. D. C. ; 2141, 2146, $2147,2148$. G. L. ; 3145. R. B. W.]

$r^{\prime} \imath^{\prime}$. of $q$ et o imm. Mubuku Valley, E. Ruwenzori, 5500-8000 ft., 4th-25 th March. $[$ Nos. 185, 200, 20S. R. E. D. ; 1294, 1310, 1340. D. C. ; 217S, $2180,2181$. 2182, 2183, 2192. G. L.; 3202, 3209, 3220, 3256, 3259, 3261. R. B. W.]

k. o. Mubuku Valley, E. Ruwenzori, $7000 \mathrm{ft.,} \mathrm{1st} \mathrm{April.} \mathrm{[No.} \mathrm{2263.} \mathrm{G.} \mathrm{L.]}$

l'. +. N. Ruwenzori, $7700 \mathrm{ft.,} 27$ th Sept. [No.559. R. E. D.]

Adult male and female. Iris crimson, reddish-brown, chestnut, or hazel; bill and feet black.

In the original description of the type-specimen the sex (male) is not stated, and no mention is made of the pale chrome-jellow pectoral tufts which are characteristic of that sex.

The female has never been described, but differs from the male only in lacking the pale yellow pectoral tufts. 
Young males have the crown, chin, and throat blackish, usually with a few metallic feathers, the mantle olive, without the orange wash found in the adult, and the breast and rest of the underparts greyish, washed with olive.

[Jackson's Purple-throated Sun-bird was found on Ruwenzori at elevations of from 5500 to $8500 \mathrm{ft}$. It was plentiful both in the forest and below it, feeding largely upon the scarlet flowers of Erythrina tomentosa. Females of this species were remarkably difficult to obtain; when numbers of these birds were feeding in the same tree the proportion of males to females was always as great as eight to one. This was the case during the whole time we remained in the mountains, so that the possible explanation that most of the females were engaged in incubation would not hold good.- R. B. W.]

Cinnyris aquatorialis Reichenow.

Chalcomitra requaturialis Reich. Vög. Afr. iii. p. 464 (1905); Jackson, Ibis, 1906, p. 55 z [T'oro].

a, b. đ. Entebbe, $3500 \mathrm{ft} ., 21$ st \& 26th Nov. [Nos. 1005. D. C.; 3005. R. B. W.]

c. 8. 100 miles W. of Entebbe, $4100 \mathrm{ft}$., Tth Dec. [No. 1042. D.C.]

$d-g$. of $q$ et i imm. Mubuku Valley, E. Ruwenzori, $5000 \mathrm{ft}$, 16th-26th March. [Nos. 223. R. E. D.; 1402. D. C.; 2204, 2250. G. L.]

h. of. Mokia, S.E. Ruwenzori, $3400 \mathrm{ft}, 28 \mathrm{th}$ April. [No. 1448. D. C.]

$i-y$. of o et o o imm. Mokia, S.E. Ruwenzori, $3400 \mathrm{ft}$, 4th-29th M[ay. Nos. 302, 307, 384, 393. R. E. D. ; 1603, 1604, 1616. D. C. ; 2327, 2328, 2338. G. L. ; 3318. d. d. d. d. $\left.3319,3326,34^{6} 2,3425,3426 . R . B . W.\right]$

$z, a^{\prime}$. o ㅇ․ Mokia, S.E. Ruwenzori, $3400 \mathrm{ft}$, 3rd \& 16th June. [Nos. 3446, 3490. R. B.W.]

b'. ㅇ. Mokia, S.E. Ruwenzori, $3400 \mathrm{ft}$., 6th July. [No. 1720. I. C.]

Adult male and female. Iris dark brown; bill and feet black.

All the above-mentioned specimens belong to the larger form of $C$. acik Antinori, which has been separated by Dr. Reichenow under the above name. The latter states that the metallic green of the top of the head and chin is of a different colour in the two forms; "but this does not appear to be really the case. 'The only real difference seems to be one of size, the more northern $C$. acik being altogether smaller and having a much shorter bill.

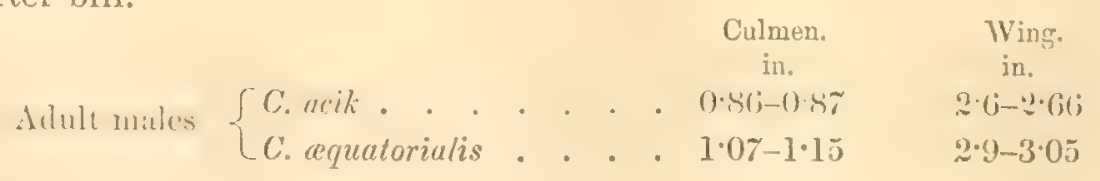

Mr. G. Archer notes that he did not meet with this species on Ruwenzori, though he procured specimens in 'Toro.

I'lue Larerer Scarlet-chested Sun-bird was seen throughout the journey from Entebbe 
to the edge of the Eturi Forest; but on Ruwenzori it did not ascend above $5000 \mathrm{ft}$. R. B. W.]

Cinntris falkensteini Fisch. \& Reichenow.

Cinnyris falkensteini Shelley, B. Afr. ii. p. 66, pl. iii. fig. 1 (1900) ; Grant, Ibis, 1908, p. 28? [N.W. of Lake Tanganyiki].

Cinnyris venustus falkensteini Reich. V̈̈g. Afr. iii. p. 474 (1905).

o . 100 miles W. of Entebbe, $4000 \mathrm{ft}$., 6th Dec. [Nos. 3032. R. B.W.]

This specimen was procured by Mr. Woosnam on the 6th of December, about 100 miles to the west of Entebbe, and on the following day he obtained typical examples of $C$. igneiventris, showing that the ranges of these two forms meet at this spot. 'The bird is a fully adult male, with the orange pectoral tufts and yellow belly and flanks characteristic of $C$. falkensteini.

\section{Cinnyris igneiventris Reichenow.}

Cinnyris venustus igneiventris Reich. Vög. Afr. iii. p. 475 (1905).

Cinnyris igneiventris Grant, Ibis, 1908, p. 282 (Lake Kivu).

$a-g$. o et of juv. 100-150 miles W. of Entebbe, 4th-12th Dec. [Nos. 103\%,

1047. D.C.; 2030. G. L. ; 3034, 3035̃, 3040.R. B. W.

h. ठ . Fort Portal, $5200 \mathrm{ft} .$, 5th July. [No. 3501. R. B.W.]

i-l. $\delta$ o . Mubuku Valley, E. Ruwenzori, $6000 \mathrm{ft}$., 3rd-6th Jan. [Nos. 64. R. E. I). ; 3066, 3147. R. B. W.]

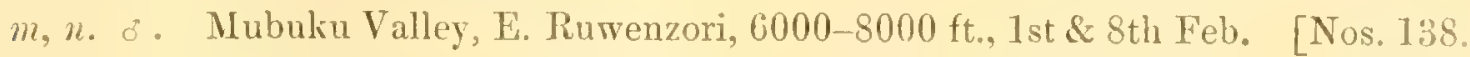
R. E. D.; 1221.D.C.]

o-q. of o imm. Mubuku Valley, E. Ruwenzori, 5000-7000 ft., 9th-13th March. [Nos. 2190, 2191. G. L. ; 3190. R. L. W.]

Adult male and female. Iris brown or dark brown; bill and feet black.

[The Fire-bellied Sun-bird was plentiful near Entebbe, and was not uncommon throughout the journey to Ruwenzori, where it was occasionally seen up to an elevation of $8000 \mathrm{ft}$. A few were also met with at the south end of the range, but they were rather rare there. $-R . B . W$.

\section{Cinnyris cupreus (Shaw). (Plate XIX. fig. 7 , egg.)}

Cinmyris cupreus Sheliey, B. Afr. ii. p. 36 (1900); Reich. Vög. Afr。 iii. p. 475 (1905); Jackson, Ibis, 1906, p. 556 [Entebbe].

a. o. 30 miles W. of Entebbe, $3500 \mathrm{ft} ., 26 \mathrm{th}$ Nov. [No. 3006. R. B. W.]

b. o imm. [? o ad.]. 150 miles W. of Entebbe, $4000 \mathrm{ft} ., 11$ th Dec. [No. 3053. R. B. $W$.

c, d. 3 imm. Nubuku Vallev, E. Ruwenzori, $5000 \mathrm{ft}$, 28th Feb. [Nos. 3183, 3184. R. B.W.] 
$\ell-k . \sigma^{2}$. Mokia, S.E. Ruwenzori, $3400 \mathrm{ft}$., 1st-28th Muy. [Nos. 389. R. E. D.; d.

1499, 1543. D.C.; 2311, 2316. G. L.; 3328. R. B.W.]

I, m. o f. Mokia, S.E. Ruwenzori, $3400 \mathrm{ft} ., 4$ th-16th June. [Nos. 3453, 3491. I. I. II.]

थ. o imm. Mokia, S.E. Ruwenzori, 3400 ft., 6th July. [No. 1721. D. C.]

Adult male and female. Iris dark brown; bill and feet black.

Specimen 3053 is marked as being a male, but has every appearance of being a female in worn plumage with some freshly moulted feathers on the back and chest.

'Tivo eggs taken by Mr. Woosnam (with the female specimen No. 3453) are of a rather blunt-pointed oval shape and devoid of gloss. The ground-colour is pale yellowish-white, obscurely clouded and smeared with grey, sparingly marked with rounded spots and short irregular streaks of brownish-black. They measure respectively $\cdot 68 \times \cdot 52$ and $\cdot 66 \times \cdot 5$ in.

An egg in the British Museum referred to this species and taken at Witu was received with the Crowley Bequest. It is much smaller than those collected by Mr. Woosnam and measures $\cdot 61 \times 41$ in., and is also differently marked. It, however, agrees with the description and measurements of eggs of $C$. cupreus given by Nehrkorn [cf. Kat. Eier Samml. p. $76(1899)]$.

[The Common Copper-coloured Sun-bird was seen near Entebbe and on the plains around the E. and S.W. of Ruwenzori, but it was not met with on the mountains. A nest found on the 5th of June was suspended from the bough of an acacia-tree about $5 \mathrm{ft}$. from the ground; it was composed of fine grass and the down of plants and contained two eggs. $-R . B . W$.]

Ciñuris superbus (Shaw).

Cinnyris superbus Shelley, B. Afr. ii.p. 41 (1900); Reich. Vög. Afr. iii. p. 477 (1905).

a-c. o f. Ft. Beni, Semliki Valley, $3000 \mathrm{ft} ., 21$ st July. [Nos. 484, 485. R. E. D. ; $3007 . R . B .[V]$

d. ot. Avakubi, E. Congo Forest, $2500 \mathrm{ft} ., 31$ st Oct. [No. 3652. R. B.W.]

Iris dark brown; bill and feet black.

[The Superb Sun-bird was not uncommon around Fort Beni on the eastern edge of the Eturi Forest, and was met with sparingly in the clearings in the forest between Fort Beni and Mawambi. It was not observed in the forest near Irumu.- $R . B . W$. .

CinNTRIS Mariquensis Smith.

Cinnyris mariquensis Shelley, B. Afr. ii. p. 51 (1900); Reich. Vög. Afr. iii. p. 479 (1905).

Cinnyris mariquensis suahelicus Reich. 1. c.

Cinnyris osiris Shelley, 1. c. 1. 53 [part.].

a. o. 100 miles W. of Entebbe, $4100 \mathrm{ft} . \quad$ [No. 1044. D.C] 
Iris dark hazel ; bill and feet black.

This bird, a nearly adult male, belongs to the typical South? African form, which it resembles in every particular, including the length of the bill. Cinnyris suchelicus Reichenow should be referred to the synonymy of $C$. mariquensis, and not to that of C. osiris as quoted by Captain Shelley [B. Afr. ii. p. 53 (1900)].

[The Southern Bifasciated Sun-bird was met with only between Entebbe and Ruwenzori.-R. B. W.]

\section{Crnnyis Microriyncuos Shelley.}

Cinnyris microrhynchus Shelley, B. Afr. ii. p. 55 (1900).

Cinnyris mariquensis microrhynchus heich. Vüg. Afr. iii. p. 481 (1905).

थ. ơ. Mokia, S.E. Ruwenzori, 3100 ft., 28th April. [No. 3290. R. B. W.]

$b f .0$ o ․, $, \quad, \quad 9$ th-31st May. [Nos.402.R. E. I); 1527, 1565, 1566. D. C.; 3405. R. B. W.]

g. o. Mokia, S.E. Ruwenzori, $3400 \mathrm{ft} ., 16$ th June. [No. 3496. R. IB. W.]

Adult male and female. Iris dark brown; bill and feet black.

'The six male examples from S.E. Ruwenzori included in the present collection are somewhat puzzling, and, though I think they must all belong to one species, they vary oue from another considerably in the colour of their plumage. First, as regards the colour of the under tail-coverts: in three specimens (Nos. 402, 1566, 3496) these parts are black with a dull purplish gloss; in one (No. 1565) they are brilliant metallic purplish-blue margined with bluish-green; while in the remaining two (Nos. 1527, 3290) they are intermediate in colour, being black tipped with greenish-blue. In the bird with the brilliant under tail-coverts the metallic purplish-blue bands across most of the feathers of the maroon-red breast-band are more strongly developed, and many of the feathers on the breast are tipped with purplish-blue. 'This is apparently an old male in the fullest plumage. One specimen (No. 1527) has the breast-band much brighter, some of the feathers being dull vermilion, and has the wing-measurement $2 \cdot 2$ inches and that of the tail $1 \cdot 4$. In the remaining five specimens the wing varies from 2.25 to $2 \cdot 4$ and the tail from 1.65 to $1 \cdot 75$, the difference in the length of the latter being considerable.

In Mr. Jackson's collection I find two specimens from Mount Maungu and the River Voi, both in the 'Teita district. One of these, from the Voi River, neariy resembles specimen No. 1527 from S.L. Ruwenzori in possessing a brighter breast-band and in having the measurements of the wing and tail equally small, $2 \cdot 1$ and $1 \cdot 4$ inches respectively; the second bird, from Mount Maungu, has the maroon breast-band washed with purple, the under tail-coverts black tipped with greenish-blue, the wingmeasurement $2 \cdot 25$ and that of the tail $1 \cdot 6$.

It must be added that the bird from the Voi River, killed in December, is in very 
worn plumage, while that from Mount Maungu, killed in April, is freshly moulted; but this difference could scarcely account for the difference in length of the tail, and it must be further noted that the short-tailed bird from S.E. Ruwenzori (No. 1527), killed in May, was procured with three long-tailed specimens shot in the same locality and during the same month. 'The matter requires further investigation.

[The Least Bifasciated Sun-bird was obtained only on the plains on the S.E. of Ruwenzori, where it was not uncommon.- $R . M . W$.

\section{Cinnyris bouvieri Shelley.}

Cinnyris bouvieri Shelley, B. Afr. ii. p. 57 (1900); Reich. Tög. Afr. iii. p. 483 (1905).

a. o. Mubuku Valley, E. Ruwenzori, $5000 \mathrm{ft}, 28$ th Feb. [No. 3185. R. B. $W$. $]$

Iris dark brown; bill and feet black.

'This bird closely resembles the type-specimen of $C$. bouvieri frum Landana, but is somewhat larger as regards the measurements of the wing and tail; while the bill is a trifle shorter, and very much shorter than in the type-specimen of $C$. tanganyica Grant, which I recently described from the western shores of Lake Tanganyika (cf. 'Ibis,' 1908, p. 283).

\begin{tabular}{|c|c|c|c|}
\hline Type of Cinnyris bouvieri. & & $\begin{array}{l}\text { Culmen. } \\
\text { in. } \\
0.9\end{array}$ & $\begin{array}{l}\text { Wing. } \\
\text { in. } \\
2 \cdot 1\end{array}$ \\
\hline Male from Eastern Ruwenzori . & & $0 \cdot 8$ & $2 \cdot 3$ \\
\hline Type of C.tanganyice & . & $1 \cdot 02$ & $2 \cdot 25$ \\
\hline
\end{tabular}

The Ruwenzori bird appears to have rather less blue on the forehead; but the pecimen is in worn plumage with much of the green metallic plumage of the upperparts and throat weathered to a pinkish-bronze colour.

The type of $C$. tanganyica is further distinguished from the other specimens mentioned above by its differently coloured orange-and-yellow (not scarlet-and-yellow) pectoral tufts.

The discovery of this West-African species on Ruwenzori greatly extends its known range.

[A few examples of Bouvier's Sun-bird were seen between Lntebbe and Ruwenzori and at the foot of the mountains on the east side to the north of the Mubuku Valley; but they were not found among the acacia-country around the south end, where C. microrhynchus, a very similar species, was so plentiful.-R. B. W.]

Cinnyris ciloropygius (Jardine).

Cinnyris chloropygius Shelley, B. Afr. ii. p. 83 (1900) [part.].

Cinnyris chloropygius lïhderi, p. 486, and C. c. orphogaster, p. 487, Reich. Vög. Afr. iii. (1905).

Cinnyris preussi Sharpe (nec Reich.), Ibis, 1908, p. 338 [Camaroon]. 
a. 8. 40 miles W. of Entebbe, $3500 \mathrm{ft}, 27$ th Nov. [No. 1013. D. C.]

b-g. $\delta$ ? . Fort Beni, Semliki Valley, $3000 \mathrm{ft.}, 20 \mathrm{th}-23 \mathrm{rd}$ July. [Nos. 1730, 1740, $1746,1748,1750$. D. C. ; 3506. R. B.W.]

Adult male and female. Iris dark brown or black; bill and feet black.

Dr. Reichenow recognizes three subspecies of this bird, viz. :-

1. Cimmris chloropygius (Jard.), ranging from Senegambia to the Niger.

2. C. c. liihderi Reichenow, ranging from Cameroon to Loango.

3. C. c. orphogaster Reichenow, ranging from the Upper Nile, above Lado, southwards to the Lakes.

With all the available material arranged geographically it is easy to recognize two forms, viz. that found in Sierra Leone, with its conspicuously olive underparts, and that inhabiting the Gold Coast, Niger, Cameroon, Fernando Po, and Gaboon, ranging southwards to Loango, and eastwards along the Congo to the Aruwimi and Welle Rivers, Tingasi, Semliki Valley, and Entebbe. I find it impossible to separate the west coast birds (C. c. liihderi Reich.) from the specimens procured in the neighbourhood of the Lakes (C.c. orphogaster Reich.); for though some individuals from Fantee, Cameroon, \&c. have the breast and belly of a more olive and less brownish tint, the bulk of the specimens are indistinguishable from one another.

The point which I wish to emphasize is that the type of $C$. chloropygius (Jard.) from the Niger River belongs to the darker-breasted form and not to the olive-breasted bird from Sierra Leone, as has been supposed by Dr. Reichenow and Dr. Hartert. The Sierra Leone bird is therefore, so far as I can discover, without a name, and I propose to call it

Cinnyris kempi, sp. n.

Cinnyris chloropygius Reich. (nec Jard.) Vög. Afr. iii. p. 486 (1905).

Adult male. Differs from $C$. chloropygius (Jard.) in being rather smaller, wing $1 \cdot 8$ to 1.9 inch, and in having the lower breast and belly, as well as the flauks and under tail-coverts, conspicuously olive.

There is a female example of $C$. chloropygius (No. 1748), procured by Mr. Carruthers in company with the adult male (No. 1746), which has the yellow chest and breast obscurely streaked with dusky, and in this respect differs from most of the female specimens in the British Museum which have been referred to C. chloropygius.

[A single specimen of the Little Scarlet-collared Sun-bird was obtained near Entebbe. It was not met with again until we reached Fort Beni in the Semliki Valley, where it was numerous. It was also seen in some of the clearings in the Eturi Forest between Fort Beni and Irumu.- $R . B . W$.

VOL. XIX.-PART IV. No. 44.-March, 1910. 
Cinnyris stuhumanni Reichenow.

Cinnyris stuhlmanni Shelley, B. Afr. ii. p. 80 (1900) ; Reich. Vög. Afr. iii. p. 488 (1905).

$a-d$. of ot et $\delta^{x} \mathrm{imm}$. Mubuku Valley, E. Ruwenzori, 10,000-11,000 ft., 27th31st.Jan. [Nos. 1203, 1204.D.C.; 3128, 3140. R. B.W.]

$e-h$. of et $\delta$ imm. Mubuku Valley, E. Ruwenzori, 9000-11,000 ft., 2nd-20th Feb. d. d. [Nos. 162, 162 A. R. E. D.; 1213, D. C.; 3164.R.B.W.]

i. o . Mubuku Valley, E. Ruwenzori, 11,000 ft., 5th April. [No.3267. R. B.W.]

Adult male and female. Iris dark brown; bill and feet black.

This remarkably interesting species was known only from male specimens procured by Stuhlmann. The exact locality where they were obtained was not indicated by the collector; but, from the information now at our disposal, it is practically certain that they were procured high up in the Butagu Valley on Western Ruwenzori.

Adult male. Perfectly similar in plumage to the male of $C$. reichenowi, but much larger. Culmen $1 \cdot 1-1 \cdot 15$ inch; wing $2 \cdot 55-2 \cdot 6$; tail $2 \cdot 25-2 \cdot 35$.

Adult female. Similar to the female C. reichenowi, but much larger. Culmen $1^{\circ} 0$ $1 \cdot 1$; wing $2 \cdot 35-2 \cdot 45$; tail $1 \cdot 7-1 \cdot 9$.

Specimen $162 \mathrm{~A}$, killed on the 20 th of February, is an immature male in partially adult plumage.

[Stuhlmann's Double-collared Sun-bird, which is known only from Ruwenzori, inhabits a belt little more than a thousand feet in width, and extending from about $10,000 \mathrm{ft}$. up to $11,200 \mathrm{ft}$. - that is, from the upper edge of the bamboo-zone to the lower half of the tree-heath. It is by no means a common bird; but is perhaps most plentiful at 10,000 ft., just where the tree-heaths and bamboos intermingle, and it is absolutely confined to that belt. 'The male has a short bright song, and, when in full plumage, is a very handsome bird. When courting, it gives quite a miniature display before the female, hopping around her with its wings drooping and quivering, and with the two beautiful yellow pectoral plumes raised and spread like fans at right angles to the body. It is a curious fact that, except for its larger size, this Sun-bird exactly resembles in every detail C. reichenowi, a species which is found $3000 \mathrm{ft}$. lower dowu the mountains, and which also inhabits the surrounding plains. Possibly this increase in size is the result of the cooler climate at higher altitudes. $-R . B . W$.]

Cinnyris reicienowi Sharpe.

Cinnyris reichenowi Shelley, B. Afr. ii. p. 82 (1900) ; Reich. Vög. Afr. iii. p. 490 (1905); Jackson, Ibis, 1906, p. 556 [Ruwenzori].

a. c. Mubuku Valley, E. Ruwenzori, $6000 \mathrm{ft} ., 28$ th Dec. [No. 3056. R. B.W.]

b-e. o․ $\quad$ " $\quad 6000-7000 \mathrm{ft} ., 2$ nd-17th Jan. [Nos. 71. R. E. D.; 1094. D. C. ; 2090. G. L.; 3062. R. B.W.] 
$f, g . \delta$. M . Mubuku Valley, E. Ruwenzori, 6000-7000 ft., 11th \& 25th Feb. [Nos. 175.R. E. D.; 1227. D.C.]

h-t. of o et o imm. Mubuku Valley, E. Ruwenzori, 6000-8000 ft., 7th-26th March. [Nos. 190. R. E. D. ; 1302, 1317, 1327, 1362. D. C.; 2186, 2200. G. L.; 3205, 3249 , d. $3253,3255,3262 . R . B . W$.

Adult male and female. Iris dark brown; bill and feet black.

'This species is very closely allied to the form inhabiting Cameroon and Fernando Po, which has been named $C$. preussi Reichenow, and may perhaps be distinguished from C. reichenowi by having the outer webs of the wing-coverts and quills edged with brighter olive. There is no difference in the length of the wing-measurement, which, in a large series of specimens from Ruwenzori, Kisumu, and Nandi, varies from 55 to $57 \mathrm{~mm}$.

I have little doubt that $C$. preussi should be added to the synonymy of the present species; but I have only been able to examine three male examples of the Western form.

'The female of this species does not appear to have been described; but it agrees with the description of the female of $C$. prenssi given by Dr. Reichenow, except that the throat and crop are said to be grey, whereas in the present species they are olive like the rest of the underparts.

[Reichenow's Double-collared Sun-bird was met with between Entebbe and Ruwenzori. It was plentiful on the east side of the range up to an elevation of $7000 \mathrm{ft}$., and was occasionally seen as high as $8000 \mathrm{ft} .-R . B . W$.

\section{CinNyris Regius Reichenow.}

Cinnyris regius Shelley, B. Afr. ii.p. 86 (1900) ; Reich. Vög. Afr. iii. p. 491 (1905); Jackson, Ibis, 1906, p. 557 [Ruwenzori].

$a-l$. o f et of imm. Mubuku Valley, E. Ruwenzeri, 6000-9000 ft., 9th-26th Jan. [Nos. 105, 113. R. E. D.; 1129, 1142, 1159, 1160, 1161, 1162, 1186. D. C. ; 2082. G. L.; 3090. R. B.W.]

m-o. đ*. Mubuku Valley, E. Ruwenzori, 7000-9000 ft., 2nd-10th Feb. [Nos. 1212. D. C.; 2140. G. L.; 3160. R. B.W.]

$p-a^{\prime}$. o q et o imm. Mubuku Valley, E. Ruwenzori, 6000-9000 ft., 4th-23rd March. Nos. $1288,1289,1292,1329,1360,1361,1373$. D. C. 2184. G. L.; 3198, 3221 , ‥ $222,3254, R . B . W$.

$Z^{\prime}-d^{\prime}$. o 오. Mubuku Valley, E. Ruwenzori, 7000-1000 ft., 2nd \& 6th April. [Nos. 2264, 2278. G. L.; 3268. R. B.W.] 
e. ․ Butagu Valley, W. Ruwenzori, $7000 \mathrm{ft} ., 1$ st Aug. [No. 1765. D. C.]

Adult male and female. Iris dark brown or dark hazel; bill and feet black.

As neither Captain Shelley nor Dr. Reichenow gives a description of the female of this fine Sun-bird, I take this opportunity of doing so.

Adult female. General colour above greyish-olive, the feathers of the crown with dusky middles; superciliary stripes, cheeks, and underparts pale olive, washed with yellow on the middle of the abdomen; wings greyish-black, both the quills and coverts margined on the outer web with tawny olive; under wing-coverts white tinged with yellow; axillaries and edge of shoulder pale yellow; tail-feathers black. Wing 1.9-1.95 inch; tail 1.4 .

The large series of thirty specimens includes three immature males moulting into the adult plumage; two of these were procured on the 11th and 15th of January respectively, and a third was killed on the 12 th of March.

[The Red-breasted Wedge-tailed Sun-bird is found on Ruwenzori from an elevation of 6000 to $10,000 \mathrm{ft}$.; but it is most numerous in the forest-zone between 7000 and $8500 \mathrm{ft}$. The male sings a short sparkling soug, which one is often surprised to hear in the darkness of the forest and in the mist at $10,000 \mathrm{ft}$.

At present this species is known only from Ruwenzori; but, although no specimen was obtained, Mr. Carruthers assures me that he saw and heard it among the bambooforests at $8000 \mathrm{ft}$. on the Mufumbiro Volcanoes, which lie to the south of Lake Edward. There, it may be noted, he obtained a specimen of Tarsiger ruwenzori, a species previously known only from Ruwenzori.- $R . B . W$.]

Family D I C E I D E.

Pholidornis denti Grant. (Plate XIII. fig. 1, o̊.)

Pholidornis denti Grant, Bull. B. O. C. xix. p. 41 (1907).

a,b. o ?. Avakubi, E. Congo Forest, $2500 \mathrm{ft.}, 31$ st Oct. [Nos. 578, 579. R.E.D. Types of the species.]

This fine new species is most nearly allied to P.rushice(Cass.), but is easily distinguished by having the lower back, rump, and upper tail-coverts, as well as the lower breast, belly, and under tail-coverts, of a much brighter yellow; and the feathers of the mantle, wing-coverts, and scapulars with conspicuous pale sandy margins. As in $P$. bedfordi Grant, the outer margins of the quills are uniform black and not edged with olive, as in $P$.rushio. Iris crimson in the male, grey in the female; upper mandible black, lower mandible yellow with the tip black; feet yellow.

Male. Total length ca. $3 \cdot 1$ inches; wing 1.9 ; tail 0.95 ; tarsus 0.51 .

Female. " $\quad 3.2 \quad$; " $1.9 ;, 1.0$; " 0.52 .

The male is marked by Mr. 1)ent as "breeding." 
[A pair of this beautiful little Flower-pecker were shot in the Congo Forest near Mawambi by Mr. R. E. Dent. 'They frequent the tops of the tall trees, and, though probably not uncommon, are very difficult to get.- $R . B . W$.]

\section{Family Z OS TE R O P I D E.}

\section{Zosterops Jacksoni Neumann.}

Zosterops jacksoni Shelley, B. Afr. ii. p. 184 (1900) ; Reich. Vög. Afr. iii. p. 430 (1905).

Zosterops scotti Neumann, Reich. t. c. p. 431; Jackson, Ibis, 1906, p. 554 [Ruwenzori].

a. 8. Mubuku Valley, E. Ruwenzori, $6000 \mathrm{ft} ., 28$ th Dec. [No. 3057. R. B. W.]

b-q. o ㅇ. Mubuku Valley, E. Ruwenzori, 6000-8000 ft., 1st-26th Jan. [Nos. 69, d. d. d. d.

87, 111, 132. R. E. D.; 1102, 1111, 1172.D.C.; 2045, 2052, 2081, 2087. G. L.; $3077,3078,3096,3120$. R. B. W. $]$

$r-u$. o. Mubuku Valley, E. Ruwenzori, 6000-8000 ft., 10th-16th March. [Nos. 1357,

135S. D.C.; 2185 . G. L. ; 3199.R.R.W.]

v. ‥ Butagu Valley, W. Ruwenzori, $7000 \mathrm{ft} ., 1$ st Aug. [No. 3521. R. B.W.]

w. o . Mpanga Forest, $5000 \mathrm{ft} ., 16 \mathrm{th}$ Sept. [No. 3568. R. B.W.]

Adult male and female. Iris dark brown; bill black; feet blackish, brown, or greenish-grey.

After a careful examination of a very large series of Zosterops from Ruwenzori, Toro, Uganda, and Kavirondo, I agree with Capt. Shelley that Z. scotti Neumann, frow Ruwenzori, cannot be separated from $Z$. jacksoni Neumann, from Mau, Nandi, Elgon, \&c.

An unusually small and brightly-coloured male was procured in the Mpanga Forest. In this specimen the wing measures 2.25 inches and the tail 1.55 ; whereas in most of the males from Ruwenzori the wing measures $2.4-2.5$ inches and the tail 1.8 ; one bird, however, from the latter locality closely approaches the bird from the Mpanga Forest in size, having the wing $2 \cdot 3$ inches and the tail $1 \cdot 6$.

[Jackson's White-eye was found on Ruwenzori at elevations of from 5000 to $10,000 \mathrm{ft}$. It was very plentiful in the forest-zone, and perhaps the most numerous bird in the mountains. It was also plentiful in the Mpanga Forest, but was not seen in the Congo Forest. $-R . B . W$. 


\section{Family PARID}

Parus funereus J. \& E. Verreaux.

Parus funereus Shelley, B. Afr. ii. p. 227 (1900) ; Reich. Vög. Afr. iii. p. 510 (1905).

Parus nigricinereus Jackson, Ibis, 1899, p. 638, pl. xiii. [Nandi].

a. o imm. 40 miles N. of Fort Beni, Semliki Valley, $3500 \mathrm{ft}$, 13th Aug. [No. 1780. D. C. $]$

b. o. Mpanga Forest, Fort Portal, $5000 \mathrm{ft}$., 18th Sept. [No. 531. R. E. D.]

Adult male. Iris crimson; bill and feet black.

Immature male. Iris reddish-brown; bill black; feet dark grey.

The adult male agrees perfectly with the type-specimen of $P$. finereus from Gaboon. The immature specimen from Fort Beni is in the stage of plumage described by Mr. Jackson as $P$. nigricinereus.

[A few examples of the Dusky Black Titmouse were seen in the Eturi Forest and also in the Mpanga Forest, to the east of Ruwenzori. 'They were always observed high up in the tree-tops.- $R . B . W$.]

\section{Parus insignis Cabanis.}

Parus insignis Shelley, B. Afr. ii. p. 231 (1900); Grant, Ibis, 1905, p. 206 [Mulema, S. Uganda]. Parus niger insignis Reich. Vög. Afr. iii. p. 512 (1905).

Pentheres leucomelas Jackson (nec Rüpp.), Ibis, 1906, p. 554. [T'oro].

$a-d$. o o 우 et o imm. Mokia, S.E. Ruwenzori, $3400 \mathrm{ft}$. 2nd-22nd May. [Nos. 268. R. E. D.; 3393, 3394, 3395. R. B.W.]

e-g. o* 오. Mokia, S.E. Ruwenzori, $3400 \mathrm{ft}$, 3rd-21st June. [No. 1661. D. C.; 3447, d.

3448, R. B. W.]

h. o imm. Mokia, S.E. Ruwenzori, $3400 \mathrm{ft.,} 7$ th July. [No.1722. D. C. ]

Adult male und female. Iris dark brown; bill and feet black.

The series includes both old and young birds. The latter have the plumage of the upperparts black, almost devoid of gloss, and the underparts brownish-black; whereas in the adult both the upper- and underparts are black, strongly glossed with greenish.

As already pointed out in my paper on the Doggett Collection from S. Uganda, the range of the present species extends much further north than had been supposed by Captain Shelley or Dr. Reichenow.

A male bird from 'Toro (No. 995) has been referred by Mr. Jackson to P. leucomelas Rüpp., but is really referable to the present species.

There axe a number of examples of the true P. leucomelas in Mr. Jackson's collection from Entebbe, Elgon, \&c. The species is easily distinguished from $P$. insignis by having the feathers of both the upper- and underparts black glossed with purplishblue, instead of dull oily green. 
[Cabanis's Black Titmouse was met with throughout the acacia-country on the plains around the south end of Ruwenzori. It was, comparatively speaking, a rare species on the east side of the range, but on the west, in the Semliki Valley, it was one of the commonest birds. $-R . B . W$.

Parus fascilventer Reichenow.

Parus fasciiventer Reich. Orn. Monatsb. i. p. 31(1893) ; id. Vög. Afr. iii.p. 515 (1905).

Parus fasciiventris Shelley, B. Afr. ii. p. 237 (1900).

Pentheres fasciiventer Jackson, Ibis, 1906, p. 553 [Ruwenzori].

$a-e . \delta$ et $\sigma^{*} \mathrm{imm}$. Mubuku Valley, Eastern Ruwenzori, 6000-8000 ft., 6th-23rd Jan. [Nos. 84.R.E. D.; 1107, 1145, 1146, 1182. D.C.]

$f-k$. o $q$. Mubuku Valley, E. Ruwenzori, 6000-10,000 ft., 1st-25th Feb. [Nos. 270. D. C.; 2142, 2167, 2168. G. L.; 3143. R. B. W.]

l-p. of o et o imm. Mubuku Valley, E. Ruwenzori, 6000-8500 ft., 8th-25th March. [Nos. 197, 198, 214. R. E. D.; 1412. D.C.; 2246. G. L.]

Adult male and female. Iris brown or dark brown; bill black; feet blue-grey or slate-grey (in one example, olive-green).

A fine series of this Titmouse was collected on Ruwenzori. The species is apparently peculiar to the range. On the 13th of January Mr. Carruthers procured a male (No. 1146), which he has marked "breeding."

A quite young bird (No. 198) differs from the adult in having the feathers of the occiput and nape brownish edged with black (instead of uniform black); the chin and middle of the throat black; the cheeks, sides of the head and throat, as well as the chest, greyish-brown (in the adult all these parts are black). The rest of the underparts whitish-buff, inclining to tawny on the flanks (instead of white); the black stripe down the middle of the breast indicated by a few blackish feathers; the light margins of the quills and wing-coverts yellowish-white (instead of pure white). 'The outer pair of tail-feathers are much shorter than the middle pair; whereas in the adult they are of nearly the same length.

[The Grey-backed White-breasted 'Tit was found on Ruwenzori from the forest-line at about 6500 feet up to an elevation of 11,000 feet, where it frequented the tree-heaths. It was, however, but rarely seen as high as this, and only when it had ascended the valleys. It is really a bird of the forest-zone, where it is not uncommon.- $R . B . W$.]

Anthoscopus roccatil Salvad. (Plate XIII. fig, 2, o .)

Anthoscopus roccatii Salvad. Boll. Mus. Tor. xxi. no. 542, p. 2 (1906) [Entebbe].

$a-d$. of f. Mokia, S.E. Ruwenzori, $3400 \mathrm{ft} .$, 10th-23rd May. [Nos. 1610. D. C. ; d. $3346,3347,3348 . R$. B. W. $]$ 
e,f. o* Mokia, S.E. Ruwenzori, 3400 feet, sth July. [Nos. 479. R. E. D.; 1725. l). C.]

Adult male and female. Iris dark hazel or dark brown; bill dusky, bluish-grey, or black; feet grey, dark grey, or dark blue.

The above-mentioned series collected at Mokia is apparently similar to specimens from Entebbe which have been described by Count Salvadori under the name $A$. roccatii.

This is quite a distinct species, but perhaps most nearly allied to $A$. punctifrons (Sundev.) from North-east Africa and to A. capensis (Gmel.) from S. Africa.

It has the colour of the upperparts of a dark olive-green; in A. punctifrons they are yellowish-olive and in $A$. capensis brownish-olive: the underparts are pale yellowish-white, intermediate in colour between the almost white-breasted A. punctifrons and the yellow-breasted $A$. capensis. From both these species it may be easily distinguished by having the fore part of the forehead yellow, with no trace of black tips to the feathers, and though sume of these are more or less indistinctly tipped with greyish, the forehead has a uniform yellow appearance.

[A very few examples of Roccati's Penduline Titmouse were seen among the acaciatrees on the plains around the south end of Ruwenzori. $-R, B . W$.

\section{Family LAN I I D}

Nilaus camerunensis Neumann.

Nilaus nigritemporalis Jackson (nec Reich.), Ibis, 1906, p. 552 [Toro].

Nilaus afer camerunensis Neum. J. f. O. 1907, p. 364.

a. o*. Mokia, S.E. Ruwenzori, $3400 \mathrm{ft}, 29$ th April. [No. 255. R. E. D.]

$b-d . \delta$ f . Mokia, S.E. Ruwenzori, $3400 \mathrm{ft}$., 8th-29th May. [Nos. 381, 382. R. E.D.; 2350. G. L.]

$e-i$. of $q$ et o imm. Mokia, S.E. Ruwenzori, $3400 \mathrm{ft}$., 1st-26th June. [Nos. 1660 , d.

1677, 1691. D. C.; 3437, 3438. R.B.W.]

Adult male and female. Iris dark brown (in one specimen olive-brown); bill black, grey at the base of the lower mandible; feet bluish, bluish-black, or dark grey.

I have referred the above-mentioned specimens with some doubt to $N$. camerunensis Neum., which was founded on a single female specimen from South Cameroon. The females from Ruwenzori agree fairly well with the description of that bird, and there is no reason geographically why they should not belong to the same species; but before this point can be definitely settled it will be necessary to compare adult male specimens from the two localities. The males from S.E. Ruwenzori, on the whole, most nearly resemble $N$. minor Sharpe, and, as in that species, the markings on the sides form a 
confluent longitudinal band, not streaks as in $N$. afer, though they are of the same deep chestnut-colour; in $N$. minor they are light reddish-chestnut. It is, of course, quite possible that the birds from S.E. Ruwenzori may prove to be a distinct form, but until males from Cameroon are available for comparison this question cannot be settled. Birds of this genus appenr to be rare and local, and are comparatively seldom procured. Hitherto Mr. Bates has not sent home a single specimen from West Africa.

The wing-measurement in four adult males from S.E. Ruwenzori varies from $3 \cdot 15$ to 3.25 inches; in two adult females it measures 3.15 and 3.35 inches respectively. Three young birds (a male and two females) differ from the adult female in having the greater wing-coverts tipped with pale whitish-buff and the throat slightly streaked with blackish. In the youngest specimen (a male) the under tail-coverts are buff with a few black cross-bars, while the white feathers down the middle of the back have a hlack subterminal bar.

Two quite young specimens from Toro have been regarded by Mr. Jackson as adult specimens of $\boldsymbol{N}$. nigritemporalis Reich., but they are really referable to the present form, which belongs to the group with the white eyebrow-stripe.

[This Bush-Shrike is not uncommon throughout the acacia-country around the south end of Ruwenzori and in the Semliki Valley, $-R . B . W$.]

'Teuepironus emini Reichenow.

Pomatorhynchus australis emini Reich. Vög. Afr. ii. p. 547 (1903).

a. ơ. Mubuku Valley, E. Ruwenzori, $6000 \mathrm{ft}, 29$ th Dec. [No. 3060. R. B. W.

b-d. ․ ․ $\quad, \quad, \quad 5$ th-20th Jan. [Nos. 1114. U. C. d. 2059, 2100. G. L.]

e. o. Mubuku Valles, E. Ruwenzori, 5000 ft., 27 th March. [No. 2252. G. L.]

t. ․ $\quad " \quad, \quad$ 4th April. [No. 2270.G. L.]

$g, h . \delta$. Mokia, S.E. Ruwenzori, 3400 ft., 14th \& 31 st May. [Nos. 324,400.R.E. D.]

Adult male and female. Iris hazel, dark brown, purple-brown, or slate; bill black; feet slate-colour.

[Emin's Bush-Shrike was not uncommon along the lower slopes of Ruwenzori and on the plains below : a few were seen up to an elevation of 6000 feet. 'The species was breeding at the end of December.-R. B. W.]

'Telephonus erytmopterus Shaw. (Plate XIX. figs. 21 \& 23, eggs.)

Pomatorhynchus senegalus Reich. Vüg. Afr. ii. 1. 547 (1903); Jackson, Ibis, 1906, p. 552 [Toro].

a,b.o f. Mubuku Valley, E. Ruwenzori, $5000 \mathrm{ft}$, 27th Narch. [Nos. 1422. D. C.; 2253.G. L.]

c. $0^{3}$. South Ruwenzori, $3000 \mathrm{ft} ., 24 \mathrm{th}$ April. [No. 232. K. E. D.] vol. xix.--PART IV. No. 45.-March, 1910. 
d-7. o ․ . Nokia, S.E. Ruwenzori, $3400 \mathrm{ft.}$ 26th \& 27th April. [Nos. 238, 241.

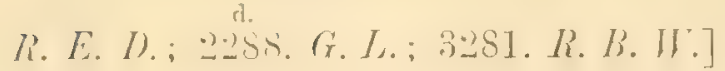

h-l. of ․ Mokia, S.E. Ruwenzori, $3400 \mathrm{ft} ., 2$ 2nd-9th May. [Nos. 273, 281. R.E.D.; 1481. D. C.; 2354 . G. L.] m-o. o ․ Mokia, S.E. Ruwenzori, 3400 ft., 3rd-16th June. [Nos. 429. R. E. D.; 2405. G. L.; 3445. R. B.W.]

Adult male and fomale. Iris bluish-grey, purple-grey, dark grey, or dark brown; bill black; feet slate-colour or bluish.

Prof. Neumann ( $c f$. J. f. O. 1907, pp. 371-378) has written an elaborate account of T. senegalus and its allies, and he recognizes 13 subspecies, of which no less than 5 are described as new. I have examined the extensive material in the British Museum and compared the specimens with his paper, but am unable to agree with his conclusions. 'The birds procured by the Ruwenzori Expedition appear to be indistinguishable from specimens from the Transvaal \&c. (T. s. erythropterus apud Neumann) and from Cameroon and Gaboon (T.s.cumerumensis). Like them they have the posterior half of the eycbrow-stripe rufous-buff, whereas in the true $T$ '. senegalus it is white.

'Three egrgs are of a slightly pointed oval form and somewhat glossy. They are white with irregular dashes, dots, streaks, and blotches of dull maroon-red and purplishgrey, the markings being more or less concentrated into a zone round the larger end. They measure respectively $\cdot 95 \times \cdot 7 ; \cdot 91 \times \cdot 69 ; \cdot 9 \times \cdot 69$ in.

[This Bush-Shrike was very numerous throughout the acacia-country around the south end of Ruwenzori and in the Semliki Valley. It was found breeding in May and June. 'The nest, which was placed in a low acacia-bush about three feet from the ground, was composed of small sticks and roots, and lined with fine roots. It contained three eggs. $-R . B . W$.

\section{'Telepionus minutus Hartlaub.}

Pomatorhynchus minutus Reich. Vög. Afr. ii. p. 552 (1903).

Antichromus minutus Jackson, Ibis, 1906, p. 553 [Toro].

T'elephonus minutus minutus Neumann, J. f. O. 1907, p. 368.

a. ․ 150 miles W. of Entebbe, $5000 \mathrm{ft.}, 12$ th Dec. [No. 1058. D. C.]

b. o. Mubuku Valley, E. Ruwenzori, 6000 ft., 21st March. [No. 2227. G. L.]

c. o . South Ruwenzori, $3000 \mathrm{ft}$., 19 th June. [No. 2409. G. L.]

Adult male and female. Iris mauve or light claret-colour; bill black; feet bluishsrey or olive-grey.

[A few eximples only of the Lesser Bush-Shrike were seen on the eastern slopes of Ruwenzori, and again on the plains near Lake Iidward. It was not a common bird. $-R . B . H$. 
Nicator chloris (Less.).

Nicator chloris Reich. Vög. Afr. ii. p. 554(1903); Jackson, Ibis, 1906, p. 552 [Toro]; Grant, Ibis, 1908, p. 292 [Ponthierville, Upper Congo].

$a-c$. of et of imm. Fort Beni, Semliki Valley, $3000 \mathrm{ft}$, 20th-22nd July. [No. 487.

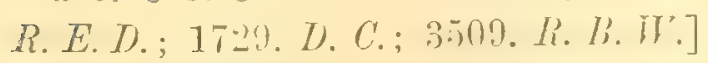

d. ․ 50 miles N. of Fort Beni, 3500 ft., 15th Aug. [No. 1784. D. C.]

e. o. Mpanga Forest, Fort Portal, 15th Sept. [No. 517. R. E. D.]

Adult male and female. Iris hazel or dark brown; bill black; feet slate-grey, grey, or dark grey.

The male is very much larger than the female.

Male. Wing $4 \cdot 2-4 \cdot 25$ inches.

Female. Wing 3.55 inches.

The male (No. 487) is marked by Mr. Dent " breeding."

[The Spot-winged Bush-Shrike was plentiful throughout the Eturi Forest, and a few were seen in the Mpanga Forest, east of Ruwenzori. It frequented both the undergrowth and the tree-tops. The only sound I ever identified as belonging to this bird was a loud, harsh, chattering note. $-R . B . W$.]

\section{Laniarius simuls (Smith).}

Chlorophoneus sulfureopectus chrysogaster Reich. Vög. Afr. ii. I). 562 (1903).

Laniarius sulphureipectus Grant, Ibis, 1905, p. 203 [S. Uganda].

Chlorophoneus chrysogaster Jackson, Ibis, 1906, p. 550 [Toro ; Ankoli].

Laniarius similis Grant, Ibis, 190\%, [1. 589 [Baro River].

a. o. Mubuku Valley, E. Ruwenzori, $5000 \mathrm{ft}$., 28th Feb. [No. 3182. R. B. W.]

$b-$ d. of o et imm. Mokia, S.E. Ruwenzori, $3400 \mathrm{ft.}, 24 \mathrm{th}-28$ th April. [Nos. 235. R.E. D.; 1446. D. C.; 2291. G. L.]

e-l. o ․ Mokia, S.E. Ruwenzori, $3400 \mathrm{ft.}$, 1st-19th May. [Nos. 1471, 1490, 1491,

1501. D. C. ; 2357. G. L.; 3303, 3355. R. B. W.]

$m, n$. ‥ Mokia, S.E. Ruwenzori, $3400 \mathrm{ft} .$, 1st \& 17 th June. [Nos. 405. R. E. D.; d.

$2 \pm 0$. G. L.]

Notes on this species will be found in my paper on the collection of birds from the Sobat and Baro Rivers, quoted above.

[The Yellow-fronted Bush-Shrike was not uncommon in the acacia-country around the south end of Ruwenzori and on the lower slopes of the mountains up to $5500 \mathrm{ft}$. Ii. IS. H. I 
Laniarius erythrogaster (Cretzschm.). (Plate XIX. fig. 22, egg.)

Laniarius erythrogaster Reich. Vög. Afr. ii. p. 586 (1903); Jackson, Ibis, 1906, p. 55] ['Toro]; Grant, Ibis, 1907, p. 589 [White Nile, Sobat, and Baro Rivers].

$a-c$. o ㅇ․ $70-80$ miles W. of Entebbe, 3500-3600 ft., Ist Dec. [Nos. 1021, 1022. II. C.; :301s. R. R. II.]

1, e. o 9 . Nokia, S.E. Ruwenzori, $3400 \mathrm{ft} .28$ th April. [Nos. 250. R. E. D.; 2286. G. L.]

$f-v$. o o et $\delta$ imm. Mokia, S.E. Ruwenzori, $3400 \mathrm{ft.}$, 4th-29th May. [Nos. 290, $295,337,343,364,365,366,372,373,374 . R . E . D . ; 1492,1493,1583$. D. C. ; d.

2356. G. L. ; 3344, 3361.R.B.W.]

$w-y$. o ㅇ. Mokia, S.E. Ruwenzori, 3400 ft., 2nd-5th June. [Nos. 415, 419, 431. R. E. D.]

Iris cream-colour; bill and feet black.

Several immature birds in the present collection differ from the adult in having the breast-feathers fringed with buff, and a few small feathers at the base of the upper mandible yellow.

Two eggs of this species were procured by Mr. R. B. Woosnam at Mokia on the 11th of May, 1906. They are of a rather pointed form and somewhat glossy. The ground-colour is pale blue, spotted and blotched with umber-brown and lilac-grey, the markings being most numerous round the larger end, where they form a distinct zone. Both measure $\cdot 9 \times \cdot 7$ inch.

[The Scarlet-bellied Bush-Shrike was met with near Entebbe and throughout the journey to Ruwenzori. 'The species was very numerous in the acacia-country at the south end of the range and in the Semliki Valley. Its musical note was one of the most familiar sounds at the south end, but it was never seen on the mountains.li. B. H.]

\section{Laniarius lagdeni Sharpe.}

Laniarius laydeni Sharpe, P. Z. S. 1884, p. 54, pl.v. [Ashanti]; Grant, P. Z. S. 1908, pp. 287, 289 [Ruwenzori and Mufumbiro Volcanoes].

Malaconotus lagdeni Reich. Vög. Afr. ii. p. 600 (1903).

a. .. Mubuku Valley, E. Ruwenzori, 9000 ft., 29th March. [No. 2259. G. L.]

Iris light grey ; bill black; feet slate-blue.

The type-specimen of this extremely rare species was procured by Sir Godfrey Lagden in Ashanti in 1883, and, so far as $I$ am aware, has remained unique till it was again met with by the Ruwenzori Expedition in 1906.

Its occurrence in the highlands of Ruwenzori is very remarkable and of the greatest interest. The present specimen, an adult female, differs from the type only in having 
the throat of a less brilliant orange-yellow and in being siightly smaller. The type is no doubt a male.

The measurements are as follows:-

Type $\left[? 0^{*}\right]$. Ashanti.-Wing $4 \cdot 6$; tail $4 \cdot 15$ inches.

‥ E. Ruwenzori, $9000 \mathrm{ft}$.-Wing $4 \cdot 4$; tail 4.3 inches.

Several additional specimens have more recently been procured by Herr R. Graner on the higher slopes of the Mufumbiro Volcanoes, which lie to the west of Lake Kivu.

[A single female specimen of this beautiful Bush-Shrike was obtained by Mr. Gerald Legge in the Mubuku Valley at an altitude of 9000 feet. It was seen among the tops of some tall trees in company with another bird, probably the male, which unfortunately escaped. These examples were the only ones seen. The ovaries of this female wert slightly enlarged.-R. B. W.]

LANIARIUS MIÁJOR (Hartl.).

Laniarius major Reich. Vüg. Afr. ii. p. 580 (1903); Grant, Ibis, 1908, p. 290 [N.W. of Lake Tauganyika].

थ. ठ. 80 miles W. of Entebbe, $3500 \mathrm{ft}$., 1st Dec. [No. 1022. D. C.]

b. of 100 miles W. of Entebbe, $4000 \mathrm{ft}$, 6 th Dec. [No. 30. R. E. D.]

$c$, r. ㅇ․ Mubuku Valley, E. Ruwenzori, 6000 and $6500 \mathrm{ft}$, 16th \& 21st Jan. [Nos. 2103. G. L.; 3112.R. B. W.]

Adult male and female. Iris reddish-brown or dark hazel; bill black; feet slategrey or black.

[The Greater Bush-Shrike was met with here and there between Entebbe and Ruwenzori, and on the mountains it was occasionally met with up to an elevation of 6500 feet. $-R . B . W$.

\section{LANTARIUS LÜHDERI (Reichenow).}

Laniarius lïhderi Reich. Vög. Afr. ii. p. 584 (1903).

Dryoscopus coronatus Sharpe, P. Z. S. 187.4, p. 205, pl. xxxiii, fig. 2 [Gaboon].

Laniarius castaneiceps Sharpe, Ibis, 1891, pp. 445, 598 [MIt. Elgon].

$a-c .0$ o . Mpanga Forest, Fort Portal, 5000 ft., 1Sth-24th Sept. [Nos. 537, 557.R.E. D.; 3609.R.B.W.]

Adult male. Iris dark brown; bill black; feet blue-grey.

Adult f'emale. Iris crimson; bill and feet black.

In the figure of this species given in the 'Proceedings of the Zoological Society, the crown is incorrectly coloured, and should be of a dark chestnut, quite different from the breast. In the male (No.3609) the light tips of the medinn wing-coverts are mostly pale yellow; one of the females (No.537) shows traces of yellow, but in the second female (No.557), which is marked "breeding," the tips of the median wingcoverts are pure white, as is the case in all other specimens in the British Museum. 
Dr. Sharpe has described an immature female (the type of $I_{\text {. }}$ castaneiceps) as having the "median wing-coverts dusky, tipped with white, slightly tinged with yellow, and forming a band"; so probably the yellow tips to these feathers in the male in the present collection indicate traces of immaturity.

[A few examples of Lühder's Bush-Shrike were seen in the Mpanga Forest, east of Ruwenzori.-R. B.W.]

\section{Dryoscopus malzacii Heugl.}

Dryoscopus cinerascens Reich. Vög. Afr. ii. p. 596 (1903); Jackson, Ibis, 1906, p. 552 [Toro; Ruwenzori].

Dryoscopus malzacii Grant, Ibis, 1907, p. 588 [Baro River].

a. o . 120 miles W. of Entebbe, $4200 \mathrm{ft.}$, 8th Dec. [No. 1050. D. C.]

b. o . Mubuku Valley, E. Ruwenzori, $6000 \mathrm{ft.,22nd} \mathrm{Jan.} \mathrm{No.} \mathrm{2108.} \mathrm{G.} \mathrm{L.]}$

c. o $\quad " \quad, \quad 6000 \mathrm{ft}$., 1st Feb. [No. 2131. G. L.]

d,e. 웅. ",$\quad 7000 \mathrm{ft}$, 14th Narch. [Nos. 3213, 3214.

R. B. W.

f. ठ imm. Mubuku Valley, E. Ruwenzori, 5000 ft., 3rd April. [No. 2265. G. L.] g-p. of $q$ et o irnm. Mokia, S.E. Ruwenzori, $3400 \mathrm{ft} ., 1 \mathrm{st}-21 \mathrm{st}$ May. [Nos. 3233. R. E. D. ; 1539, 1571. D. C. ; 2331, 2378, 2379. G. L.; 3302, 3311, 3312. R. B. W.]

q, r. o. Mokia, S.E. Ruwenzori, $3400 \mathrm{ft}$., 16th \& 27 th June. [Nos. 1698. D. C.; 3195.R.B.W.]

s. $\sigma^{7} \mathrm{imm}$. Mokia, S.E. Ruwenzori, $3400 \mathrm{ft.}$, 2nd July. [No. 472. R.E. D.]

t. q. Lower Semliki Valley, $2500 \mathrm{ft} ., 11$ th Oct. [No.563. R. E. D.]

[A few examples of this Bush-Shrike were seen at the north and south ends of Ruwenzori among the acacia-trees. On the mountains it was seen in the Luimi and Mubuku Valleys as high as $6500 \mathrm{ft}$., but it was always rather a rare bird. It has a very curious note, quite unlike that of any other Shrike, $-R . B . W$.

\section{Dryoscopus nandexsis Sharpe.}

Dryoscopus nandensis Sharpe, Ibis, 1901, p. 41, pl. ii. fig. 1 [Nandi].

Dryoscopus anyolensis nandensis Reich. Vög. Afr. ii. p. 590 (1903).

a. o. Irumu, Eturi Forest, $3000 \mathrm{ft.,}$ 16th Oct. [No. 3627. R. B.W.]

Iris dark brown; bill black; feet dull flesh-colour.

The type of this species from Nandi is a somewhat immature bird, as may be seen by the buff margins to some of the secondary-quills and the buff feathers among the axillary plumes, as well as the pale horn-coloured tip and edges of the lower mandible.

In the adult the inner margins of the quills and the axillary plumes are greyishwhite and the lower mandible is entirely black. 
MIr. Woosnam states that this Puff-back Shrike was shot among the tree-tops and that the specimen procured was the only one met with during the journey.

Dryoscopus afFinis (G. R. Gray).

Dryoscopus affinis Reich. Vög. Afr. ii. p. 590 (1903); Grant, Ibis, 1908, p. 290 [Ponthierville, Upper Congo].

a. ․ Mawambi, E. Congo Forest, 3000 ft., 27 th Oct. [No. 3644. R. B. W.]

Iris orange; bill black; feet grey.

This specimen, with its white lower back and pale grey rump, is a typical example of $D$. affinis, which, according to Reichenow, is the East African representative form. As already, remarked in my paper referred to above, it is very doubtful whether the West African examples, which have been separated under the name of $D$. senegalentsis (Hartl.), are really distinct from $D$. affinis.

[A single example of this Puff-back Shrike was obtained in the Congo Forest near Marambi, but its note was frequently heard high up in the trees. $-R, B . W$. ]

DRYOSCOPUS HoLOMELAS Jackson.

Dryoscopus holomelas Jackson, Bull. B. O. C. xvi. p. 90 (1906); id. Ibis, 1906, p. 551 [Ruwenzori].

$a-l$. o ㅇ․ Mubuku Valley, E. Ruwenzori, 6000-9000 ft., 9th-27th Jan. [Nos. 78, 119. R. E. D. ; 1123, 1124, 1137, 1164. D. C. ; 2075, 2106, 2115, 2124. G. L.; $308 S$. li. B. W.]

m. ㅇ. Mubuku Valley, E. Ruwenzori, $7000 \mathrm{ft} ., 24$ th Feb. [No. 3177. R. B.W.] n-r. $\delta^{*}$. $\quad " \quad$ 6000-8000 ft., 5th-24th March. [Nos. 189. R. E. D. ; 2239, 2240. G. L. ; 3207, 3247.R. B. W.

s. o*. Butagu Valley, W. Ruwenzori, $7000 \mathrm{ft} .$, st Aug. [No. 3526. R. B. W.]

Iris dark brown or reddish-brown; bill and feet black.

This small-billed species is quite distinct from D. lencorhynchus (Hartl.), and has the black plumage of a rather duller and greyer shade, while in the latter it is purplishblack.

All the specimens procured by the Expedition appear to be fully adult birds with black bills.

[This Black Bush-Shrike was found on Ruwenzori at elevations of from 6000 to $9000 \mathrm{ft}$. It is really a bird of the forest-zone, but it is occasionally met with lower down as well as in the bamboo-zone above. It has the most marvellously versutile range of notes it is possible to imagine. From the depths of some tangled mass of creepers one might hear, first a low harsh scraping or chattering sound, followed by some of the most beautiful flute-like notes. After a moment or two of silence an 
extraordinary clicking sound would commence (such a sound as is made by quickly bending and letting fly the tip of a strong quill tooth-pick), followed by a succession of quick high-pitched piping notes. A search for the performer usually resulted in finding nothing, so cunning were these birds in sneaking away through the undergrowth without being seen, and it was some time before we discovered the author of these strange noises. $-R . B . W$.

Dryoscopus Leucornyncius Hartl.

Laniarius leucorhynchus Reich. Vög. Afr. ii. p. 573 (1903); Sharpe, Ibis, 1908, p. 331 [Cameroon].

a. ơ. Fort Beni, Semliki Valley, $3000 \mathrm{ft}$, 18th July. [No. 3502. R. B. W.]

Iris dark brown; bill and feet black.

'The members of the Expedition did not recognize the differences between this species and D. holomelas, which was met with on the west as well as on the east side of liuwenzori, and consequently they did not trouble to procure a series of specimens. Dr. Reichenow states that the white bill in this species is a characteristic of the very old bird; but this is clearly an error, as all the specimens in the British Museum with a white bill are obviously quite young, and in one from Efulen, Cameroon (Bates Coll.), the tail is only partially grown.

\section{Lanius intercedens Neumann.}

Lanius excubitorius intercedens Neumann, J. f. O. 1905, p. 228 [Hawash Valley to Victoria Nyanza].

Lanius intercedens Grant, Ibis, 1907, pp. 590, 591.

$a-f$. o ㅇ et i imm. Mokia, S.E. Ruwenzori, $3400 \mathrm{ft}, 25$ th-30th April. [Nos. d.

1466, 1467.D.C.; 22S5, 2289, 2290, 2307.G.L.]

$g-q$. o $q$ et ơ imm. Mokia, S.E. Ruwenzori, $3400 \mathrm{ft} ., 3 \mathrm{rd}-19 \mathrm{th}$ May. [Nos. 271, $\left.279,288,294,298,322,347,349 . R . E . D . ; 1485,1517 . D . C_{0}\right]$

$r-t$. o 오. Mokia, S.E. Ruwenzori, $3400 \mathrm{ft} ., 4$ th-24th June. [Nos. $457 . R . E . D$. ; 1680.D.C.; 3455. R.B.W.]

Adult male and female. Iris dark brown; bill and feet black.

[Neumann's Long-tailed Grey-backed Shrike was very numerous all through the acacia-country around the sonth end of Ruwenzori and in the upper part of the Semliki Valley. It was a conspicuous object, even from a distance, perched on the topmost bough of an acacia-tree, or flying, as they do, in a perfectly straight line from one tree to another. Its low note has a curiously musical sound, like several notes in harmony. $-R . B . W$. 


\section{LaniUs MaCkinnoni Shatpe.}

Lanius mackinnoni Grant, Nor. Zool. ix. p. 468 (1902); Reich. Vög. Afr. ii. p. 617 (1903).

a. f. Mubuku Valley, E. Ruwenzori, $6000 \mathrm{ft.,} 2$ Sth Dec. [No. 48. R. E. D.]

b, c. 우. " " " $\quad$ 1st \& 20th Jan. [Nos.59.R.E. D.; 3122. R. B. W.]

d, e. o 오. Mubuku Valley, E. Ruwenzori, 6000 ft., 3rd \& 25th Feb. [Nos. 141. R. E. D.; 3181. R. B.W.]

f-h. o ․ . Mubuku Talley, E. Ruwenzori, 6000-6500 ft., 1st-6th March. [Nos. 176. R.E. D. ; 1293, 1301.D.C.]

$i, k$. $\delta$ ㅇ. 10 miles N.W. of Fort Beni, $3000 \mathrm{ft}$, 10 th Aug. [Nos. 2446. G. L.; $3510 . R \cdot B \cdot W$.

Adult male and female. Iris dark brown; bill and feet black.

The specimens killed in August are in very worn plumage and in full moult, the old feathers of the back being much browner than the new ones. 'The collection also contains specimens in partial moult (chiefly the tail-feathers) procured in January, February, and March. A female killed in December [No. 48] is marked "breeding."

[A few examples of Mackinnon's Shrike were met with on Ruwenzori up to the forest-line at an elevation of $6500 \mathrm{ft}$., but they were not numerous. They were also secn in some of the clearings in the Eturi Forest between Fort heni and Irumu.li. B. II.]

\section{Lanivs humeralis Stanley.}

Lanius humeralis Grant, Nor. Zool. ix. p. 466 (1902); Reich. Vög. Afr. ii. p. 609 (1903).

Lanius humeralis congicus Reich. Vüg. Afr. ii. p. 610 (1903).

Fiscus humeralis Jackson, Ibis, 1906, P. 550 [Toro].

a, b. o. Mubuku Valley, E. Ruwenzori, $5000 \mathrm{ft}, 27$ th March. [Nos. 1423. D.C.; 2217. G. L.]

c. o . Mokia, S.E. Ruwenzori, $3400 \mathrm{ft}$, 3rd May. [No. 272. R. E. I.]

Adult male. Iris dark brown; bill black; feet dark grey or black.

Dr. Reichenow considers that the representatives of this species, ranging from Angola to the Lake District, should be separated under the name of L. h. congicus, on account of the markings of their outer tail-feathers, which are said to be black with only the tip and outer web white. In this respect the specimen (No. 272) from S.E. Ruwenzori agrees with the description of $L$. congicus and differs from most East African specimens of $L$. humeralis in the British Museum, which have the greater part of the outer tail-feathers white. These range from North Abyssinia southwards to Natal and westwards to Victoria Nyanza. There is a large series of this species in the Jackson Collection from Kikuyu, Eldoma Ravine, Nandi, Elgeyu, Mt. Elgon, Entebbe, and 'Toro, and, among these, specimens are to be found from several localities with the VOL. XIX.-PART N. No. 46.-Marel, 1910. 
outer tail-feathers marked as in L.congicus. Of the two adult males from Eastern Ruwenzori, one must be referred to typical $L$. humeralis and the other to $L$. congicus, if the difference in the markings of the tail-feathers is to be regarded as of subspecific value, but it seems doubtful if this character is of any great importance. It must, however, be added that in the British Museum there are no specimens from the Congo district for comparison.

[A few examples of the Eastern Fiscal-Shrike were seen on the east side of Ruwenzori, but were not met with above an elevation of $5000 \mathrm{ft} .-R . B$. W. $]$

\section{Family STLIIDE.}

Melocichla mentalis (Fraser).

Melocichla mentalis Reich. Vög. Afr. iii. p. 538 (1905); Grant, 1bis, 1907, p. 594 [Baro River], 1908, p. 298 [Tanganyika].

Melocichla mentalis atricauda Reich.; Reich. Vög. Afr. iii. p. 539 (1905).

a. J. Entebbe, $3500 \mathrm{ft}$, $20 \mathrm{th}$ Nov. [No. 1. R. E. D.]

b-e. o \&. 100-130 miles W. of Entebbe, $4000 \mathrm{ft} ., 6 \mathrm{th}-9$ th Dec. [Nos. 31, 33̈, 41. R. E. D. ; 1053. D. C.]

f-i. of . Mokia, S.E. Ruwenzori, 3400 ft., 28th \& 29th April. [Nos. 1450, d.

1455. D. C.; 2303. G. L. ; 3289. R. B. W.

k-n. o . Mokia, S.E. Ruwenzori, $3400 \mathrm{ft}$., Sth-30th May. [Nos. 303, 393. R. E. I. ; ปร. D. D. . ; 3358.R.B.W.]

$o-u$. of ot ot of imm. Mokia, S.E. Ruwenzori, $3400 \mathrm{ft} ., 2 \mathrm{nd}-30 \mathrm{th}$ June. [Nos. 410.

R.E. D.; 1628, 1629, 1630, 1713, 1714.D.C.; 3477.R. R.W.]

v. Adult. Nokia, S.E. Ruwenzori, $3400 \mathrm{ft.}$, Sth July. [No. 47. R. E. D.]

w. J. Fort Beni, Semliki Valley, $3000 \mathrm{ft}$., 20th July. [No. 2417. G. L.]

Iris cream-colour, yellow, or light brown; bill black, basal part of the lower mandible white or pale slate-colour; feet varying from slate-blue to dark grey.

The two subspecies of this large Grass-Warbler have already been discussed at some length in my paper on the birds from the Sobat and Baro Rivers quoted above. 'I'he splendid series procured by the Expedition, and representing the greater part of the year, includes several immature examples. These may be recognized by the narrow sandy margins to the feathers of the occiput, nape, and mantle, as well as to the secondary quills, but in other respects the plumage is similar to that of the adult.

[This species was seen at Entebbe and throughout the journey to Ruwenzori. It was not uncommon at the north and south ends of the range and was also met with in the Semliki Valley, but it was never seen on the mountains. $-R . B . W$. 
Cisticola rufa (Fraser).

Cisticola rufa Reich. Vög. Afr. iii. p. 567 (1905).

a. o. 80 miles W. of Entebbe, $3800 \mathrm{ft} ., 2$ nd Dec. [No. 3023. R. B.W.]

b. $\delta .120$ miles W. of Entebbe, $4000 \mathrm{ft} ., 8$ th Dec. [No. 3038. R. B. W.]

c, d. o . Fort Portal, $5000 \mathrm{ft} ., 26 \mathrm{th}$ \& 2Sth Sept. [Nos. 3615, 3617. R. B. W.]

e. s. Mokia, S.E. Ruwenzori, $4000 \mathrm{ft}$., 8th May. [No. 1520. D. C.]

Iris pale brown or olive-brown; bill olive-brown, yellowish-brown, or black (in May); feet light brown.

[The small Rufous Grass-Warbler was obtained near Lntebbe and a few were seen at the north end of Ruwenzori. A single specimen was killed at the south end of the range on the bare grassy foot-hills. It was by no means a common bird.- R. B.W.]

Cisticold terrestris (Smith).

Cisticola terrestris Reich. Vög. Afr. iii. p. $558(1905)$.

a. o. Mokia, S.E. Ruwenzori, $3400 \mathrm{ft}, 25$ th April. [No. 1429. D. C.]

b-e. o , , , , 1st-19th May. [Nos. 1515, 1591. D.C.; $3301,3335 . R . B . W$.

$f^{*}-i$. o o. Mokia, S.E. Ruwenzori, $3400 \mathrm{ft}$, 12th-17th June. [Nos. 1641 ${ }^{\mathrm{A}}$. D. C.; 3468, 3470, 3471. R. B. W.]

Iris pale brown, olive-brown, or hazel; bill black, base of lower mandible grey; feet light flesh-colour or pale brown.

[The small Terrestrial Grass-Warbler was a very common species on the plains around the south end of Ruwenzori, especially in the flat open country, where there was no bush. Anyone who has travelled in Africa must be familiar with these little birds, which, rising suddenly from the grass, fly up into the air, and, circling round and round, utter a continuous clicking sound. Sometimes they rise to such a height that they are lost to sight, but even then their clicking note can still be distinctly heard. $-R . B . W$.

\section{Cisticola chreuthersi Grant.}

Cisticola carruthersi Grant, Bull. B. O. C. xxiii. p. 94 (1909).

a. ․ Mokia, S.E. Ruwenzori, $3400 \mathrm{ft}, 17$ th Jume. No. 1640. D. C. Type of the species.]

Iris pale brown; bill black; feet pale brown.

This species is allied to $C$. lugubris, but may be at once recognized by the following points:-The bill is long and slender (as in the genus Camaroptera); the outer webs of the primary-quills are brownish (not rufous); and the whole upper surface of the tailfeathers is black tipped with white, while on the under surface the wide subterminal black bands are scarcely distinguishable from the greyer basal portion of the feathers. Total length ca. 4.8 inches; culmen 0.58 ; wing 2.2 ; tail 2.05 ; tarsus 0.82.

$$
3 \times 2
$$


Cisticoli errtirors (Hartl.). (Plate XIX. fig. 11, egg.)

Cisticola erythrops Reich. Vög. Afr. iii. p. 568 (1905); Sharpe, Ibis, 1908, p. 31 \% [Cameroon].

r. o. 80 miles W. of Entebbe, $3800 \mathrm{ft} ., 2$ nd Dec. [No. 3022. R. B. W.]

b. 3. 150 miles W. of Entebbe, $5000 \mathrm{ft.}, 12$ th Dec. [No. 1057. D. C.]

c. \&. Fort Portal, $5000 \mathrm{ft}$, 28th Sept. [No. 3518.R. B. IV.]

d. \&. Mubuku Valley, E. Ruwenzori, $6000 \mathrm{ft} ., 31$ st Dec. [No. 1077. D. C.]

e,f. of of. Mokia, S.E. Ruwenzori, 3400 ft., 28th April. [Nos. 3286, 3287. R. I. 11 .

g-p. o ․ Mokin, S.E. Ruwenzori, $3400 \mathrm{ft}$. 3rd-25th May. [Nos. 354. R. E. D.; d. d. 1483, 1528, 1595. D. C. ; 2332, 2388. G. L. ; 3310, 3314, 3413.R.B.W.]

$\eta, r^{\circ}$. Nokia, S.E. Ruwenzori, $3400 \mathrm{ft}$, ârd \& 4th June. [Nos. 421. R. E. D.; 3454. R. B. IV.]

s. ơ. Butagu Valley, W. Ruwenzori, $4000 \mathrm{ft.,} 30$ th July. [No. 2440. G. L.]

Iris pale brown, hazel, or olive-brown; upper mandible black, lower whitish or blue-grey; feet pale brown or Hesh-colour.

A pair of birds killed on the 28 th of April (Nos. 3286 and 3287) had a nest with four eggs, which may be described as follows:- Of a regular oval shape and distinctly glossy. The ground-colour pale greenish-blue, spotted and blotched, especially round the larger end where the markings form a zone, with light red and purplish-grey. 'The four eggs measure respectively $69 \times \cdot 51, \cdot 70 \times \cdot 52, \cdot 70 \times \cdot 53, \cdot 71 \times \cdot 53 \mathrm{in}$.

The nest, which was placed in a low bush about three feet from the ground, was formed by fastening three leaves together; it was not domed, but lined with fine grass and the down of plants. It contained four slightly incubated eggs.

[The Buff-breasted Grass-Warbler was seen near Entebbe and throughout the journey to Ruwenzori. It was plentiful on the plains all round the mountains, but wis never met with above $5000 \mathrm{ft}$. It seems chiefly to frequent the small water-courses and streams and the edges of swamps. $-R, B . W$.

Cisticola lateralis (Fraser).

Cisticola lateralis Reich. Vög. Afr. iii. p. 562 (1905).

a. o. Lower Semliki Valley, $2000 \mathrm{ft}$, 10 th Oct. [No. 3623. R. B. W.]

Iris light hazel ; bill dark horn-colour; feet light brown.

[This Grass- Warbler was met with at the extreme north end of Ruwenzori on the spurs projecting into the Semliki Valley near Lake Albert, and also among the acacincountry in the Semliki Valley N.W. of the range. In the field it could be at once distinguished from $C$. chubli-which it resembled in appearance-by its pleasant song, which is composed of loud clcar notes, quite unlike that of any other species of Cisticola 
to be met with in the district. The two species were never found in the same locality, for $C$. lateralis was not seen above $2500 \mathrm{ft}$., while $C$. chubbi was nerer wet with below $5000 \mathrm{ft} .-R . B . W$.

\section{Cisticola emini Reichenow.}

Cisticola emini Reich. J. f. O. 1892, p. 56 [Bussisi, S. of Victoria Nyanza]; Grant, Ibis, 1908, p. 297 [N.W. of Lake Tanganyika].

Cisticola rufopileata emini Reich. Vög. Afr. iii. p. 562 (1905).

Cisticola wonsnami Grant, Bull. B. O. C. xxi. p. 72 (1908).

$a-i . \delta^{*}$ ㅇ․ Molsia, S.E. Ruwenzori, $3400 \mathrm{ft}$., 24 th-30th April. [Nos. 251, 25:2. R.E.D.; 1428, 1440, 1441, 1445, 1459, 1463. D.C.; 3280.R.B.W.]

$k-y$. o $q$ et $\delta^{*}+\mathrm{imm}$. Nokia, S.E. Ruwenzori, $3400 \mathrm{ft}$., 5th-30th May. [Nos. 286, 2 d. $^{\wedge}, 319,328,335,395$. R. E. D. ; 1575. D. C.; 3339, 3340*, 3351, 3353, 3369, $3371 *$ *3384, 3387. R. B.W.]

z. of imm. Mokia, S.E. Ruwenzori, 3400 ft., 2nd June. [No. 3444. R. B.W.]

I have re-examined the large series of Grass-Warblers, which I at first considered to represent a distinct species and separated under the name of $C$. woosnami, and am now satisfied that they should have been referred to $C$. emini Reich.

The species is nearly allied to C. pileata Reich., and, like that species, has the lores white, but the bill is shorter, the culmen more curved, the under mandible always pale horn-colour, the top of the head browner, not chestnut, and the upperparts much lighter and of an olive-brown. Iris hazel; upper mandible black, lower mandible whitish horn-colour; feet flesh-colour.

The male, besides being larger than the female, is easily distinguished by having the sides and flanks olive-grey: in the female these parts are bright buff. This sexual difference in plumage explains the differences noted in the bird collected by Ir. Carruthers at Baraka (cf. ' Ibis,' 1908, p. 297).

Young birds have the upperparts, including the crown, uniformly reddish-brown; the chin, throat, and middle of the breast being washed with yellow, as is usual among young birds of this genus,

8. Total length ca. 5.0 inches; culmen 0.58 ; wing 2.6 ; tail $2 \cdot 1$; tarsus 0.9 .

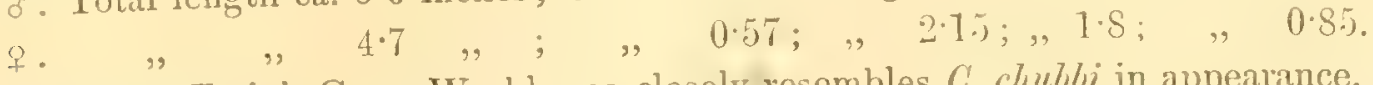

[Although Emin's Grass-Warbler so closely resembles C. clubbi in appearance, both its habits and notes are totally different and it frequents a different kind of country. C. chubbi, which is found on Ruwenzori from 5000 to $8000 \mathrm{ft}$., is essentially a bird of the elephant-grass country, and is never seen among the short grass and acaciatrees at the south end of the range. C. emini is met with only in the acacia-country 
at the foot of the mountains at an elevation of $3400 \mathrm{ft}$., and is never found among the elephant-grass at $5000 \mathrm{ft}$. The note of $C$. emini, which is a curious long trill, is quite unlike that of $C$. chubbi. Both species are very numerous where they occur, but they are never found together. C. emini is a bird of rather retiring habits and is not often seen, except when it utters its curious note. Then the male bird takes up a position in some high acacia-tree and, sitting motionless, gives forth every few minutes a long trill which seems to be ventriloquised, for, as a rule, it is most difficult to locate. $-R . B .[W$.

\section{Cisticola belli Grant.}

Cisticola belli Grant, Bull. B. O. C. xxi. p. 71 (1908).

a. o. Mokia, S.E. Ruwenzori, $3400 \mathrm{ft}$, 31st May. [No.3434. R. B.W. Type of the specics.]

The single male specimen is most nearly allied to $C$. chubbi Sharpe, and as in that species the lores are black, but it differs in the following particulars:- The bill is long and more slender; the back and wing-coverts greyer brown; the tail much shorter (i.e. $54 \mathrm{~mm}$. as compared with $65 \mathrm{~mm}$. in C. chubbi), with the middle pair of feathers conspicuously barred, and the outer pairs tipped with grey and edged with white (not with buff or clay-colour). 'The outer edges of the primary-quills are conspicuously rufous-brown.

From $C$. emini Reichenow, which is also found in the same locality, it may be at once distinguished by having the bill longer and less curved; the under mandible black instead of pale horn-colour; the lores black instead of white; and the back greyer, contrasting with the reddish-brown crown. Iris hazel; bill black; feet light brown.

Total length ca. 5.2 inches; culmen 0.65 ; wing 2.35 ; tail 2.05 ; tarsus 1.0 .

This species is named in honour of Mr. W. A. Bell, one of the Subscribers to the Ruwenzori Expedition.

[A single specimen of Bell's Grass-Warbler was shot in the papyrus-swamp on the edge of Lake Edward at an altitude of $3000 \mathrm{ft}$. In appearance it closely resembles C. chubbi, which is found on Ruwenzori from 5000-\$000 ft., but is never seen in the vicinity of Lake Edward, where the present species occurs. C. lateralis again, which it also resembles, is found at the north end of the range and near Lake Albert, but inhabits the dry acacia-country. A third species, C. emini, which also resembles $C$. belli, is found near the same locality, but inhabits only the dry acaciacountry at the foot of the mountains and is never scen or heard near the papyrusswamps on the lake. 'These three species of Cisticola (C. chubbi, C. lateralis, and C. emini) have distinctive and striking notes, which could not have failed to attract attention if heard in the papyrus-swamp. C. belli was evidently breeding, as the testes in the male procured were much enlarged. Although only one specimen was obtained, others were seen in the same locality. - R. B.W.] 
Cisticola chubbi Sharpe. (Plate XIX. fig. 14, egrg.)

Cisticola chubbi Reich. Vög. Afr. iii. p. 561 (190ă); Jacksou, Ibis, 1906, p. 545 (Ruwenzori); Grant, Bull. B. O. C. xxi. p. 73 (1908).

a-d. o ․ . Mubuku Valley, E. Ruwenzori, $6000 \mathrm{ft} ., 30 \mathrm{th} \& 31 \mathrm{st}$ Dec. [Nos. 58. R. E. D.; 2039, 2041, 2043̈. G. L.]

e-p.o f. Mubuku Valley, L. Ruwenzori, $6000 \mathrm{ft}$. , 1st-28th Jan. [Nos. 125, 133. R. E. D. ; 1082, 1083, 1089, 1099, 1138. D. C. ; 2040, 2123. G. L.; 3110, 3111. R. B. W.]

$q-t$. o $q$. Mubuku Valley, E. Ruwenzori, $6000 \mathrm{ft} .$, Sth \& 11 th Feb. [Nos. 152,

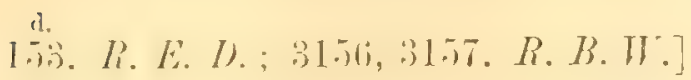

$u-a^{\prime}$. of $q$ et o imm. Mubuku Valley, E. Ruwenzori, 5000-7000 ft., 9th-23rd d.

March. [Nos. 204. R. E. D.; 1334, 1352. D. C.; 2177, 2221. G. L.; 3216, 3252. R. R. II.]

Iris chestnut, hazel, or dark brown; bill black; feet flesh-colour or light brown.

An immature male differs from the adult in having the upperparts reddish-brown, almost like the crown, the dusky subterminal spots to the tail-feathers very indistinct, and the tips of the feathers light rust-colour.

Two eggs are of a regular oval form and sometwhat glossy. The ground-colour is pale blue, very finely marked all over, but especially round the larger end, with light red. 'They measure respectively $78 \times .56$ and $75 \times \cdot 56$ inch.

[Chubb's Grass-Warbler was found on Ruwenzori from $5000 \mathrm{ft}$. up to the forestline and in all the open clearings up to $8000 \mathrm{ft}$. On reaching Ruwenzori this species was one of the first birds to attract attention, not only on account of its numbers and its fearlessness of man, but because of its loud note and curious habits. 'The male birds seem to spend almost the whole day in singing, always two and sometimes three or four joining together. As a rule, however, two are to be seen on a tall grassstem close together and facing each other. With tails spread they bob up and down, bowing to each other and turning round and round in the most amusing manner, while at the same time they keep up an incessant babel of noise. Suddenly one will fly off to another spot and be followed by the others, when the same performance is repeated. 'The song always sounds as if each of the birds was singing a different part, and for this reason we nicknamed them the "Duet Grass-Warblers." A nest found in January was placed in a bunch of dead grass about 5 feet from the ground. It was domed and composed of blades of dead grass and roots, lined with finer grass and roots. It matched its surroundings so perfectly that it was quite invisible.R. B. W.] 
Cisticola ruforileata Reichenow.

Cisticula rufopileata Reich. Vög. Afr. iii. p. 561 (1905); Sharpe, Ibis, 1908, p. 318 [Cameroon].

a, b. o \&. Mawambi, E. Congo Forest, 2500 ft, 30 th Oct. [Nos. 364.8, 3649. R. B. $T$.

Iris hazel; bill black; feet flesh-colour.

[A pair of Reichenow's Rufous-headed Grass-T'arbler was obtained in a small clearing in the Eastern Congo Forest near Mawambi; the song was rery similar to that of $\left.C . c h u b b i_{0}-R . B . W.\right]$

\section{Cisticola nuchalis Reichenow.}

Cisticola robusta nuchatis Reich. Vög. Afr. iii. p. 555 (1905).

a. o. 30 miles W. of Entebbe, $3500 \mathrm{ft}$., 25 th Nov. [No. 3004. R. B.W.]

b. o . 120 miles W. of Entebbe, 4000 ft., 8th Dec. [No. 2025. G. L.]

c. ס. Fort Portal, $5000 \mathrm{ft.}$, 26th Sept. [No.3616. R. B. W.]

Iris light brown; bill black; feet brown or flesh-colour.

There is a large series of specimens of $C$. nuchalis in Mr. Jackson's collection, which have also been examined.

[This Grass-Warbler was seen near Entebbe and on the plains on the east side of Ruwenzori, where it was not uncommon.-R. B.W.]

\section{Cisticola lugubris (Rüpp.).}

Cisticola lugubris Reich. Vög. Afr. iii. p. 552 (1905).

$a-g . \delta$ et imm. Mokia, S.E. Ruwenzori, $3400 \mathrm{ft} ., 13 \mathrm{th}-20$ th June. [Nos. 1653, d. d.

$1654,1655,1656,1657$. D. C. ; 3472, 3488, R. B.W.]

h-k. $\delta^{3}$. Fort Beni, Semliki Valley, 3000 ft., 22nd-24th July. [Nos. 1739, 1757. U. C. ; 3522. R. B. W.]

Iris pale brown or hazel; bill black; feet pale brown or pale flesh-colour.

Eight of the specimens procured proved to be males; in the other two the sex was not ascertained.

No. 1657, which is almost certainly the young of this species, has the general colour of the upperparts reddish-brown, the feathers of the crown, as well as those of the mantle, being streaked with black; the middle tail-feathers and the margins of the outer pairs reddish-brown; and the flanks and under tail-coverts buff, much brighter than in the adult.

[The Mournful Grass-WVarbler was met with occasionally on the plains at the south end of Ruwenzori, but was a very uncommon bird. A few examples were also seen on the edge of the Eturi Forest near Fort Beni. The song of this bird is totally different 
from that of any other species of Cisticola, and resembles the last half of the song of the Yellow Bunting (Emberiza citrinella).- R. B. WV.]

Cisticola stranget (Fraser).

Cisticola strangei Reich. Vög. Afr. iii. p. 545 (1905).

$a, b$. o. Near Entebbe, 3500 ft., 20th \& 26 th Nov. [Nos. 2. R. E. D.; 1012. D.C.]

c. 8. 100 miles W. of Entebbe, $4000 \mathrm{ft}$, 5th Dec. [No. 2018. G. L.]

$d-k$. o $f$ et o imm. Mokia, S.E. Ruwenzori, $3400 \mathrm{ft}, 26$ th $\& 27$ th April. [Nos. $236,240,257$. R. E. D.; 1439. D. U.; 2094. G. L.; 3276, 327т. R. B.W.]

l-s. of $q$ et o imm. Mokia, S.E. Ruwenzori, $3400 \mathrm{ft} ., 7$ th-23rd May. [Nos. 333, :334, 336. R. E. D.; 1514, 1519, 1548. D. C. ; 3380, 3401.R. B.W.]

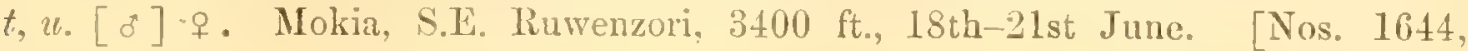
1662. D.C. C.]

Iris light brown or hazel; bill, in the male, blackish, with the lower mandible partly or entirely whitish horn-colour; in the female, light horn-colour; legs varying from flesh-colour to pale brown.

In the present collection the females and immature males differ somewhat from the adult males, and it is with some hesitation that $I$ have referred them to $C$. strangei. 'I'hey have the occiput and nape more or less rufous-brown, the feathers of the crown and upperparts deep black widely margined with pale rufous-brown, aud the flanks and under tail-coverts of a rather bright pale buff. In males of typical $C$. strangei procured in the same locality (S.E. Ruwenzori) and at the same season, the upperparts are altogether darker, the feathers of the crown and back of a browner black marginert with dark greyish-brown, while the flanks and under tail-coverts are pale greyish-buff. It should be noted that the adult males are all in more or less worn plumage, whereas the two immature males and five females are in freshly moulted plumage. 'The bill of the male is larger and blacker than that of the female.

Males. Wing $2 \cdot 7-2 \cdot 75$ inches.

Females. Wing 2.25-2.35 inches.

[Strange's Grass-Warbler was seen near Entebbe and during the march to Ruwenzori. It was numerous on the plains all round the mountains, but was never seen above an altitude of $3400 \mathrm{ft}$. It was one of the most conspicuous species of the genus Cisticala, for it has a loud note, which is often uttered while the bird is hovering about above the grass. $-R . B . W$.]

Scheiricola APiCalis (Cabanis).

Schonicola apicalis Reich. Vög. Afr. iii. p. 577 (1905); Jackson, Ibis, 1906, p. 545 ['Toro].

a. Adult. 40 miles W. of Entebbe, $3500 \mathrm{ft}, 27$ th Nor. $\quad$ [No. 1015. D. C.] rol. XIX.-PART IF. No. 47.--March, 1910. 
b. ơ. Luimi Valley, N.E. Ruwenzori, $6000 \mathrm{ft}$, 1st Oct. [No. 3621. R. B.W.]

c. 万. South Ruwenzori, $3000 \mathrm{ft} ., 20$ th June. [No. 2410. G. L.]

Iris light brown or hazel ; upper mandible blackish, lower pale horn-colour; feet brown or light brown.

'The male bird procured by Mr. Legge on the 20 th of June was breeding, and there is a note on the label stating that the sinews in the legs were like wire. 'Ihis specimen is in very worn plumage and the feathers of the head and throat are in moult.

[The Fan-tailed Reed-Warbler was found all round Ruwenzori below $5000 \mathrm{ft}$., but not in the elephant-grass country. It was not uncommon in the Semliki Valley near Lake Edward.- $-R, B . W$.

\section{Genus Bradypterts.}

The species comprising this genus are of particular interest for the following reasons. They may be naturally divided into two sections:-

I. Possessing 12 tail-feathers, with the shafts moderately stiff and with the vanes normally developed.

B. brachypterus (Vieill.). S.E. \& S. Africa.

B. abyssinicus Blundell \& Lovat. N.E. Africa (S. Abyssinia).

B. sylvaticus Sundev, S. Africa.

B. nyassa Shelley. S.E. Africa (Nyasaland).

B. alfredi Hartl. C. Africa (Lake Albert: Ruwenzori).

B. babreculus (Vieill.). S.E. \& S. Africa.

B. victorini Sundev. S. Africa.

B. cinnamomeus (Küpp.). E. \& C. Africa. Typical examples of this species from the mountains of Shoa, Mount Kenya, and Kikuyu possess 12 tail-feathers, but in a large series of specimens from Ruwenzori only 10 tail-feathers are found, though one example has the abnormal number of 11 (six on the right side and five on the left). It is thus evident that the birds from Ruwenzori, though differing in no way in plumage from specimens from Shoa, show symptoms of becoming gradually differentiated into a distinct form, a point which appears to be of the greatest interest. It will be seen that the specimen of $B$. cimnamomeus from Ruvenzori figured hy Mr. Pycraft to show the pterglography possesses only 10 tail-feathers. (See Appendix, text-figure 14, p. 455.)

II. Possessing 10 pointed tail-feathers, with stiff shafts and with narrow disintegrate webs.

B. barakie Sharpe. C. Africa (Ruwenzori).

B. lopesi Alexander. W. Africa (Fernando Po).

B. camerunensis Alexander. W. Africa (Peak of Cameroon, $7000 \mathrm{ft}$.).

? D. castaneus Reichenow, W. Africa (Bangwa Dist., N. Camcroon). I have not been able to examine an example of this species, which appears to be nearly allied to B. barake.

It was, at first, my intention to separate the species with 10 tail-feathers under a new generic name, on account of the very different character of their tail-feathers, 
which recall those of the genus Stipiturus, but the fact that in the species $B$. cinnamomeus a somewhat intermediate type is found possessing either 10 or 12 tail-feathers, scems to indicate that all the species must be considered co-generic.

Bradypterus barake (Sharpe). (Plate XVI. fig. 3, 30)

Phlexis rufescens Sharpe (nec Sharpe, 1876), Bul1. B. O. C. xiii. p. 9 (1902).

Bradypterus rufescens Reich. Vög. Afr. iii. p. 580 (1905).

Bradypterus barake Starpe, Ibis, 1906, p. $5+6$ [Ruwenzori].

$a, b . o^{+} q$. Mubuku Valley, E. Ruwenzori, 7000-8000 ft., 7 th \& 15th Jan. [Nos. 1152. D. C. ; $3076 . R . B . H$.

$c-f . o^{\circ}$. Mubuku Valley, E. Ruwenzori, 7000-9000 ft., 3rd-26th March. [Nos. 178. R. E. D.; 1281. D. C.; 3192, 3276.R.B.W.]

Iris dark brown or dark hazel; bill blackish, lower mandible mostly light horn-colour or greyish; feet brown, light brown, or pale olive-green.

The birds are all fully adult and differ in no way from the type-specimen.

'This species appears to be very closely allied to B. castaneus Reich. from Cameroon, but the latter is described as having the throat white.

[Baraka's Reed-Warbler was found on Ruwenzori from an elevation of 6500 up to $8500 \mathrm{ft}$., and inhabited the darkest parts of the forest-zone, especially where there was dense undergrowth. Like Bradypterus cinnamomeus, this bird always appeared wet and draggled from creeping about among the dripping undergrowth. It seemed very rarely to use its wings. $-R, B . W$.

Bradypterus Cixtamoneus (Rüpp.).

Bradypterus cinnamomeus Reich. Vög. Afr. iii. p. 581 (1905); Jackson, Ibis, 1906, p. 5.15 [Ruwenzori].

Bradypterus rufoflavidus Reich. \& Neumamn; Reich. Vög. Afr. iii. p. 582 (1905) [immaturc]. $a-c$. o to vix ad. Mubuku Valley, E. Ruwenzori, 7000-9000 ft., 8th-23rd Jan. [Nos. 1117, 1157, 1183. D. C.]

d-h. o ㅇ. Mubuku Valley, E. Ruwenzori, 7000-10,000 ft., 10th-28th Feb. [Nos.

166. R. E. D.; 1273. D. C.; 3158, 3170,3172.R. B. H.]

i. Imm. Mubuku Valley, E. Ruwenzori, $9000 \mathrm{ft}$, 10th March. [No. 1315. D. C.] k-0. o ․ Butagu Valley, W. Ruwenzori, $7000 \mathrm{ft}$., 1st August. [Nos. 499. R. E. D.;

1763, 1764.D.C.; 3529, 3533.R. B.W.]

Iris brown or hazel ; bill blackish, lower mandible lighter; feet brown or light brown. An immature bird [No. 1315] shot by Mr. Carruthers differs from the adult in having the top of head and upperparts, except the wings and tail, olive-bromn, with scarcely a trace of rufous. The superciliary stripes, sides of the face, chin, and 
throat, as well as the middle of the breast and belly, of a pale soiled yellowish colour. The pectoral band, which is interrupted by a yellow patch in the middle, as well as the sides and flanks, dark tawny brown. Wing $2 \cdot 25$ inches; tail 2.4 . Iris dark hazel; bill black, yellow at the base of the lower mandible; feet very light brown.

Remarks on some points in the anatomy of this species by $\mathrm{Mr}$. W. P. Pycraft will be found in the Appendix to this paper, p. 454.

[Rüppell's Reed-Warbler was found on Ruwenzori from an elevation of 6500 to [:,000 ft. It frequented the undergrowth, especially where it was densest, and was particularly numerous at about $10,000 \mathrm{ft}$, where the bottoms of the valleys were swampy and full of low rank vegetation. Among this it was always to be found creeping about and constantly uttering a single note, almost exactly like that of the Hedge-Sparrow. Both B. cinnamomeus and B. baraka have also a loud short song of stridulous notes, which they often utter with startling suddenness. One cannot fail to remark the striking resemblance of the song of these two birds to that of Cetti's Warbler (Cettia cetti), and their habits are exactly the same. Another marked point of resemblance is the extraordinary development of the leg-muscles and the tough wiry sinews-in fact, the three species are so much alike that one almost wonders they should have been separated generically.-R. B. W.]

Bradypterus alFredi Hartl. (Plate XVI. fig. 1, ‥)

Bradypterus alfredi Reich. Vög. Afr. iii. p. 579 (1905).

a. ․ Mubuku Valley, E. Ruwenzori, $5000 \mathrm{ft}$, 5th April. [No. 2276. G. L.]

Iris dark brown; upper mandible black, lower slate-colour; feet brown.

I have compared this bird with the type-specimen in the Tring Museum, which was obtained by Emin at Njangabo, in Ndussuma, to the west of Lake Albert, and find that they are quite similar. 'This species is new to the British Museum.

[A single specimen of this rare Reed-Warbler was obtained by Mr. Gerald Legge on the east side of Ruwenzori among the grass and dense vegetation below the forest-line at $5000 \mathrm{ft}$. It had the great development of leg-muscles and wiry sinews noticed in other species of the genus Bradypterus and in Schoenicola apicalis. $-R . B . W$.

Calanocichla nilotica Neumamn.

Calamocichla ansorgei nilotica Neumann, Nor. Zool, xv. p. 246 (1908).

a. Immature [? o ]. Mubuku Valley, E. Ruwenzori, $5000 \mathrm{ft}, 27$ th March. [No. 2951. G.L.]

b. ơ imm. Fort Beni, Semliki Valley, $3000 \mathrm{ft}, 24$ th July. [No. 3521. R. B. W.]

Iris dark brown; bill brown; feet dark grey or slate-blue.

Professor Neumann, who has recently devoted much time and attention to the study of this difficult group of birds, has referred both specimens in the present collection to a 
new subspecies which he has called Calamocichla ansorgei nilotica. As pointed out by Professor Neumann, this form may be distinguished from C.rufescens Sharpe \& Bouvier by the much larger hind claw, 11-12 $\mathrm{mm}$. in length.

[This Reed-Warbler occurs near Entebbe and all round Ruwenzori below $5000 \mathrm{ft}$. It is seldom seen, owing to its habit of keeping to the dense patches of elephant-grass and reeds, but its harsh raucous notes never fail to betray its presence. $-R . l l . W$.

SyLVIA ATRICAPILla (Linn.).

Sylvia atricapilla Reich. Vög. Afr. iii. p. 650 (1905).

$a, b$. o . Mubuku Valley, E. Ruwenzori, $7000 \mathrm{ft.,} 9$ th \& 27 th Jan. [Nos. 82. R. E. D.; 2118. G. L.]

c. f. MLubuku Valley, E. Ruwenzori, $6500 \mathrm{ft} ., 11$ th Feb. [No. 3161. R. B. H.]

d. o . " $\quad " \quad$ " $7000 \mathrm{ft} .$, 16th March. [No. 3225. R. B. W.]

[The Blackcap was met with only on E. Ruwenzori at an elevation of from $6000-7000 \mathrm{ft}$. It had the iris hazel or dark brown; the bill blackish-brown, dark brown, or grey; and the feet grey, olive-grey, or bluish-grey.- $R . B . W$.

SyLViA hoRTExsis Linn.

Sylvia simplex Lath.; Reich. Vög. Afr. iii. p. 619 (1905).

a. o. 130 miles W. of Entebbe, $4200 \mathrm{ft} .9$ th Dec. [No. 1052, D. C.]

b. o. Mubuku Valley, E. Ruwenzori, $5000 \mathrm{ft}, 16$ th March. [No. 205. R. E. D.]

[The Garden-Warbler was seldom seen. The iris is dark brown or dark hazel; the bill black, lighter on the lower mandible; and the feet slate-colour or grey. $-R . B . W$.]

Phylloscopus eVerisinani (Bonap.).

Phylloscopus trochilus eversmanni Hartert, Vög. Pal. Faun. pt. iv. p. 509 (1907).

a. o . Mubuku Valley, E. Ruwenzori, $7000 \mathrm{ft}$. , 8th Feb. [No. 3150. R. B. W.]

'This appears to be an adult male of Eversmann's Willow-Warbler.

Wing $2 \cdot 9$ inches. Both the remiges and rectrices are in moult.

P'HYlloscopus trochilus (Linn.).

Phylloscopus trochilus Reich. Vög. Afr. iii. p. 644 (1905).

a. Immature. Entebbe, $3500 \mathrm{ft} ., 21 \mathrm{st}$ Nov. [No.6. R. E. D.]

b. + Mubuku Valley, E. Ruwenzori, $5000 \mathrm{ft}$., 16th March. [No. 207. R. E. D.]

The female Willow-Warbler, shot in March, is in full moult.

Apalis denti Grant. (Plate XIV. fig. 3, ․)

Apalis denti Grant, Bull, B. O. C. xix. p. 86 (1907).

a. ․ Mpanga Forest, Fort Portal, $5000 \mathrm{ft} ., 16 \mathrm{th}$ Sept. [No. 521. R. E. U. Type of the species.] 
This species is most nearly allied to $A$. rufogularis (Fraser), but is distinguished by liaving a shorter bill, with the under mandible entirely black, the throat and chest of in paler and brighter brick-red, and the breast and belly pure white, without any trace of olive.

Iris hazel; bill black; feet flesh-colour.

'lotal length 4.3 inches; wing 1.9 ; tail 1.85 ; tarsus 0.72 .

[ $\mathrm{A}$ single specimen of this new species was shot by Mr. R. E. Dent in the top of a tall tree in the Mpanga Forest. It was the only specimen seen.- R. B. W.]

Apalis AFFinis Grant. (Plate XIV. fig. 2, 0* .)

Apalis affinis Grant, Bull. B.O.C. xvi. p. 116 (1906).

Apalis porphyrolema Jackson (nec Reich. \& Neumann), Ibis, 1906, p. 546 [Ruwenzori].

a. b. o f. Mubuku Valley, E. Ruwenzori, $6000 \mathrm{ft} ., 11$ th January. [Nos. 88, 89. Ii. E. D. Types of the species.]

This Alpine species is most nearly allied to A. porphyrolama Reich. \& Neum., but has the throat-patch of a much darker chestnut-colour.

Iris light hazel; bill black; feet light brown.

Total length about 4.5 inches; culmen 0.5 ; wing 2.0 ; tail 2.1 ; tarsus 0.7 .

[During the first week of our stay on Ruwenzori Mr. R. E. Dent one morning shot four examples of this little bird out of a flock of six or eight individuals. 'Ihey were seen in the top of a tall tree in the forest at $6000 \mathrm{ft}$. 'Two of them were much knocked about by the shot or splinters of wood, and, thinking that we were certain to procure many more specimens during our stay, only a pair was preserved. Unfortunately these proved to be the only ones met with by the Expedition. It is remarkable that the two new species of the genus Apalis should have been obtained by Mr. Dent under almost exactly similar circumstances.

A. affinis must be a very rare bird, and probably $A$. denti is equally so. $-R . B . W$.]

Apatis Canicers (Cassin).

Eremomela caniceps Reich. Vög. Afr. iii. p. 638 (1905).

r. 3. Fort Beni, Semliki Valley, $3000 \mathrm{ft}, 22 \mathrm{nd}$ July. [No.3511. R. B. W.]

Iris light hazel; bill black; feet dark flesh-colour.

The characters of the genus Apatis require revision, for the present species certainly belongs to this genus and not to Eremomela. 'The tail is longer and graduated as in A. thoracica (Shaw \& Nodd.) (the type of Apalis), and not short and squareended as in E. flaviventris (Burch.) (the type of Eremomela).

[A single specimen was obtained on the edge of the Eturi Forest, at Fort Beni. It was breeding at the end of July. $-R . M . W$. 
Apalis JaCksoni Sharpe.

Apalis jacksoni Reich. Vög. Afr. iii. p. 608 (1905).

a, b. o 우. Mpanga Forest, Fort Portal, $5000 \mathrm{ft}$., 18th \& 19 th Sept. [Nos. 358\%, 3583. R. B.W.]

Iris dark brown; bill black; feet light brown.

The only example in the British Museum of this beautiful little Bush-TVarbler is the type-specimen, which was procured by Mr. Jackson on Mount Elgon. His collector subsequently procured an adult male and two females at Kibiran, T'oro.

[A few examples of Jackson's Bush-Warbler were met with in the Mpanga Forest, east of Ruwenzori. They were seen only in the tree-tops. $-R . B . W$.]

Apalis binotata Reichenow.

Apalis binotata Reich. J.f. O. 1896, p. 41, pl. v. [Cameroon: ठ] ] id. Vög. Afr. iii. p. 60s (1905); Sharpe, Ibis, 1908, p. 320 [R. Ja, Cameroon].

a. ․ Mpanga Forest, Fort Portal, $5000 \mathrm{ft} ., 15$ th Sept. $\quad[$ No. 3567. R. B. IV.]

Iris light chestnut; bill black; feet light brown.

As pointed out by Dr. Sharpe, the sexes in this species differ slightly from each other in plumage; the bird described and figured by Dr. Reichenow with a white patch on either side of the throat being the male, while the female has a broad band of white on either side extending from the chin to the base of the throat.

The present specimen differs slightly from typical female specimens from Cameroon in having the white streak on each side of the throat reduced in width and the bill distinctly shorter $(.05$ inch as compared with $\cdot 06)$.

Female specimens from Toro in the Jackson Collection are indistinguishable from Cameroon birds.

[This species of Bush-Warbler was rery plentiful in the Mpanga Forest.- $R . B . W$. ]

Apalis personata Sharpe.

Apalis personata Reich. Vög. Afr. iii. p. 608 (1905); Jackson, Ibis, 1906, p. 547 [Ruwenzori]. $a-f$. of of et $o^{*} \mathrm{imm}$. Mubuku Valley, E. Ruwenzori, 6000-9000 ft., 6th-25th Jan. [Nos. 70, 106, 126.R.E. D.; 1112, 1121, 1143. D.C.]

g. 3. Mubuku Valley, T. Ruwenzori, $6000 \mathrm{ft}$., 6th Feb. [No. 121S. D. C.]

$h-q$. of ot o imm. Mubuku Valley, E. Ruwenzori, 6000-9000 ft., 8th-22ud d. $1303,1316,1319,1367,1395,1405$. D. C. ; 3194, 3226, 3237. R. B. W. March. [Nos. 1303, 1316, 13in, 1367 , black; feet brown, light brown, or flesh-coloured.
Tris hazel or light brown; bill blat

Three males (Nos. 106, 3226, 3237) have the hinder part of the crown mixed with olive-coloured feathers like those of the back. 'This appears to be a sign of immaturity; 
but in other respects they resemble the adult, which has the entire crown sooty black. One male (No. 1112), apparently an old bird, has the black feathers of the crown separated from the olive-coloured mantle by a narrow slate-grey collar. Another male (No. 1143) has olive-green patches, instead of yellow, on either side of the black chest; this also is probably a character due to age, as the bird shows traces of the grey nuchal collar referred to in specimen No. 1112.

[The Masked Bush-Warbler was met with on Ruwenzori up to $9000 \mathrm{ft}$. and was numerous in the forest-zone, almost always frequenting the tree-tops, though it was also occasionally to be found among the undergrowth.- $R . B . W$.

\section{Apalis Ruwexzoril Jackson. (Plate XIV. fig. 4, ơ.)}

Apalis ruwenzorii Reich. Vög. Afr. iii. p. 606 (1905) ; Jackson, Ibis, 1906, p. 547 [Ruwenzori].

$a-d$. o . Mukubu Valley, E. Ruwenzori, 6000-8000 ft., 13th-18th Jan. [Nos. 1147, 1155. D. C. ; 2095. G. L. ; 3105.R. B.W.]

e. o* Mubuku Valley, E. Rumenzori, $6000 \mathrm{ft}$, 11th Feb. [No. 1226. D. C.]

$f-q . \delta^{\circ}+., \quad, \quad$, $\quad$ 6000-9000 ft., 6th-25th March. [Nos. 199. I. E. D. ; 12 $96,1297,1298,1318,1374$. D. C.; 2242, 2248. G. L. ; 3196, 3197 , 3227. R. B. W.]

r. Adult. Butagu Valley, W. Ruwenzori, 7000 ft., 1st Aug. [No. 3528. R. B. W.]

Iris hazel or light brown; bill black; feet brown or flesh-colonr.

[The Ruwenzori Bush-Warbler was met with from $6500 \mathrm{ft}$. up to $10,000 \mathrm{ft}$., but it was rarely seen above $8500 \mathrm{ft}$. It was numerous in the forest-zone and lower margin of the bamboos, and was always to be found skulking about among the dense undergrowth or in some tangled mass of creepers hanging from the lower branches of a tree. This species was never seen in the tree-tops, while the two other members of the genus (A. personata Sharpe and $A$. affinis Grant) found on Ruwenzori frequent the tree-tops almost entirely. $-R . R . W$.

A Palis Pulchella (Cretzschm.).

Phyllolais hildegarda Sharpe; Grant \& Reid, Ibis, 1901, p. 649 [S. Abyssinia].

Phyllolais pulchella Grant, Ibis, 1902, p. 419 [White Nile]; Jackson, Ibis, 1906, p. 548 [T'oro].

Apalis hildegardæe Reich. Vüg. Afr. iii. p. 603 (1905).

Apalis pulchella Reich. 1. c. p. 610 .

a-e. of ㅇ. Mokia, S.E. Ruwenzori, $3400 \mathrm{ft} ., 26$ th-30th April. [Nos. 1444, 1447, 1458. D. C. ; 3283, 3298. R. B.W.] 
f-u. o q. Mokia, S. E. Ruwenzori, 3400 ft., 5th-23rd May. [Nos. 261, 320 R. E. D. : 1516, $1549,1580$. D.C.; $3325,3333,3367,3368,3372,3373,3377,3378$, $3379,3400 . R . B . W$.

Iris hazel or light brown; bill brown, light brown, or flesh-colour; feet pale brown or flesh-colour.

'The fine series of this species in the present collection makes it clear that $P$. hildegarda Sharpe must be regarded as a synonym; the supposed different colour of the bill, which I at one time regarded as a distinctive character, being evidently of no importance.

[The Beautiful Bush-Warbler was plentiful all around the south end of Ruwenzori, both on the plains at the foot of the mountains and in the Semliki Valley. Its favourite haunt was the tops of the smaller acacia-trees. $-R . B . W$.]

EMINia zeipid Hartlaub.

Eminia lepida Reich. Vög. Afr. iii,p. 613 (1905); Jackson, Ibis, 1906, p. 54 [Toro].

a, b. o ․․ Mubuku Valley, E. Ruwenzori, 6000 and $7000 \mathrm{ft}$. , 5th \& 9 th Jan. $[$ Yos. 66, S0. R. E. D.]

c, d. o f. MLbuku Valley, E. Ruwenzori, 6000 ft., Sth Feb. [Nos. 3151, 3152. li. li. II.

e. ․ Mubuku Valley, E. Ruwenzori, $7000 \mathrm{ft} .$, Sth April. [No. 3270. R. B. W.]

$f-p$. of et $q \mathrm{imm}$. Molin, S.E. Ruwenzori, 3rd-26th May. [Nos. 346, 35\%). R. E. D. ; 1538, 1573, 1574, 1582, 1601, 1614. D. C. ; 2367, 2401. G. L. ; $331 \%$ R. B. W.]

q. उ. Fort Beni, Semliki Valley, $3000 \mathrm{ft.}$, 18th July. [No. 3503. R. B. IV.]

Adult. Iris hazel, reddish-brown, or chestnut; bill black; feet Jight brown on fleshcolour.

Immature. Differs from the adult only in having the chestnut on the throat and under wing-coverts paler. Iris grey; bill black; feet pale yellow.

[A few examples of Emin's Bush-Warbler were found on Ruwenzori up to $7000 \mathrm{ft}$., but they were uncommon. They were plentiful on the plains below the mountains. frequenting the more dense vegetation along the banks of streams. 'Two nests were found, one at the beginning of May and the other at the end of July, but both contained young birds. One nest was suspended from a single creeper hanging over a stream, under a great mass of tangled vegetation and creepers forming quite a tumnel. The other was in a very similar situation, but was placed among the creepers and not suspended. Both nests were partially domed and composed of fine roots and moss. 'This bird has a short but very loud song composed of flute-like notes.- $R . B . W$. vol. xix.-PART IV. No. 48.-March, 1910. 
Sylviella barake Sharpe. (Plate XIX. fig. 6, egg.)

Sylviella barake Sharpe, Bull. B. O. C. vii. p. 6 (1897) [Entebbe]; Grant, Ibis, 1900, p. 156. Sylvietta virens Reich. Vög. Afr. iii. p. 631 (1905) [part.].

a-d. o . Fort Beni, Semliki Valley, $3000 \mathrm{ft} ., 22 \mathrm{nd-24th} \mathrm{July.} \mathrm{[Nos.} \mathrm{1747.} \mathrm{D.} \mathrm{C.;}$ $3510,3517,3523 . R . B . W]$

Iris hazel or light brown; bill dusky horn-colour; feet flesh-colour or brown.

This species can be distinguished from fully adult examples of the very closely allied S. virens (Cassin) by having the superciliary stripe, as well as the chin and throat, dull whitish instead of rufous, the chest less rufous, and the upper breast greyer. Less mature examples of the two forms appear to be indistinguishable. The West African So virens is a rather more brightly coloured bird on the throat and chest.

The specimens in the present collection are no doubt fully adult, and No. 3510 is marked "breeding" by Mr. Woosnam.

The egg figured forms part of Mr. F. J. Jackson's collection.

[A few examples of Baraka's Crombec were seen in the Etuxi Forest between Fort Beni and Irumu.- $R . B . W$.

\section{Srltielia toroensis Jackson.}

Sylvietta toroensis Reich. Vög. Afr. iii. p. 632 (1905).

Sylviella toroensis Jackson, Ibis, 1906, 1. 518 [Kibera R.].

$a-c$. $\delta^{*}$ o et o imm. Mpanga Forest, Fort Portal, $5000 \mathrm{ft}, 14$ th \& 21st Sept. [Nos. 3560, 3595, 3602. R. B.W.]

Adult. Iris hazel; bill horn-colour; feet brown.

Immature. Differs from the adult in having the upperparts strongly washed with dark olive, the lores greyish, the sides of the throat pale yellowish, and the chest grey washed with yellowish in the middle. Iris olive-brown; bill horn-colour; feet light greenish-brown.

[A few examples of the Toro Crombec were seen in the Mpanga Forest, E. of Ruwenzori. $-R . B . W$.

\section{Srlvielda leucophris Sharpe.}

Sylvietia leucophrys Reich. Vög. Afr. iii.p. 631 (1905).

Sylviella leucophrys Jackson, Ibis, 1906, p. 549 [Ruwenzori]

a. Adult. Mpanga Forest, Fort Portal, 5000 ft., 19th Sept. [No.542. R. E. D.]

$b-f$. o ㅇ. Mubuku Valley, E. Ruwenzori, 7000-8500 ft., 13th-16th Jan. [Nos. 94.R.E. D.; 1134, 1140, 1141, 1156.D.C.] 
g-k. of f et imm. Mubuku Valley, E. Ruwenzori, 6000-7000 ft., 3rd-22nd Feb. d.

[Nos. 146.R. E. D.; 1214, 1224. D.C.;2164.G.L.]

l-q. ơ ㅇ. Mubuku Valley, E. Ruwenzori, 6500-8000 ft., 3rd-24th March. [Nos. 179, 192, 193. R. E. D. ; 3242, 3243, 3260.R. B. $\Pi^{*}$.

r. Adult. Butagu Valley, W. Ruwenzori, 7000 ft., 1st Aug. [No. 2445. G. L.]

Iris hazel, dark chestnut, or brown; bill and feet brown or flesh-colour.

One adult female (No. 1140) differs from the rest of the series of specimens in having the upperparts more olive and less brownish, especially on the rump.

An immature bird (No. 146) differs chiefly from the adult in having the eyebrowstripe less developed and the breast smoky grey, the middle of the throat being suffused with the same colour.

['The White-eyebrowed Crombec was found on Ruwenzori up to $5500 \mathrm{ft}$, frequenting the dense undergrowth both in the forest-zone and below it. It was also found in the Mpanga Forest. $-R . B . W$.

\section{Sylviella CaRnaPi Reichenow?}

Sylviella brachyura Grant, Ibis, 1900, p. 155 [part., Equatorial Africa]; id. Ibis, 1907, p. 593. Syluietla carnapi Reich. Vög. Afr. iii. p. 628 (1905).

a, b. +. Mokia, S.E. Ruwenzori, $3400 \mathrm{ft}, 26$ th \& 29 th April. [Nos. 1435, 1456. I. C.]

$c-k$. o ㅇ․ Mokia, S.E. Ruwenzori, $3400 \mathrm{ft.g}$ 1st-24th May. [Nos. 1509. D. C.; d.

2375. G. L.; 3300, 3352, 3389, 3402, 3407, 340s. R. B. IV.]

l. o. Mokia, S.E. Ruwenzori, $3400 \mathrm{ft}$, 7th June. [No. 438. R. E. D.]

This form ranges from the Bahr-el-Zeraf and Bahr-el-Jebel to Lake Edward. It appears to be the same as $S$. carnapi Reich. from Cameroon, but I have no birds from that locality for comparison. Dr. Reichenow's description, however, seems to agree with the birds from Mokia. They may be described as follows:-

Adult male and female. Most nearly allied to S. brachyurce Lafr., but differ in having the chin, throat, breast, sicles, and flanks of a much richer rufous-buff, and the bill distinctly shorter. The upper surface seems to be of much the same brownishgrey colour in both forms.

8*. Wing 2:25-2.35 inches.

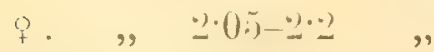

Iris hazel, chestnut, or light brown; bill dark brownish horn-colour; feet fleshcolour or very pale brown.

With a large series of specimens of both forms the difference between the two is at once apparent. 
The above-mentioned specimens are not so richly coloured on the underparts as in S. olvive Alexander [cf. Bull. B. O. C. xxiii. p. 16 (1908)].

[This small species of Crombec was not uncommon in the acacia-country on the plains around the south end of Ruwenzori and in the Semliki Valley near Lake Edward. It seemed to frequent the acacia-trees almost exclusively, $-R, B, W$.

Srltielta dentr Grant. (Plate XIII. fig. 3, o .)

Sylviella denti Grant, Bull. B. O. C. xix. p. 25 (1906).

Sylviella batesi Sharpe, Ibis, 1908, p. 319 [R. Ja, Cameroon].

a. đ. 10 miles N.W. of Fort Beni, Semliki Valley, $3000 \mathrm{ft.,} 10$ th Aug. [No. 3539. R. B.W. Type of the species.]

This species is most nearly allied to S. Aqviventiv Sharpe, from which it differs chicfly in being somewhat larger; in having both mandibles entirely black; the back dark olive without any brownish tinge; the feathers surrounding the eye and on the cheeks whitish with black tips, giving these parts a distinctly spotted appearance; the chest and breast dull olive-green and the belly and rest of the underparts pale yellow. Iris hazel; bill black; feet reddish-brown. 'Total length about 3 inches; wing 2; tail 0.75 ; tarsus 0.66 .

'Ihis species ranges to the Southern Cameroon, whence it has been describer as S. batesi.

[The single example of Dent's Crombec obtained near Fort Beni, on the edge of the Eturi Forest, was the only one seen.- $R . B . W$.]

Camaroptera superciliaris (Fraser).

Camaroptera superciliaris Reich. Vög. Afr. iii. p. 621 (1905).

a. o. Nr. Mawambi, E. Congo Forest, 20th Oct. [No.3637. R. B.W.]

Iris dark brown; bill black; feet brown.

The discovery of this species in the Eastern Congo Forest greatly increases its known range. It was known to occur in West Africa from the Gold Coast to the Kamma River.

[This example of the Yellow-browed Bush-Warbler was the only one met with.li. B. W.]

Camaroptera griseoviridis (v. Müll.). (Plate XiX. fig. 10, egg.)

Camaroptera chrysocnemis Licht.; Grant \& Reid, Ibis, 1901, p. 648.

Camaroptera griseoviridlis Reich. Vög. Afr. iii. p. 616 (1905); Jackson, Ibis, 1906, p. 549 [Toro].

a-c. o . Mubuku Valley, E. Rumenzori, $5500 \mathrm{ft.}, 21$ st Feb. [Nos. 1249, 1250, 1251. D.C.] 
d, e. o . Mokia, S.F. Ruwenzori, 3400 ft., 26th April. [Nos. 3279, 3285. R. B. W.]

$f-x$. of \& et $\delta$ imm. Mokia, S.E. Ruwenzori, $3400 \mathrm{ft}$., 3rd-31st May. [Nos. 287,

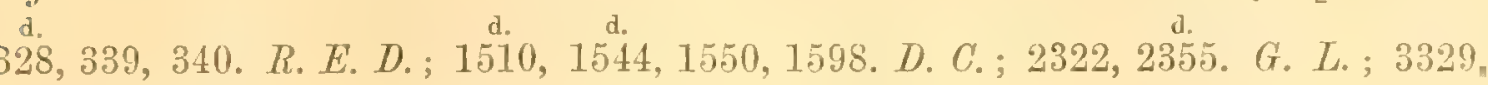
ग28, $339,340$. R. 3330, 3331, 3349, 3382, 3383, 3388, 3435. R. B. W.]

y,z. P. Mokia, S.E. Ruwenzori, $3400 \mathrm{ft}$, 1st \& 27 th June. [Nos. 408. R. E. L.; 1699. L.C.]

Iris hazel; bill black; feet flesh-colour or light brown.

'The egg figured forms part of Mr. F. J. Jackson's collection.

[The Grey-breasted Bush-IVarbler was very numerous on the plains all round the mountains, but was never seen on Ruwenzori above $5500 \mathrm{ft}$. It was met with throughout the journey across the Congo Forest, and was seen as far down the Congo as Coquilhatville. Its habits are very similar to those of the Common Wren, and its note, which is continually uttered, is almost identical with that of the Common Stonechat. $-R . B . W$.

\section{STIPHRORNiS XANTHOGASTER Sharpe.}

Stiphrornis xanthogaster Sharpe, Ibis, 1905, p. 476, pl. ix. [Cameroon]; Reich. Vög. Afr. iii. p. 621 (1905); Sharpe, Ibis, 1908, p. 3.25.

a. o (? imm.). Nr. Mawambi, E. Congo Forest, $3000 \mathrm{ft}, 24$ th Oct. [No. 3642. R. B. $\left[H^{Y}.\right]$

Iris dark brown; bill black; feet grey.

An immature male assuming the adult plumage(?) has the upperparts strongly washed with olive and the wings and tail in moult, the former being nearly complete, while in the latter the feathers are all less than an inch in length. 'The underparts resemble those of the adult male, but many of the feathers of the chin and throat are in moult.

'This species was recently described by Dr. Sharpe from specimens procured by Mr. G. L. Bates in Southern Cameroon.

[A single specimen of this beautiful Orange-breasted Bush-Warbler, the only one seen, was obtained in the Congo Forest near Mawambi. It was hopping about among the undergrowth. $-R . B . W$.]

\section{Hrlia prasina (Cass.).}

Hylia prasina Reich. Vög. Afr. iii. p. 622 (1905); Grant, Ibis, 1908, p. 292.

a. ․ Mpanga Forest, Fort Portal, 5000 ft., 16th Sept. [No.3569. R. B. II.]

b. + Fort Beni, Semliki Valley, $3000 \mathrm{ft}$., 9 th Aug. [No. 1768. D.C.] 
c, d. o . Nr. Mawambi, E. Congo Forest, 3000 ft., 18th \& 20th Oct. [Nos. 573. T. E. D.; 3635. R. B.W.]

Iris brown, dark hazel, or chocolate; bill dark brown or black : feet olive-green.

A male (No.57:) and a female (No. 1768) are marked "breeding."

Some important notes on this species will be found in my paper published on Mr. Carruthers's collection from the Upper Congo ('Ibis,' 1908, pp. 292-293).

['This 'Tree-Warbler was met with in the Congo Forest throughout the journey; also in the Mpanga Forest to the east of Ruwenzori.- R. B. W.

Prinia mistacea Rüpp.

Prinia mystacea Reich. Vög. Afr. iii. p. 590 (1905).

a-c. o ․ Near Entebbe, $3500 \mathrm{ft}, 20 \mathrm{th}-27$ th Nor. [Nos. 3. R. E. D.; 1006, 1114. D.C.]

$d-g$. ㅇ et $\delta^{3} \mathrm{imm}$. 80-120 miles W. of Entebbe, 3500-4000 ft., 2nd-8th Dec. [Nos. 21, 23. R. E. D. ; 1027. D. C.; 3039.R.R.W.]

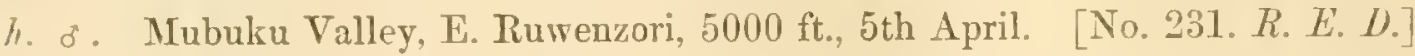

i-n. o f. Mokia, S.E. Ruwenzori, 3400 ft., 26th-29th April. [Nos. 245, 252.

R. E. D. ; 1442. D.C.; 3278, 3295. R.B.W.]

o-v. $\sigma^{\circ}$ ㅇ. Mokia, S. E. Ruwenzori, $3400 \mathrm{ft}$, Sth-31st May. [Nos. 299, 356, 401. R. E. D.; 3337, $3341,3376,3414,3415 . R . R . W$.

$w, x . \sigma^{*}$. Fort Beni, Semliki Valley, 23rd July. [Nos. 2425, 2426. G. L.]

Iris hazel; bill brown or black; legs flesh-colour or brown.

A quite young bird has the brown colour of the upperparts washed with rufous, and the chin, throat, and chest pale yellowish-white.

[The Tawny-flanked TVren-Warbler was numerous on the plains all around Ruwenzori, but was never seen on the mountains above $5000 \mathrm{ft}$. It seemed to frequent the acacia-trees more than the grass, and when disturbed always flew to the top of a neighbouring acacia-tree.- $R . B . I V$.

Btirnesia melanops Reichenow \& Neumann.

Burnesia melanops Reich. \& Neum. Orn. Monats. iii. p. 75 (1895).

Prinia melanops Reich. Vög. Afr. iii. p. 597 (1905).

a, b. o 오. Mpanga Forest, Fort Portal, 5000 ft., 16 th Sept. [Nos. 3570, 3571.

i. Ii. H.]

c. ․ Mubulku Valley, E. Rurenzori, $6000 \mathrm{ft} ., 20$ th Jan. [No. 1171. D. C.]

$d, e . d . \quad, \quad 5500 \mathrm{ft} .$, Tth March. [Nos, 191, 192.

li. F. D. D.] 
Iris yellow or light hazel; bill black; feet black or greyish-brown.

[A few examples of the Black-faced Wren-Warbler were seen in the Mubuku Valley below the forest-line, but the species was decidedly rare there: at the nortla end of the range it was numerous among the rough country and straggling forest at $6500 \mathrm{ft}$. It was also plentiful in the Mpanga Forest, E. of Ruwenzori, frequenting the thick undergrowth, among which it might always be heard, but was very seldom seen. - R. R. W.]

\section{Burnesia bairdi (Cass.).}

Prinia bairdi Reich. Vög. Afr. iii. p. $59 \%$ (1905).

$a, b$. o o. 20 miles N.W. of Fort Beni, Semliki Valley, $3000 \mathrm{ft}$., 11th Aug. [Nos. 3542, 3543. R. B. W.]

The birds from Fort Beni agree perfectly with typical specimens from Cameroon.

[Baird's Wren-Warbler was plentiful in the Eturi Forest between Fort Beni and Irumu, but it was not seen further west than Mawambi. It was usually found among the dense vegetation on the edge of the forest around the native-clearings and villages. $-R . B . W$.

Burnesia Reichesowi Hartl.

Prinia reichenowi Reich. Vög. Afr. iii. p. 595 (1905).

Burnesia reichenowi Jackson, Ibis, 1906, p. 549 [Toro].

a-c. o. Mipanga Forest, Fort Portal, $5000 \mathrm{ft}$, 14th-24th Sept. [Nos. 3559, 3610 , 3rill. R. B. IH.]

d. o. Mubuku Valley, E. Ruwenzori, $6000 \mathrm{ft.,} \mathrm{23rd} \mathrm{Jan.} \mathrm{[No.} \mathrm{1184.} \mathrm{D.} \mathrm{C.]}$

e,f. ㅇ. $, \quad, \quad 5500$ and $6500 \mathrm{ft}$. 4th \& 19th March.

[Nos. 183. R. E. D.; 3241.R. B. W . ]

g-k. o ㅇ․ Mokia, S.E. Ruwenzori, $3400 \mathrm{ft}, 10$ th-19th May. [Nos. 1541, 1542. D.C.; 2368,2372 . G. L. .

l, m. ․ Fort Beni, Semliki Valley, 3000 ft., 23ird July. [Nos. 1743, 1744. D. C.]

Iris bright chestnut; bill black; feet reddish-brown.

[Reichenow's Wren-Warbler was found on Ruwenzori up to $6500 \mathrm{ft}$., the lower limit of the forest-zone, and inhabited the more open cultivated ground. It was also found on the plains all around the mountains, and at Fort Beni on the edge of the Eturi Forest. I have often heard this little bird singing beautifully, late in the evening and in the early morning. $-R . B . W$.] 


\section{Family TURDID $\mathbb{E}$.}

Geocichla piagGias (Bouv.). (Plate XIX. fig. 3, egg.)

Geocichla piaggia Reich. Vög. A fr. iii. p. 683 (1905); Jackson, Ibis, 1906, p. 543 [Ruwenzori].

a, b. o ㅇ․ Mubuliu Valley, E. Ruwenzori, $8000 \mathrm{ft.,}$ 11th \& 13th Jan. [Nos. 1132, 1149. D. C.]

c, d. ㅇ imm. Mubuku Valley, E. Ruwenzori, 6000 and $8000 \mathrm{ft}$., Ist \& 24th Feb. [Nos. 136.R.E. D.; 1264.D.C.]

e. ․ . Mubuku Valley, E. Ruwenzori, $9000 \mathrm{ft}$, 10th March. [No. 1311. D. C.]

Iris dark hazel; bill black; feet light brown.

The immature bird has the upperparts browner than in the adult, the feathers of the head and back streaked along the shaft with pale rufous, and there is a $V$-shaped black band at the extremity of the feathers on the cheeks, sides of the throat, chest, breast, and flanks.

'Two eggs are of a regular oval shne and somewhat glossy. 'The ground-colour is pale greenish-blue, marked all over with small blotches and spots of chestnut and purplish-grey. They measure respectively $1.1 \times \cdot 78$ and $1.05 \times \cdot 76$ inch.

Both eggs are considerably damaged, the female having been shot on the nest.

[The Central-African Ground-Ihrush was met with on Ruwenzori at altitudes of from 5000 to $9000 \mathrm{ft}$. It appeared chiefly to frequent the upper parts of the forestzone, but it was a rare bird and seldom seen. A nest, found on the 10th of March at an altitude of $8600 \mathrm{ft}$., was placed in the fork of a small tree about 5 feet from the ground, and resembled that of the Blackbird. It contained two eggrs.-R. B. W.]

Terdus abyssinicus Gmel.

Turdus abyssinicus Reich. Vög. Afr. iii. p. 689 (1905) ; Sharpe, Ibis, 1906, p. 543 [Ruwenzori].

Mferula baraka Sharpe, Bull. B. O. C. xiv. p. 19 (1903) [Ruwenzori]; Jackson, Ibis, 1906, p. 543.

Turdus baraka Reich. Vög. Afr. iii. p. 687 (1905).

$a-c$. $\delta^{7}$ ㅇ․ Mubuku Valley, E. Ruwenzori, 6000-12,000 ft., 22nd-31st Jan. [Nos. 122.R.E.D.; 1189.D.C.; 3142.R. B.W.]

$d-f$. 0 오. Mubuku Valley, E. Ruwenzori, 5000-12,500 ft., 6th-16th Feb [Nos. 151, 157. R. E. D.; 3 49.R. B.W.]

$g-\not c$. o f et of imm. Mubuku Valley, E. Ruwenzori, 5000-9000 ft., 3rd30 th March. [Nos. 1286. D. C.; 2206, 2208, 2260. G. L.]

Iris dark hazel or dark brown; eyelids yellow ; bill orange ; feet yellow or yellowishbrown. 
I cannot distinguish the Ruwenzori birds, which have been named T. baraka, from typical T. ahyssinicus. Dr. Sharpe, in a note in Mr. Jackson's paper in 'The Ibis' for 1906 , states that he has arrived at the same conclusion.

[The Abyssinian Thrush has the widest range of any bird on Ruwenzori; it was found in the hot tropical valleys at $6000 \mathrm{ft}$., almost side by side with its near relative $T$. centralis of the plains, and was also met with all the way up the mountains to the snow-line. One was actually shot on the Mubuku glacier, but unfortunately it fell down a crevasse and was lost. 'The species was plentiful at $10,00 \mathrm{ft}$., and quite a number were seen between 12,000 and $13,000 \mathrm{ft}$. An old nest was found at an altitude of $11,500 \mathrm{ft}$.; it was placed in the fork of a tree-heath. This species certainly breeds on Ruwenzori up to an altitude of $12,500 \mathrm{ft}$, and probably much higher.-R.B.W.]

I'URdus certratris Reichenow.

Turdus pelios centralis Reich. Vög. Afr. iii. p. 690 (1905).

Merula centralis Jackson, Ibis, 1906, p. 512 ['I'oro].

a. +. Mubuku Valley, E. Ruwenzori, $5000 \mathrm{ft.,}$ 19th March. [No. 2218. G. L.]

b. ․ Mokia, S.E. Ruwenzori, $3400 \mathrm{ft.}$. 28th April. [No. 1451. D.C.]

$c-0$. of et of imm. Molia, S.E. Ruwenzori, $3400 \mathrm{ft}$. 3rd-24th May. [Nos. 284, 285, 325. R. E. D. ; 1484, 1507, 1508, 1525, 1597, 1621. D. C.; 3320 . d.

$3410,3411 . R . M . W$.

1. o. Mokia, S.E. Ruwenzori, $3400 \mathrm{ft.,} 17$ th June. [No. 1636. L.C.]

q. o. Fort Beni, Semliki Valley, $3000 \mathrm{ft} ., 21$ st July. [No. 2420. G. L.]

'The majority of the specimens in the present collection, but not all, appear to be slightly darker on the upperparts than typical examples of T. pelios from Abyssinia.

['This darker form of the Ethiopian 'Thrush was met with plentifully at Eutebbe and throughout the journey to Ruwenzori. It was also found all round the foot of the mountains and at Fort Beni on the edge of the Eturi Forest. It frequents almost exclusively the banana-plantations and cultivated lands, and probably obtains much of its food from the fresh deposits of irrigation. It was found in the lower valleys of Ruwenzori up to $5000 \mathrm{ft}$., above which its place was taken by $T$. abyssinicus.R. li. II.

\section{Callene equatorialis Jackson.}

Callene aquatorialis Jackson, Bull, B. O. C. xvi. p. 4.6 (1905) [Lumbwa].

$a, b$. $q$ et $q$ imm. Mpanga Forest, Fort Portal, 5000 ft., 21st Sept. [Nos. 3558, 3605. R. B.W.]

'The type-specimen, which was procured by Mr. Jackson at Kericho, in Lumbwa, VOL. XIX.-PARE IV. No. 49.-March, 1910. 
appears to be an adult male, but the sex is not indicated. There are three adult female specimens from 'Toro in the Jackson Collection which agree perfectly with the adult female from Mpanga, and all differ slightly from the type in having rather more white on the middle of the breast-a difference which is probably due to sex, or may be individual.

This species is easily distinguished from $C$. cyornithopsis Sharpe, from Cameroon, by its rust-red flanks and under tail-coverts.

[A few of these little birds were found in the Mpanga Forest, where they appeared to inhabit the undergrowth only. $-R . B . W$.

Cossypha archeri Sharpe. (Plate XVI. fig. 2, o*.)

Cossypha archeri Sharpe, Bull. B. O. C. xiii. p. 9 (1902) [Ruwenzori].

a-c. o ㅇ․ Mubuku Valley, E. Ruwenzori, 6000-9000 ft., 5th-26th Jan. [Nos. d.

1096, 1148, 1185. D.C.]

d-h. o ㅇ. Mubuku Valley, E. Ruwenzori, 7000-11,000 ft., 2nd-23rd Feb. [Nos. 140.R. E. D.; 2155. G. L.; 3159, 3165, 3176. R. B. W.]

$i, k$. o 오. Mubuku Valley, E. Ruwenzori, 6500-8000 ft., Sth \& 18th March. [Nos. 1307. D. C. ; 3233, R. B. W.]

This species was first described from a male procured by Mr. Geoffrey Archer. The female does not differ in plumage from the male, but is slightly smaller-wing $2 \cdot 75-2 \cdot 9$ inches.

[Archer's Robin-Chat was found on Ruwenzori from $6000 \mathrm{ft}$. up to $13,000 \mathrm{ft}$. It was one of the few birds that were fairly numerous in the bamboo-zone. It has a curious melancholy piping note, like a cart-wheel which wants oil and creaks each time it comes round to a certain spot. It frequents the undergrowth only and is never seen up in the trees.-R. $B . W$.

\section{Cossyria heuglini Hartl.}

Cossypha heuglini Reich. Vög. Afr. iii. p. 758 (1905); Jackson, Ibis, 1906, p. 544 ['Toro].

a,b. of ㅇ. 120-150 miles W. of Entebbe, $4000 \mathrm{ft} .9$ th \& 11th Dec. [Nos. 2027. G. L. ; 305:. R. B. H.]

c, d. ․ Mubuku Valley, E. Ruwenzori, $5000 \mathrm{ft} ., 20 \mathrm{th}$ Jan. [No. 2101, 2102. G. L.] e. o imm. " ", "27th March. [No. 225. R. E. D.] f. 우 imm. Mokia, S.E. Ruwenzori, $3400 \mathrm{ft} ., 28 \mathrm{th}$ April. [No. 2ะ97.G. L.]

$g-q$. o o f et o imm. Mokia, S.E. Ruwenzori, $3400 \mathrm{ft}$. , 3rd-26th May. [Nos. $345,367,368,378,381 . R . E . D . ; 1487,1512,1526 . D . C . ; 3385,3392 . R . B . W$. 
$r-x$. ot et of imm. Mokia, S.E. Ruwenzori, $3400 \mathrm{ft} ., 1$ st-16th June. [Nos. 404, $\left.412,420,435,465 . R . E . D . ; 3460,3489 . R . B . W_{0}\right]$

Iris brown or dark hazel; bill and feet black.

Immature birds have the greater wing-coverts and innermost secondary quills narrowly tipped or spotted at the extremity with pale orange-buff. The development of the light chestnut nuchal collar and the colour of the mantle appears to be vary greatly in different individuals, irrespective of age; but, as a rule, the older birds have the mantio greyer, while in younger examples it is strongly washed with rufous-olive.

[Heuglin's Robin-Chat was seen throughout the journey from Entebbe to Ruwenzori. It was very plentiful on the plains around the south end of the mountains, but was never seen on the range above $5500 \mathrm{ft}$. 'This bird has some wonderful flute-like notes, but too disconnected to be really called a song. $-R, B . W$.

Cossypha bartteloti Shelley.

Cossypha bartteloti Shelley, Ibis, 1890, p. 159, pl.v. [Yambuya].

Cossypha cyanocampter bartteloti Reich. Vög. Afr. iii. p. 758 (1905).

a. . . Mpanga Forest, Fort Portal, $5000 \mathrm{ft} ., 20$ th Sept. $\quad[$ No. 3587. R. B. W. $]$

Iris dark brown; bill black; feet dark brown.

This specimen, a fully adult male, resembles the type of $C$. bartteloti from the Aruwimi River both in its paler coloration and smaller size. Culmen 0.75 inch, wing $3 \cdot 2$, tail 2.6. 'The olive-brown feathers of the back are fringed with dark bluish-slate-colour, but in this respect it resembles a fine male example of C. cyanocampter (Bonap.) from the River Ja, Cameroon. Most of the Cameroon birds have the chin, throat, and breast darker cinnamon-rufous than in $C$. bartteloti, but this is by no means invariably the case, and it seems that the latter form is barely separable from C. cyanocampter except in size. C. periculosa Sharpe, from the River Danger, Gaboon, is another doubtfully distinct form, with the mantle a trifle browner and darker than in typical C. cyanocampter. The type-specimen appears to be fully adult and the slightly darker colour of the back is probably individual.

In the type-specimen of $C$. bartteloti the middle tail-feathers are missing, and the figure given in the 'Ibis' is therefore misleading, as it represents a bird with a cinmamonrufous tail.

\section{Cossjpina melanotota (Cab.).}

Cossypha verticalis melanonota Reich. Vög. Afr. iii. p. 762 (1905) ; Sharpe, Ibis, 1908, p. 121 [S. Cameroon].

a. ठ. Mubuku Valley, E. Ruwenzori, $5500 \mathrm{ft.}$, 21st Feb. [No. 1252. D. C. ]

๖. o imm. Mokia, S.E. Ruwenzori, $3400 \mathrm{ft}$., Sth May. [No. 2349. G. L.] 
c. ㅇ imm. Fort Beni, Semliki Valley. $3000 \mathrm{ft}$, 20th July. [No. 2418. G. I. ]

Iris dark hazel; bill and feet black.

This form differs only from $C$. verticalis Hartl. in having the mantle slightly darker.

Specimen $\alpha$ is marked "breeding." Specimen $c$ is a young female in a very interesting stage of plumage: the feathers of the crown appear spotted, being rufous margined with black, and amongst them a few white feathers of the adult plumage are making their appearance. Specimen $b$ is in nearly mature plumage, but the wingcoverts are margined with greyish-brown and spotted at the extremity with pale rufous.

[A few examples of the Black-backed Robin-Chat were met with in the lower valleys on the east side of Ruwenzori, but they were never seen above an elevation of $5000 \mathrm{ft}$. and were rather rare birds. A single specimen was shot in the dry acacia-country at the south end. $-R . B . W$. ?

Neocossypuus prepectoralis Jackson.

Neocossyphus prepectoralis Jackson, Bull. B. O. C. xvi.p. 90 (1906) [Kibera, Toro]; Grant, Ibis, 1908, p. 300 [part., Mpanga]; Alexander, Bull. B. O. C. xxiii. p. 15 (1908).

๙. ․ Mpanga Forest, Fort Portal, 5000 ft., 13th Sept. [No. 3553. R. B. W.

'The specimen procured by Mr. Douglas Carruthers at Kasongo, Upper Congo, and provisionally referred by me to the above species, has now been separated by Mr. Alexander under the name of $N$. granti.

[The single example of this rare species shot among the dense undergrowth was the only specimen seen.- $R, B . W$.

ERytmRopygia RUficauda Sharpe.

Erythropygia ruficauda Reich. Vög. Afr. iii. p. 783 (1905).

a-f. o f. Mokia, S.E. Ruwenzori, $3400 \mathrm{ft}$, 3rd-19th May. [Nos. 292. R. E. I).; d.

1488, 1607. D. C.; 2345. G. L.; 3345, 3381.R.B.W.

$g-i$. ot ot imm. Mokia, S.E. Ruwenzori, $3400 \mathrm{ft}$, 6th-24th June. [Nos. 1665, 1676. D.C.;3456.R. B.W.]

Iris dark hazel or brown; bill black, yellow at the base of the lower mandible; feet varying from brown to pale flesh-colour.

[Sharpe's Chestnut-tailed Ground-Robin was not uncommon on the plains and dry hills at the south end of Ruwenzori, wherever there were acacia-trees, and it was also observed in the Semliki Valley. It has a short sweet song, generally uttered from the top of an acacia-bush.- $R . B . W$.

Erythropygia hartlaubi Reichenow.

Erythropygia hartlaubi Reich. Vög. Afr. iii. p. 775, pl, xxix. fig. 1 (1905).

Cossypha griseistriata Sharpe, Bull. B. O. C. xiii. p. 8 (1902) [type examined: Kangor's, Toro]. 
a. b. o. Mubuku Valler, E. Ruwenzori, 6000 ft., 15th \& 22nd Jan. [Nos. 101, 123.R.E. D.]

c. ठ. Mubuku Valley, E. Ruwenzori, $6000 \mathrm{ft.,} \mathrm{1st} \mathrm{Feb.} \mathrm{[No.} \mathrm{137.} \mathrm{R.} \mathrm{E.} \mathrm{D.]}$

Iris dark brown or hazel; bill brown or black; feet brown or light brown.

Specimens $b$ and $c$ are marked "breeding."

[A few examples of Hartlaub's Ground-Robin were met with in the Toro district and in the valleys on the east side of Ruwenzori up to $6000 \mathrm{ft}$. 'These birds were only observed among the elephant-grass and were by no means common. Towards evening one occasionally saw one of them perched on the top of a tall grass-stem, giving vent to a succession of loud clear whistles, and I once saw one near the ground, bobbing up and down on a grass-stem and going through a kind of dance, with its tail spread out like a fan; but I failed to ascertain the cause, as there was no other bird near it. Perhaps it was only joy at having found an open space among the endless elephantgrass. $-R, B: W$.

Aletile Poliothorax Reichenow.

Alethe poliothorax Reich. Vög. Afr. iii. p. 746 , pl. xxvii. fig. 1 (1905).

Alethe moori Alexander, Bull. B. O. C. xiii. p. 37 (1903) [Fernando Po].

a. đimm. Mubuku Valley, E. Ruwenzori, $8000 \mathrm{ft.,} 13$ th Jan. [No. 2080. G. L.]

b. o vix ad. $" \quad " \quad 7000 \mathrm{ft} .30$ th Mar, [No. 2259. G. L.]

Iris reddish-brown; upper mandible black, lower slate-grey; feet slate-blue.

This species has hitherto been recorded only from Cameroon and Fernando Po. Mr. Alexander has kindly lent me the type of $A$. moori Alex, which appears to be synonymous with $A$.poliothorax, and closely resembles the Ruwenzori specimens. They differ, however, in the following points :-

Specimen $a$, which is obviously an immature bird, as is shown by its swollen gape, lias the general colour of the back deep orange-brown, rather than deep chestnut-brown, and the crown is reddish-olive-brown instead of dark vandyke-brown. Specimen $b$, a somewhat older bird, has the back of a more chestnut tint, much as in the type of A. moori, but the crown is reddish-olive-brown as in specimen $a$. The underparts are alike in all three specimens.

['Two examples of this rare Robin-Chat were obtained by Mr. Gerald Legge in the forest-zone of Ruwenzori at an elevation of from 7000 to $8000 \mathrm{ft}$. 'They were shot while skulking along in the thick undergrowth. The species has a curigus harsh note. It was not met with either in the Congo or Mpanga Forests.- R. B.W.]

\section{AleTHE POLIOPHRYS Sharpe.}

Alethe poliophrys Sharpe, Bull. B. O. C. xiii. p. 10 (1902) [Ruwenzori]; Reich. Vög. Afr. iii. p. 749 (1905); Jackson, Ibis, 1906, p. 544. 
a, b. of et $q$ imm. Mubuku Valley, F. Ruwenzori, 7000-8000 ft., 11th \& 16th Jan. [Nos. 1133. D. C.; 3113.R. B. W.]

c-e. . . Mubnku Valley, E. Ruwenzori, 6500-8000 ft., 9th-24th Feb. [Nos. 1223, (1) 1225, 1265. D. C.]

$f-l$. $\delta$ o et of imm. Mubuku Valley, E. Rurvenzori, 7000-9000 ft., 1st-24th March.

[Nos. 195, 196, 197. R. E. D. ; 1277. D. C.; 2212, 2237. G. L.]

Iris dark brown, chestnut, or dark hazel; bill black; feet whitish, pale flesh, or pale brown.

The type-specimen of this very distinct species was procured by Mr. Geoffrey Archer during his short visit to Ruwenzori in February 1902.

[The Grey-eyebrowed Robin-Chat was found on Ruwenzori at elerations of from 6500 to $9000 \mathrm{ft}$., frequenting the forest-zone and the lower edges of the bamboo. It appeared to be particularly fond of the soldier-ants and might often be seen attacking a column of these insects as they crossed a path or open spot. Whether it really ate the ants, or merely snatched away the eggs they were carrying, was a point we could never decide; probably the eggs were the attraction, for it seems difficult to imagine anything more unsatisfactory than a meal of angry soldier-ants. $-R . B . W$.

Aletue woosmani Grant. (Plate XV. fig. 1, đ̋.)

Alethe woosnami Grant, Bull. B. O. C. xix. p. 24 (1906).

a. o . Eturi Forest near Irumu, $3000 \mathrm{ft.g}$ 18th Aug. [No. 3550.R. B.W. Type of the species.]

In general appearance the adult male of this species is similar to $A$. diademata (Bonap.), but is rather larger and has all the tail-feathers black to the tip. The upperparts, especially the lower back and rump, are more rufescent.

The iris is hazel, the bill black, and the feet grey. Total length $7 \cdot 2$ inches; wing 3.9 ; tail (in moult) 3.15 ; tarsus 1.05 .

[A single specimen of Woosnam's Robin-Chat, the only one seen, was obtained at the bottom of a densely-wooded valley which joins the Eturi Forest near Irumu.R. I. II.]

Aletile carruthersi Grant. (Plate XV. fig. 2, o .)

Alefhe carruthersi Grant, Bull. B. O. C. xix. p. 25 (1906).

a. o. 150 miles W. of Entebbe, 5000 ft., 12th Dec. [No. 1059. D. C. Type of the species.]

b, c. o. Mpanga Forest, Fort Portal, 5000 ft., 14th \& 21st Sept. [Nos. 3557, 3597. R. B.W.] 


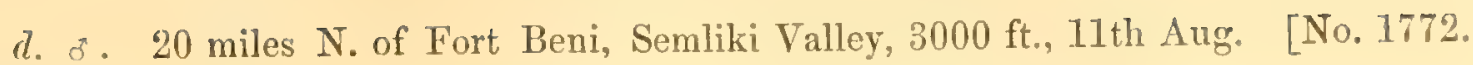
D. C.]

This species is most nearly allied to $A$. castanonota Sharpe, but has the upperparts darker and of a more reddish-brown colour, instead of bright chestnut, the throat pure. white, the chest and sides brownish-buff, and the middle of the breast and belly white. Iris dark hazel or chocolate; bill black; feet pale brown.

5. Total length 6.0 inches; wing 3.5 ; tail 2.15 ; tarsus 1.05 .

There are two female examples of this species from Toro in Mr. Jackson's collection. q. Total length $6 \cdot 0$ inches; wing $3 \cdot 4$; tail $2 \cdot 25$; tarsus $1 \cdot 05$.

[Carruthers's Robin-Chat was decidedly a rare bird. A few examples were met with in the Eturi Forest and in the Mpanga Forest to the east of Ruwenzori.-R. B. W.]

Pratincola Rubetra (Linn.).

Pratincola rubetra Reich. Vög. Afr. iii. p. 731 (1905); Jackson, Ibis, 1906, p. 545.

$a, b$. o et $q$ imm. 40 miles W. of Entebbe, $3500 \mathrm{ft}$., $27 \mathrm{th}$ Nov. [Nos. 12. R. E. I).; 3012. R. B.W.]

$c-g$. o $q$ et $\delta$ imm. 90-150 miles W. of Entebbe, $4000 \mathrm{ft} ., 4$ th-11th Dec. [Nos. 36. R. E. D.; 2019. G. L.; 3028, 3037, 3054.R.B.W.]

Iris dark brown; bill and feet black.

[The Whinchat was seen during the march from Entebbe and in the 'Toro district.-R. B. II.]

\section{Pratincola salax Verr.}

Pratincola salax Verreaux, Rev. Mag. Zool. 1851, p: 307 [Gaboon]; Reich. Vög. Afr. iii. p. 733 (1905).

Pratincola axillaris Shelley, P. Z. S. 1884, p. 556 [Kilimanjaro: type examined].

Pratincola salax pallidigula Reich. Vög. Afr. iii. p. 734 (1905) [Buea, Cameroon].

4. o. 12 miles IV. of Entebbe, $3500 \mathrm{ft}, 24$ th Nov. [No. 3001. R. B.W.]

b, c. o . 120-150 miles W. of Entebue, $4000 \mathrm{ft}$., 8th \& 11 th Dec. [Nos. 3045, 3055. R. B. W.]

d-f. of + Mubuku Valley, E. Ruwenzori, $6000 \mathrm{ft} ., 1 \mathrm{st}-19 \mathrm{th}$ Jan. [Nos. 60. R.E.D.; 2053, 2098. G.L.]

$g, h . \delta$. Mubuku Valley, E. Ruwenzori, $6000 \mathrm{ft} ., 20 \mathrm{th}$ Feb. [Nos. 1247, 1248. D. C.]

i. \$. Mubuku Valley, E. Ruwenzori, $5000 \mathrm{ft} .$, 19th March. [No. 1383. D. C.]

Iris dark hazel or dark brown; bill and feet black.

'The chestnut band across the chest, bordering the black neck, varies greatly in extent in different individuals, quite irrespective of season. In most specimens it is well defined and about half an inch in width, but in some it is much reduced or represented 
only by rufous edges to the black feathers at the base of the neck. It would seem as though the examples in which the chestnut has nearly disappeared were very old birds, for a quite young male in first plumage, with the wing-coverts margined with pale rufous and the breast and belly strongly washed with the same colour, has a wide chestnut band across the chest.

Mr. Carruthers procured a somewhat remarkable specimen (No. 1248). It is marked "ㅇ." The upperparts resemble those of the normal adnlt female, but are somewhat darker. 'The sicles of the head, cheeks, and chin are sandy-brown, much like those of the ordinary female, but the throat and fore-neck are black as in the male; there is a chestnut band across the chest, and the rest of the underparts are white. 'This individual does not appear to be a young male, and there can be little doubt that it is an instance of a very old female assuming plumage like that of the male. Similar instances have been recorded. In Sokotia, I myself procured an undoubted female of Saxicola montana Gould in male plumage ( $c f$. Nat. Hist. Sokotra and Abd-el-Kuri, p. 42).

A female of $P$. salax from Kenya, shot by Dr. R. E. Drake-Brockman, approaches the bird procured by Mr. Carruthers, having the feathers of the throat and fore-neck black, mixed with sandy-brown, but in other respects it is similar to normal females.

From typical $P$. salax from Gaboon Dr. Reichenow has separated the bird found at Buea, Cameroon Peak, under the name of $P . s$. pallidigula, disregarding the fact that Captain Shelley's name $P$. axillaris was given to the bird from the same locality (Cameroon, $7000 \mathrm{ft}$.) and has many years' priority. 'The latter is added to the synonymy of $P$. salax, to which $P$. pallidigula is certainly also referable.

[This Stonechat was met with throughout the journey from Entebbe to Ruwenzori, and was found on the mountains as high as $6500 \mathrm{ft}$., where the forest commences R. IB. TI.]

IrRMeCocichla NigRA (Vieill.).

Myrmecocichla nigra Reich. Vög. Afr. iii. p. 706 (1905) [part.]; Grant, Ihis, 1908, p. 299 [Upper Congo].

a-c. o ㅇ․ 40-50 miles W. of Entebbe, $3500 \mathrm{ft}, 27$ th \& 28 th Nov. [Nos. 13, 14. R. E. D.; 3009. R. B.W.]

d-g. o + . Molia, S.E. Ruwenzori, $3400 \mathrm{ft.}$, 4th-21th Mry. [Nos. 297. R. E. D.; 2330, 2371, G. L. ; 3393. R. B.W.]

h, i. o ㅇ. Nokin, S.E. Ruwenzori, $3400 \mathrm{ft}$., Tth-13th June. [Nos. 436, 454. R.E. D.]

Iris dark brown; bill and feet black.

The characters which distinguish this Black Chat from $M$. amotti (Tristr.) are fully set down in my paper published on Mr. Carruthers's collection and referred to above. Though united under one heading by Dr. Reichenow they are really very distinct species. 
['The Black Bush-Chat was seen near Entebbe and during the march to Ruwenzori. It was plentiful on the plains all lound the mountains, especially at the south end, but was never found above $5000 \mathrm{ft} .-R . B . W$.

\section{Family 'T I M L L I D E.}

\section{Crateropes hirki Sharpe.}

Cruteropus jardinei kirki Reich. Vög. Afr. iii. p. 659 (1905).

Crateropus jardinei hypostictus (ab. \& Reich.; Reich. t. c. p. 660.

a, b. q. 100 miles W. of Entebbe, 4100 ft., 4th Der. [Nos. 25, 26. R. E. D.]

c, d. o et $q$ imm. Mokia, S.E. Ruwenzori, $3400 \mathrm{ft.}, 24$ th \& 28 th April. [Nos. 234, 219. R.E.D.]

$e-l$. o o et $q$ imm. Nokia, S.E. Ruwenzori, $3400 \mathrm{ft} ., 2 \mathrm{nd}-31$ st May. [Nos. 36ㄹ, 399. R. E. D.; 1495, 1496, 1559. D. C.; 2314, 2318. G. L.]

Adult. Iris yellow; bill and feet black.

Imnature. Iris dark grey; bill black; feet brown.

'Ihis species differs from C. jardinei Smith, from S. Africa, in being altogether somewhat smaller. Immature birds have the breast and belly pale brownish-white, slightly washed with rufous on the sides, and exhibit a stage of plumage which Dr. Reichenow has regarded as representing a separate subspecies, C. jardinei kirki. His $C . j$.hypostictus is founded on the adult of this form, which must be known as C. Kirki, that name having priority.

'The type of $C$. kirki is an immature bird from Mazaro, near the mouth of the Zambesi.

In four adult males the wing-measurement varies from 3.75 to 4 inches.

In five adult females the wing-measurement varies from $3 \cdot 9$ to $4 \cdot 1$ inches.

In three immature females the wing-measurement is 3.85 inches.

In typical C.jardinei the wing-measurement varies from about 4.3 to 4.55 inches.

\section{Crateropus smarpei Reichenow.}

C'rateropus melanops sharpei leich. Vög. Afr. iii. p. 661 (1905).

Crateropus sharpii Jackson, Ibis, 1906, p. 541 ['T'oro].

a. o. 100 miles W. of Lntebbe, $4000 \mathrm{ft}$., 7th Dec. [No. 32. R. E. D.]

b, c. +. Mokia, S.E. Ruwenzori, 3400 ft., 25̃th \& 30th April. [Nos. 2284. 2305. G. L.]

d, e. o*. Mokia, S.E. Ruwenzori, $3400 \mathrm{ft} ., 26 \mathrm{th}$ \& 2Sth May. [Nos, 380, 38s. I. L. L.]

f, g. of o. Mokia, S.E. Ruwenzori, 3400 ft., 14th \& 10th June. [Nos. 456. R. E. D.; 2393. (i. L. L.]

FOL. XIX.-PART IV. No. 50.-March, 1910. 
Iris white; bill black; feet black or brown.

[Both Kirk's and Sharpe's Babbling-'Thrushes were seen throughout the journey from Entebbe to Ruwenzori. 'They were very common birds in the acacia-country at the south end of the range and in the upper Semliki Valley. 'They were always observed going about together in noisy parties, and were very inquisitive. $-R . B . W$.]

Phyldaxthus czarxinowi Grant. (Plate XVII. fig. 1, o .)

Phyllanthus czarnikowi (irant, Bull. B. O. C.xix. p. 40 (190б).

a. d. Mawambi, E. Congo Forest, $3000 \mathrm{ft}$, 18th ()ct. [No. 3633. R. R.W. Type of species.]

Czarnikow's Babbler is most nearly allied to P. bohnlorffi (Sharpe), but differs in having the forehead, fore-part of the face, and the chin black; the feathers of the crown blackish, with grey margins; and the chestnut of the upper- and underparts darker in colour. Iris claret-colour; bill pale yellow; fect pale greenish-grey.

Total length ca. 8.5 inches; culmen 1.05 ; wing 4.6 ; tail 3.2 ; tarsus $1 \cdot 45$.

In the type of $P$. bohndorffi, which is no doubt an immature bird, the feet are whitish (in the dry skin).

Mr. Alexander procured three examples of this species on the Welle River.

['The type-specimen of Czarnikow's Babbling-'Thrush was obtained in the Congo Forest, and was the only one seen. It was shot among the dense undergrowth.li. Ii. H.]

\section{Macrosphenus flavicans Cassin.}

Macrosphenuis flavicans Reich. Vög. Afr. iii. p. 615, pl. xxii. fig. 3 (1905); Sharpe, Ibis, 1908, p. 117 [Cameroon].

Macrosphenus zenkeri Reich. t. c. p. 615, pl. xxii. fig. 4 (1905).

$n-c$. of 우 et $0^{*} \mathrm{imm}$. Fort Beni, Semliki Valley, $3000 \mathrm{ft}$, 21st \& 23rd July. [Nos. 49.2, 494. R. E. D.; 1733. D.C.]

d. 020 miles N.W. of Fort Beni, $3000 \mathrm{ft} ., 11$ th Aug. [No. 506. R. E. D.]

C. o. Arakubi, E. Congo Forest, $2500 \mathrm{ft}$., 31st Oct. [No. 3653. R. B.W.]

Iris yellow, dark brown in the immature male; bill black; fect grey or bluish-ash.

There can be no doubi that, as has already been suggested by Dr. Sharpe, $M I$. zenkeri is founded on immature examples of $M$. flavicans. In aldition to the young male (specimen c) mentioned above, there is an immature female in the British Muscum procured at Efulen, Camcroon, by Mr. G. L. Bates, which agrees exactly with the description and figure of $M$. zenkeri given by Dr. Reichenow.

[This Long-billed Bush-Warbler was seen only in the Congro Forest, where it was not uncommon. It was usually observed climbing about among the tangled masses of creepers which hung from the trees.- $R . B . W$. 
Turdinus fut,vescens (Cassin).

Turdirostris fulvescens Cass. P. Ac. Philad. 1859, p. 54 (part.) [R. Camma].

Turdinus fulvescens Reich. Vög. Afr. iii. p. 736 (1905) [part.]; Sharpe, Ibis, 1908, p. 120 [Cameroon].

Turdinus altipectus Reich. Vög. Afr. iii. p. 738, pl.xxx. (1905); Sharpe, Ibis, 1908, p. 121 [Cameroon].

Turdinus bocagei Salvad. Boll. M[us. Tor. no. 44.2, p. 1 (1903) [Feruando Po].

Turdinus barakce Jackson, Bull. B. O. C. xvi. p. 90 (1906) ['Toro].

a. o. Irumu, Eturi Forest, 3000 ft., 17th Oct. [No. 3630.R. B. W.]

Iris brown; bill and feet dark horn-colour.

Dr. Reichenow has doubtfully referred T. cerviniventris Sharpe, from Conde, near the mouth of the Congo, to the synonymy of $I$. fulvescers Cassin, the types of which were procured by Du Chaillu on the Camma River, Gaboon. 'The British Museum possesses the type of the first-named species and two cotypes of the latter, also from the Camma River ( $D u$ Chaillu), and on comparing these it is at once apparent that they belong to two totally different species. I quite agree with Mr. Alexander in regarding $T$. albipectus Reichenow as synonymous with $T$. fulvescens. They are separated from one another in Dr. Reichenow's "Key to the Species" by the length of the wing, which is said to be $80 \mathrm{~mm}$. long or more in T. fulvescens. This, however, is not the case and the length is quite correctly given by Cassin as 3 iuches (=76 mm.). In T.albipectus the wing is said to measure $73 \mathrm{~mm}$.

The British Museum now possesses a series, both adult and immature, of typical examples of T. bocagei Salvad. from Fernando Po, and there can be no doubt that this name must also be added to the symonymy of $T$. fulvescens.

In my opinion Dr. Reichenow has admitted far too many species of T'urdinus, and the bird he describes as $T$. bocagei is certainly the redder-winged, redder-tailed, and whiter-breasted immature stage of $T$. fulvescens (Cass.).

$T$. barakce Jackson is no doubt also referable to $T$. fulcescens, and is founded on $A$ nearly adult female of that species. Mr. Jackson compared it with the grey-throated T. jacksoni Sharpe, to which it is not very closely allied.

Adult males have the breast and underparts greyer, with less olire-brown on the flanks and less white in the middle of the belly.

Adult females and younger birds have the sides and flanks olive-brown and the middle of the belly white, sometimes very white in younger birds.

Younger birds have also the upperparts, wings, and tail much more rufous, and the fenthers of the breast indistinctly margined with brownish-olive, producing a faintly scaled appearance.

[This Babbler was plentiful in the Eturi Forest, where it fiequented the darkest parts and was generally to be seen in small parties of four or five individuals hopping along close to the ground among the densest undergrowth and continually uttering a 
low twittering note. 'The birds always appeared to be following a definite course and did not wander aimlessly about. Both in their habits and notes they exactly resembled Alcippe jackvoni Sharpe, from Ruwenzori, but they were never to be met with on the mountains, although found both to the east and west of the range.- $R . B . W$.

\section{'T'URdixts Cenvinivextris Sharpe.}

Turdinus cervinitentris Sharpe, Bull. B. O. C. xii.p. 3 (1901) [Conde, Congo R.].

a. 3. Mpanga Forest, Fort Portal, $5000 \mathrm{ft}$., 21st Sept. [No. 3598. R. B.W.]

In many specimens of $T$. cerviniventris the feathers of the throat have indistinct grey shaft-streaks, producing a general greyish appearance. In others the throat is pure white. I cannot see that this difference has any connection with either distribution or age. Mr. Alexander has kindly sent me his fine series for comparison.

I may here remark that $T$. richenowi Sharpe [nomen emend., of. Hand-1. iv. p. 33 (1903)] is a pure synonym of $T$. cerviniventris, being founded on T. mufiventris Reich. (nec Salvad.) Orn. Monatsb. i. p. 177 (1893), a name gyiven to specimens collected by Dr. G. Zenker in Cameroon. 'The British Museum possesses two specimens procurerl by the same collector in the same locality. 'These I have compared with the type of I'. cerviniventris from the Congo, and there can be no doubt that they belong to one and the same species.

[A few examples of this Babbler were seen in the Mpanga Furest, Eastern Ruweuzori. Its hubits were similar to those of $T$. fiulvescens. $-R . B . W$.

'Terdixus pyremopterus (Reichenow \& Neumann).

Turdinus pyrrhoptenus Reich. Vög. Afr. iii. p. 735 (1905).

Turdinus jucksoni Sharpe, Bull. B. O. C. xi. p. 29 (1900) [Nandi].

Turdinus yyrrhopterus kivuensis Neumann, Bull. B. O. C. sxi. p. 55 (1905) [Mufumbiro Volcanoes]; Grant, Bull. B. O. C. xxi. p. 60 (1908).

a-d. o f. Mubuku Valley, E. Ruwenzori, 6000-9000 ft., Jth-1Sth Jan. [Nos. 98. R.E. D. ; 1125, 1168. D.C.;3089. R. B. W.

e, f. o . Mubuku Talley, E. IRwenzori, 6500-\$000 ft, 7 th \& 24th Feb. [Nos. 1220, 1267. D.C.]

g, h. o ․ . Mubuku Valley, E. Ruwenzori, 7000-8000 ft., 20th \& 22nd March. [Nos. $3246,3250 . R . B . W$.

i. ơ. Mubuku Valley, E. Ruwenzori, $9000 \mathrm{ft}$, sth April. [No. 3269. R. B.W.]

Iris light brown or reddish-brown; bill blackish or grey, lighter on the lower mandible; feet slate-grey or brownish-grey.

Professor Neumann has separated a specimen from Mt. Sabjingo (Sabyino), Mufumbiro Volcanoes, uuder the name of $T \cdot p$. kivuensis on account of its supposed greyer head, and has referred all the Rurrenzori specimens to that subspecies. When, however, 
these latter were lail out in a series with typical specimens of $T$. pyrrhopterus from Nandi and the Mau escarpment it was found impossible to separate one from the other.

Younger birds have the crown of the head washed with olive, while in the oldest examples the grey colour predominates on this part.

[Jackson's Babbler was met with on Ruwenzori from 6500 up to $9000 \mathrm{ft}$. It inhabited the forest-zone and was occasionally seen in the lower parts of the bamboo. It was usually met with in small parties of four or five individuals, which hopped along close to the ground among the densest undergrowth and continually uttered a low twittering note. They always seemed to be travelling in a definite direction. Their habits and notes exactly resembled those of Turdinus fulvescens from the Eturi Forest.li. li. II.]

\section{TURdinus ATRICEPS Sharpe.}

Turdinus atriceps Sharpe, 13ull. B. O. C. xiii. p. 10 (1902) [Ruwenzori]; Reich. Vög. Afr. iii. p. 740 (1905); Jackson, Ibis, 1906, p. 541 [Rumenzori]; Grant, Ibis, 1908, p. 30 [Nufumbiro Volcanocs].

a-g. of ․ . Mubuku Valley, E. Ruwenzori, 6000-9000 ft., 2nd-20th Jan. [Nos. 95, 116. R. E. D.; 2076. G. L.; 3063, 308т, 3092, 3093. R. B.W.]

h-l. o ‥ Mubuku Valley, E. Ruwenzori, 6500-8000 ft., 10th-26th Feb. [Nos.

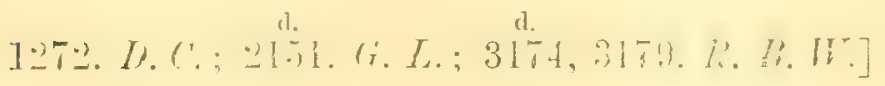

m-s. of. Mubuku Valley, E. Rurenzori, 6500-8000 ft., 8th-24th March. [Nos. $304,1309$. D.C.; 2216, 223S, 2211. G. L. ; 3193, 3238. R. B. W.

t. ․ Butagu Talley, W. Ruwenzori, 7000 ft., Ist Aug. [No. 3527.R. B. W.]

Iris dark brown or dark hazel ; bill black ; feet slate-grey or in one example (No. 116) olive-browu.

[The Black-headed Babbler was found on Ruwenzori from 6500 to $9000 \mathrm{ft}$., frequenting the forest-zone and occasionally the lower part of the bamboo. In habits it much resembles $T$. pyrrhopterus, going about in small parties of four or five individuals. They hop along through the ferns and tangled vegetation, all following the same direction, and from time to time utter a low twittering note, exactly like that of a Swallow when in search of a nestine-site. This bird also has a most beautiful clear song, which was generally uttertd from high up in some dense mass of tangled creepers.-R. B. W.]

\section{BathMEDONIA JACESONI (Sharpe).}

Bathmocercus jacksoni Slarpe, Bull. B. O. C. xiii. p. 10 (1902) [Kibera, Toro].

Bathmedonia jacksoni Jackson, Ibis, 1906, p. 54:.

Bathmedonia rufa Reich. Vüg. Afr. iii. p. 742 (1905) [part.]. 
a-e. 0 ㅇ. Mpanga Forest, Fort Portal, 5000 ft., 14th-24th Sept. [Nos. 552. R.E.D.; 3560,3603, 3604, 3614. R.B.W.]

Iris dark brown or dark hazel; bill black; bare skin on the throat blue; feet grey or blue-grey.

Though closely allied this species is certainly not synonymous with $B$. rufa Reich. In addition to the differences already pcinted out by Dr. Sharpe ( $c f$. 'Ibis,' 1906, p. 542), I may mention that in $B$. jacksoni the black on the forehead extends rather further back, to the posterior margin of the eyes, and the belly, sides, and flanks are washed with olive, as in younger examples of $B$. ruf $a$ from Cameroon. In adult specimens of $B$. mufa these parts are nearly uniform dark grey.

The females of the two species differ even more than the males, the light creamy border to the black feathers of the throut and breast in $B$. jacksoni being dull olive in 13. rufa.

[Jackson's Bush-Tarbler was plentiful in the Ifpanga Forest, E. of Ruwenzori. It frequented only the low undergrowth, especially in low-lying damp places, and was never scen on the range.- $R . B . W$.

Family PуC NохотID.玉.

Crintger calures (Cassin).

Criniger calurus Reich. Vög. Afr. iii. p. 382 (1904); Grant, Ibis, 1908, p. 304 [Kasongo, Upper Congo].

a. o . Irumu, Eturi Forest, $3000 \mathrm{ft} ., 18$ th Oct. $[$ No. 3636. R. B. W.]

b. ․ Fort Beni, Semliki Valley, 3000 ft., 21st July. [No. 1734. I). C.]

Iris dark grey or chestnut; bill dark grey, blacker on the culmen; feet grey.

'This species was known only from West Africa, until Mr. Carruthers procured two specimens on the Upper Congo.

[Two specimens of Du Chaillu's Bulbul were obtained in the Eturi Forest, but it appeared to be rather uncommon. $-R . B . W$.

Xexocichla kinutemsis Sharpe. (Plate XIX. fig. 20, egg.)

Xenocichla kikuyuensis Sharpe, Ibis, 1891, p. 118 [Kikuyu].

Bleda kikuyuensis Jackson, Ibis, 1906, p. 539 [Ruwenzori].

Phyllastrephus kikuyuensis Reich. Vög. Afr. iii.p. 393 (1901).

$a-\imath$. of $q$ et o imm. Mubuku Valley, E. Rurenzori, 6500-9000 ft., 4th-1Sth Jan. [Nos. $77,97,99 . R . E . D . ; 1104,1110,1115,1119,1151$. D. C. ; 2055, 2058, 2074 , 2077, 2094, 2097. G. L.; 3085, 3094, 3095, 3102, 3115, 311s. R. B.W.] 
v, w. o . Mubuku Valley, E. Ruwenzori, 10,000 ft., Ist-3rd Feb. [Nos. 1208,

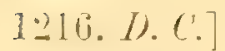

Iris dark brown; bill black; feet olive-brown, greenish-brown, or brown.

The genera forming this section of the Pycnonotidx are greatly in need of revision; at the present time the species included in them are in a state of confusion. For instance, such birds as the present species and Xenocichla albigularis Sharpe are both placed by Reichenow in the genus Phyllastrepluts, though structurally they are very different.

An egg of this species is of a rather blunt oval form and slightly glossy. The ground-colour is pinkish-white, heavily blotched and clouded with dark brown and leaden-grey, and with a few indistinct spots of deeper brown. It measures $.11 \mathrm{i} \times \cdot 7 \mathrm{l}$ in.

['The Kikuyu Bulbul is the most plentiful bird found on Ruwenzori. It frequents the forest-zone, but was found in the valleys as high as $10,000 \mathrm{ft}$. It is not a shy bird aud was continually turning up in unexpected places, in the darkest and densest undergrowth, in the tops of the tallest trees, and in the bamboo-jungles. Although really one of the most fumiliar birds to us, it seemed to have a singulurly unfortunate gift of continually appearing to be a quite different bird, and for this reason was constantly being shot by mistake. A nest found on the 4th of March, 1907, on Ruwenzori at $8000 \mathrm{ft}$., was placed in the undergrowth about $5 \mathrm{ft}$. from the ground and was composed of fine roots, grass, and moss; the female was sitting on a single eggo. $-R . b . W$.

\section{XENocichta LIUCOLaM Sharpe.}

Ienocichla lencolama Sharpe, Bull. B. O. C. xiii. p. 10 (1902) [Toro]; Grant, Ibis, 1908, p. 302 [Kasongo, Upper Congo].

Phyilastrephus allagularis Reiclı. (nec Sharpe) Vüg. Afr. iii. p. 400 (1904.) [part.].

Bleda albigularis Sharpe (nec Sharpe, 1881), Ibis, 1907, p. 459 [Cameroon].

a. o. Fort Beni, Semliki Valley, 3000 ft., 24 th July. [No. 1755. D. C.]

Iris dark hazel; bill black; feet grey.

As already remarked ('Ibis,' 190 s, p. 302), this species appears to be distinct from Ienocichla albigularis Sharpe [Cat. Birds B. M. vi. p. 103, pl. vii. fig. 1 (1881)] from Fantee, which is a very much smaller bird. So far as $I$ am aware, the latter is only known from the type-specimen, of which the sex is not indicated.

\section{Xexocichla latissima Sharpe.}

Andropadus lectissimus Sharpe, Bull. B. O. C. x. p. 27 (1899) [Nandi]; Reich. Vög. Afr. iii. p. $410(1901)$.

a-c. o + . Mpanga Forest, Fort Purtal, 5000 ft., 14th-19th Sept. [Nos. 538. R.E.D.; $3562,3574.7 . B . W$. 
The bill of the female is considerably shorter than that of the male.

8. Culmen from nasal opening to tip 0.50 inch; wing 4.3 ; tail 3.9 .

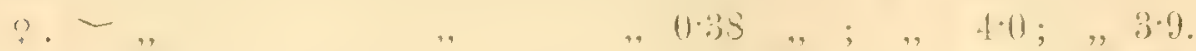

Iris hazel or dark chestnut; bill black; feet grey or light green.

[This handsome Yellow Bulbul was very plentiful in the Mpanga Forest, east of Ruwenzori. They appeared to frequent the tree-tops exclusively and were nerer seen among the undergrowth. They have a very beatiful clear song of great volume, I think the finest $I$ have ever heard in Africa. - R. B. W.]

Bueda woosnami Grant. (Plate XVII. fig. 2, ơ .)

Bleda woosnami Grant, Bull. B. O. C. xix. p. 87 (1907).

a-e. of ㅇ․ Mpanga Forest, Fort Portal, 5000 ft., 15th-23rd Sept. [Nos. 515, $554^{*}$, 558. R. E. D.; 3554, 3596 *. R. B.W.]

This species is most nearly allied to B. syndactyla (Swains.), but the bill, especially in the male, is much shorter and the yellow on the throat and underparts is of a much brighter colour. Iris hazel; bill grey; feet dull flesh-colour.

8. Total length $8 \cdot 8$ inches; wing $4 \cdot 2-4 \cdot 30$; tail $3 \cdot S-4 \cdot 1$; tarsus $1 \cdot 15$.

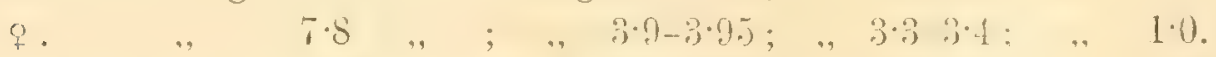

[A fer examples of Woosnam's Yellow Bulbul were met with in the Mpanga Forest, east of Ruwenzori. 'They were always seen in the tall undergrowth, and not in the trees. Late in the evening $I$ once or twice heard this bird attempting to sing, but the result was only a combination of several harsh loud notes.- R. B.W.]

ANdropadus indicator (Verr.).

Phyllastrephus indicator Reich. Vög. Afr. iii. p. 390 (1906).

Bleda indicator Jackson, Ibis, 1906, p. 539 [Toro]; Sharpe, Ibis, 1907, p. 460 [Cameroon].

Bleda batesi Sharpe, Bull. B. O. C. xiv. p. 19 (1903) [S. Cameroon]; id. Ibis, 1904, p. 634.

a. J. Mpanga Forest, Fort Portal, $5000 \mathrm{ft} ., 20 \mathrm{th}$ Sept. [No. 3592. R. B. W.]

b. ․ 80 miles N.IV. of Fort Beni, Semliki Valley, 3000 ft., 15th Aug. [No. 3549. I. B. W. $]$

o. Iris white; bill black; feet dark grey.

₹. Iris greenish-grey; bill black; feet dark grey.

Mr. Jackson has already called attention to the difference in the colour of the eye in the male and female.

B. batesi Sharpe appears to be founded on immature birds, which have the outer tail-feathers pure white. 'This is clearly proved by a female specimen [No. 290] from the River Ja, received from Mr. Bates. This bird has the tail in partial moultone side retaining the feathers of the first plumage, which are pure white, while 
on the other side the new feathers are half-grown and the outer pairs are tipped with black.

[A few examples of the Honey-Guide Bulbul were seen in the Congo Forest near Irumu and also in the Mpanga Forest east of Ruwenzori, but they were not common. The specimens obtained were frequenting the tops of the very tall trees, and, if that is their usual habit, it would account for so few specimens being obtained, as our collectingguns would not kill them at that height. $-R . B . W$.

\section{Andropadus virens Cassin.}

Andropadus virens Reich. Vög. Afr. iii. p. 412 (1904).

Eurillas virens Jackson, Ibis, 1906, p. 540 [Toro].

$a-b$. o . Fort Beni, Semliki Valley, $3000 \mathrm{ft}$, 22nd \& 23rd July. [Nos. 1738. D. C.:2430.G. L.]

Iris, bill, and feet dark brown.

This species and the larger paler A. zombensis Shelley, from Nyasaland, may be distinguished from the allied forms, A. gracilis and $A$. curvirostris, by the shorter broader bill; the throat too is yellow, like the middle of the breast.

['The Small Green Bulbul was very plentiful in the Congo l'orest, but was not seen on the mountains. $-R . B . W$.

\section{Andropadus glacilis Cabanis.}

Andropadus gracilis Reich. Vög. Afr. iii. p. 414 (1904); Grant, Ibis, 1908, p. 303 [Ponthicrville, Upper Congo].

Eurillas gracilis Sharpe, Ibis, 1904, p. 635.

a. o. Fort Beni, Semliki Valley, $3000 \mathrm{ft.}$, 9th Aug. [No. 1770. D. C. ]

b. o. Irumu, Eturi Forest, $3000 \mathrm{ft} ., 16 \mathrm{th}$ Oct. [No.567.R. E. D.]

c. $q$ imm. Nr, Mawambi, E. Cougo Forest, $3000 \mathrm{ft}, 20$ th Oct. [No.572, R. E. D.]

Iris dark hazel or dark brown; bill black; feet olive or olive-green.

I am a little doubtful about the identification of specimen $c$. It has the general colour of the breast brownish-grey with scarcely a trace of yellow, and the sides and flanks warm olive-brown, while the middle of the breast and belly are white tinged with yellow. In the adult of $A$. gracilis these parts are pale rather bright yellow, and the breast, sides, and flanks are washed with the same colour.

I have already at some length drawn attention to the differences between this species and $A$. curvirostris Cassin [ef.' 'Ibis,' 1908, p. 303].

There are examples of this species in Mr. Jackson's collection from Entebbe anrl Kitunzi, Uganda.

[The Slender Green Bulbul was plentiful in the Congo Forest. We did not obtain any examples of this species in the Mpanga Forest to the east of Ruwenzori, but it is very likely to be found there. It has a low and very sweet song.- $R . B . W$.]

VOL. XIX.-PART IV. No.51.-March, 1910. 3े F 
Andropades curvirostris Cassin.

Andropadus curvirostris Reich. Vög. Afr. iii. p. 413 (1904); Grant, Ibis, 1908, p. 303.

Eurillas camerunensis (Reich.); Sharpe, Jbis, 1904, p. 636.

a. q. Mpanga Forest, Fort Portal, 5000 ft., 22nd Sept. [No. 3608. R. B. W.]

Iris hazel; bill black; feet olive-green.

\section{ANDropadus latirostris Strickl.}

Andropadus latirostris Reich. Vög. Afr. iii. p. 414 (1904); Grant, Ibis, 1908, p. 30t [N.W. of Lake Tanganyika].

Andropadus latirostris eugenius Reich. t. c. p. 415.

Eurillas eugenius Sharpe, Ibis, 1902, p. 114. [Mpanga Forest]; Jackson, Ibis, 1906, p. 540 [Toro; Ruwenzori].

Eurillas efulenensis Sharpe, Ibis, 1904, p. 636 [Cameroon].

$a-c .0$. . Mpanga Forest, Fort Portal, $5000 \mathrm{ft.}$, 13 th \& 14th Sept. [Nos. 3554, $3565,3566 . R . B . W$.

$d-i$. $\delta$ q et $\delta \mathrm{imm}$. Mubuku Valley, E. Ruwenzori, 6000-8000 ft., 7th22nd Jan. [Nos. 120, 121.R. E. D.; 1130. D. C.; 2064. G. L. ; 3084, 3091.R. B. W.] k-n. ơ . Mubuku Valley, E. Ruwenzori, 6000-7000 ft., 4th-24th Feb. [Nos. 2144, $2152,2170,2172$. G. L. $]$

o. ơ imm. Mubuku Valley, E. Ruwenzori, $7000 \mathrm{ft.,} \mathrm{24th} \mathrm{March.} \mathrm{[No.} \mathrm{2243.} \mathrm{G.} \mathrm{L.]}$

Iris hazel or dark brown; bill dark brown; feet brown or light brown.

I have already pointed out that $A$. eugenius Reich. cannot be separated from typical cxamples of $A$. latirostris from Fernando $\mathrm{Po}$, and I may further remark that E. efulenensis Sharpe is founded on immature examples of the same species; this may be seen by the light colour of the bill and the less-serrated upper mandible. Adult specimens from Efulen, Cameroon, which have more recently been received from Mr. Bates differ in no way from A. latirostris.

[The Moustached Bulbul was plentiful in the forest-zone on Ruwenzori up to $8500 \mathrm{ft}$., and also in the Mpanga Forest and wooded valleys of the Toro district. It can hardly be said to have a song, but keeps up a ceaseless twittering and chirping in the tree-tops. $-R . B . W$.

\section{Phyminatraphus sucosus Reichenow.}

Phyllastrephus cabanisi sucosus Reich. Vög. Afr. iii. p. 401 (1904).

Phyllostrephus sucosus Jackson, Ibis, 1906, p. 541 ['Toro].

$a-f$. o o et of imm. Mpanga Forest, Fort Portal, $5000 \mathrm{ft}$, 14th-24th Sept. [Nos. 532, 533. R. E. D. ; 3556, 3581, 3612, 3613.R. B.W.]

g. d. Mubuku Valley, E. Ruwenzori, $9000 \mathrm{ft}, 19$ th March. [No. 3245. R. B. IV.] 
Iris brown or olive-brown; bill brown; feet grey, dark grey, or greyish-brown.

I am not quite satisfied about the identification of these birds. P. cabanisi was founded by Dr. Sharpe on a description given by Cabanis of a Bulbul from Angola allied to $P$. icterinus (tricolor): consequently there is no type-specimen.

There are three examples named $P$. cabanisi in the British Museum: one from the Benito River and two from South Cameroon. If these long-billed specimens with strong rictal bristles are correctly identified, they are certainly not very nearly allied to the present species or to P. placidus (Shelley), both of which are considered to be subspecies of $P$. cabanisi by Dr. Reichenow. The Mpanga birds are evidently nearly allied to $P$. placidus, but are paler and more olive above, and much yellower on the underparts.

A single specimen of this Bulbul was killed on Ruwenzori at $9000 \mathrm{ft}$., in the upper part of the forest-belt, and a few examples were met with in the Mpanga Forest. They were usually met with in the undergrowth or low down in the trees. $-R . B . W$.]

Phyllastrephus icterinus (Bonap.).

Phyllastrephus icterinus Reich. Vög. Afr. iii. p. 402 (1901).

Bleda tricolor Sharpe, Ibis, 1907, p. 461 [Cameroon].

Criniger icterina Grant, This, 1908, p. 304 [Kasongo, Upper Congo].

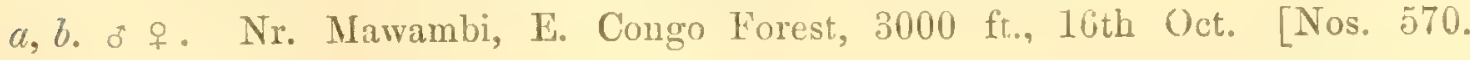
R. E. D.; 3629. R. B.W.]

ठ. Iris grey; bill dusky; feet slate-colomr.

‥ Iris, bill, and feet brown.

[The Yellow-breasted Bulbul was not uncommon in the Congo Forest, but we did not find it in the Mpanga Forest to the east of Ruwenzori. $-R . B . W$.

\section{Ironotus guttatus Verr.}

Ixonotus guttatus Reich. Vög. Afr. iii. p. 416 (1904) ; Sharpe, Ibis, 1907, p. 463 ; Graut, Ibis, 1908, p. 302 [Ponthierville, Upper Congo].

a. o . Mawambi, E. Congo Forest, $3000 \mathrm{ft}$, 29th Oct. [No. 3645. R. B. H.]

Iris dark brown; bill brown; feet dark grey.

As already observed in my paper on Mr. Carruthers' collection, this species was, so far as I am aware, hitherto known only from West Africa.

[This Spotted Bulbul was one of the few birds we obtained out of the tops of the tall trees in the Congo Forest. It was the only example of the species procured. 'The ordinary 410 -bore collecting-gun was almost useless among the tall tree-tops of the Congo Forest and it was always a great surprise when a bird was shot Li. B. W. . 
Prononotus tricolor Hartl.

Pycnonotus tricolor Reich. Vüg. Afr. iii. p. 421 (1905).

Pycnonotus tricolor minor Hcugl.; Reich. t. c. p. 421.

a-c. of ㅇ․ 20-60 miles W. of Entebbe, $3500 \mathrm{ft}$, 26th-29th Nov. [Nos. 2007.

(r. I. ; 3008, 3016. R.B. W.]

d. \&. 100 miles W. of Entebbe, 4000 ft., 6th. Dec. [No. 2021. Ǵ. L.]

e.f. o ㅇ․ Mubuku Valley, E. Ruwenzori, $6000 \mathrm{ft} ., 30$ th \& 31 st Dec. [Nos. 2037, 2044. G. L.]

y-l. $\delta$ f. Mubuku Valley, E. Ruwenzori, $6000 \mathrm{ft.}$, 5th-28th Jan. [Nos. 107. h. E. D.; $2057,2104,2121,2122$. G. L.]

m, n. ơ. Mokia, S.E. Ruwenzori, $3400 \mathrm{ft} .$, sth \& 30th May. [Nos. 397. R. E. D.; 333ะ. R. B. W.

o. f. Nr. Fort Beni, Semliki Valley, 3500 ft., 13th Aug. [No. 1782. D. C.]

Iris dark brown; bill and feet black.

I am unable to recognize $P$. minor Heugl, as distinct from $P$. tricolor.

[Mnteiro's Yellow-rented Bulbul was plentiful throughout the journey from Entebbe to Ruwenzori and was met with all round the mountains as far north as Irumu. It was found on Ruwenzori up to $6000 \mathrm{ft}$., but not above that altitude.R. B. W.]

\section{Family CAMPOPHAG D $x$}

(Ampophaga nigra Vieill.

Cmmpephaga nigra Reich. Vög. Afr. ii. p. 518 (1903).

('mmpophaga nigra Jackson, Ibis, 1906, p. 538 [Ankoli]; Grant, Ibis, 1908, p. 301 [S.W. Uganda].

11. 8. Mokia, S.E. Ruwenzori, $3400 \mathrm{ft}$., 17th June. [No. 469. R. E. D.]

Iris dark brown; bill and feet lack.

[A single specimen of the Black Cuckoo-Shrike was obtained in the acacia-country at the south end of Ruwenzori.-R. B. W.]

Camporhaga Petiti Oustalet.

Campephaga petiti Reich. Vög. Afr. ii. p. 519 (1903) [female].

Campophaga petiti Grant, Bull. B. O. C. xix. p. 87 (1907) [male, Mpanga Forest].

u. o. Mpanga Forest, Fort Portal, $5000 \mathrm{ft}$., 20th Sept. [No. 548. R. E. D.]

The adult male of this species is very similar to that of C. nigra Vieill., but is distinguished by having the under surface of the quills blackish-grey, with or without the faintest tinge of greenish-yellow on the margins of the inner webs. In $C$. nigra 
the inner webs are always conspicuously pale greenish-yellow. Iris dark brown; bill and feet black. 'Total length ca. 8.0 inches; wing 4.1 ; tail 3.5 ; tarsus 0.85 . The single male procured by Mr. R. E. Dent is almost certainly referable to this species. There is another perfectly similar specimen in the British Museum labelled "Gaboon ( $P$. Du Chaillu), Tweeddale Collection," which has been wrongly identified as C. nigre: also an adult female from Angola, procured by J. J. Monteiro and doubtfully referred to C. hartlaubi Salvad.

I have also examined in the 'Tring Museum two males and a female of this species, which, like the bird described above, were also collected in the Mpanga Forest by Herr R. Graner: likewise a male from Nandi, Uganda, obtained by Dr. IV. J. Ansorge.

[A single specimen of Oustalet's Cuckoo-Shrike was obtained in the Mpanga Forest F. of Ruwenzori. It was shot in the top of a tall trec. $-R . B . W$.

\section{Graucalus ceesios Licht.}

Graucalus cesius Grant, Ibis, 1900, p. 171.

Coracina cresia Reich. Vög. Afr. ii. p. 514 (1903).

Coracina pura Reich. Vög. Afr. ii. p. 515 (1903).

Graucalus purus Jackson, Ibis, 1906, 1. 538 [Ruwenzori].

a-g. of et of imm. Mubuku Valley, E. Ruwenzori, 6000-9000 ft., 4th-18th Jan. [Nos. 93, 96. R. E. D.; 1131, 1150, 1165. D. C. ; 2056. G. L.; 3086 . li. li. II.]

hl-m. o ㅇ. Mubuku Valley, E. Ruwenzori, 6000-9000 ft., 3rd-18th Feb. [Nos. 142. 147. R. E. D. ; 1232. D. C.; 2160. G. L.;3146.R.B.W.]

n. ㅇ imm. Mubuku Valley, E. Ruwenzori, $8000 \mathrm{ft}, 21 \mathrm{st}$ March. [No. $324 \mathrm{~S}$. R. B. W.]

Dr. Reichenow and other ornithologists still continue to separate East African examples of this Cuckoo-Shrike from typical G. casius from South Africa. Of the above, eight adult males have the wing-measurements as follows:--(1) $120 \mathrm{~mm}$; (1) 122 ; (3) 123 ; (1) 125 ; (2) 126.

In four adult females the wing-measurements are:-(1) $121 \mathrm{~mm}$; (2) 123 ; (1) 127. In the male type of G. purus Sharpe from Mount Elgon the wing measures $126 \mathrm{~mm}$.

In typical examples of $G$. casius from Cape Colony, \&c., the average measurement is about $127 \mathrm{~mm}$., i.e. about $2 \mathrm{~mm}$. more than in G. purus, and it appears absurr on that account to retain G. purus as a separate species. There is no difference in the colour of the plumage.

It has been stated by Dr. Sharpe (cf.' 'Ibis,' 1891, p. 121) that the white margins of the quills in $G_{\text {. }}^{\gamma}$ casius distinguish that species from $G$. purus, which has the external edges of the primaries slaty-grey like the back. But the fact is that the white edges 
to the quills are characteristic of the young birds of this species, which ranges from the mountains of Abyssinia to Cape Colony.

['The Grey Cuckoo-Shrike was not uncommon in the forest-zone of Ruwenzori from $6500 \mathrm{ft}$. to $8500 \mathrm{ft}$., but was never seen above or below that elevation. It had a very curious note, a long-drawn feeble squeak, such as one would expect a mouse or some very small bird to make; it resembled the note of a young Robin in autumn, but had almost less volume.-R. B. W.]

Graucalus azureus Cassin.

Coracina azurea Reich. Vög. Afr. ii. p. 516 (1903); Sharpe, Ibis, 1907, p. 457 [Cameroon].

a. 3. Irumu, Eturi Forest, $3000 \mathrm{ft} ., 17$ th Oct. [No. 3634. R. B. W.]

Iris dark claret; bill and feet black.

This specimen seems to be referable to $G$. azureus, but is somewhat larger than any of the West African examples in the British Museum. Wing 4.8 inches; tail $3 \cdot 8$.

[A single specimen of the Blue Cuckoo-Shrike was obtained in the Congo Forest, and was the only one seen. $-R . R . W$.

\section{Family MUSCICAPIDE.}

Melanornis Pamielana (Stanley).

Melaenornis pammelaina Reich. Vög. Afr. ii. p. 441 (1903).

Melcenornis pammelena Grant, Ibis, 1907, p. 592 [Baro River].

a-d. o . Mokia, S.E. Ruwenzori, 3400 ft., 21st-24th May. [Nos. 369. R. E. D.; 2377. G. L.; 3397, 3409. R. B.W.]

e-g. of et of imm. Mokia, S.E. Ruwenzori, $3400 \mathrm{ft} ., 16 \mathrm{th}$ June. [Nos. 462, 463, 4li8. R. E. D.]

Iris brown; bill and feet black.

The males are somewhat larger than the females.

c. Wing 3.75-3.9 inches.

?., 3.6

[Stanley's Cuckoo-Shrike was not uncommon in the acacia-country at the south end of Ruwenzori and in the Upper Semliki Valley, but was not seen on the range. It was breeding at the end of May. $-R . B . W$.]

Bradyoris murinus Finsch \& Hartl.

Bradornis pallidus murinus Reich. Vög. Afr. ii. p. 436 (1903).

Bradyornis murinus Grant, Ibis, 1908, p. 305 [N.W. of Lake Tanganyika].

a-d. of $q$ et + imm. Mokia, S.E. Ruwenzori, $3400 \mathrm{ft}$, 26th \& 27 th April. [Nos. 242, 243. R. E. D. ; 2292, 2295. G. L.]

Iris dark brown; bill and feet black. 
[A few examples of this Robin-Shrike were seen in the acacia-country at the sonth end of Ruwenzori in the middle of April. From the condition of the testes and ovaries in the specimens examined they did not appear to be breeding. The species was not subsequently met with.-R. B. W.

\section{Aisfonax pumluus Reichenow.}

Alseonax murinus pumilus Rcich. Vög. Afr. ii. p. 459 (1903).

$a-h$. of ot ot o imm. Mubuku Valley, E. Ruwenzori, 6000-7000 ft., 1st-26th Jan.

[Nos. 67, 76, 13.1. R. E. D. ; 2047, 2073, 2093. G. L. ; 3061, 3070. R. B.W.]

i-l. o. Mubuku Valley, E. Ruwenzori, 5500-10,000 ft., 21st-25th Feb. [Nos. 167,

175. R. E. D.; 1254.D.C.]

$m$ imm. Mubuku Valley, E. Ruwenzori, $5000 \mathrm{ft} ., 16$ th March. [No. 211. R. E. D.]

n. o . Mokia, S.E. Ruwenzori, $3400 \mathrm{ft} ., 4$ th May. [No. 3317. R. B. W.]

o. क imm. Butagu Valley, TV. Ruwenzori, $4000 \mathrm{ft}$., $30 \mathrm{th}$ July. [No. 2441. G. I..]

Iris dark brown; bill dark brown or blackish, lighter towards the base of the lower mandible; feet brown.

This bird seems to differ from typical A. murinus Fisch. \& Reich., which was described from the Meru Mountains, Massai, in having a paler abdomen, but in this respect some Abyssinian examples appear to be indistinguishable.

This small brown Flycatcher was found on Ruwenzori from an altitude of 5000 to $10,000 \mathrm{ft}$. It frequented chiefly the more rough open country among the cultivated patches below the forest-line, and was generally to be seen perched on a post or on the end of a dead bounh, from which it could easily fly after passing insects.R. I. W.

\section{Aldeonat infulatus (Hartl.).}

Alsconax infulatus Reich. Vögr. Afr. ii. p. $45 z$ (1903).

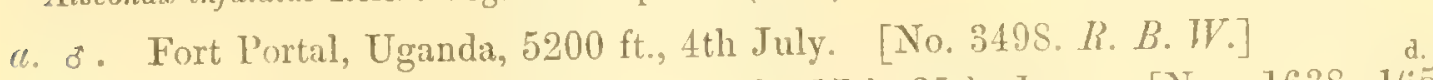

$b-f$. o Mokia, S.E. Ruwenzori, $3400 \mathrm{ft} ., 17$ th-25th Jume. [Nos. 1638, 1652, $1685,1686,1687$. D. C. $]$

Iris dark brown; bill and feet black.

This species is new to the British Museum Collection. All the specimens which have been named A. pumilus in the Jackson Collection are really referable to the above.

[Hartlaub's Brown Flycatcher was met with only in the papyrus-swamps and among the tall reed-beds along the shores of the lakes.-K. $B . W$. 


\section{Alseonat efulatus (Cassin).}

Alseonax epulatus Reich. Vög. Afr. ii. p. 455 (1903); Sharpe, lbis, 1907, p. 445 [Cameroon].

$a, b$. o et ơ imm. 30-40 miles N.W. of Fort Beni, Semliki Valley, $3000 \mathrm{ft}$., 12 th \& 13th Aug. [Nos. 3545, 3546.R.B. W.]

Iris dark brown; bill brown; feet yellow (adult male), light brown (immature male).

The immature male (No. 3546) has the secondary-quills, flanks, and upper tailcoverts tipped with sandy-buff.

In the British Museum there is a typical example of this species from Muni River, Giaboon (Du Chaillu).

[The small Slate-coloured Flycatcher was plentiful in the Eturi Forest, but was not seen in the Mpanga Forest east of Ruwenzori, although A. comitatus was found in both. It seemed to frequent the lower parts of the tall trees, especially where there was little undergrowth. $-R . B . W$.]

\section{Alseonat Fantisiensis Sharpe.}

Alseona.c fantisiensis Sharpe, Cat. Birds B. M. iv. p. 131 (1879) [Fantee].

Alsemax cpulatus antisiensis Rcich. Vög. Afr. ii. p. 456 (1903).

a. ․ . 40 miles N.W. of Fort Beni, 3000 ft., 13th Aug. [No. 3547. R. B. Wr.]

Iris dark brown; bill brown; feet black.

It is remarkable that this female example should hare been shot by Mr. Woosnam at the same spot where he obtained a young male of $A$. epulatus; but there seems to he no room for doubt that this bird is the true $A$. fantisiensis, as is shown by the ashy-grey colour of the upperparts and breast and by its bluck legs.

Alseorax comitatus (Cassin).

Pedilorlynchus comitatus Reich. Vög. Afr. ii. p. 461 (1908).

l'edilorhynchus stuhlmanni Reich. t. c. p. 160.

Pedilorhynchus stuhlmanni camerunensis Reich. t. c. p. 461.

Pedilorhynchus camerunensis Sharpe, 1bis, 190\%, p. 447 [Cameroon].

a. o. Mpanga Forest, Fort Portal, $5000 \mathrm{ft}$. 20 th Sept. [No. 518. R. E. D.]

b. o. Fort Beni, Semliki Valley, $3000 \mathrm{ft}$, 23rd July. [No. 3512. R. B.W.]

Dr. Reichenow has separated the Uganda and Cameroon birds under the above? headings, but I am unable to see any difference whatever between the above-mentioned specimens and the series sent home by Mr. Bates. All are referable to Butalis comitatus Cassin (P. Ac. Philad. 1857, p. 35), of which the Lititish Miseum contains typical examples collected by Du Chaillu in Gaboon.

The wing-measurement $(60 \mathrm{~mm}$.), as given by Dr. Reichenow in his key to the species, is misleading. Cassin perfectly correctly gives the wing-measurement of the type of $B$. comitutus as $2 \frac{1}{2}$ inches, which is equal to $63 \mathrm{~mm}$. 
This bird looks like a large specimen of $A$. epulatus, which was also procured at Fort Beni.

[Stuhlmann's Flycatcher was numerous in the Lturi Forest and also in the Mpanga Forest. Like A. epulatus it was always seen about the lower parts of the trees where there were open spaces to pursue insects, and was never observed among the dense undergrowth nor in the tree-tops.- $R . B . M Y$.

\section{Stizorinva vulpina Reichenow.}

Stizorhina vulpina leich. Vüg. Afr. ii. p. 467 (1903) ; Grant, Ibis, 1308, p. 305 [Ponthierville, Upper Congo].

a. ․ 10 miles N. of Fort Beni, Semliki, Valley, $3000 \mathrm{ft}$, 10th Aug. [No. 1771. D. C.]

b. ․ Irumu, Eturi Forest, $3000 \mathrm{ft} ., 16$ th Oct. [No. 362S. R. B.W.]

c. o. Mawambi, E. Congo Forest, $2500 \mathrm{ft}$., 31 st Oct. [No.580. R. E. I.]

Iris dark brown; bill blackish; feet brown or light brown.

'The differences between this species and $S$. fraseri have already been pointed out in my paper on Mr. Carruthers' collection from the Upper Congo, \&c.

In the present specimens the wing-measurements vary from $3 \cdot 65-3 \cdot 8$ inches.

[A few examples of this Chestnut Flycatcher were seen in the Congo Forest throughout the journey from Irumu to Basoko.- $R . B . W$.]

\section{Muscicapa toruexsis Hartert.}

Muscicapa toruensis Hartert, Nov. Zool. vii. p. 37 (1900) [Toro].

Alseonax toruensis Reich. Vög. Afr. ii. p. 453 (1903).

a. ơ. Mubuku Valley, E. Ruwenzori, $6000 \mathrm{ft} ., 28$ th Dec. [No. 2034. G. L.]

b-h. 우. Mubuku Valley, L. Ruwenzori, $6000 \mathrm{ft}$. 5th-28th Jan. [Nos. 74. R.E. D.; 1174.D.C.; 2086, 2119. G. L.; 3067, 3071, 3075. R. B.W.]

$i, k$. o. Mubuku Valley, E. Ruwenzori, 5000-6000 ft., 5th \& 17th March. [Nos. 1ST, 209. R.E. D.]

Iris chocolate or dark brown; bill bluish-grey, black towards the tip; feet very dark brown or black.

One male example of the Toro Grey Flycatcher (No. 74) has the middle of the breast and belly grey like the sides, whereas most of the specimens incline to whitish on the middle of the belly.

[The Toro Flycatcher was found on Ruwenzori only below the forest-line; it was not a common bird.- - R. B. W.] 
Tarsigtir rutenzori Grant. (Plate XVIII. fig. 4, o* ; Plate XIX. fig. 19, egg.)

Pogonocichla orientalis Jackson (nec Fischer \& Reich.), Ibis, 1906, p. 534 [Ruwenzori].

Tarsiger ruwenzori Grant, Bull. B. O. C. xix. p. 33 (1906) [Ruwenzori] ; id. Ibis, 1908, p. 307 [Mufumbiro Volcanoes].

Tarsiger eurydesmus Reich. Orn. Monatsb. xvi. no. 3, p. 48 (1908).

$a-l$. o $q$ et o $q$ imm. Mubuku Valley, Eastern Ruwenzori, 6000-11,500 ft., 3rdd.

31st Jan. [Nos. 1090, 1097, 1122, 1127. D. C.; 2062, 2068, 2069, 2127. G. I. ; 3103, 3114, 3141. R. B.W.]

$m, n$. o et imm. Mubuku Valley, 7000-10,000 ft., 2nd \& 24th Feb. [Nos. $213 \mathrm{~S}$. G. L. ; 3178. R. B.W.]

o. o imm. Mubuku Valley, $6000 \mathrm{ft}$., 5th March. [No. 188. R. E. D.]

This species is most nearly allied to T. johnstoni Shelley, which it resembles in having the outer webs of the secondary-quills margined with olive; but it is easily distinguished by the conspicuous orange-yellow rump and upper tail-coverts, and by having the yellow on the second pair of tail-feathers confined to the basal half of the outer web, and the outer pairs widely tipped with black, about 0.7 inch in width.

Iris dark hazel; bill black; feet olive-brown or greenish-brown.

o. Total length ca. $6 \cdot 0$ inches; wing $3 \cdot 2$; tail $2 \cdot 7$; tarsus $1 \cdot 0$.

․ $\quad$ " $\quad 5.6 \quad$;, $2.9-3.0$; tail 2.4 ; tarsus 0.95 .

Specimen No. 3141, a male shot by Mr. Woosnam at 11,500 ft., is a very richly. coloured bird, the mantle and back being of a more reddish-olive colour than in any other specimen, and the breast and sides of a deeper orange-yellow.

Immature birds of this species have the head, mantle, chest, and breast spotted, the feathers of the upperparts having a buff spot margined with black at the extremity, while those of the underparts are pale yellow bordered with black. The belly is pale yellowish-white. The outer tail-feathers are quite differently marked from those of the adult, being orange-yellow, bordered on both webs at the extremity with black, whereas in the adult the whole terminal portion of the feather is black.

Mr. Carruthers obtained an adult male example of this species on the Mufumbiro volcanoes.

Dr. Reichenow has recently re-described this species under the name of Tarsige euryilesmus.

'Iwo eggs of T. ruwenzori were procured in the Mubuku Valley, at an elevation of $8000 \mathrm{ft}$., on the 23rd of January. 'They are of a rather pointed oval shape and slightly glossy. 'The ground-colom is white, finely freckled all over with light red and lilacgrey, the markings being most numerous towards the larger end. They measure $.94 \times \cdot 61 ; \cdot 9 \times \cdot 62$ inch.

['The Ruwenzori Bush-Robin was met with from an altitude of $6500 \mathrm{ft}$. up to $12,000 \mathrm{ft}$. It was most numerous in the forest and in the lower part of the 
bamboo. It frequented the undergrowth only, and was never seen in the trees.R. B.W.]

\section{Parisoma plumbeum (Tartl.).}

Parisoma plumbeum Reich. Vög. Afr. iii. p. 521 (1905); Grant, Ibis, 1908, p. 307 (Ponthierville, Upper Congo].

a, b. ot of imm. Mokia, S.E. Ruwenzori, $3400 \mathrm{ft}$. , 3rd May. [Nos. 276, 277. R. E. D.]

c, d. of f. Fort Beni, Semliki Valley, 3000 ft., 23rd July. [Nos. 1749, 1701. 1). C.]

e. ․ Fort Beni, Semliki Valley, $3000 \mathrm{ft}$, 9th Aug. [No. 3537. R. B.W.]

Iris dark brown; bill black or dark grey; feet dark grey or bluish-black.

A young male (No. 277) is in much the same stage of plumage as the bird described from Mr. Carruthers' collection in my paper quoted above. The female (No. 1751), one of the pair shot on the 23rd of July, is in very worn plumage, the grey feathers on the upperparts inclining to sandy-brown.

[A few examples of Hartlaub's 'Tit-Warbler were seen on the plains at the southeast end of Ruwenzori, and in the open clearings in the Eturi Forest, also near Fort Portal, but they were everywhere rather scarce. $-R . B . W$.

\section{Chloropeta kenya Sharpe.}

Chloropeta icterina Sharpe (nec Sundev.), P. Z. S. 1900, p. 608 [Mt. Kenya, 10,000 ft.].

Chloropeta kenya Sharpe, Bull. B. O. C. xii. p. 35 (1901) [Mt. Kenya, 10,000 ft.].

Chloropeta natalensis kenya Reich. Vüg. Afr. ii. p. 465 (1903).

a-c. ১. Mubuku Valley, E. Ruwenzori, 6000-10,000 ft., 16th-31st Jan. [Nos. 134. R. E. D.; 1206. D. C.; 2088. G. L.]

d. ㅇ. Mubuku Valley, E. Ruwenzori, $7000 \mathrm{ft} ., 3 \mathrm{rd} \mathrm{Feb.} \mathrm{[No.} \mathrm{143.} \mathrm{R.} \mathrm{E.} \mathrm{D.]}$

$e-h$. $\delta^{*}$ o et $\sigma^{*} \mathrm{imm}$. Mubuku Valley, E. Ruwenzori, 6000-8000 ft., 4th-23rd March. [Nos. 1287, 1411. D. C.; 2213, 2214.G. L.]

i. q. Mubuku Valley, E. Ruwenzori, $9000 \mathrm{ft}, 12 \mathrm{th}$ April. [No.3271. R. B. W.]

k. o*. Butagu Valley, W. Ruwenzori, $7000 \mathrm{ft}$., Ist Aug. [No. 1761. D. C.]

Iris hazel or dark brown; bill blackish, lower mandible mostly yellowish-horncolour; feet grey or greenish-grey.

'The only difference between this species and $C$. similis Richmond [cf. 'Auk,' xiv. p. $163(1897)$, which was obtained on Kilimanjaro at an altitude of $10,000 \mathrm{ft}$, appears to be one of size, the wing-measurement being somewhat smaller, $2 \cdot 15$ inches. I may here remark that Dr. Reichenow seems to have omitted all reference to C. similis (cf: Vög. Afr. ii. p. 464), while Mr. Oberholser has identified it with $C$. Kenya [cf. Pr. U.S. Nat. Mus. xxviii. p. 912 (1905)]. I doubt the correctness of this identification for the 
reason given above, and also because in the original description of $C$. similis the sides of the face and ear-coverts are said to be of the same brownish-green colour as the upperparts, whereas in C. kenya those parts are washed with yellow. It will be necessary to compare typical examples of both forms before a definite conclusion can be arrived at. The shape of the wing varies in different individuals, and too much reliance cannot be placed on it. In the present series the 3rd primary-quill is sometimes equal in length to the 8 th and sometimes to the 9th quill.

Immature birds (Nos. 1287 \& 2213) differ from the adults in having the upperparts brownish-olive instead of dark greenish-olive, and the underparts paler yellow, the chest and flanks being tinged with cinnamon.

\section{C. kenya.}

1 o (type of the species). Kenya. Wing $2 \cdot 3$ inches.

23 . Kikuyu Lscarpment. Wing $2: 35$ and $2 \cdot 45$ inches.

5 万. E. Ruwenzori. Wing $2 \cdot 3-2 \cdot 45$ inches.

3 f. $\quad$ " $2 \cdot 25-2 \cdot 3$ inches.

C. similis.

1 o (type of the species). Kilimanjaro. Wing $2 \cdot 15$ inches.

[The Kenya Yellow Flycatcher was met with on Ruwenzori from an altitude of 7000 to $10,000 \mathrm{ft}$. It was most plentiful in the swampy parts of the valleys from 9000 to $10,000 \mathrm{ft}$., usually keeping to the dense undergrowth. It has a short and very low but extremely musical song, which is most often to be heard late in the evening. R. B. $W$.

Cinloropeta massaica Fischer \& Reichenow.

Chloropeta natalensis massaica Reich. Vög. Afr. ii. p. 465 (1903).

Chloropeta natalensis umbriniceps Neumam; Reich. t. c. p. 465.

Chloropeta massaica Jackson, Ibis, 1901, p. 91 [Nandi]; Grant, Bull. B. O. C. six. p. 32 (1906); id. Ihis, ]903, p. 307 [Lake Kivu].

a. o $1 \mathrm{~mm}$. 140 miles W. of Kntebbe, $4200 \mathrm{ft} ., 10 \mathrm{th}$ Dec. [No. 1054. D. C.]

b. f. Mpanga Forest, Fort Portal, 5000 ft., 21st Sept. [No.551. R. E. L.]

c. ․ Mubuku Valley, E. Ruwenzori, $6000 \mathrm{ft}$, 18th March. [No. 13371. D. C.]

d. ․ Butagu Valley, W. Ruwenzori, $4000 \mathrm{ft}$., 28th July. [No. 2438. G. L.]

€. . 60 miles N. of Fort Beni, Semliki Valley, $3500 \mathrm{ft} ., 16$ th Aug. [No. 17 S6. I). C.]

Iris dark hazel; upper mandible black, lower brown; feet varying from dark grey to blackish.

A quite young bird (No. 1054) has the upperparts browner than in the adult, the pale edges of the quills much wider and of a rufous-yellow colour, and the underparts, especially the chest, sides, and flanks, washed with cinnamon-buff. 
[The Massai Yellow Flycatcher was observed near Entebbe, all around Ruwenzori, and in the Semliki Valley near Fort Beni. On Ruwenzori it was found up to an elevation of 6000 feet, but not higher: at 7000 feet a very similar species, C. kenyn, takes its place and ranges up to 10,000 feet. Its favourite haunts are low-lying damp places and valleys, where there are tall grasses or reeds and dense undergrowth.R. B. W.

\section{Chloropeta gracilirostris Grant. (Plate XVIII. fig. 3, o .)}

Chloropeta gracilirostris Grant, Bull. B. O. C. xix. p. 33 (1906).

a. o imm. Mokia, S.E. Ruwenzori, $3400 \mathrm{ft}$, 12th June. [No. 1623. D. C. Type of the species.]

This apparently immature bird differs from all known species of Chloropeta in having a longer and more slender bill and the feet and claws greatly developed. The latter peculiarity is well shown in the accompanying text-figure 13 , in which the

Text-fig. 13.

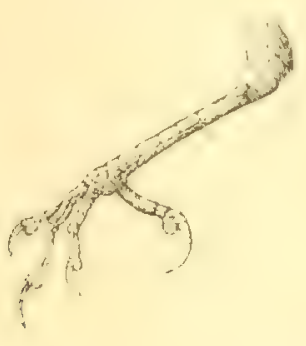

1.

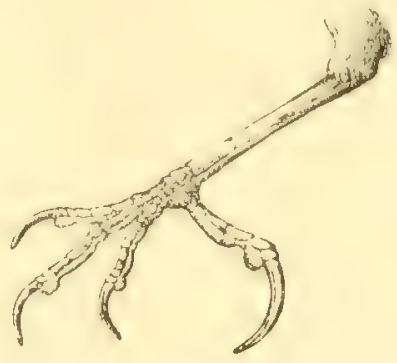

2.

1. Foot of Chloropeta kenya Sharpe.

2 , " gracilirostris Grant.

foot of $C$.gracitirostris is compared with that of $C$. kenya, a species of about the same size as regards the wing-measurement. It is most nearly allied to $C$. kenya Sharpe, from which it differs principally in its somewhat darker olive upperparts and in the absence of a superciliary stripe. The type-specimen has the edges of the flight-and tail-feathers as well as the upper tail-coverts dull reddish-brown, and the lower back, sides, and flanks washed with the same colour.

Iris dark reddish-brown; bill brown; feet black.

Total length about 5.4 inches; culmen 0.63 , width at the base of the nostrils 0.2 ; wing 2.5 ; tail 2.4 ; tarsus 1.0 .

[A few of these Flycatchers were found inhabiting the dense papyrus-swamps and reed-beds along the shores of Lake Albert. They were apparently rather uncommon, but the difficulty of seeing birds which live in such situations may have misled us in this respect. $-R \cdot B . W$. 
Batis orientalis (Heugl.).

Batis orientalis Reich. Vög. Afr. ii. p. 481 (1903).

a, b. o f. 100 miles W. of Entebbe, $4000 \mathrm{ft}$., 4th \& 5th Dec. [Nos. 27. R. E. D.; 3029. R. B. W.]

$c-g . \delta$ of et imm. Mokia, S.E. Ruwenzori, $3400 \mathrm{ft} ., 4$ th-23rd May. [Nos. 1521, 1608. D. C.; 3315, 3362, 3363. R. B.W.]

h. o. Mokia, S.E. Ruwenzori, $3400 \mathrm{ft}$, 6th June. [No. 3458. R. B.W.]

i. o* Lower Semliki Valley, $2500 \mathrm{ft}$. , 4th Oct. [No. 3626. R. B.W.]

Iris yellow; bill and feet black.

[Heuglin's White-flanked Flycatcher was obtained near Entebbe and in the acaciacountry at the north and south ends of Ruwenzori, but it was never met with on the mountains above $5000 \mathrm{ft} .-R . B . W$.

Batis pukla Reichenow.

Batis puella Reich. Vög. Afr. ii. p. 483 (1903).

a-e. of . . Mubuku Valley, E. Ruwenzori, 6000-8000 ft., 2nd-31st Jan. [Nos. 1128. D.C.; 2048, 2049, 2070, 2130.G.L.]

Iris bright yellow or greenish-yellow; bill and feet black.

[The Sylph-like Flycatcher was found on Ruwenzori from an altitude of 6000 to $8000 \mathrm{ft}$., usually below the forest-line. It was breeding in January, $-R . B . W$.]

\section{BATIS DIOPS Jackson. (Plate XVIII. fig. 2, ơ.)}

Batis diops Jackson, Bull. B. O. C. xv. p. 38 (1905) [Ruwenzori]; Reich. Vög. Afr. iii.p. 831 (1905); Jackson, Ibis, 1906, p. 535 [Ruwenzori].

a-0. o ㅇ․ Mubuku Valley, E. Ruwenzori, 6000-8000 ft., 4th-20th Jan. [Nos. d. $102,104,119 . R . E . D . ; 1100,1108,1144 . D . C . ; 3069,3080,3101,3106,3107$, $3108,3109,3116 . R . B . W$.

p. o. North Rurenzori, $7700 \mathrm{ft.}, 28$ th Sept. [No.560. R. E. D.]

Iris yellow or orange; bill and feet black.

It is remarkable that in this species the sexes are perfectly similar in plumage.

[Jackson's Pied Flycatcher frequented the forest-zone from 6500 to $8500 \mathrm{ft}$., where it was very numerous. It was to be found among the dense undergrowth and also frequented high trees. $-R . B . W$.]

\section{Diapionophyia castanea (Fraser).}

Diaphorophyia castanea Reich. Vög. Afr. ii. p. 490 (1903); Sharpe, Ibis, 1907, p. 448

[Cameroon]; Grant, Ibis, 1908, p. 306 [Kasongo and Ponthierville, Upper Congo].

Diaphorophyia leucopygialis Fraser; Jacksun, Ibis, 1906, p. 535 [Toro]. 
$a-d$. o ․ . Mpanga Forest, Fort Portal, $5000 \mathrm{ft}$., 18th-20th Sept. $\quad[$ Nos. $545,546$. R. E. D.; 3577, 3578. R. B.W.]

e,f. $\delta$ ․ Fort Beni, Semliki Valley, 3000 ft., 21st \& 23rd July. [Nos. 493. R. E. D.; 1731. D.C.]

Iris plum-colour or mauve, wattle round the eye dark mauve; bill black; feet mauve.

Mr. Bates has published some interesting notes on the habits of this species ( $c f$. 'Ibis,' 1905, p. 94).

[A few examples of Fraser's Spectacled Flycatcher were seen in the Mpanga and Eturi Forests, but they were rather uncommon. They frequented the undergrowth and were never seen high up in the trees. $-R . B . W$.

DinpHorophyia JAMESONi Sharpe.

Diaphorophyia jamesoni Reich. Vüg. Afr, ii.p. 493 (1903).

$a-g . \delta^{*} q$ et $\sigma^{*} \mathrm{imm}$. Mpanga Forest, Fort Portal, $5000 \mathrm{ft}$, 15̆th-23rd Sept. [Nos. $518,540,555 . R . E . D . ; 3572,3573,3579,3580 . R . B . W$.

h, i. $\delta^{*}$. Fort Beni, Semliki Valley, $3000 \mathrm{ft.}$,20th \& 24th July. [Nos. 1728, 1753. D.C.]

Iris dark brown; eyelid turquoise-blue; bill black; feet mauve.

The female has the crown and the upperparts greyer than in the male, and with less oil-green gloss.

Quite joung males have the upperparts like those of the female, but with even less greenish gloss. 'The chin, throat, and upper chest are chestnut, darker on the sides, and bordered posteriorly with a blackish band, and a few deep green feathers of the adult plumage are mingled with the chestnut feathers of the throat.

[Jameson's Spectacled Flycatcher was met with throughout the journey through the Congo Forest from Irumu to Basoko. It was also found in the Mpanga Forest east of Ruwenzori. It inhabits the darkest parts of the forest, where it usually frequents the tall undergrowth and is never seen high up in the trees. $-R . B . W$.

Platystira cranea (P. L. S. Müller).

Platysteira cyanea Reich. Vüg. Afr. ii.p. 488 (1903); Sharpc, Ibis, 1907, p. 449 [Cameroon]. Platystira albifrons Sharpe, Ibis, 1873, p. 159 [River Loge].

Platysteira cyanea albifrons Reich. t. c. p. 489.

Platysteira cyanea nyansa Neumann, J. f. O. 1905, p. 210.

a. ㅇ. Mokia, S.E. Ruwenzori, $3400 \mathrm{ft}, 29$ th April. [No. 3293.R.B. H.]

b, c. o f. Mokia, S.E. Ruwenzori, $3400 \mathrm{ft}$. , 2nd \& 22nd May. [Nos.383. R. E. I).; $1479.2 . C$. 
d-f. of $q$. Mokia, S.E. Ruwenzori, $3400 \mathrm{ft}, 11$ th \& 15 th June. [Nos. 3165, 347S, 3485. R. B. W.]

g- $k$. of et $\sigma^{\circ} \mathrm{imm}$. Fort Beni, Semliki Valley, $3000 \mathrm{ft}$., 21st-24th July. [Nos. 1732 , 1755, 1758. D. C. ; 3515.R. B.W.]

l. o imm. Butagu Valley, W. Ruwenzori, $4000 \mathrm{ft}$., 30th July. [No. 2443. G. L.]

Iris grey or dark grey; eye-wattle scarlet; bill and feet black.

$P$. albifrons Sharpe appears to be founded on somewhat immature male examples of $P$. cyanea. In the present collection there are males both with and without the white forehead, shot at Mokia, S.E. Ruwenzori, and from Fort Beni there are males clearly showing a transitional stage, in which the white band on the forehead is only represented by a few white feathers.

Professor Neumann has recognized four subspecies of $P$. cyanea, but the differences by which he characterises them seem to be of no value.

[These small Flycatchers were met with here and there all round the eastern and south-eastern base of Ruwenzori as well as at Fort Beni on the edge of the Congo l'orest. Their note is a curious one, somewhat similar to that of Batis orientrlis Heugl., which consists of two low clear whistled notes, descending and with a considerable interval between them. $P$. cyanea utters two very similar notes, but adds a third and lower note the same number of semitones below the second that the second is below the first. $-R . B . W$.]

\section{Megabias equatorialis Jackson.}

Megabias aquatorialis Jackson, Bull. B. O.C. xv. p. 11 (1904) [Entebbe and Toro]; id. Ibis, 1906 , p. 536 ['T'oro].

Megabias atrialatus aquatorialis Reich. Vög. Afr. iii. p. 831 (1905).

\%. ㅇ. Mpanga Forest, Fort Portal, 5000 ft., 17 th Sept. [No. 523. R. E. D.]

Iris crimson; bill black; feet flesh-colour.

In this species the female has all the tail-feathers, except the outer pair, blackish narrowly margined with chestnut, whereas in the allied M. atrialatus Cassin all the tail-feathers are chestnut. 'The males are practically indistinguishable.

Only one specimen was seen.

\section{Suttionis CaMerunexsis Sharpe.}

Smithornis camerunensis Sharpe, Ibis, 1905, p. 469 [ + only, River Ja, S. Cameroon]; id. Ibis, 1908, p. $45 \mathrm{l}$ [River Ja].

a. ․ . Mpanga Forest, Fort Portal, $5000 \mathrm{ft} ., 18$ th Sept. [No. 3576. R. B. W.]

Iris dark brown; upper mandible black, lower white; feet light greenish-yellow.

A great deal of confusion has taken place over this species, which is nearly allied to $S$. capensis Smith, but is somewhat smaller and has a much darker and more richly 
coloured brown back, \&c. The sexes are similar in plumage in fully adult birds. The type-specimen of $S$. camerunensis is a female. Dr. Sharpe made the mistake of referring male examples of S. rufolateralis G. R. Gray from S. Cameroon to this species (cf.' 'Ibis,' 1905, p. 469); but on my pointing out this mistake to him it was subsequently corrected (cf.' 'Ibis,' 1908, p. 451). Mr. Bates had now procured a number of males of $S$. camerunensis as well as females, and these do not differ in any way from the type, except that the latter has the crown somewhat streaked, not uniform as in the ardult male and in the most adult females. The female specimen from Mpanga is likewise perfectly similar to the type, both the wings and tail being precisely the same length-wing 2.5 inches; tail 1.9 . The specimen is evidently a very mature bird, with the crown black like that of the male, the margins of the median wing-coverts whitish instead of rufous-buff, and the under tail-coverts with very narrow dark shaft-streaks. Among $M[r$. Bates's birds there is a similarly marked specimen (No. 1142) in very worn plumage, but the streaks on the under tail-coverts are wider as in other Camerom specimens. 'The sex of this bird was not ascertained. It may be that the Mpanga bird represents a slightly different form, but more material is required to settle the point.

[A few examples of the Cameroon Broad-billed Flycatcher were seen, or rather heard, in the Mpanga Forest, but they were by no means common. The note of this little bird is, I think, the most remarkable I have ever heard, and it is impossible to describe it satisfactorily. It is a kind of jarring noise, something like the sounc made by the Greater Spotted Woodpecker hammering upon a dead tree-trunk, but rery much louder and more resonant. I had often heard this sound in the forest, but for a long time could not discover the cause of it. The natives said it was made by a Colobus Monkey, but at last I had twice the good fortune to watch the bird actually making the noise, at a distance of 15 yards from me. Had I not seen and heard it so close to me, nothing would have persuaded me to believe that it was not produced by a large animal. It was just the sound one would expect a large Hornbill, such as Bycanistes subcylindrious, to make. The bird was perched on the end of a short broken bough, but it did not utter the sound from there. At short intervals it flew suddenly up and hovered like a great hawk-moth by the trunk of the tree with its beak almost touching the bark, and in this position gave forth the extraordinary jarring note. I watched it do this twice in a minute in exactly the same spot, and then, fearing it might escape, I shot it. The native who had told me it was a Colobus was with me and seemed as much surprised as I was. I have since wondered whether the sound is for the purpose of frightening insects out of the bark or moss. Both S. camerunensis and S. rufolateralis make this curious sound. $-R . l i .[H$. 
Simthornis rufolateralis G. R. Gray.

Smithornis rufolateralis Reich. Vüg. Afr. ii. p. 4 z1 (1903); Sharpe, Ibis, 1907, p. 45..

Smithornis camérunensis Sharpe, Ibis, 1905, p. 469 [ o, no. 456, Efulen, Cameroon].

a. 3. Mawambi, E. Congo Forest, $2500 \mathrm{ft}$, 30th Oct. [No. 3647. R. B. W.]

A male of this species procured in the Bugoma Forest, Unyoro, was presented to the British Museum by Dr. C. Christy.

[Gray's Broad-billed Flycatcher was met with throughout the journey through the Congo Forest, but was not very numerous. It inhabits the darkest parts of the forest where the trees are tallest, but does not frequent the trec-tops. Its note is exactly the same as that of $S$. cameruensis Sharpe. $-R . B . W$.

SMitionnis siarpei Alexander.

Smithornis sharpei Alexander, Bull. B. O. C. xiii.p. 31. (1902) [Fernando Po]; id. Ibis, 1903, p. 384 , pl. vii.

Smithornis zenkeri Reich. Orn. Monatsb. xi. p. 41 (1903); id. Vüg. Afr. ii. 1. Fist (190:3); Bates, Ibis, 1905, p. 95; Sharpe, Ibis, 1907, p. 452 [S. Cameroon].

a. o imm.? 20 miles N. of Fort Beni, Semliki Valley, 3000 ft, 11th Aug. 1. 1.. $177 \%$. [. C.:

Iris dark hazel; bill black, lower mandible whitish; feet pale green.

The description of the bird from Fernando Po was published by Mr. Boyd Alexander on the 23rd of December, 1902, while Dr. Reichenow's description of S. zenkeri did not appear till 1903, consequently the former name has priority. I have compared examples from Fernando Po with Cameroon specimens and they atppear to be perfectly similar.

Mr. Alexander ('Ibis,' 1903, p. 385) has expressed the opinion that S. zenkeri differs from $S$. sharpei, but with the material now available for comparison I cannot see that this is really the case.

The specimen in the present collection does not appear to be fully mature: the bill is less broad than in Cameroon birds in the British Museum; the wing-coverts are more conspicuously edged with rufous; and the white patch on the throat is tinged with yellow. All these characters are probably signs of immaturity.

Mr. Bates, in his paper quoted abore, gives some interesting notes on the habits of this species. He mentions the loud rattling noise made by the male, his remarks bearing out what Mr. Woosnam has written above of $S$. camerunensis and S. rufolateralis.

Artomias fuliginosa Verr.

Arlomynas fulliginosa Reich. Vög. Afr. ii. p. 462 (1903); Sharpe, Ibis, 1907, p. 452 [Efulen, Cameroon].

a-c. o \&. Fort Beni, Semliki Talley, $3000 \mathrm{ft}, 23 \mathrm{rd} \&$ 24th July. [Nos. 2436. G. L. ; 3519, 3520. R. B.W.] 
d. ․ 40 miles N.WV of Fort Beni, $3000 \mathrm{ft}$, 13th Aug. [No. 2450. G. L.]

e. 3. Mipanga Forest, Fort Portal, 5000 ft., 17th Sept. [No. 524.R. E. D.]

Iris dark brown; bill black; feet clark brown.

[Verreaux's Dusky Flycatcher was plentiful in both the Lturi and Mpanga Forests. It was generally to be seen perched high up at the end of a dead bough, from which it made short flights after passing insects, always returning to the same tree; sometimes six or eight might be seen on a single dead tree, but they were more often observed in pairs. When flying they might be easily mistaken for Martins. $-R . B . W$.]

Erythlocercus congicus Grant. (Plate XIV. fig. 1, o.)

Erythrocercus congicus Grant, Bull. B. O. C. xix. p. 41 (190\%).

a. ơ. Irumu, Eturi Forest, $3000 \mathrm{ft}$, 16th Oct. [No. 566. R. E. I). Type of the species.]

This species is most nearly allied to $E$. maccalli (Cassin), but the top of the head is deep chestnut instead of bright chestnut-red.

Iris pink; bill brown; feet flesh-colour.

'lotal length ca. $3 \cdot 8$ inches; wing 2.0 ; tail 1.75 ; tareus 0.65 .

Mr. R. E. Dent procured a single example of this beautiful little Flycatcher.

'Trochocercus albonotatus Sharpe.

Trochocercus albonotatus Sharpe, Ibis, 1891, p. 121 [Mt. Elgon]; Reich. Vög. Afr. ii. p. 499) (1903); Jackson, Ibis, 1906, p. 536 [Ruwenzori].

a-i. o ㅇ․ Mubuku Valley, E. Ruwenzori, 5000-8500 ft., 2nd-16th Jan. [Nos. S5. R. E. D. ; 1086, 1087, 1158. D. C. ; 2051, 2060, 2061. G. L.; 3082, 3121. R. B.W.]

k. ․ Mubuku Valley, E. Ruwenzori, $6000 \mathrm{ft}$., 3rd Feb. [No. 1215. D. C.]

l-p.o + . " " 7000-8000 ft., 4th-24th March. [Nos. 1290, d. $291,1368,1416$. D. C. ; 3244. R. B. W.

Iris dark brown; bill black; feet dark brown or black.

['This pretty little Flycatcher was one of the most numerous birds inhabiting the forests on Ruwenzori and was confined to that zone. It was occasionally to be seen among the lower parts of the bamboo up to an altitude of $8500 \mathrm{ft}$., but it was never seen below $6500 \mathrm{ft} .-R . B . W$.

'Trochocercus bedfordi Grant. (Plate XVIII. fig. 1, $0^{*}$.)

Trochocercus belfordi Grant, Bull. B. O. C. xix. p. 40 (1907).

a, b. of f. Mawambi, E. Congo Forest, $3000 \mathrm{ft.}, 17 \mathrm{th}$ Oct. [Nos. $36331,363 \mathrm{z}$. R. B.W. Types of the species.]

'This species is most nearly allied to $T$. nitens Cass., but is larger; the general colour $: ; 11 \ddot{-1}$ 
of the plumage is of a bluer-grey; the crest shorter; and the clges of the wingfeathers margined with blue.

6. Iris dark brown; bill and feet slate-blue.

ㅇ. Iris dark brown; bill dark horn-colour; feet slate-blue.

0 . 'Total length ca. $6 \cdot 5$ inches; wing 3.0 ; tail $3 \cdot 2$; tarsus 0.6 .

․ $\quad, \quad 6.3, \quad ; \quad, 2.9 ; \quad, 2.8 ; \quad, \quad 0.6$.

An allied species, T. Tibatiensio, has recently been described by Mr. Alexander from the Kibali River [cf: Bull B. O. C. xix. p. 88 (1907)].

[The Duke of Bedford's Flycatcher was a common bird in the forest between Irumu and Mawambi. Its note exactly resembled that of Terpsiphone emini, and the two species might often be seen darting out from the same tree at passing insects. T. emini was also found in the Mpanga Forest, but T. bedfordi was met with only in the Eturi and Congo Forests. $-R . B . W . j$

Terpsiphone duchaillei Cassin.

Muscipeta duchaillui Cass. P. Ac. Plilad. 1859, p. 48 [Camma R., Gaboon].

Tchitrea viridis Reich. Vüg. Afr. ii. p. 504 (1903) [part.].

a. o*. Mokia, S.E. Ruwenzori, $3400 \mathrm{ft}$., 9 th June. [No.3461. R. R. IF.]

Iris dark brown; bill and feet light blue.

'This adult bird is in nearly black and white plumage, but some of the feathers of the back are partially chestnut; the five outer and shorter pairs of tail-feathers are white, more or less bordered with black and with black shafts.

'Terpsiphone suahelica Reichenow. (Plate XIX. fig. 13, egg.)

Tchitrea perspicillata suahelica Reich. Vüg. Afr. ii. p. 509 (1903).

a. 3. 80 miles W. of Entebbe, $3800 \mathrm{ft}$., 2nd Dec. [No.3021. R. B. W. ]

b. 3. Mokia, S.E. Ruwenzori, $3400 \mathrm{ft}, 28$ th April. [No. 1449. D. C.]

c-m. of o . Mokia, S.E. Ruwenzori, $3400 \mathrm{ft}$, 5th-2tth May. [Nos. 318, 341.

li. E. D.; 1504, 1553, 1569, 1585, 1609, 1611, 1620. D. C.; 2359. G. L.]

n-w. o ㅇ․ Mokia, S.E. Ruwenzori, $3400 \mathrm{ft}$., 1st-29th June. [Nos. 406, 413, 422, 401), 458.R.E. D.; 1667, 1670, 1711. D. C.; 3449, 3493. R. B. W.

x. ․ Fort Beni, Semliki Valley, $3000 \mathrm{ft.}$, 23rd July. [No. 3518. R. B. W.]

Great interest attaches to the changes of plumage in this species. Both Mr. Alexander and Prof. Neumann hare recently deroted much attention to a study of the series in the British Museum. In naming the specimens in the present collection I have followed the views of the former, with which I agree. All have the onter tail-feathers chestnut, with the exception of specimen No. 1553, in which some of the outer tailfeathers as well as the middle pair are mostly white. 'This specimen may be a hybrid with T. emini. 
A single egg of this spccies was procured at Mokia from a small nest placed in the fork of a low tree. The male bird was shot at the nest.

The egg is of a regular oval form and slightly glossy. The ground-colour is creamywhite with small light red and dark purplish-grey spots, which are mostly concentrated in a broad zone round the larger end. It measures $78 \times 58$ in.

[This Paradise-Flycatcher was very plentiful at the south end of Ruwenzori and in the Semliki Valley. It was also seen near Entebbe, but was not met with on the range. It was breeding at the end of April and also in June. $-R . B . W$.

\section{Terpsitione amini Reichenow.}

Tchitrea emini Reich. Vüg. Afr. ii. p. 512 (1903).

a. o. Mpanga Forest, Fort Portal, 5000 ft., 13th Sept. [No. 511. R. E. D.]

Iris dark biown; eyelids, bill, and feet blue.

'This male has a rather short chestnut-coloured tail, but in other respects appears to be an adult bird. Both the upper- and underparts are of a brilliant orange-chestnut, without any shade of brown. An immature male from 'Toro in Mr. Jackson's collection has the underparts partially covered with new feathers of a very similar orange-chestnut, but all other male specimens in that collection are of a much brownerclestnut colour.

The British Museum did not contain an example of the present species, only the clnsely allied T. rufiventris (Swains.) being represented. 'This latter resembles examples of T. emini in having the black occipital crest well developed, even longer, and glossed with steel-blue, while in the allied species 'T'. nigriceps (Hartl.) the feathers on the crown are much shorter and of a purplish-black colour. 'T' ruficentris, moreurer, is easily distinguished from T. emini by haring the feathers behind the eye as well as the ear-coverts chestnut instead of black, an important character which has hitherto been overlooked, though Swainson partially indicated it in his plate [cf. B. W. Afr. ii. p. ôs. pl.iv. (1837)]. A male of T. rufiventris in the British Museum (Gambia: Sharpe coll.) has the outer webs and tips of the greater and median wing-coverts as well as the otuter. margins of the innermost secondary-quills white. From this one may infer that the specimen in question is not in the fullest adult plumage.

In the Jackson Collection there is an adult male from Entebbe, shot on the 30 th of Nay, 1904, which appears to be a hybrid between $T$. emini and $T$. succhelice. It most nearly resembles $T$. emini, but some of the greater wing-coverts and secondaries are edged externally with white and the black of the throat is continued on to the upper breast, which is mixed with grey, while the rest of the underparts are bright chestnut. 'There is a somewhat similar specimen (No. 1553) in the present collection, which I have already referred to under the heading $T$. suahelico. 
Trapsiphone ignea Reichenow.

Tchitrea ignea Reich. Vög. Afr. ii. p. 512 (1903).

Terpsiphone ignea Dubois, Ann. Mus. Congo, i. fasc. i. p. 13, pl. vi. fig. 2 (1905).

a. \&. Fort Beni, Semliki Valley, $3000 \mathrm{ft} ., 9$ th Aug. [No. 1769. D. C.]

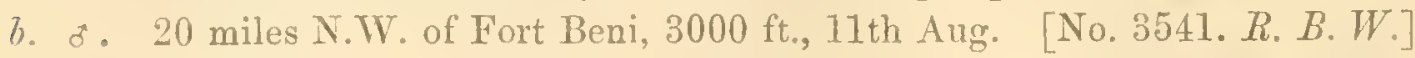

c. o. Mawambi, E. Congo Forest, $2500 \mathrm{ft}$, 31 st Oct. $\quad[N o .3650 . R . B . W$.]

Iris dark grey or dark brown; eyelids blue; bill bluish-grey.

The male differs from the male of T' nigriceps Hartl. in having the tail dark brown washed with rufous, instead of chestnut, and the black of the head extends over the nape, whereas in ' $T$ '. nigriceps it terminates on the occiput.

In neither of the male specimens is the tail fully grown, but the moulting-feathers are of the same reddish-brown colour as the old ones, and there is no reason to suppose that they will ever become bright chestnut.

The female differs from the female of $T$. nigriceps in having the crown and nape greyish-black, this colour extending even on to the upper mantle, where it becomes paler; the throat and sides of the head dark grey and the tail reddish-brown as in the male. Younger examples of $T$. nigriceps have the tail very similarly coloured; but the greyish-black head and throat of the female of the present species serve to distinguish it at a glance from $T$. nigriceps.

*. Total length (tail in moult) 7 inches; wing $3 \cdot 1$; tail $3 \cdot 5$; tarsus $0 \cdot 6$.

ㅇ. $, \quad, \quad 5.7$ inches; wing 2.8 ; tail 2.4 ; tarsus 0.6 .

I have little doubt that these birds have been correctly identified as T. ignea, a species originally described from Angola.

[This Brown-tailed Paradise-Flycatcher was not uncommon in the Congo Forest.R. B. H.]

Eiminia lojgicauda (Sivainson).

Elminia Tongicauda Reich. Vög. Afr. ii. p. 4.96 (1903); Bates, Ibis, 1205, p. 36 [Cameroon; hahits]; Jackson, Ihis, 1906, p. 537 [Toro]; Sharpe, Ibis, 1908, p. 457 [Cameroon].

a-c. o ㅇ. 100-150 miles W. of Entebbe, 4100-5000 ft., 4th-12th Dec. [Nos. 47. R. L. D.; 1030, 1055. D.C.]

d, e. o ㅇ. Mubuku Valley, E. Ruwenzori, $6000 \mathrm{ft}$., 26th Jan. [Nos. 129, 130. IT. L. D.]

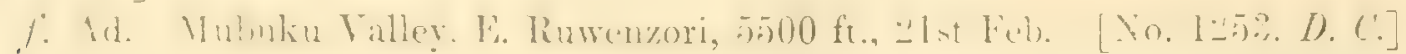

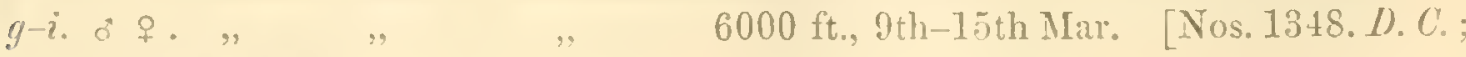
3187, 3183. R. B.W.]

l. o . Miokia, S.E. Ruwenzori, $3400 \mathrm{ft}, 23 \mathrm{rd}$ May. [No. 3403. R. B.W.]

Iris dark brown or dark hazel; bill and feet black.

[The Long-tailed Blue Flycatcher was seen near Entebbe and on the plains around 
Ruwenzori. It was found also in the valleys up to an elevation of $6000 \mathrm{ft}$., but was by no means a common bird.- $R . B . W$.

Cirptolopha alpina Grant. (Plate XII. fig. 3, o ; Plate XIX. fig. 12, egg.)

Cryptolopha alpina Grant, Bull. B. O. C. xvi.p. 117 (1906).

a-k. o ㅇ․ Mubuku Valley, E. Ruwenzori, 10,000-13,000 ft., 27th-31st Jan. [Nos. $1187^{*}, 1188,1190,1202,1205$. D. C. 3130,3131 * $3132,3138,3139$. R. B.H.]

l-o. o f. Mubuku Valley, 10,000-13,000 ft., 1st-20th Feb. [Nos. 159, 16. R. E. D. ; 1207. D. C.; 3171.R.B.W . ]

This species is most nearly allied to C. umbrivirens (Rüpp.) and $C$. dorcadichroa Reich. \& Neum., but has the underparts entirely brownish-buff and the middle of the abdomen whitish-buff. Iris dark brown; upper mandible brown, lower mandibic yellow; feet dark brown. Total length ca. 4.8 inches; culmen 0.5 ; wing 2.4 ; tail 2.0 ; tarsus 0.85 .

An egg of this species is of a rather pointed oval shape and slightly glossy. It is white, spotted all over with light red and lavender-grey, especially towards the larger end. It measures $\cdot 71 \times \cdot 51$ in.

[The Alpine Flycatcher was met with on Ruwenzori between altitudes of 10,000 and $14,000 \mathrm{ft}$., but was most plentiful among the tree-heaths which extend from $10,000 \mathrm{ft}$. to $12,500 \mathrm{ft}$. Its habits much resembled those of the Chiffchaff or Villow-Wren and it had a short cheerful song. A nest, found at the end of Jannary; was placed on a dry ledge of rock under a great overhanging cliff; it was domed like the nest of a Chiffchaff and composed of fine grass and moss; it contained three eggs. $-R . B . W$.

\section{CRyptolopha leta Sharpe.}

Cryptolopha leeta Sharpe, Bull. B. O. C. xiii. p. 9 (1902) [Ruwenzori]; Reich. Vü̈r. Afr. ii. p. 723 (1903); Jackison, Ibis, 1906, p. 537.

a-h. o f. Mubuku Valley, E. Ruwenzori, 6000-9000 ft., 3rd-18th Jan. [Nos. 112. R.E. D. ; 1091, 1095, 1120. D. C. ; 2084. G. L.; 3079, 3117, 3119. R. R. W. $]$

i. o. Mubuku Valley, E. Ruwenzori, $7000 \mathrm{ft}$, 23rd Feb. [No. 3175. R. B. H.]

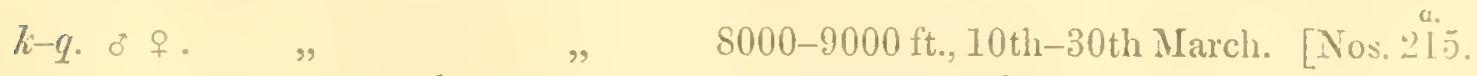

R. E. D.; 1366. D. C. ; 2261. G. L. ; 3195, 3236, 3239, 3240.R.B.W.]

r-u. o ㅇ. Butagu Valley, W. Ruwenzori, $7000 \mathrm{ft} ., 1$ st Aug. [Nos. 1766. D. U.; $3534,3.95 .35 \% 5$. R. L. II. 
Iris dark brown or dark hazel ; upper mandible brown or blackish, lower mandible brown or yellow; feet greenish-brown or greyish-green.

[This little bird was found on Ruwenzori at an altitude of between 6500 and $9000 \mathrm{ft}$., inhabiting the forest-zone and the lower parts of the bamboo. It was very plentiful in the forest and was usually to be seen in small flocks, which were busily searching for insects at the tops of the trees and moved along like a troop of Long-tailed 'Tits. It was very numerous in the Butagu Valley on the west side of Ruwenzori among the bamboo at $7500 \mathrm{ft}$.

At 10,000 ft. its place was taken by a very similar species, C. alpina, which was met with up to $14,000 \mathrm{ft} .-R . B . W$.

\section{Family H IRU Y DINID E.}

Cotile CiNcta (Bodd.).

Riparia cincta Reich. Vög. Afr. ii. p. 394 (1903).

a. 3. Mokia, S.E. Ruwenzori, 3400 ft., 12th June. [No. 1625. D. C.]

Iris dark hazel; bill and feet black.

[A few were seen on the plains near Lake Edward at the south end of Rurenzori. $-R . B . W$.

Cotile Rufigula Fischer \& Reichenow.

Riparia rufigula Reich. Vög. Afr. ii. p. 400 (1903).

a, b. of imm. Mubuku Valley, E. Ruwenzori, 8500 ft., 7th Feb. [Nos. 144, 145. R. E. D.]

Iris dark brown; bill brown; feet light brown.

These two immature birds are in fresh plumage, some of the feathers being still in moult. The upperparts are dark sooty-brown with a distinct, though slight, oily gloss; the feathers of the chin and throat have distinct dark shafts; the rest of the muderparts are sooty-brown, tinged on the breast with rufous and indistinctly margined, especially on the under tail-coverts, with pale rufous.

[A few of these Martins inhabited an open ridge in the Mubuku Valley at 8000 feet, and were seen again in a similar situation in the Luimi Valley.- R. B. W. $]$

\section{Hirundo gordoni Jardine.}

Hirundo gordoni Reich. Vïg. Afr. ii. p. 418 (1903); Sharpe, Ibis, 1907, p. 44.1. [S. Cameroon]. Hirundo neumanni Reich. t. c. p. 418 [N.W. Massailand].

a. of imm. Entebbe, $3500 \mathrm{ft}, 21 \mathrm{st}$ Nov. [No. 4. R. E. D.]

7. Imm. Mokia, S.E. Tuwenzori, $3400 \mathrm{ft}$., 6th Jan. [No. 435. R. E. D).]

lioth these birds are immature. I hare compared an adult specimen from Wadelai 
(Emin), which Dr. Reichenow considers typical II. neumanni, with the type of II. gorloni. In the former the wing measures $122 \mathrm{~mm}$; in the latter $120 \mathrm{~mm}$. The difference in size is therefore of no importance, and the colour of the under tailcoverts is not constant and cannot be relied on, the type of $I T$. gordoni having light under tail-coverts.

[Gordon's Swallow was obtained near Entebbe, and was very plentiful on the plains at the south end of Ruwenzori.-R. B. W . ]

\section{Hinuxd Emsi Reichenow.}

Hirrndo emini Reich. Vïg. Afr. ii. p. 4:20 (1903).

r. ․ 100 miles W. of Entebbe, $4000 \mathrm{ft} .$, th Dec. [No. 3036. R. B. IV.]

b. o. Mubuku Valley, E. Ruwenzori, $6000 \mathrm{ft}$, 29th Dec. [Yo. 53. R. E. D.]

c, d. +. , " , , $\quad$ 20th Jan. [Nos. 118. R. E. I).; 11 i's. D. C.]

e. ․ Mubuku Valley, E. Ruwenzori, $7000 \mathrm{ft}$. ,6th April. [No. 2279. G. L.]

Iris brown or dark brown; bill black; feet brown or dark brown.

[Emin's Swallow was not uncommon throughout the journey from Entebbe to Ruwenzori. On the mountains it was seen up to an altitude of 8500 feet. $-h . M . W$. ?

\section{Psalidoprocke albiceps Sclater.}

P'salidoprocne albiceps Reich. Vög. Afr. ii. p. 430 (1903); Jackson, Ibis, 1906, p. 532 [Toro].

a, b. o. Entebbe, $3500 \mathrm{ft}, 21 \mathrm{st}$ Nov。 [Nos. 5. R. E. D.; 1104. D. C.]

¿. . Mokia, S.E. Ruwenzori, $3400 \mathrm{ft}$., $30 \mathrm{th}$ April. [No. 1465. D. C.]

d. o. $\quad, \quad, \quad 27$ th May. [No.3420.R. R. W.]

Iris dark hazel; bill black; feet brown or dark brown.

[The White-headed Rough-winged Swallow was seen near Entebbe, and from thence throughout the journey to Ruwenzori. It was very numerous on the plains near Lake Ldwrid at the south end of Ruwenzori, and was also seen at Fort Beni on the edge of the Eturi Forest. - R. B. $W$.]

\section{PSalidoprocke Massatca Neumann.}

Psalidoprocne holomelena massaica Neum. Orn. Monatsb. xii. p. 14t (1904) [Kikuyu]; Reich. Vigg. Afr. iii. p. 829 (1905).

a-1. o \&. Mubuku Valley, L. Ruwenzori, $6000 \mathrm{ft}$. [Nos. 1093, 11ì. 113j, 1136. D.C.]

In spite of what Dr. Reichenow and Mr. Alexander have written, I consider that Prof. Neumann was fully justified in separating the present East African form from rol. IIx.-PART IY. No.5t.-March, 1910. 
1ypical $P$. holomelana from S. Africa. P. massaicr is readily distinguished by the paler and greyer colour of the under wing-coverts and axillaries, which are smoky-brown in P. holomelcenc; the latter also has the green gloss on the upperparts, especially on the crown, brighter.

[The Massai Rough-winged Swallow was numerous on Ruwenzori below the forest, and occurred up to an elevation of $8500 \mathrm{ft} .-R . B . W$.

\section{Psalidoprocne nitens (Cassin).}

Psalidoprocne nitens Reich. Vüg. Afr. ii. p. 426 (1903), iii. p. 829 (1905) ; Sharpe, Ibis, 1907, p. 4.1. [S. Cameroon].

Psalidoprocne nitens centralis Neumann, Orn. Monatsb. xï.p. 14. (1901) [Eturi].

ฉ. ․ 40 miles N.W. of Fort Beni, Semliki Valley, 3000 f., 13 th Aug. [No, 508. li. E. I).

Iris dark hazel; bill black ; feet brown.

The above specimen, which is a typical example of Prof. Neumann's $P$. n. centralis. is indistinguishable from examples from Cameroon and Gaboon. 'The British Musenm possesses a cotype of $P$. nitens from the Muni River, Gaboon (Dn Chaillu). The sooty-brown throat [cf'. Sharpe, Cat. Birds B. M. x. p. 204 (1885)] is no doubt a sign of immaturity.

[The Square-tailed Rough-winged Swallow was always to be seen in the clearings and about the native villages in the Eturi Forest. $-R . M . I V$. $]$

\section{Family PICID.E.}

1)ENDromus Caroli Malh.

Dendromus caroli Reich. Vög. Afr. ii.p. 168 (1902); Jackson, Ibis, 1906, p. 5.28 ['Toro]; Sharpe, Ibis, 1907, p. 443 [Cameroon].

a. J. Mawambi, E. Congo Forest, $3000 \mathrm{ft}, 21$ st Oct. [No. 3638. R. B. W.]

Iris dark brown; bill black; feet pale greenish-yelluw

'This West African species has been already obtained in 'Toro by Mr. Jackson's collectors, so its occurrence in the Eastern Congo Forest was to be expected.

Dendromus Taxiol aMa (Reichenow \& Neumann).

Dendromus teniolama Reich. Vüg. Afr. ii. p. 172 (1902).

Campothera hausburgi Sharpe, Bull. 13. O. C. x. p. 36 (1900) [Kenya].

Dendromus tceniolcema hausburgi Reich. t. c. p. 172.

a. [․] Mpanga Forest, Fort Portal, $5000 \mathrm{ft} ., 18 t h$ Sept. [No. 533. R. E. D.]

Iris crimson; bill dark horn; feet olive. 
Only male examples were included in the British Museum series, so this freshly moulted female is an interesting addition to the collection. It agrees with a female in Mr. Jackson's collection, but is more brightly coloured, especially on the underparts, which are strongly washed with greenish-yellow.

I) marouls nubicus (Gmel.).

Dendromus nubicus Reich. Vögr. Afr. ii. p. 178 (1902); Jackson, Ibis, 1906, p. 529 [Toro: Ankoli].

a, b. o. 80-100 miles W. of Entebbe, 3500-4100 ft., 1st \& 4th Dec. [Nos. 28. R. E. I. ; 1023. d. D. C ]

c. B. Mubuku Valley, E. Ruwenzori, $5000 \mathrm{ft.}, 23 \mathrm{rd} \mathrm{March.} \mathrm{[No.} \mathrm{2232.} \mathrm{G.} \mathrm{L.]}$

d. o. Mokia, S.L. Ruwenzori, $3100 \mathrm{ft} ., 10$ th May. [No. 1535. I). C.]

e. : . ., " , 21 st June. [No. 1658. I). C.]

I. o. Somliki Valley, $2000 \mathrm{ft}, 10$ th Oct. [No. 562. R. E. D.]

Iris dark pink, dark red, or mauve; bill black; feet olive-green or olive-brown.

[The Nubian Woodpecker was obtained near Entebbe and all around the foot of the mountains, but it was never met with at an elevation of more than $5000 \mathrm{ft}$. -li. Ii. 11.$]$

\section{Mesopicus Rutwenzori Sharpe.}

Mesepicos griseocephalus Sheliey (nec Bodd.), Ibis, 1897, p. 547 [Nyasaland] ; 1899, p. 37s

[N. of Lake Nyasa]; Neumam, J. f. O. 1900, p. 201 [Kilimanjaro]; Reich. Vüg. Afr. ii. p. 185 (1902) [part., Nyasaland].

Mesopicus ruvenzori Sharpe, Bull. B. O. C. xiii. p. 8 (1203) [Ruwenzori].

a. b. ठ․ Mubuku Valley, E. Ruwenzori, S000 ft., 21st \& 23rd Jan. [Yos. 1180. I). C. ; 2105. (I. L.]

('-e. o ㅇ. Mubuku Valley, L. Ruwenzori, $8000 \mathrm{ft}$, 2nd-8th Feb. [Nos. 1211, 1217, 1222. D. C. ]

f. $\%$. . Mubuku Valley, E. Ruwenzori, $8000 \mathrm{ft}$., 1st Mar. [Nos. 1255, 1276. D. C.] l.6. " " " "6th April. [No. 232. R. E. U.]

Iris dark brown; bill black, grey on the lower mandible; feet grey or dark grey.

'The type of Dr. Sharpe's $M$. mwen $0 r^{\circ}$ is undoubtedly quite a young bird, and is not really very closely related to $M$. spodocephalus (Bonap.), with which it has been compared. 'The adult of $M$. mumeni is closely allied to $M L$. griseocephulus (Bodd.) from S. Africa, but has a well-developed tright scarlet patch on the middle of the belly. Captain Shelley has wrongly identified birds from Nyasaland with the latter form, which, as a rule, has no trace of a scarlet patch on the middle of the belly, though a male specimen from Drakensburg ( $F . A$. Butler) and a female specimen 
from Zululand (Gorlge) show traces of a dull crimson patch. The range of $M$. ruwen$z 0 r^{\circ}$, as at present known, extends from Ruwenzori to Kilimanjaro, Tanganyika, and Cryasaland.

['The Ruwenzori Woodpecker was obtained only at altitudes of from 6000 to $10,000 \mathrm{ft}$., and was most plentiful in the forest-zone from 6500 to $5000 \mathrm{ft}$. It was nowhere numerous. $-R . B . W$.

Mesoricus peocepiratus (Swainson).

Mesopicus procephalus Grant, Ibis, 1902, p. 425; Jackson, Ibis, 1902, p. 641 [Enteblbe].

a. o* 60 miles W. of Entebbe, $3500 \mathrm{ft} ., 29 t \mathrm{th}$ Nov. [No. 1018. D. C.]

b. o. Mubuku Valley, E. Ruwenzori, $5000 \mathrm{ft}$, 14th March. [No. 1436. D. C.]

$c-g$. of ㅇ. Mokia, S.E. Ruwenzori, $3400 \mathrm{ft}$. , 5th-24th May. [Nos. 1508, 1508, $1545,1617,1619$. D. C.]

Iris dark brown or reddish-brown; bill black, whitish on the lower mandible; fect dark grey.

The relations of this species have already been fully discussed in my paper quoted above.

['The Goertan Woodpecker was observed near Entebbe and throughout the acaciacountry at the south end of Ruwenzori, as well as in the Semliki Valley. It was found on the lower slopes of Ruwenzori up to about $5000 \mathrm{ft}$., but above that its place was taken by 1 . ruwenzori Sharpe.-R. B.W.]

\section{Mesopicus ellioti (Cassin).}

Mesopicos ellioti Hargitt, Cat. Birds B. M. xviii. p. 374 (1890) [type described]; Reich. Vüg. Afr. ii. p. 185 (1902); Sharpe, Ibis, 1907, p. 413 [Cameroon].

1. 3. Mpanga Forest, Fort Portal, $5000 \mathrm{ft} ., 19$ th Sept. [No. 541. R. E. D.]

Iris crimson; bill slate-colour; feet olive-green.

'This specimen agrees in every detail with the type-specimen, which is also a male and was procured at the Muni River, Gaboon. The occurrence of this species in the Mpanga Forest, though not unexpected, is of great interest.

[A few examples of Elliot's Woodpecker were seen in the Mpanga Forest about 30 miles east of Ruwenzori, but the species was never met with on that range. $-R . B . W^{r}$.]

\section{Desmiopicus zanzibari Malh.}

Dendropicos hartlaubi Malh.; Reich. Vög. Afr. ii. p. 193 (190:2).

Dendropicus zanzibari Grant, Ibis, 1905, p. 211 [S. Uganda].

a. ㅇ․ Entebbe, $3500 \mathrm{ft} ., 21 \mathrm{st}$ Nov. [No. 1003. I). C.]

Iris dark red; bill black; feet dark olive-green. 
There can be no doubt that Hargitt was perfectly right in referring Dendropicus hartlaubi Malh. to the synonymy of Picus cardinalis Ginel. $=(P$. guineensis Scop.). Professor Neumann has attempted to clear up this difficult little group of Woodpeckers ( $f f . J . f$. O. 1900, pp. 206-207); but he seems only to have added to the confusion already existing by introducing two new names, neither of which can stand.

DENDROPICUS LAFressay Malh.

Dendropicos lafresnayei Reich. V̈̈g. $\Lambda$ fr. ii. p. 195 (1902).

Dendropicus lafiesnayi Grant, Ibis, 1905, p. 211 [S. Uganda]; 1908, p. 309 [Lake Kivu].

$a-c . \delta^{*}$. Mubuku Valley, E. Ruwenzori, $6000 \mathrm{ft}, 17$ th-22nd Jan. [Nos. 2092, 2096, 2107. G. L.]

a.e. ơ. Mubuku Valley, E. Ruwenzori, $5000 \mathrm{ft.}, 14$ th \& 23rd March. [Nos. 1347. I). C. ; 3251.R. B.W.]

f, g. o q. Mokia, S.E. Ruwenzori, 3400 ft., 18th \& 20th May. [Nos. 1536. I). C.; 23T4. G. L.]

h. ㅇ. Mokia, S.E. Ruwenzori, $3400 \mathrm{ft.}, 23 \mathrm{rd}$ June. [No. 1669. D. C.]

i. ‥ Lower Semliki Valley, $2000 \mathrm{ft}$, 10th Oct. [No. 3624. R. B.W.]

Iris dark crimson; bill grey or dark horn-colour; feet olive-green.

[Lafresnay's Woodpecker was found on Ruwenzori up to $7000 \mathrm{ft}$., following up the valleys from the plains. It was not uncommon in the acacia-country along the foot of the mountains at the south end and in the Upper Semliki Valley.- R. B. W . ]

1)exdropicus Pecilol æurs Reichenow.

Dendropicos precilalemus Reich. Vüg. Afr. ii.p. 196 (1902).

Dendropicus pocilolamus Jackson, Ibis, 1906, p. 529 ['T'oro].

Dendropicus nendensis Neumann, Orn. Monatsb. ix. p. 184 (1901).

a. o. 60 miles W. of Eitebbe, $3500 \mathrm{ft}, 29$ th Nov. [No. 1019. I). C.]

b. q. 100 miles W. of Entebbe, 4100 ft., 4th Dec. [No. 1034. I). C.]

$c$, $l$. $q$ et $\delta \mathrm{imm}$. Mubuku Valley, E. Ruwenzori, $5000 \mathrm{ft}, 14$ th March. [Nos. 3217, 3218. R. B. W.]

e. ․ Mubuku Valley, E. Ruwenzori, $5000 \mathrm{ft}$, 5th April. [No. 229. R. E. U.]

Iris dark red; bill bluish-black; legs grey, bluish, or olive-brown.

The immature male (No. 3218) has the general colour of the back greyish-brown tinged with olive, instead of golden-olive, and lacks the yellowish wash on the under parts, which are whitish-grey. 'The first primary-quill measures about 1.1 inch, and is much longer than in any of the adult birds. 'This specimen agrees exactly with the bird described as $D$. nandensis by Prof. Neumann. It was procured along with a typical female of $D$. pæcilolcemus (No.3217), which was marked "breeding" and was probably the parent bird. 
[Reichenow's Spotted Woodpecker was obtained near Entebbe and all around the foot of the mountains. It also occurs in the valleys up to an altitude of about $5000 \mathrm{ft}$. $-R . B . W$.

\section{Family I I D I CA T OR I D E.}

IXDICATOR VARIFGATUS Less.

Indicator variegatus Reich. Vög. Afr. ii. p. 108 (1902); Grant, Ibis, 1908, p. 309 [S.IF. Uganda].

a-c. of et i imm. 110-130 miles W. of Entebbe, $4000 \mathrm{ft}$, 5th-10th Dec. [Xos. 29, 42. R. E. D. ; 2029.G.I.]

Iris olive-brown; bill dark horn-colour; feet dark olive.

I have already drawn attention to the differences in plumage between the adult and young of this species in my paper on Mr. Douglas Carruthers' collection quoted above.

['The Variegated Honey-Guide was seen only during the journey from Entebbe to liuwenzori. The note is a curious long-drawn trill.- R. B. H'.]

INDicator Minor Steph.

Indicator minor lieich. Vüg. Afr. ii. p. 110 (1902).

Indicator pygmaus lieich. t. c. p, 11:.

indicator minor teitensis Neumann, J. f. O. 1900, p. 195.

". o. Mubuku Valley, li. Ruwenzori, $5500 \mathrm{ft}, 22 \mathrm{nd}$ Feb. [No, 1262, D. C.]

lris dark hazel; bill black; feet olive-grey.

I very much doubt if $I$. pygmerus Reichenow ( $=I$. minor teitensis Neumann) can be distinguished from $I$. minor, except perhaps by the most trifting difference in the size of the bill and wing. 'The supposed difference in the measurements given by Dr. Reichenow (Vög. Afr. ii. p. 104) is due to sex and is of no specific value, the trpe specimen of his $I$. pygmans being a female with a wing measuring about $80 \mathrm{~mm}$.

The following measurements clearly illustrate the above remarlis:-

Measurements of wing.

Nale. Female.

Waliko, Abyssicia . . . . Ss

Wagga Mts., N. Somaliland . . . 8\%

-

, $\quad$ ". . 87

Athi liver, B.E. Atrica . . . . 90

Mubuku Valley, E. Ruwenzori . . 89

Swaziland, So Alrica. . . . . 89

Fland's l'ost, , . . . . 9: 
[A few of these Honey-Guides were seen in the lower wooded valleys in the central part of the range, but they were never seen above an altitude of $5500 \mathrm{ft}$. $-R . B . W$.]

Ixdicator Exilis (Cassin).

Indicutor exilis Reich. Vög. Afr. ii.p. 113 (1902); Sharpe, Ibis, 1907, p. 440 [Cameroon].

a. +. Irumu, Eturi Forest, 3000 ft., 16th Oct. [No. 569. R. E. D.]

Iris brown; bill and feet slate-colour.

The wing measures $2 \cdot 7$ inches (=69 mm.).

['The above-mentioned specimen of this small Honey-Guide (a female) was evidentiy breeding. The few observed were only seen in the Eturi Forest. $-R . B . W$.

\section{Family CAPITONID E.}

LiBirs equatorialis (Shelley).

Lybins requatorialis Reich. Vög. Afr. ii. p. 119 (1902); Jackson, Ibis, 1906, p. ऽ30 [Toro].

a, b. o ․ Mubuku Valley, E. Ruwenzori, $5000 \mathrm{ft} ., 22 \mathrm{nd} \& 23 \mathrm{rd} \mathrm{March.} \mathrm{[Nos.} 220$. R. E. D.;2228. G. L.]

c, d. of o . Mokia, S.E. Ruwenzori, 3400 ft., 10th \& 30 th May. [Nos. 3y4. R. E. D. ; 1533. D. C.]

e. ‥ Mokia, S.E. Ruwenzori, $3400 \mathrm{ft}, 13$ th June. [No. 451. R. E. D.]

Iris dark brown; bare skin round the eje pale yellow; bill whitish; feet blackish, dark brown, or grey.

[A few examples of the Equatorial Barbet were seen in the wooded valleys of Ruwenzori all along the range. The species was by no means common and was never observed above an altitude of $5000 \mathrm{ft}$. It was also seen in the Semliki Valley, near Lake Albert.-R.B.W.]

'Tricholdira ansorger Shelley.

Trichohema ansorgii Shelley, Bull. B. O. C. v. p. 3 (1895) [Uganda]; Rcich. Vör. Afr. ii. p. 131 (1902).

a. o. Muanga Forest, Fort Portal, $5000 \mathrm{ft} ., 17$ th Sept. $\quad[$ No. 522, R. E. D.]

Iris crimson; bill and feet black.

The type of this species, which was procured by Dr. WV. J. Ansorge at Port Alice, Lake Victoria, is quite a young birl. Adult specimens have now been sent home from Entebbe (Jackson Collection) and the Mpanga Forest, and show that T. ansoryci is really quite distinct from the allied 'T. hirsutum (Swains.) from the Gold Coast. 'Ihis fact was not very self-evident when only the type-specimen was available for comparison. 
more especially as the feathers are wanting on the sides of the face, and in that condition it is scarcely possible to distinguish it from immature examples of $T$. hirsutum. It must be further noted that younger birds of this group have the spots on the head and back, as well as the margins of the wing-feathers, bright golden; whereas in the adult these markings are pale lemon-yellow and the crown is uniform black.

[The single specimen of Ansorge's Barbet obtained in the Mpanga Forest was the only one seen. $-R, B . H$. $]$

\section{'Trichol ena RADCLIFFei Grant.}

Tricholema radcliffei Grant, Bull. B. O.C. xv. p. 29 (1904).

Tricholcema lacrymosum Reich. (nec Cab.) Vög. Afr. iii.p. 824 (1905).

a-y. o o et o o imm. Mokia, S.E. Ruwenzori, $3400 \mathrm{ft}$., 2nd-22nd May. [Nos. 269, 270, 316. R. E. D.; 1554, 1555. D.C.; 3398, 3399. R.B.IV.]

h. $\delta$ imm. Mokia, $3400 \mathrm{ft.}, 24$ th June. [No. 1678. D. C.]

$i, l$. $q$ et $\delta$ imm. Mokia, $3400 \mathrm{ft} ., 6$ th July. [Nos. 1718, 1719. D. C.]

Iris dark brown or yellow; bill and feet black.

'Though some doubt has been cast on the validity of this species by Dr. Reichenow and others, it appears to be well characterised and perfectly distinct from the allied $T$. lacrymosum Cab. 'The adults of the present series all agree with the type-specimens from Mulema (Doggett). Younger birds differ from the adults in having the black spots on the sides of the underparts smaller and more oval in shape. No. 3399, a female procured by Mr. Woosnam, is of special interest as illustrating the change of plumage from the immature to the adult. When I compared $T$. ralcliffei with $T$. lacrymosum I stated that the latter differed in having the underparts washed with buff instead of yellow. 'This, however, is not a reliable character, for specimens from Mlt. Kenya (Delamere), which have since been added to the collection, show that in freshly-killed examples of both species the underparts are washed with yellow.

[Quite a number of Delmé Radcliffe's Barbet inhabited the acacia-forest around the south end of Ruwenzori and the upper part of the Semliki Valley, but they were never seen on the mountains. $--R . B . W$.

Grimobecco stabesi Grant.

Gymnobucco sladeni Grant, Bull. B. O.C. xix. p. $42(190 \%)$.

a. ․ Mawambi, E. Congo Forest, $2500 \mathrm{ft} ., 31 \mathrm{st}$ Oct. [No. 3651.R. B. II. Type of the species.]

This species is most nearly allied to G. peli Hartl., but is distinguished by having the bill black. It approaches G. cinereiceps Sharpe in the colour of the bill and in having the feathers of the throat, as well as the basal part of the feathers of the chest, grey. It may be at once distinguished from that species by having the head covered 
with feathers. Iris crimson; bare skin on head black; feet black. Total length ca. 6.2 inches; culmen 0.78 ; wing 3.5 ; tail 1.9 ; tarsus 0.78 .

[A single specimen of Sladen's Barbet was shot in the Congo Forest, where they are probably not uncommon. In the Mpanga Forest its place appears to be taken by the closely-allied $G$. cinerciceps Sharpe, of which two specimens were procured.-.. i. Ji. II.

\section{Grunobucco cinereiceps Sharpe.}

Gymnobucco cinereiceps Sharpe, Ibis, 1891, p. 122 [MIt. Elgon] ; Reich. Vög. Afr. i.p. 139 (1902); Jackson, Ibis, 1906, p. 531 [Toro].

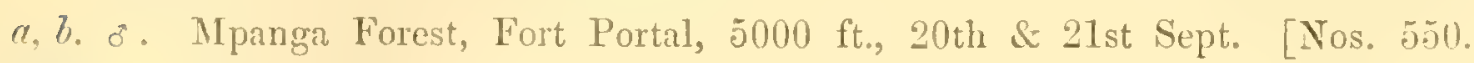
R. E. D.; 3590.R.B. Wr.]

'The colour of the brush-like tufts behind the nasal openings varies considerably in different individuals. In the type-specimen and other examples collected at Mt. Elgon in February the tufts are light ochre-brown. In two examples killed at Nandi in May the tufts are of much the same colour, while in birds from the Mpanga Forest killed in September and in several from the Kibera Forest, Toro, procured in January, February, and September, they are deep chestnut-brown. One example, however, from Toro, killed in October, resembles the type from Elgon, the difference in colour being no doubt due to wear. Freshly-moulted and worn birds look so different that it seems desirable to draw attention to the cause.

[Shape's Grey-headed Barbet was plentiful in the Mpanga Forest. It was always observed high up in the largest trees. $-R . L . W$.

\section{Barbatula mavidiri Grant.}

Barbatula mfumbiri Grant, Bull. B. O. C. xix. p. 10\% (1907); id. Ibis, 1908, p. 311 [Nufunbiro Vulcanoes].

Barbatula leucolaima nyanse Neumann, J. f. O. 1907, p. 317.

The adult male is most nearly allied to B. leucolame (Verr.), but is larger ; the back black, glossed with dark bottle-green, the chest greyish-white, and the rest of the underparts duller and of a more greenish-yellow colour. In the coloration of the underparts it closely resembles $B$. jacksoni Sharpe, but the rump is pale sulphur-yellow as in li. Teucolema atud not bright chrome-yellow. Iris dark brown or dark hazel; bill and feet black. 'Total length ca. 4.0 inches; culmen $0.5-0.55$; wing 2.3 ; tail 1.15 ; tarsus $0 \cdot 6-0 \cdot 65$.

'The arlult female is similar to the male. 'Total length ca. 4.0 inches; culmen 0.55 ; wing $2 \cdot 2$; tail $1 \cdot 1$; tarsus $0 \cdot 62$.

a-c. of. Mubulin Valley, E. Ruwenzori, 6000-7000 ft., 16th-22nd Jan. [Nos. 115. I. E. L.; 3097, 3104.R. R. W.]

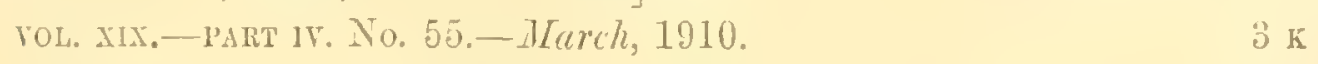


d-k. o . . Mubuku Valley, E. Ruwenzori, 5500-7000 ft., 22nd-25̆th Feb. [Nos.

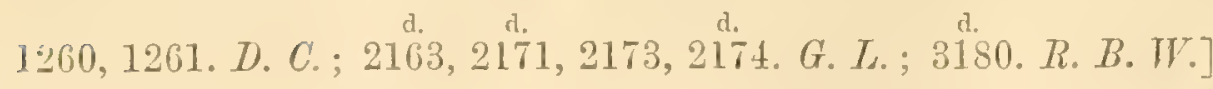

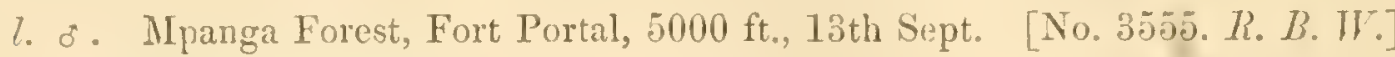

The type-specimen of this species was procured by Mr. Douglas Carruthers on the Mufumbiro Volcanoes at an altitude of $6000 \mathrm{ft}$. It is precisely the same as the birds procured by the Expedition on Eastern Ruwenzori at a similar altitude. 'The male from the Mpanga Forest shot in September has the chest pale whitish-grey, paler than in the birds from East Ruwenzori, but in the green gloss of the upperparts and in other respects it agrees with the present species.

I am unable to distinguish typical examples of $B$. lencolama from $B$. l. togoensis Neumann (cf. J.f. O. 1907, p. 347).

[The Congo Forest teems with small Barbets, and one soon becomes so used to their persistent piping that one ceases to notice the sound. But although they exist in such numbers it is only on rare occasions that they are shot or even seen, for they have a habit of remaining motionless for long periods, perched high up in a tree, all the while emitting a succession of piping notes at regular intervals. It is most difficult to tell where the sound is coming from; and when disturbed the bixd darts off anong the thick foliage and is lost until it once more commences piping. This species was also plentiful in the 11 panga Forest and occurred on Ruwenzori up to $\$ 500 \mathrm{ft}$., but was by no means numerous. $-R . B .[V$.

\section{Batrbatula centralis Reichenow.}

Barbatula centralis Reich. Vög. Afr. ii. p. 150 (1902).

$a-e . \delta^{*}$ ㅇ. Molia, S.E. Ruwenzori, $3400 \mathrm{ft}, 4$ th-21st May. [Nos. 217. R. E. D. ; 1596. D. C.; 3316, 3357, 3365. R. B.W.

f. ‥ Mokia, S.E. Ruwenzori, $3400 \mathrm{ft}$, 1st June. [No. 3436.R. R. W.]

g. ․ $\quad, \quad, \quad$, 2nd July. [No. 4.74.R. E. D.]

Iris dark brown; bill and feet black.

These small Barbets require careful revision. At the present time I am sure far too many species are recognised. Prof. Neumam has recently separated a bird from the Lower Blue Nile under the name of $B$. chrysocoma zealitzi. It differs from B. chrysocoma in having the pale portions of the feathers of the back deep golden-yellow. 'This character may be a good one, but among the females of $B$. centralis from Mokia, S.E. Ruwenzori, No. 3316 has the light portions of the feathers of the back pure white, while Nos. 1596 and 3357 , also females procured at the same time and place, have these parts pale lemon-yellow, although all are undoubtedly of the same species.

In one male the wing measures $2 . t$ inches; in six females it varies from 2.3 to $2 \cdot 1$ inches $(=58-61 \mathrm{~mm}$.). 
In B. chrysocoma [=B. c. guineensis Reichenow, Vög. Afr. ii. p. 149 (1902)] the wing measures $2 \cdot 2$ inches ( $=56 \mathrm{~mm}$.).

['This small Barbet was found only at the south end of Ruwenzori among the rather dry acacia-forest on the plains, and in the wooded valleys of the lower part of the range. It was not very plentiful.-- R. B. II.]

Tracimpironus elgonersis Sharpe.

Trachyphonus elgonensis Sharpe, Ibis, 1891, p. 122 [MIt. Elgon].

Trachylemus purpuratus elgonensis lieich. Vög. Afr. ii. p. 160 (1902).

a. ․ Mpanga Forest, Fort Portal, 5000 ft., 22nd Sept. [No.3607. R. B. W.]

Iris crimson; bill yellow; feet greenish-grey.

The most important character by which this form may be separated from examples of typical T. purpuratus Verr. has been omitted in the original description, the light streaks on the fore-neck and upper chest being much less numerous and not nearly so pale in T'elgonensis. This character is very marked when series of the two forms are compared. The bill is certainly somewhat smaller; but the size, the crimson wash on the forehead (though a little brighter in the type-specimens), and the crimson border to the black of the thrnat are the same in both species.

[A single specimen of the Elgon Barbet was shot out of a small flock of six or seven birds in the Mpanga Forest, but that was the only occasion on which the species was seen. $-R . B . H$.

\section{Family MUSOPHAGID E.}

CORITh EOLA CRistata (Vieill.).

Corythceola cristata Reich. Vög. Afr. ii. p. 26 (1902).

a, b. o. Mpanga Forest, Fort Portal, 5000 ft., 17th Sept. [Nos. 512, 513. li. E. I.]

c. o. 50 miles N.W. of Fort Beni, 3000 ft., 15th August. [No. 2451. G. L.]

Iris crimson or dark red; bill yellow, red at the tip; feet black.

[The Great Crested 'Touraco was common in the Congo Forest and also in the Mpanga Forest, but it was not seen on the mountains.

The beantiful deep sonorous "curn curu curn" of this bird resounding through the silent depths of the woods is one of the most impressive and characteristic sounds of the great Congo Forest.

'The native (Swaheli) name for several species of 'Touracos is "curu curu." - R. $B . I F$.]

Mropophaga ross.m Gould.

Musophaga rosse Reich. Vög. Afr. ii. p. 29 (1902); Jaclison, Ibis, 1906, p. 5.24 [Aulsoli]; Grant, Ibis, 1908, p. 312 [Lake Kivu].

a. ন. Lutebbe, $3500 \mathrm{ft} ., 21 \mathrm{st}$ Nov. [No. 7. R. E. D.] 
Iris dark brown; bill yellow, upper mandible orange at the base ; feet black.

Lady Ross's 'Touraco was plentiful at Entebbe, but was not seen either in the 'Toro district or on Ruwenzori.- $R . B . W$.

GyMioschizoriIs LeOPOLDI (Shelley).

Gymnoschizorhis leopoldi Reich. Vög. Afr. ii. p. 37 (1902); Jackson, Ibis, 1906, 1). 525 [Ankoli] ; Grant, Ibis, 1903, p. 311 [S.W. Uganda].

a, b. o f. Mokia, S.L. Ruwenzori, $3400 \mathrm{ft}$, 15th \& 1Sth May. [Nos. 1550. D. C. ; 3374.R. B. W.]

Iris dark brown; bare slin on the sides of the face and throat black; bill and feet black.

[A few examples of Iring Leopold's Touraco were seen in the acacia-trees around the south end of Ruwenzori; it was evidently a rare bird. $-R . B . W$.]

\section{Gallirex Johnstorl Sharpe.}

Gallirex johnstoni Sharpe, Bull. B. O.C. xi.p. 57 (1901) [Ruwenzori]; id. Ibis, 1902, p. 112, pl. v.; Reich. Vög. Afr. ii.p. 41 (1902).

Ruwenzoromis johnstoni Jackson, Ibis, 1906, p. 523 [Ruwenzori].

a. ơ. Mubuku Valle5, E. Ruwenzori, $9000 \mathrm{ft} ., 26 \mathrm{th}$ Jan. [No. 3217. R. R. W.]

b-h. 우. " ",$\quad$ 2nd-1Sth Feb. [Nos. 1209, 1210, d. d.

1233, 123i, 1238, 1239. D.C. ; 3163.R. IB.W.]

i-l. o o. Mubuku Valley, E. Ruwenzori, 9000 ft., 10 th March. [Nos. 1312, 1313, 1314. D.C.]

Iris dark hazel or chocolate; eyelid scarlet; bare skin in front of the eye yellow, that below and behind the eye scarlet; bill light green, black at the tip and pink at the base; feet black.

A closely allied form of this splendid Touraco has been recently discorered by Ilerr R. Graner on the IIufumbiro Volcanoes*, and has been described by Prof. Neumamn as Ruwenzorornis johnstoni Fivnenses [cf. Bull. B. O. C. xxi. p. 51 (190S)]. 'The fact that that species has the area round the eye feathered as in Gallirex proves that the genus Ruwenzorcmis, proposed by Prof. Neumann, is superfluous.

[Johmston's 'Touraco inhabits the upper part of the forest-zone. It is most plentifiu] at an altitude of about $9000 \mathrm{ft}$, among the bamboo and Podocarpus trees, and feeds largely on the berries of the latter. It was occasionally to be found as low down as $\$ 500 \mathrm{ft}$., but never lower, and was sometimes seen as high as $11,000 \mathrm{ft}$.

* Professor Neumann gires the locality " Western Kivu Volcanoes"; but there has eridently becn some confusion about the locality, for Mount Sabjingo (or, as it is more correctly $\pi$ ritten, Sabyino) forms part of the II fumbiro Mountains and lies to the north-cast of Lake Kiru. 
The note is loud and shrill, totally unlike that of Turacus emini, which has a lowtoned musical "curung curung " repeated over and over again.

Although chiefly to be met with in the Podocarpus trees, birds might now and then be seen perched on the end of a long bamboo. Like its ally, T. emini, it was far more often heard than seen, and it was some weeks before we identified the shrill laugh so often heard among the bamboos as the voice of Johnston's 'Touraco. $-R . B . W$.

Turacus EMrni Reichenow.

Turacus cmini Reich. Vög. Afr. ii. p. 50, pl. iv. figr. 2 (1902); Dubois, Aun. Mius. Congo, Zool. (4) i. fasc. i. p. 4, pl. iii. fig. 1 (1905); Jackson, Ibis, 1906, p. 523 [Rumenzori].

Turacus schütti errini Neumann, Nov. Zool. xv. p. 375 (1908).

n. +. Mpanga Forest, Fort Portal, $5000 \mathrm{ft}, 21 \mathrm{st}$ Sept. [No. 3593. R. B. W.]

b. o. Mubuku Valley, E. Ruwenzori, $9000 \mathrm{ft} .9$ th Jan. [No. 1126. D. C. $]$ d.

r-l. of ㅇ. " $, \quad, \quad 8000 \mathrm{ft}, 2$ 2nd-25th Feb. [Nos. 1228, 1229,

1230, 1231. D. C.; 2139, $2158,2159,2165,2175$. G. L. $]$

m. o imm. Mubuku Valley, E. Ruwenzori, 9000 ft., 1st March. [No. 1280. D. C.]

n. o. Fort leni, Semliki Valley, 3000 ft., 22nd July. [No. 173S. D. C]

Iris dark brown; eyclid vermilion; bill black, base of the lower mandible dark red ; feet black.

['The forest in the central part of the Semliki Valley on the west of Ruwenzori is undoubtedly the headquarters of Emin's 'Iouraco, and there it was extremely numerous. It was seen throughout the eastern parts of the forest, and westwards as far as Basoko, and was not uncommon in the Mpanga Forest.

On Ruwenzori it was fairly common throughout the forest-zone, and was seen up to an altitude of about $9000 \mathrm{ft}$, , but above this its place was taken by Gaflirex johnstoni. The Touracos run so fast and so nimbly along the boughs of the trees that they appear more like squirrels than birds. They were always difficult birds to procure, and were far more often heard than scen, $-R . B . I V$.

\section{Family CUCUIA I}

Centropus occidentalis Neumann.

Centropus monachus Jackson, Ibis, 1906, p. 528 [Toro]; Sharpe, Ibis, 1907, p. 439 [Cameroon].

Centropus monaclius occidentalis Ncumann, Bull. B. O.C. xxi. 1. 87 (1908) [Ogowe R.].

๙. o. Mubuku Valley, E. Ruwenzori, $5000 \mathrm{ft}$., 4th April. [No. 2271. G. L.]

b. ㅇ. Fort Beni, Semliki Valley, 3000 ft., 20th July. [No. 2416. G. L.]

Both these examples belong to the darker-backed southern form with brown imner secondaries, which has very properly been separated by Prof. Neumann fiom C. monachus Rüpp., from Abyssinia. 
The adult female $(\zeta)$ is in moult, and the partially grown upper tail-coverts resemble the older feathers, being black glossed with green and barred with buft. In the most adnlt female specimens the upper tail-coverts are uniform black glossed with green and devoid of buff bars. The uniform upper tail-coverts are apparently assumed at an earlier age by the male than by the female.

Centropus superchloses Hempr. \& Ehr.

Centropus superciliosus Reich. Vög. Afr. ii.p. 65 (1902).

a. ․ 80 miles W. of Entebbe, $3700 \mathrm{ft}$, 2nd Dec. [No. 20. R. L. D.]

b. 万. Mokia, S.E. Ruwenzori, $3400 \mathrm{ft}, 26 \mathrm{th}$ April. [No. 239. R. E. D.]

c-h. o o f et os $9 \mathrm{imm}$. Mokia, S.E. Ruwenzori, $3400 \mathrm{ft}$, 12th-31st May. [Nos. 282, 330, 375. R. E. D.; 1551. D. C.; 2287. G. L. ; 3433. R. B. W.]

$i-$.. $\delta$ o et $q \mathrm{imm}$. Mokia, S.E. Ruwenzori, $3400 \mathrm{ft}$., 1st-12th June. [Nos. 416, 449. R. E. D.; 3439.R.B.W.]

Adult. Iris crimson or red (in No. 3439 dark brown); bill black; feet blue or bluish-grey.

Immature. Iris grey or stone-colour; bill black; feet slate-colour.

The colour of the underparts varies considerably in adult examples of this species; in some the ground-colour is strongly washed with buff, in others it is nearly white (as is the case in all adult birds from Solsotra). 'This difference in tint, however, is due neither to locality nor season, for two adult males (Nos. 239 and 330 ) from Mokia, killed respectively in April and May, represent both types of coloration.

[A few examples of the White-eyebrowed Lark-heel Cuckoo were seen near Enteblie: they were very plentiful among the acacia-trees at the south end of Ruwenzori. The flight of this bird is remarkably weak and laboured, and during windy or rainy weather it appears quite helpless and almost unable to fly. Unless hustled, it usually works its way to the top of a thom-bush as a point of vantage, from which it makes a blundering dive into the bottom of the next bush.

In the early morning its call might be heard in every direction, and Mr. F. J. Jackson has aptly compared it with the sound of water beirg poured quickly from a large bottle.-R. B. W.]

Full details of the habits and call of this Cuckoo will also be found in my paper on the Birds of Sokotra [ $f$. Nat. Hist. Sokotra and Abd-el-Kuri, Birds, p. 43 (1903)].

\section{Coccystes CAFER (Lichtenstcin).}

Coccystes cafer Reich. Vög. Afr. ii. p. 76 (1902).

a, b. o . Mokia, S.E. Ruwenzori, $3400 \mathrm{ft}, 27$ th \& 30 th April. [Nos. 240. R. E. D.; 1462. D. C.] 
c-f. of ot ot juv. Mokia, S.E. Ruwenzori, $3400 \mathrm{ft}$, 1st-25th May. [Nos. 352. R. E. D.; 1470, 1612. D.C.; 3417.R. B. IV.]

g. ㅇ. Mokia, S.E. Ruwenzori, $3400 \mathrm{ft}, 16 \mathrm{th}$ June. [No. 3494. R. B.W.]

Iris dark brown.

The width of the black stripes on the throat and chest appears to be a matter of age; they are much narrower in the birds of the year (such as Nos. 1470,3417), and very much wider in the adult males (Nos. 246, 1462, 1612) [cf. remarks by Capt. Shelley, Cat. Birds B. M. xix. p. 222 (1891)].

Coccrstes jacobinus (Bodd.).

Coccystes jacobinus Reich. Vör. Afr. ii. p. 78 (1902); Jackson, Ibis, 1906, p. 526 [Toro].

a,b. $\delta^{\circ}$. Mokia, S.E. Ruwenzori, 3400 ft., Ist-3rd May. [Nos. 1489. D. C.; 2309. G. L.].

Iris dark hazel; bill black; feet very dark grey.

\section{Ceutmimochares aËreus Vieill.}

Ceuthmochares aereus Reich. Vüg. Afr. ii. p. 73 (1902); Sharpe, Ibis, 1907, p. 440 [Cameroon]; Grant, Ibis, 1908, p. 312 [Ponthierville, Upper Congo].

Centhmochares acrens intermedius Sharpe; Reich. t. c. p. 74.

Ceuthrochares intermedius Jackson, Ibis, 1906, p. 522 [Toro].

a. ․ 10 miles N.W. of Fort Beni, 3000 ft., 10th Aug. [No.502. R. E. D.]

b,c. o. Mpanga Forest, Fort Portal, $5000 \mathrm{ft.}$, 17th \& 21st Sept. [Nos. 530. R. E. U.; 3594.R. H. W.]

Iris dark red, chestnut, or crimson; bill yellow; feet black.

\section{Cercococcyx Mechowi Cabanis.}

Cercococcyx mechowi Reich. J. f. O. 1897, p. 1\%, pl. i. (Centrococcy.e mechowi) [Togo]; id. Vüg. Afr. ii. p. 84 (1902); Jackson, Ibis, 1906, p. 526 [Toro]; Sharpe, Ibis, 1907, p. 436 [Cameroon].

a. ․ Mpanga Forest, Fort Portal, 5000 ft., 20th Sept. [No. 3589. R. B. H.]

๖. o imm. Nubuku Valley, E. Ruwenzori, $7000 \mathrm{ft}, 11$ th Jan. [No. 3098. R. B. W.

Iris dark brown; bill horn-colour (adult) or dark brown with the lower mandible greenish (immature); feet yellow.

Captain Shelley [cf. Cat. Birds B. M. xix. p. 265 (1891)] gives a description of this species, but states that it was only known to him at that date from the description. As a matter of fact, the British Iluseum contained at least two examples, but these were wrongly referred to Cuculus solitarius Steph., and will be found in the list of 
specimens of that species catalogued as follows:- " $d^{\prime}, e^{\prime}$. Imm. sk. Gold Coast (Aubinn). Shelley Coll."

C. mechowi is easily recognised by its much longer tail, which in the present examples measures $7 \cdot 6$ inches, $0^{*} \mathrm{imm}$. $7 \cdot 4$, as compared with about 6 inches in C. solitarius.

\section{Cuculus solitarius Stephen.}

Cuculus solitarius Rcich. Vög. Afr. ii. p. 87 (1902); Jackson, Ibis, 1906, p. 527 [Ruwenzori; Toro]; Sharpe, Ibis, 190\%, p. 435 [Cameroon]; Grant, 1bis, 1908, p. 312 [N.W. of Lake Tanganyika].

$a-f$. o o et i imm. Mubuku Valley, E. Ruwenzori, 7000-\$000 ft., 7th-23rd Jan. [Nos. 2078, 2091, 2109. G.L.; 3083, 3099, 3100. R. B. W. ]

\%. ․ Mokia, S.E. Ruwenzori, 3400 ft., 29th April. [No. 254. R. E. D.]

$h, i .0$. " $\quad$ " $\quad$ 9th \& I th Mny. [Nos. 1532, 1558. D.C.]

Iris dark brown; bill black, base of the lower mandible yellow ; feet yellow.

An apparently adult male (No. 1558), killed on the 14th of May, is in curious plumage. The throat is entirely grey, while the bright chestnut band which usually occupies the fore-neck and chest is merely indicated by a few rufous and buff feathers. A second adult male (No. 1532), killed at the same place on the 9th of May, is in perfectly normal plumage.

The female usually has the band across the fore-neck much paler chestnut and heavily barred with black; but in one female ( $\mathrm{No} .3083$ ) the chestnut is quite as bright as in the male, and the black bars are less conspicuous.

Younger birds have the basal part of the onter web of the primaries barred with buff, and the innermost secondaries and greater wing-coverts narrowly margined at the tip with white.

[During January and February the forest-zone on Ruwenzori resounded with the rotes of the Solitary Cuckoo; but in March and April the birds had either nearly all grone or had become silent. The call is made up of thrce notes, which, according to Mr. Bates, have been variously expressed "Piet-mijn-vrow" or "Zil-so-foé," meaning "Who brings the news?" It was also heard in the Congo Forest and at the south end of Ruwenzori, as well as in the Mpanga Forest. On the mountains this species never ascended abore an altitude of $8500 \mathrm{ft} .-R . B . H$.

Cimisococcra ctrelus (Budd.).

Chrysococcyx cuprens Rcich. Vög. Afr. ii. p. 94 (1902); Stark \& Sclatcr, B. S. Afr. iii. p. 189 (1903); Sharpe, Ibis, 190\%, p. 438 [Cameroon].

a. ?. Mokia, S.E. Ruwenzori, $3400 \mathrm{ft} ., 28 \mathrm{sth}$ Apri]. [No. 1452. D. C.] 
b-d. o o imm. Mokia, S.E. Ruwenzori, $3400 \mathrm{ft.}$, 4th-26th May. [Nos. 379. R. E. D.; 3322, 3359. R. B.W.]

$e-g$. of imm. Mokia, S.E. Ruwenzori, $3400 \mathrm{ft}$., 11th \& 12th June. [Nos. 411, 448.R. E. D.; 3467. R. B.W.]

Adult. Iris whitish; bill and feet black.

Immature. Iris light grey; bill reddish-brown; feet dark brown.

The present series includes all stages of plumage, from the immature to the adult.

A male (No. 379) still in partially immature plumage has been marked "breeding" by Mr. Dent. Only the second primary-quill in each wing and the right-hand outer tail-feather are in the adult plumage $-i$. $e$, black with white spots.

[A few examples of the Didric Cuckoo, so called from its note, were seen on the plains at the south end of Ruwenzori and in the Upper Semliki Valley. They were breeding at the end of June. $-R . B . T$.]

\section{Chrysococcyr hlaAsi (Steph.).}

Chrysococcyx klaasi Reich. Vög. Afr. ii.p. 98 (1902); Stark \& Sclater, B. S. Afr. iii. p. 188 (1903); Sharpe, Ibis, 190\%, p. 437 [Cameroon].

a. o. Mubulku Valley, E. Ruwenzori, $6000 \mathrm{ft.}$, 1Sth Jan. [No. 1167. D. C.]

b. o imm. Mokia, S.E. Ruwenzori, $3400 \mathrm{ft}$., 21st May. [No. 2380. G. L.]

c, d. . , , , ", 1st \& 21st June. [Nos.407.R. E. D.; d.

1663. D. C.]

Iris dark brown; bill olive-green; feet green or olive-green.

[Only one specimen of Klaas' Cuckoo was seen on Ruwenzori, and was procured just below the forest-line. A few were seen in the acacia-forest at the south end. They were always very shy birds and difficult to approach. $-R . B . W$.]

\section{Chrysococcyx flavigularis Shelley.}

Chrysococcyx flavigularis Shelley, P. Z. S. 1879, p. 6r9, pl. l.; Reich. Vög. Afr. ii.p. 100 (1902): Sharpe, Ibis, 1907, p. 437 [S. Cameroon].

a. ㅇ. Mawambi, E. Congo Forest, 2500 ft., 29th Oct. [No. 575. R. E. D.]

When volume xix. of the 'Catalogue of the Birds' was written in 1891 this species was not represented in the British Museum. 'The type, a male, which was procured at Flmina, Fantee, is now in the Stuttgart Museum, and not in the British Museum as stated by Dr. Sharpe ('Ibis,' 1907, p. 437). A male was procured by Mr. Bates at the River Ja, S. Cameroon.

[The only specimen seen was obtained in the Congo Forest in an open clearing near a village. $-R . B . W$. $]$

VOL. XIX.-PART IV. No, 56.-March, 1910. 
Metallococctr smaragdineus (Swainson).

Chrysococcyx smaragdineus Shelley, Cat. Birds B. M. xir. p. 280 (1891); Stark \& Sclater, B. S. Afr. iii. p. 185 (1903).

Metallococcyx smaragdineus Reich. Vög. Afr. ii. p. 101 (1902); Jackson, Ibis, 1906, p. 527 [Ruwenzori]; Sharpe, Ibis, 1907, p. 437 [Cameroon].

a. o. Mpanga Forest, Fort Portal, 5000 ft., 20th Sept. [No. 35S8. R. B. W.]

Iris dark brown; bill light green; feet pale blue.

[The Emerald Cuckoo was seen only in the Congo Forest and in the Mpanga Forest, east of Ruwenzori. The one obtained was perched at the top of a tall dead tree and was uttering a loud shrill note. $-R . B . \mathrm{H}$.]

\section{Family TROG ON I E.}

Hapaloderma Narina (Stephen).

Apaloderma narina Reich. Vög. Afr. ii. p. 212 (1902).

Hapaloderma narina Jackson, Ibis, 1906, p. 522 [Toro]; Grant, Ibis, 1908, p. 312 [Ponthierville, Upper Congo].

r. f. Mpanga Forest, Fort Portal, 5000 ft., 14th Sept. [No. 514. R. E. D.]

Iris crimson; bill pale yellow; feet dark olive.

\section{Hapaloderma vitTatum Shelley.}

Hapaloderma vittatum Grant, Cat. Birds B. M. xvii. p. 480, pl. xvi. (1892).

Heterotrogon vittatum Reich. Vög. Afr. ii. p. 215 (1902).

a. + imm. Entebbe, $5000 \mathrm{ft} ., 12$ th Dec. [No. 1060. D. C. $]$

b. o. Mpanga Forest, Fort Portal, $5000 \mathrm{ft.}$, 16th Sept. [No. 521. R. E. D.]

Adult. Iris dark claret-colour; bill pale yellow ; feet black.

Immature. Iris dark hazel; bill black, yellow at the base and on the lower mandible; feet whitish.

[Both these species of 'Trogon were seen in the Congo and Mpanga Forests, and appeared to be rather uncommon birds. $-R . R . W$.]

Colius affixis Shelley.

Family COLIID E.

Colins leucotis affinis Reich. Vög. Afr. ii. p. 205 (1902).

Culius leucutis Sclater, in Wytsman's Gen. Ar., Picarix, pt. vi. Coliidæ, p. 5 (1906).

थ. ¿. Entebbe, $3500 \mathrm{ft}, 16$ th Nov. [No. 1001. D.C.]

b-h. o ․․ Mubuku Valley, E. Ruwenzori, $6000 \mathrm{ft}$, 3rd-20th Jan. [Nos. 63, 103. I. E. D. ; 1089. D. C. ; 2066, 2099. G. L.; 3071, 3123. IR. B. H.] 
i-l. of q. Mokia, S.E. Rumenzori, $3400 \mathrm{ft}$, 1st-17th May. [Nos. 264. R. E. D.; 1578. D. C.;3323.R. B.W.]

$m, n . \delta$ ㅇ. Mokia, S.E. Ruwenzori, $3400 \mathrm{ft}$, 1st \& 6th June. [Nos. 409, 433. R. E. D.]

Iris slate-colour (November), orange, yellow, or greenish-yellow (January, May, and June); bill dark grey, culmen and lower mandible whitish; feet coral-red or scarlet.

This species was breeding at Mokia in January.

[Shelley's Coly was plentiful on the plains all around Ruwenzori, and was alsu met with on the mountains up to the altitude where the forest-line commences, bui not higher. Unlike C. macrurus, this species usually frequents the lower bushes, especially those overgrown with a tangled mass of creepers. It is usually to be seen in small flocks. Often on the approach of danger, instead of at once taking to flight, all the birds disappear into the bush after the manner of rats or squirrels rather than birds. If the bush is beaten, they eventually come hurrying out, and, with a great whirring of wings, fly off chattering to some adjacent thick bush, into which they at once disappear headlong.- $R, B, H$.

\section{Colius macrurus (Linn.).}

Colius macrourus Reich. Vög. Afr. ii. p. 210 (1902).

Colius macrurus Jackson, Ibis, 1906, p. 522 [Toro]; Sclater in Wytsman's Gen. Av., Picaria, pt. vi. Coliidre, p. 4 (1906).

a-d. o q. Mokia, S.E. Ruwenzori, $3400 \mathrm{ft} ., 2$ di-25th June. [Nos. 1622, 1689. D. C.; 3441, 3464.R. B.W.]

$e-$ l. o ㅇ. Mokia, S.E. Ruwenzori, $3400 \mathrm{ft}$., 2nd-7th July. [Nos. 473. R. E. D. ; 1715, 1723. D. C. ; 2412, $2413,2414,2415$. G. L. $]$

Iris dark red or dark bronn (in one, violet); eyelid scarlet; bill black, base of the upper mandible and cere pink; feet pink, dull red, or dark mauve.

[A few Long-tailed Colies were seen among the acacias on the plains at the S.E. of Ruwenzori, but there they were comparatively rare birds; while further round the mountains on the S.W., in an exactly similar kind of acacia-country, they were very numerous. They were seen always in small flocks of six or eight individuals, and were usually to be found among the taller trees. 'Their note, which is quite different from that of $C$. affinis, is a long-drawn clear whistle, but is not verv loud, and is uttered when flying from the top of one tree to another. $-R . B . W$.] 
Crpselus maximus Grant.

$$
\text { Family CYYSELID.E. }
$$

Cypselus maximus Grant, Bull. B. O. C. xix. p. 56 (1907).

a. ․ Mubuku Valley, E. Ruwenzori, 12,000 ft., 30th Jan. [No. 1200. D. C.]

b. o. ", $\quad, \quad 10,000 \mathrm{ft}$, 14th Feb. [No. 154. R. E. D.]

(Types of the species.)

'This species, the largest known Swift, is most nearly allied to $C$. africanus Temm., but is much larger and darker. 'The top of the head and upperpart of the body are dark sooty-brown, with a slight oily gloss; the cheeks, car-coverts, pectoral band. and upper and under tail-coverts, as well as the outer web of the quills and the tail-feathers, are even darker, and inclining to sooty-black. 'The bill and tarsus are also proportionately longer than in C. afiriconus. Iris dark hazel; bill and feet black.

8. 'Total length cr. $8 \cdot 5$ inches; culmen from the base of the forehead $0 \cdot 78$, exposed portion 0.52 ; wing 9.0 ; tail 3.35 ; tarsus 0.8 .

. Total length ca. 8.8 inches; culmen from the base of the forehead 0.78 , exposed portion 0.5 ; wing 9.2 ; tail $3 \cdot 45$; tarsus 0.81 .

In $C$. africanus the wing-measurement is as follows:- $90,7 \cdot 9-8.1$ inches; 2 f, $7 \cdot 9-8 \cdot 3$.

[These Swifts were numerous about the higher altitudes of Ruwenzori, and great numbers were breeding in the high cliffs at $13,000-14,000 \mathrm{ft}$. They probably also breed as low down as $10,000 \mathrm{ft}$, where there are suitable cliffs. One bird was shot coming out of a crack in a cliff at $10,000 \mathrm{ft}$. in the Mubuku Valley. A large whitebellied Swift, which we believed to be of this species, was often seen on the plains near Lake Edward.-R. B. W.]

Family CAPRIMULGID $L$.

Caprimugus fossei Hartl. (Plate XIX. fig. 24, egg.)

Caprimulgus fossei Reiclı. Vög. Afr. ii. p. 365 (1902).

Caprimulyus fossei clarus Reich. t. c. p. 367.

$a-\ell$. ot et of imm. Mokia, S.E. Ruwenzori, $3400 \mathrm{ft}$., 30 th May. [Nos. 312. 313. R. E. D. ; 34 430, 3431, 3432.R. B.W.]

Iris, bill, and feet dark brown.

The young birds have the general colour of the upperparts distinctly paler and grejer than in the adult. According to Dr. Reichenow, both the subspecies mentioned above occur at Bukoba, on the W. of Victoria Nyanza; but the fact is that the so-called 
C. f. clarus is founded on younger specimens, which are paler and of smaller dimensions.

The five specimens mentioned above measure as follows :-

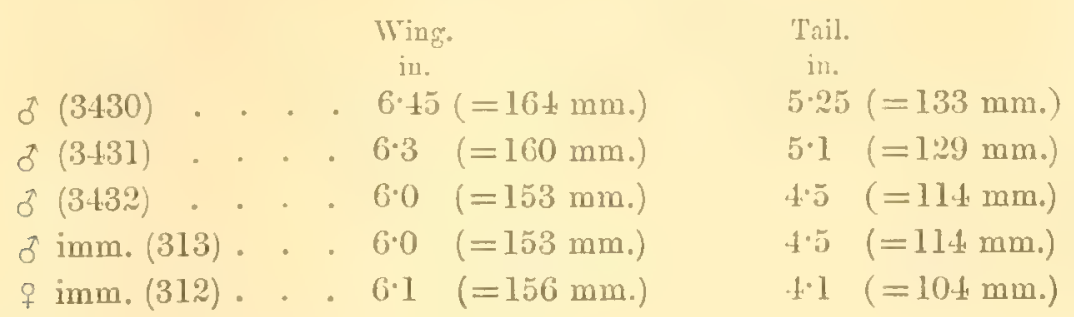

According to Dr. Reichenow, the two first-mentioned specimens should be referred to $C$. fossei and the remaining three to $C . f$. clarus.

Two eggs of this species were procured at Mokia on the 10th of July by Mr. R. B. Woosnam. They have the usual Nightjar type of coloration, and measure respectively $1.15 \times 0.8$ and $1.0 \times 0.8$ in. One example will be found figured on Plate XIX. fig. 24.

[The Mozambique Nightjar was numerous on the plains around the south end of Rurrenzori. They were often to be seen in the evenings flying in and out close to the ground among the acacia-trees. 'They were fond of settling on the euphorbiatrees to make their "jarring" cry.-R. B.W.]

\section{Caprimulgus rutwenzoril Grant.}

Caprimulgus ruwenzorii Grant, Bull. B. O. C. xxiii. p. 9.1 (1909).

a. ơ. Mubuku Valley, E. Ruwenzori, $9000 \mathrm{ft}$. 3rd March. [No. 182. R. E. D. Type of the species.]

This species is most nearly allied to C. fronatus Salvad, but is altogether darker, especially on the underparts, the belly and under tail-coverts, like the breast, being entirely barred with black and buff. 'The white spot on the inner web of the first primary is small, situated on the margin, and does not extend more than halfway across the web; the two outer pairs of tail-feathers have the terminal half white $(2 \cdot 4$ inches deep on the outer pair), the brown on the margin of the outer web extending almost to the tip; a group of buff spots on the middle of the chest. Iris dark brown; bill black; feet brown. Total length ca. 9.0 inches; wing 6.2 ; tail 4.25 ; tarsus $0 \cdot 66$.

A second male example, which is no doubt of this species, was procured in Likipia by Mr. L. C. Harwood when collecting for Lord Delamere. 'The tail of this bird is missing.

C. pectoralis Cuv., from S. Africa, is another closely allied species, but lacks the group of buff spots on the chest; it, however, resembles $C$. mwenzori in having the primary-quills from the 5th inwards black barred with chestnut.

[A few of these Nightjars inhabited an open ferny ridge on Ruwenzori at an elevation of from $8000-9000 \mathrm{ft}$. 'This species was not obtained on the plains below. $-R . B . W$. 
Capriaulgus natalexsis Smith.

Caprimulgus natalensis Reieh. Vüg. Afr. ii.p. 367 (1902); Jackson, Ibis, 1906, p. 521 [Toro] ; Grant, Ibis, 1907, p. 601 [Baro R.].

a. o . 80 miles WV. of Entebbe, 3500 ft., 2nd Dec. [No. 1029. D.C.]

b. ठ. Mokia, S.E. Ruwenzori, $3400 \mathrm{ft}$., $30 \mathrm{th}$ April. [No. 1461. D.C.]

$c, d$. ot et $q$ imm. Mokia, S.L. Ruwenzori, $3400 \mathrm{ft} ., 13$ th \& 16 th June. [Nos. 3474 , 3486.R.B.W.]

Iris dark brown; bill brown; feet flesh-colour or light brown.

These specimens agree perfectly with birds from Natal. Mr. Alexander has recently described two very closely allied species or rather subspecies of this group, viz. C. chadensis, from Lake Chad, and C. gabonensis, from Gaboon [cf. Bull. B. O. C. xxi. p. $90(1908)]$.

[The Natal Nightjar was scen near Entebbe, and a few were met with on the plains at the south end of Ruwenzori; but it was not a common bird.- $R . B . W$.

\section{Cosmetornis vexillarius (Gould).}

Macrodiptery $x$ vexillarius Reich. Vög. Afr. ii. p. 3 r 1 (1902).

Cosmetornis vexillarius Jackson, Ibis, 1906, p. 520 ['T'oro].

a. ㅇ. Mubuku Valley, E. Ruwenzori, $5000 \mathrm{ft}$, 6th March. [No.3186.R.B.W.] $b-i$. of o et $\delta$ imm. Mokia, S.E. Ruwenzori, $3400 \mathrm{ft}$., 1st-30th May. [Nos. 266, 280. R. E. D. ; 1482. D.C.; 3299, 3304, 3305, 3428, 3429. R. B.W.]

$k-y$. o 오. Mokia, S.E. Ruwenzori, $3400 \mathrm{ft} ., 13 \mathrm{th}-29$ th June. [Nos. 1645, 1659, $1664,1671,1672,1673,1674,1675,1681,1690,1695,1706,1707$. D. C. ; 3475, 3476. R. II. II.]

$z-e^{\prime}$. of of et $\delta^{*} \mathrm{imm}$. Mokia, S.E. Ruwenzori, $3400 \mathrm{ft}$., 4th-Sth July. [Nos. 474. i. d. $476,480$. R. E. D. ; 1716, 1717, 1724. D.C.]

Iris, bill, and feet dark brown.

The large series of this species collected by the Expedition includes all stages of plumage of both the male and female.

[The Pennant-winged Nightjar was extraordinarily numerous on the dry plains at the S.E. end of Ruwenzori between the foot of the mountains and Lake George. It was no uncommon sight in the evenings to see fifteen or twenty of these curiouslooking birds drifting about around the camp, performing curious antics high in the air-diving, flopping, and twisting about like Lapwings, and often looking more like tattered pieces of paper blown by the wind than anything else.

The long pennant-like feathers were just beginning to make their appearance in the first week in May. 
These Nightjars were also seen at Fort Beni and Irumu, but never in such numbers as at the south end of Ruwenzori.-R. B.W.]

Family BUCEROTID E.

Ceratogima atrata ('Temm.).

Ceratogymna atrata Reich. Vög. Afr. ii. p. 239 (1902).

a. o. Irumu, Eturi Forest, $3000 \mathrm{ft} ., 18$ th Oct. [No. 571.R.E. D.]

Iris crimson; bill dark horn-colour ; feet black.

[A few examples of the Black Hornbill were met with in the Eturi Forest.R. B. W.]

Bycanistes subquadratus Cabanis.

Bycanistes subquadratus Grant, Cat. Birds B. M. xvii, p. 419 (1892).

Bycanistes subcylindricus Reich. Vög. Afr. ii.p. 241 (1902) [part.].

a, b. o 20 miles W. of Entebbe, 25th Nov. [Nos. 9, 10.R.E. D.]

Iris dark brown; bill brown, white at the base of the casque; feet black.

Dr. Reichenow cunsiders that the W. African B. subcylindricus Sclater is founded on immature examples of $B$. subquadratus $C a b$; ; but he overlooks the fact that the type of $B$. subcylindricus, a female, is a perfectly adult bird, having lived for eight years in the Zoological Society's Gardens, Regent's Park. As stated in the description and shown in the figure (P. Z.S. 1570, p. 668, pl. xxxix.), it has the greater wingcoverts black.

In addition to the specimens from Entebbe in the present collection there are two adult birds (sex not indicated) from the same neighbourhood in the British II useum. All these four specimens have the greater wing-coverts black widely tipped with white, and at present $I$ see no reason for supposing that $B$. subquadratus is synonymous with $B$. subcylindricus, unless it can be proved that the latter is the female and the former the male of the same species. In other species of the group the plumage of the sexes is the same, and the only external difference is to be found in the shape of the casque.

['This Hornbill was plentiful throughout the journey from Entebbe to Ruwenzori, but was never seen on the mountains. It was very numerous in the Mpanga Forest to the east of Ruwenzori. When flying, its wings make almost as much noise as those of a Swan, and its vocal powers are tremendous. Three or four would sometimes perch on the top of a tall tree and hold a concert, a most extraordinary din of raucous cawings. $\left.-R, B . H_{\text {. }}\right]$ 
Count Salvadori has recently described a large Hornbill (Bycanistes aloysii) [cf. Boll. Mus. Tor. xxi. no. 542, p. 1 (1906)] procured in the neighbourhood of Entebbe by the Duke of the Abruzzi. It is said to differ from B. subquadratus in having the terminal third of the two middle tail-feathers white. I have no doubt that the middle pair of tail-feathers are missing in the specimen described, and that the second pair have been mistaken for them. In that case $B$. aloysii should be referred to the synonymy' of $B$. subquadratus.

\section{Lophoceros fasciatus (Shaw).}

Lophoceros fasciatus Reich. Vög. Afr. ii. p. 248 (1902) ; Grant, Ibis, 1908, p. 313 [Kasongo, Upper Congo].

a. ․ Fort Beni, Semliki Valley, $3000 \mathrm{ft} ., 24$ th July. [No. 3524. R. B.W.]

Iris brown; bill red and cream-colour; feet black.

\section{LOPHOCEROS MELANOLEUCUS Licht.}

Lophoceros melanoleucos Reich. Vög. Afr. ii. p. 249 (1902).

Lophoceros suahelicus Neumann; Jackson, Ibis, 1906, p. 516 [Toro].

a, b. đ。. Mubuku Valley, E. Ruwenzori, $6500 \mathrm{ft}$., 20th March. [Nos. 218, 219. li. L. I.]

c. ơ. Mokia, E. Ruwenzori, $3400 \mathrm{ft}$, 12th May. [No. 1552. D. C.]

Iris pale yellow or pale cream-colour; bill red, with a margin of yellow at the base ; feet black.

[A few examples of the White-and-Black Hornbill were seen up to $6500 \mathrm{ft}$., but the? were only stray risitors from the plains below.-R. $I$. $I W$.]

\section{Family UPUPID $\mathbb{E}$.}

Upupa africana Bechst.

Upupa africana Reich. Vögo. Afr. ii. p. 336 (1902).

«. q. Mokia, S.E. Ruwenzori, 3400 ft., 5th May. [No. 2333. G. L.]

Iris dark brown; bill black; feet grey.

[No other example of the African Hoopoe was seeu.- R. B.W.]

InRISOR VIRIDIS Licht.

Irrisor viridis Grant, Ibis, 1902, pp. 433, 434.

Irrisor erythrorynchos viridis Reich. Vög. Afr. ii. p. 340 (1902).

a. ․ Mokia, S.E. Ruwenzori, $3400 \mathrm{ft} ., 2$ nd May. [No. 267. R. E. D.]

Iris dark brown; bill and feet red. 
This specimen appears to belong to the smaller shorter-tailed South African form of $I$. erythrorhynchus (Lath.), but the white wing-band is somewhat wider, as in specimens from Swaziland (cf. 'Ibis,' 1902, p. 434). Specimens collected by Doggett at Mulema, S. Uganda, are typical long-triled examples of I. erythrorhynchus (cf.' Grant., 'Ibis,' 1905, p. 209).

[The Lesser Red-billed Wood-Hoopoe was shot among the acacia-trees on the plains at the south-east end of Ruwenzori.- $R . B . H$.

IrRTSOR JACKSONI Sharpe.

Irrisor jucksoni Reich. Vüg. Afr. ii. p. 313 (1902); Jackson, Ibis, 1906, p. 517 [Toro].

a. J imm. Mpanga Forest, Fort Portal, $5000 \mathrm{ft} ., 15$ th Sept. [No. 519. R. E. D.]

b. o. 30 miles N. of Fort Beni, Semliki Valley, 3900 f., 12th Aug. [No. 1766. 1.. ('.]

Iris dark hazel; eyelid red; bill and feet red.

[Jackson's Wood-Hoopoe was often seen in the Eturi Forest and in the Mpanga Forest, enst of Ruwenzori. It was generally seen in flocks of a dozen or more individuals, climbing about high up in the trees.- $K . B . W$.]

\section{Rinnopomastus schalowi Neumann.}

Rhinopomastus cyanomelas schalowi lieich. Vüg. Afr. ii. p. 347 (1902).

Rhinopomastus schalowi Jackson, Ibis, 1906, p. 517 [Toro].

๙. +. Mokia, S.E. Ruwenzori, $3400 \mathrm{ft}$, 26th April. [No. 1438. D. C.]

$b-m$. of $q$ et $\delta \mathrm{imm}$. Nokia, S.E. Ruwenzori, $3400 \mathrm{ft}$., 3rd-31st May. [Nos. 275 , 305, 311, 398. R. E. D.; 1599. D. C. ; 2328, 2386. G. L. ; 3334, 3335̄, 3390, 3391 li. li. H.]

u. ơ. Mokia, S.E. Ruwenzori, $3400 \mathrm{ft} ., 2$ nd June. [No. 3410. R. B. W.]

Iris dark brown; bill and feet black.

All the abore specimens, with the exception of No. 311, are typical $R$. schalowi, with a broad white subterminal bar on the outer tail-feathers. In No. 311, which is a female, the white subterminal markings on the two outer pairs of tail-feathers are much reduced, being merely spots of white. This bird is therefore a typical example of $R$. cyanomelas (Vieill.) from S. Africa, and should perhaps be referred to that form.

[Schalow's Wood-IIoopoe was very plentiful in the acaciaforest on the plains pround the south end of Ruwenzori; but it was never seen on the mountains.li. B. H.] 
Family MEROPID E.

Melittopinagus oreobates Sharpe.

Melittophagus oreobates Sharpe, Ibis, 1892, p. 320 [Mt. Elgon]; Reich. Vög. Afr. ii. p. 303 (1902); Jackson, Ibis, 1906, p. 518 [Ruwenzori].

a. ․ Luimi Valley, N.E. Ruwenzori, 5000 ft., 29th Sept. [No. 3619. li. B. II:]

b. J. Mubuku Valley, E. Ruwenzori, $6000 \mathrm{ft}, 29$ th Dec. [No. 1070. D. C.]

$c$, d. ㅇ et of vix ad. Mubuku Valley, E. Ruwenzori, 6000-7000 ft., 5th \& 9 th Jan. [Nos. 79.R. E. D.; 1101. D. C. ]

e,f. ․ Mubuku Valley, E. Ruwenzori, 6000-7000 ft., 8th \& 16th Feb. [Nos. 2149, 2156. G. L.]

Iris crimson or dark red; bill black; feet brown, olive.brown, or grey.

'I'wo eggs were taken by Mr. Gerald Legge from a nest in a hole in a bank in the Mubukn Valley on the 16th of February and the female bird (No. 2156) was shot off the nest. 'They are of the usual rounded oval type, very glossy, and pure white. 'They measure $\cdot 9 \times \cdot 75, \cdot 9 \times \cdot 76$ inch.

[A few Cinnamon-breasted Bee-eaters were seen along the lower slopes of E. Ruwenzori and were occasionally met with up to an altitude of $8000 \mathrm{ft}$. 'They were not very plentiful. $-R . B . W$. $]$

\section{Melittophagus Meridionalis Sharpe.}

Melittophagus meridionalis Sharpe, Cat. Birds B. M. xvii. p. 45, pl. i. fig. 4 (1892); Reich. Vög. Afr. ii. p. 307 (1902); Jackson, Ibis, 1906, p. 518 [Toro].

a,b. o. 80-100 miles W. of Entebbe, 3500-4100 ft., 1st \& 4th Dec. [Nos. 1020, 1033. D. C.]

c. ․ Mubuku Valley, E. Ruwenzori, $5000 \mathrm{ft}$, 14th Mar. [No. 2195. G. Is.]

d. Ad. $", \quad " \quad 4$ th April. [No. 228. K. L. L)]

$e-l$. o $q$ et $q$ imm. Mokia, S.E. Ruwenzori, $3400 \mathrm{ft.}$ 2nd-18th May. [Nos. $2363,2364,2366$. G. L. ; 3306, 3307, 3308, 3360.-R. B. W.

$m-q . o^{n}$. Mokia, S.E. Ruwenzori, $3400 \mathrm{ft}$, 2nd-14th June. [Nos. 414, 41s, 430. R. E. IJ.; 2399, 2400. G.J.]

Adult. Iris dark red or crimson; bill black; feet dark grey, brown, or black.

Immature. Iris brown; bill black; feet brown or grey.

[This Bee-eater was seen near Entebbe and was plentiful around Ruwenzori, but was never met with above an altitude of $6000 \mathrm{ft}$. It was very numerous at the south end of the range. $-R . B . H$. 


\section{Merops albicollis Vieill.}

Aerops albicollis Reich. Vög. Afr. ii.p. 317 (1902); Jackson, Ibis, 1906, p. 518 [Toro].

a, b. of. Entebbe, $3500 \mathrm{ft} ., 19$ th Nov. [Nos. 2002, 2003. G. L.]

c. ơ. 80 miles W. of Entebbe, $3500 \mathrm{ft}$. , 2nd Dec. [No. 1026. D. C.]

Iris scarlet or dark red; bill black; feet brown or dirty yellow.

It is difficult to understand for what purpose Dr. Reichenow has followed Reichenbach and separated this species generically from Merops; even the character said to be found in the slight difference in the shape of the wing is not constant.

Merops apiaster Linn.

Merops apiaster Reich. Vög. Afr. ii.p. 320 (1902).

a. of imm. 90 miles W. of Lntebhe, 3800 ft., 3rd Dec. [No. 24. R. E. D.]

b. o imm. Luimi Valley, N.E. Ruwenzori, $6000 \mathrm{ft}$, 1st Oct. [No. 3622. R. R. W.]

Iris crimson $(a)$, pale chestnut $(b)$; bill black ; feet brownish-black.

Both these immature birds are in somewhat worn plumage. In specimen $a$ many of the adult chestnut feathers of the mantle are partially grown, but are still mostly concealed by the green plumage characteristic of immaturity.

[A few examples of the Common Bee-eater were seen near Entebbe, and a small flock was met with in the Luimi Valley on Ruwenzori at an altitude of $6000 \mathrm{ft}$ - li. B. II.]

\section{Mrrops persicus Pall.}

Merops persicus Reich. Vög. Afr. ii. p. 322 (1902); Jackson, Ibis, 1906, p. 518 [Toro].

a. ㅇ. Mokia, S.E. Ruwenzori, $3400 \mathrm{ft}$., 22nd April. [No. 2282. G. L.]

b. 3 imm. " , 19th May. [No.3386.R.B.H.]

Iris dark brown; bill and feet black.

No. 2282 is a fine specimen almost entirely in freshly moulted plumage. No. 3386 is probably the young of this species, but in some respects it nearly approaches 11. superciliosus, and may be the result of interbreeding.

\section{Merops superchiosus Lim.}

Merops superciliosus Reich. Vög. Afr. ii. p. 325 (1902).

a-d. of o. Mokia, S.E. Ruwenzori, $3400 \mathrm{ft}$., 3rd-24th May. [Nos. 1618. D. C. $2320,2323,2376$. G. L.]

$\ell^{\prime}-$ g. o 9 . Mokia, S.E. Ruwenzori, $3400 \mathrm{ft} ., 7$ th-18th June. [Nos. 437, 471. I. E. D.; 2397. G. L.]

Iris scarlet or dark crimson; bill black; feet grey.

No. 2376, though in most respects a typical example of the present species, has the 
white superciliary stripe tinged with greenish-blue and the crown mixed with feathers of a similar colour; possibly this colour is due to wear alone, as the greenish feathers are all in a worn condition, while the new and partially grown feathers are olive-brown. It would be interesting to know to what extent, if at all, this species interbreeds with the closely allied $M$. persicus.

Euristouus afer (Lath.).

Family CoRACIID

Eurystomus afer Reich. Vög. Afr. ii.p. 228 (1902).

a, b. o f. Fort Beni, Semliki Valley, 3000 ft., 24th July. [Nos. 497.R.E. D.; 1752. D. C.]

Iris dark brown; bill yellow; feet grey or dark olive-green.

Wing: of $169 \mathrm{~mm}$., ㅇ $172 \mathrm{~mm}$.

Eurstowus Rufobuccalis Reichenow.

Eurystomus rufobuccalis Reich. Vög. Afr. ii. p. 231 (190:2).

a, b. o ․ 60 miles W. of Entebbe, $3700 \mathrm{ft}$. , 29th Nov. [Nos. 1071. D. C.; 2012. G. L.]

c. ठ*. 80 miles W. of Entebbe, $3500 \mathrm{ft}$., 3ird Dec. [No. 2016. G. L.]

This form is easily distinguished from $E$. afer by having the rump and median upper tail-coverts chestnut-brown like the back, instead of blue; while the underparts lack the dark shafts to the feathers which form rather a conspicuous character in $E$. afer.

'The wing measures:- 0 181-182 mm.; 우 $178 \mathrm{~mm}$.

\section{Family A L CEDIXID X.}

Halcyon chelicutersis (Stanley).

Halcyon chelicuti Reich. Vög. Afr. ii. p. 271 (1902).

Halcyon chelicutensis Jackson, Ibis, 1906, p. 516 [Toro]; Grant, Ibis, 1908, p. 315 [N.W. of Lake Tanganyika].

a. ơ. Mokia, S.E. Ruwenzori, $3400 \mathrm{ft} ., 1$ st May. [No. 2310. G. L.]

b,c. oㅇ. ",$\quad$ "1st \& 22 nd June. [Nos. 1666. I). C.; 3435. R. B. H.]

Iris dark brown; upper mandible dark red in the male, black in the female, lower mandible red; feet red.

[The Striped Kingfisher was plentiful on the plains round the south end of Ruwenzori. It seems to prefer the dry acacia-country to the streams or lakes.li. B. II.] 


\section{HaLCYON SEMICARULEL'S (Forsk.).}

Hulcyon semicceruleus Reich. Vög. Afr. ii, p. 276 (1902).

Hulcyon semicaruleus centralis Neumann, J. f. O. 1905, p. 190.

Hulcyon centralis Jackson, Ibis, 1906, p. 516 [Toro].

a. 9. Mokia, S.E. Ruwenzori, 3400 ft., 28th April. [No. 2298. G. I.]

J, c. ot et $\mathrm{imm}$. Mokia, S.L. Ruwenzori, $3400 \mathrm{ft}$, 22nd \& 23rd May. [Nos. 361. R. E. I). ; 1478. D. C.]

d. ㅇ. Mokia, S.E. Ruwenzori, $3400 \mathrm{ft}$, 16th June. [No.460.R. E. D.]

Alult. Iris dark brown; bill and feet red.

Immature. Iris dark brown; bill brown; feet chocolate.

[The African White-headed Kingfisher was plentiful on the plains at the south end of Ruwenzori, and was always seen among the dry acacia-country.- $R . H . H$.]

\section{Hatcron palidiventris Cab.}

Halcsun pallidiventris Sharpe, Cat. Birds B. M. xvii. p. 235 (189?).

Halcyon swainsoni Reich. (nec Smith) Vüg. Afr. ii. p. 278 (1902).

H. s. swerinsoni Neumann, J. f. O. 1905, p. 190.

Halcyon semiccerulens hyacinthinus lieich.; Neumann, J. £. O. 1905, p. 190.

a. 8. Mokia, S.E. Ruwenzori, 3400 ft., 10th May. [No. 2358. G. L.]

b. 0 . Fort Beni, Semliki Valley, 3000 ft., 24 th July. [No. 175t. D. C.]

Iris dark brown; bill and feet red.

It must be evident to anyone who has read Smith's original description of IIalsyon swainsoni (cf. S. Afr. Quart. J. 1834, p. 143) that Dr. Reichenow is wrong in uniting that bird with 11 . pullidiventris Cab. Smith writes that the "back, middle of the wing, and tail are blue with a green gloss" in $I$. swcinsoni, wherens in the present form they are deep hyacinth-blue or purplish-blue. H. swainsoni is said to have been procured in the interior of South Africa, a sumewhat vague locality.

\section{Halcton senegalexsis (Limn.).}

Halcyon senegalensis Sharpe, Cat. Birds I. M. xvii. 1. 212 (1902); Reich. Vög. Afr. ii. p. 28\% $(190: 2)$.

$a-g$. of $q$ et of $q$ imm. Mokia, S.E. Ruwenzori, 3400 ft., 4th-23rd Maty. [Nos. 309, 359, 360. R. E. D.; 1494, 1502, 1518, 1570. D.C.]

h. ․ Nokia, S.E. Ruwenzori, $3400 \mathrm{ft}$, 7 th June. [No. 438. R. L. D)]

i. ค. Fort Beni, Semliki Valley, 3000 ft., 21st July. [No. 4S6. R. E. D.]

Iris dark brown; upper mandible red, lower black; feet black.

The Senegal Kingfisher was plentiful in the acacia-forest on the plains around the south end of Ruwerzori and was seen at Fort Beni on the edge of the Fituri Forest. It was never found near water, but seemed to frequent only the rather dry country covered with acacia-trees. It has a curious loud trilling note, dificult to describe.R. B.T.] 
Halcion CTANoLeucus (Vieill.).

Halcyon cyanoleucus Sharpe, Cat. Birds B. M. xvii. p. 245 (1892); Reich. Vög. Afr. ii. p. 284 (1902).

a. $\sigma^{*} \mathrm{imm}$. Mokia, S.E. Ruwenzori, $3400 \mathrm{ft.}, 25$ th A pril. [No. 1430. D. C.]

b. $\mathrm{imm}$. " , " 20th May. [No.351. R. L. D.]

Iris hazel or dark brown; upper mandible red, lower black (red at the base in the younger bird); feet black.

This species closely resembles $H$. senegalensis, and occurs side by side with it over the greater part of its range. It has been distinguished by its bluish head and larger size, but, curiuusly enough, the character by which it is most easily distinguished, viz. the black band behind the eye, has of recent years been lost sight of, though mentioned and figured by Dr. Sharpe [Mon. Alced. p. 189, pl.69 (1869)]. It is a very constant character and found in the young as well as in the adult birds.

\section{Halcyon badius Verr.}

Halcyon badius Reich. Vög. Afr. ii. p. 285 (1902).

a. o imm. 20 miles N. of Fort Beni, Semliki Valley, $3000 \mathrm{ft} ., 11$ th Aug. [No. 7.7. I). C.]

Iris dark hazel ; bill red; feet dark reddish-brown.

\section{IspidiNa PICTA (Bodd.).}

Ispidina picta Reich. Vög. Afr. ii. p. 286 (1902); Jackson, Ibis, 1906, p. 516 [Toro].

a. o imm. Mokia, S.E. Ruwenzori, $3400 \mathrm{ft}, 20 \mathrm{th}$ April. [No. 2304. G. L.]

$b-f$. o f et of imm. Mokia, S.E. Ruwenzori, $3400 \mathrm{ft}$, 1st-24th May. [Nos. 1475, 1606. D. C. ; 231 j, 2389. G. L. ; 3406. R. B. H.]

Adult. Iris dark hazel; bill and feet red.

Immature. Iris dark brown; bill black; feet salmon-pink.

The little Rose-cheeked Kingfisher was not uncommon along the edge of Lake Fidward and was also often to be seen in the dry acacia-country.- R. B. IV. 7

Mrioceyx RUficeps (Hartl.).

Myiuceyx ruficeps lecich. Vög. Afr. ii. p. 289 (1902); Grant, Ibis, 1908, p. 315 LPonthierville, Upper Congo].

a. o. Arakubi, E. Congo Forest, $2500 \mathrm{ft} ., 1$ st Nov. [No. 3654.R. B. II.]

Iris dark brown; bill and feet scarlet.

['The small Chestnut-headed Kingfisher was met with in the forest, but not in the vicinity of water.- $-R . B . W^{r}$.] 
Corythornis cranostiǵasa (Rüpp.).

Corythornis cyanostigma Reich. Vög. Afr. ii. p. 289 (1902).

$a-e . \sigma^{7}$. Mokia, S.E. Ruwenzori, $3400 \mathrm{ft} ., 25$ th-28th June. [Nos. 1682, 1683, 1702, 1703, 1704. D. C.]

[The Malachite-crested Kingfisher was plentiful along the edge of Lake Edward. It was also often seen in the dry acacia-country.- $R . B ., H$.

Cerple rudis (Linn.).

Ceryle rudis Reich. Vög. Afr. ii. p. 295 (1902).

«, b. o . Mokia, S.E. Ruwenzori, $3400 \mathrm{ft} ., 29$ th April. [Nos. 3291, 3292. R. B. II.]

Iris dark brown; bill and feet black.

[The Pied Kingfisher was very numerous on Lalse Edward and on the Semliki River. - R.B.W.]

\section{Family PSITTACIDE.}

AGAPORNIS PULlaRIES (Linn.).

Agapornis pullarius Reich. Vög. Afr. ii. p. 21 (1902); Jackson, Ibis, 1906, p. 514 [Toro]: Sharpe, Ibis, ]907, p. 428 [Cameroon].

a. 3. 30 miles W. of Entebbe, 3800 ft., 26th Nov. [No. 1011. D. C.]

b-e. of 9. Mokia, S.E. Ruwenzori, $3400 \mathrm{ft}$, 18th-29th May. [Nos. 350, 38т. R. E. D. ; 2365. G. L.; 3427.R.B.W.]

Iris dark brown or black; bill pink, red, or scarlet; feet grey or pale greenish-grey.

[We did not see this Love-Bird on Ruwenzori, though it was plentiful at Lntebbr: and a few were seen at the foot of the mountains at the south-east. It was generally met with in small parties of from six to a dozen individuals. $-R . R . M$. ]

Peocephalus aubryanus (Souancé).

Poicephalus gulielmi aubryanus Reich. Vög. Afr. ii. p. 10 (1902).

a. o. Mawambi, E. Congo Forest, $3000 \mathrm{ft}$, 28th Oct. [No. 574. R. E. I\%.]

Iris orange; bare skin on the face yellow; bill and feet black.

[One example of the Congo Parrot was obtained in the forest to the west of Mawambi. Very few examples of this species were seen, but the common Grey larrot (Psittacus crithacus) swarmed throughout the forest. $-R . B . H$.]

Pqeocephalus reichenowi Neumann.

Poicephalus meyeri reichenowi Reich. Vög. Afr. ii. p. 14 (1902).

Proocephalus saturatus Sharpe, Bull. B. O. C. xi. p. 67 (1901) [N. Anlioli]. 
a, b. o 오. 70 miles W. of Entebbe, 3600 ft., 30th Nov. \& 1st Dec. [Nos. 2013. (i. I.. : 3020). li. li. II.

$c-f$. of et of $q$ imm. Mokia, S.E. Ruwenzori, $3400 \mathrm{ft}, 4$ th-22nd Mlay. [Nos. 283, 357. R. E. D.; 1497, 149S. D. C.]

$g-i$. o et $8 \mathrm{imm}$. Mokia, S.E. Ruwenzori, $3400 \mathrm{ft}$, 19 th June. [Nos. 1647, 16ts, 1649. D. C.]

Iris orange or red; bill and feet black or grey.

$P$. reichenowi is at best a poor subspecies of $P$. meyeri (Cretzsch.), the upperparts being, as a rule, somewhat darker brown than in Abysinian specimens.

Dr. Reichenow admits no less than five subspecies of $P$. meyeri; but of these, two nt least, $P . m$. virescens Reichenow and P.m. matschiei Neumann, are, in my opinion, indistinguishable from typical examples of $P$. meyeri from Sennar. I think that in $P$. transvaclensis and $P$. damarensis the lower back and rump are always bluer than in P. meyeri, irrespective of season ( $c f$. remarks by Mr. Boyd Alexander, 'Ibis,' 1900 , p. 429).

In two quite freshly moulted males of $P$. reichenowi (Nos. 283 and 357), killed in May, the lower back, rump, and upper tail-coverts are bright grass-green like the breast and belly. As the plumage becomes worn these parts become bluer, as is clearly shown by the series before me, which includes specimens procured in June, August, November, and December.

[Reichenow's Parrot was seen throughout the journey from Entebbe to Ruwenzori; it was not seen on the mountains, but was plentiful in the acacia-country at the south end of the range and in the Semliki Valley.

This Parrot was never very easy to approach, as it was always careful to fly out on the opposite side of the tree, usually defeating its pursuers. Its flight is straight and extremely swift. $-R . B . W$.

\section{Family BUBOXID $E$.}

Strotum suaitelicum Reich.

Symium woodfordi var. suahelicum Reich. Vög. Afr. i. p. 669 (1901).

a. q. Mubuku Valley, E. Ruwenzori, $6000 \mathrm{ft}$, 5th Jan. [No. 3073. R. B. W.]

Iris dark hazel; bill and feet yellow.

[One example of this eastern form of Woodford's Owl was procured on Ruwenzori at an altitude of about $7000 \mathrm{ft}$., where the bamboo and forest intermingle; but it must be a rare bird on the mountains. $-R . R . M$. $]$

Glauciniua perlatum (Vieill.).

Glaucidium perlatum Reich. Vög. Afr. i. p. 6rt (1901) ; Grant, Ibis, 1908, p. 315 [N.W. of Lake Tangangika?. 
a. of. Mokia, S.E. Ruwenzori, $3400 \mathrm{ft.,}$ 12th June. [No. 2395. G. L.]

Iris light yellow; bill yellowish-green; feet yellow.

[A few examples of this Pigmy Owl inhabited the acacia-country around the south end of the range, but they were by no means common. I only once heard their curious note, which is a succession of whistles forming an ascending scale with equal intervals. $-R . B . H$. $]$

Bubo Lacteus (Temm.).

Bubo lacteus Reich. Vög. Afr. i. p. 650 (1901).

a. o. Mokia, S.E. Ruwenzori, $3100 \mathrm{ft}$, 6th May. [No. 1511. D. C.]

Iris black; bill pale horn-colour; feet grey.

[A few examples of Verreaux's Lagle-Owl were seen in the acacia-forests on the plains to the south-east and sonth-west of Ruwenzori.- $R . B . H$.

Family FALCONIDE.

ELines Caruleds (Desf.).

Elanus cceruleus Reich. Vög. Afr. i.p. 615 (1901).

a. ㅇ. Mokia, S.E. Ruwenzori, $3400 \mathrm{ft}$., 26th June. [No. 1694. D. C.]

The Black-shouldered Kite has the iris orange-red, the bill black, and the cere and feet yellow.

Milves egrytius (Gmel.).

Milvus agyptius Reich. Vög. Afr. i. p. 609 (1901).

a. o imm. Mubuku Valley, Ji. Ruwenzori, 22nd Jan. [No. 124. R. E. D.]

b. $0 \quad " \quad, \quad$ Sth Feb. [No. 150.R.E. D.]

Adult. Iris dark brown; bill and feet yellow.

Immature. Iris dark brown; base of the upper mandible and the lower mandible yellow, rest of the upper mandible dark brown; feet yellow.

[The Egyptian Kite was numerous on the plains around the mountains, but more so on the east side than on the rvest. It was met with up to an altitude of $7000 \mathrm{ft}$., but was not observed above that elevation. On the Tth of March, on the east side of the mountains, a great company of Kites, not less than 300, was seen in the evening. They were circling round and round, high in the air, like liooks, and travelling towards the north. On the 10th of Angust, on the west side of the range, a similar sight was witnessed, and the birds were again trarelling in a northerly direction. $-R . B, W$.

Helotarses echedatus (Daud.).

Helotarsus ecaudatus Reich. Vö̀r. Afr. i. p. 598 (1901).

a. o . Mokia, S.L. Ruwenzori, $3400 \mathrm{ft}$., 9th June. [No, 441.R. E. D.] rol. Xix.-part IT. No. 5S.-MIarch, 1910. 
Iris chestnut; cere orange; bill orange-yellow, tip lark horn-colour ; feet orange.

[The Bateleur Eagle was occasionally seen on the lower slopes and on the plains below the mountrins. 'The one obtained was shot by Mr. Dent with a small-bore rifle while it was soaring at an altitude of some $400 \mathrm{ft}$. in the air. $-R . B . H$.]

\section{LOPHOAËTUS OCCIPITALIS (Daud.).}

Lophoaëlus occipitalis Reich. Vög. Afr. i. p. 582 (1901).

๙. ․ Mubuku Valley, E. Ruwenzori, $6000 \mathrm{ft}$, $20 \mathrm{th}$ March. [No. 1392. D. C.]

Iris dark yellow; cere yellow; bill horn-blue, blackish at the tip ; feet yellow, claws black.

[The Black-crested Eagle was occasionally seen on Ruwenzori up to an altitude of $10,000 \mathrm{ft} .-R . B . W$.

\section{Buteo AUgur (Rüpp.).}

Buteo augur Reich. Vög. Afr. i. p. 592 (1901); Jackson, Ibis, 1906, p. 512 [Entebbe; Toro]; Grant, Ibis, 1908, p. 315 [Mufumbiro Volcanoes].

a. ․ Mubuku Valley, E. Ruwenzori, $6000 \mathrm{ft}$., 9th March. [No. 3191. R. B. W.] Iris brown; bill dark grey; cere yellow; feet yellow.

[The Augur Buzzard was not met with above an altitude of $7000 \mathrm{ft} .-R . B . T$. ]

\section{Buteo auguralis Salvad.}

Buteo auguralis Reich. Vög. Afr. i. p. 593 (1901).

a. of imm. Mubuku Valley, E. Ruwenzori, $6000 \mathrm{ft}$, 4th Jan. [No. 1092. D. C.] b, c. ㅇ imm. " " , $\quad$, 6000-7000 ft., 11th Feb. [Nos. 2153. G. L. ; 3162. R. B. W.]

Iris hazel (male) or whitish (female); bill black, horn-blue at the base; feet yellow. [The Lesser Augur Buzzard was not uncommon on Ruwenzori up to an altitude of $8000 \mathrm{ft}$, and was occasionally seen up to an elevation of $12,500 \mathrm{fc}-R, B . W$. $]$

\section{Buteo desertorum (Daud.).}

Buteo desertorum Reich. Vög. Afr. i. p. 59. (1501); Jackson, Ibis, 1906, p. 512 [Ruwcnzori; Toro].

a. $q$ vix ad. Mubuku Valley, E. Ruwenzori, $5000 \mathrm{ft}, 24$ th March. [No. 1417. D. C.]

Iris dark yellow; bill black; cere yellow; feet yellow.

In this example of the African Buzzard the wing measures 13.4 inches ( $=340 \mathrm{~mm}$.). The tail is greyish-brown tinged with rufous and has nine dark cross-bars; in the fully mature bird the tail-feathers are chestnut with indistinct bars. 
Metierax gabar (Daud.).

Micronisus gabar Reich. Vög. Afr. i. p. 565 (1901).

u. o imm. Mokia, S.E. Ruwenzori, $3400 \mathrm{ft} ., 18$ th May. [No. 342. R. E. D.]

The Red-faced Goshawk has the iris yellow, the bill black, the cere yellow, and the feet red.

Cincus macrunus (Gmel.).

Circus macrourus Reich. Vüg. Afr. i. p. 535 (1901).

थ. $\delta$ imm. 120 miles W. of Entebbe, 4000 ft., 9th Dec, [No. 2026. G. L.]

Iris light yellow; bill black; feet yellow.

An immature example of the Long-tailed Harrier with the entire underparts pale fawn-colour.

Accipiter Melayoleucus Smith.

Astur melanoleucus Reich. Vög. Afr. i. p. 551 (1901).

a. ․ Mubuku Valley, E. Ruwenzori, 6000 ft., 24th Feb. [No. 1263. D. C.]

Iris light brown; cere yellow; bill black, light blue-grey at the base; feet yellow.

A fine adult example of this giant Sparrow-Hawk, which is an extremely rare bird in the mature plumage.

[The Great Black-and-White Sparrow-Hawk is a rare bird ou Ruwenzori. A pair was often seen in the Mubuku Valley, flying about over the forest, or just below it.R. B. $[W$.

$$
\text { Family A X A T I D E. }
$$

ANAS SPARSA Lyton.

Anas sparsa Reich. Vög. Afr。 i. p. 115 (1900).

थ. ठ゚. Mubuku Valley, E. Ruwenzori, 10,000 ft., 1st, Feb. [No. 3144. R. I3. W.]

Iris dark brown; bill pinkish-white, mottled with black; feet orange.

[The Black Duck was occasionally seen on the larger rivers on Ruwenzuri up to an elevation of $12,000 \mathrm{ft}$. In January one or two pairs were breeding in a broad swampy part of the Mubuku Valley at about 10,000 ft.-R. B. W.]

Querquedula circia (Linn.).

Anas querquedula Linn.; Reich. Vög. Afr. i. p. 121 (1900).

Querquedula circia Salvad. Cat. B. 13rit. Mus. xxvii. p. 293 (1895).

«. ơ. Fort Portal, Uganda, 5000 ft., 5th March. [No, 2176. G. L.]

Iris hazel; bill black; feet slate-grey.

[The Garganey was met with only on a small crater-lake near Fort Portal, where it was not very common. $-R, B . W$.] 
Sarcidiornis melanonota (Pennant).

Sarlidiornis melanotus Reich. Vög. Afr. i. p. 129 (1900).

a. ㅇ. Fort Portal, Uganda, $5000 \mathrm{ft} .$, 1st July. [No. 34.97. R. B. W.]

Iris dark brown; bill black; feet grey.

[A flock of about twenty examples of this Comb-Duck was seen on a small craterlake near Fort Portal. 'This was the only occasion upon which they were met with.li. I. II:?

\section{Family OTI D I $₫$.}

Lissotis Mielanogaster (Rüpp.).

Otis melanogaster Reich. Vög. Afr. i. p. 256 (1900) [part.].

Lissotis melanogastra Obcholscr, Proc. U.S. Nat. Mus. xxviii. p. 836 (1905).

Lissolis lovati Grant, Ibis, 1302, p. 453, pl. xi. \& text-fig. 10.

a, b. o ․ 12 miles $W^{r}$. of Entebbe, $3500 \mathrm{ft}$, 24th Nov. [Nos. 1009. D. C.; 3003. R. B. $H$.

When separating the southern black-winged form of Lissotis from the Abyssinian species, L. melanogaster (Rüpp.), by an unfortunate orersight I renamed the Abyssinian bird $L$. lovati. This mistake was pointed out by Mr. Oberholser, who has now named the southern black-winged form $L$. notoplitl .

[A few examples of the White-winged Bustard were met with on the plains around the south end of Ruwenzori, but they were rather uncommon. A pair was also seen near Entebbe.-R. B. W.]

$$
\text { Fumily CE D C N E M I D .. }
$$

Gedcreacus veruiculates Cabanis. (Plate XIX. fig. 17, eggr.)

Edicnemus vermiculatus Reich. Vög. Afr. i. p. 200 (1900).

a,b. o ․ . Mokia, S.E. Ruwenzori, 3400 ft., 26th May. [Nos. 341S, 3419. R. B. W.]

Iris pale yellow, speckled with brown; bill black, yellow at the base; feet pale dirty yellow.

An egg of this species procured by Mr. Woosnam is much like that of $E$. cedicnemus (L.). It is of a slightly pointed oval shape and almost devoid of gloss. The groundcolour is palc buff, heavily blotched and spotted with dark brown markings, which form it partial ring round the larger end, and there are underlying small spots of lilac-grey. It measures $1.9 \times 1.32$ inch.

[A few examples of the Vermiculated Thick-knee were met with on the plains around the south end of Ruwenzori, and a nest containing a single ego was found among the gravel on the shores of a small salt-lake at Kikerongo, S.E. Rurrenzori.II. T3. IV.] 


\section{Family PARRID}

\section{Pinllopezos arricanus (Gmel.).}

Actophilus africanus Reich. Vög. Afr. i. p. 267 (1900).

a. o . Entebbe, 3000 ft., 15th Nor. [No. 2001. G. L.]

Iris dark hazel; upper mandible slate-blue, lower mandible darker; feet slate-blue.

[The African Jacana was seen on Victoria Nyanza and on a small crater-lake near Fort Portal. $-R . B . W$.

\section{Family GLAREOLID.}

\section{Glareola pratincola (Linn.).}

Glareola fusca (Linn.); Reich. Vög. Afr. i. p. 144 (1900).

$a-a$. o ․ 'Mokia, S.E. Ruwenzori, 15th June. [Nos. 3481, 3482, 3483, 3484. R. B. W.]

Iris dark brown; bill black, red at the gape; feet dark brown.

[Great numbers of Pratincoles frequented the open shores of a small salt-lake at the south-east end of Ruwenzori in June and the early part of July. $-R . B . W$.

Galactochrysada emini (Shelley).

Glareola emini Reich. Vög. Afr. i. p. 147 (1900).

a. o. Fort Beni, Semliki Valley, $3000 \mathrm{ft.,}$ 19th July. [No. 481. R. E. D.]

Iris dark brown; bill black, red at the base; feet red.

[Numbers of Emin's Pratincole were seen flying up and down over the rapids on the Semliki River. 'The species was met with again on the Aruwimi River, near its junction with the Congo. - R. B.W.]

\section{Family C H A R A R I D E.}

LomivaNelius Lateralis (Smith).

Lobivanellus lateralis Reich. Vög. Afr. i. p. $19 \pm$ (1900).

a. ․ . Mokia, S.E. Ruwenzori, $3100 \mathrm{ft} ., 12 \mathrm{th}$ June. [No. 450. R. E. D.]

Iris stone-colour; eyelids yellow; wattles yellow, red at the tip; bill yeliow, tip black ; feet yellow.

[A few examples of this Wattled Lapwing were seen around the shores of Lake George and anong the native cultivations. $-R . l 3 . W$.

STEPIANILYx noRyatus Swainson.

Stephanibyx inornatus Reich. Vög. Afr. i. p. 179 (1900); Grant, Ibis, 1905, pp. 203, 21:2 [Mulema, S. Uganda]; Jackson, Ibis, 1906, p. 509 ['T'oro]. 
a,b. ․ Mokia, S.E. Ruwenzori, 3400 ft., 2nd-5th May. [Nos. 1480, 1505. D. C.] Iris pale yellow; bill and feet black.

[This Plover was occasionally scen on the plains near Lake Edward.-R. B. W.]

'Totaxus ochropus (Limn.).

Totanus ochropus Reich. Vüg. Afr. i. p. 222 (1900).

a. ㅇ. M Mubuku Valley, E. Ruwenzori, $6000 \mathrm{ft.,} \mathrm{and} \mathrm{Feb.} \mathrm{[No.} \mathrm{141.} \mathrm{R.} \mathrm{E.} \mathrm{D.]}$

Iris dark brown; bill olive-brown; feet olive.

[A few Green Snndpipers were seen on the rivers on Ruwenzori up to an altitude of $\left.10,000 \mathrm{ft} .-R . B . H^{*}\right]$

Galilinago nigripennis Bonap.

Gallinago nigripennis Reich. Vög. Afr. i. p. 236 (1900).

a. o . 80 miles W. of Entebbe, $3500 \mathrm{ft} ., 2$ nd Dec. [No. 1028. D. C.]

b. o. Basoko, Upper Congo River, $1500 \mathrm{ft}$, 16th Nov. [No. 600. R. E. D.]

Iris dark hazel; bill brown or dark brown; feet greyish-green or pale yellow.

[A few examples of this Snipe were seen near Entebbe and also on the Congo near Basoko, where one was obtained.-R. B. W.

Crex Crex (Linn.).

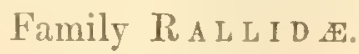

Crex crex Reich. Vög. Afr. i. p. 277 (1900).

a. ․ 12 miles W. of Entebbe, $3500 \mathrm{ft}, 24 \mathrm{th}$ Nov. [No. 2005. G. L.]

[This was the only example of the Corn-Crake met with during the Expedition.R. B. W.]

Crex egregia (Peters).

Crex egregia Reich. Vög. Afr. i. p. 278 (1900).

u. $q$ imm. Mokia, S.E. Ruwenzori, $3400 \mathrm{ft}$., 10th June. [No. 442. R. E. D.]

Iris hazel; eyelids yellowish-brown; bill and feet greyish-brown.

[Two examples of this Crake were scen on the plains to the S.E. of Ruwenzori.R. B. W.] 


\section{Family C OL U MI B I W .}

\section{Vinago Caliva (Temm.).}

Vinago calva Reich. Vüg. Afr. i. p. 39t (1901); Grant, Ibis, 1908, p. 316.

a. o. 40 miles WV. of Fort Beni, Semliki Valley, 3000 ft., 13 th Aug. [No. 3548. li. B. $W^{\prime}$.]

Iris light blue; cere and basal part of the bill pink, tip white; feet yellow.

[This Green Fruit-Pigeon was very plentiful in the Congo Forest. It was to be seen flying about in small flocks of from 10 to 15 individuals, which usually kept to the tree-tops. $-R, B . W$.

\section{HaṔlOPELIA JACKSONI Sharpe.}

Haplopelia jaclesoni Sharpe, Bull. B. O. C. xiv. p. 93 (1901) [Rumenzori].

$a, b$. q et $q$ juv. Mubuku Valley, E. Kitwenzori, $8000 \mathrm{ft}$, 20th \& 21st Jan. [Nos. 1170. D. C. ; 3125. R. B. W. ]

c. ơ. Mubuku Valley, E. Ruwenzori, $6500 \mathrm{ft.}$. 9th Feb. [No. 2150. G. L.]

d,e. of et o imm. Mubuku Valley, E. Ruwenzori, 8000-0000 ft., 13th-30th March. [Nos. 1335. D. C.; 2262. G. L.]

Iris dark reddish-brown, purple, or mauve; bill black; feet dark pink or dull red.

The type of this species is a quite immature bird, as is evidenced by the shape of the bill, which is long and thin, and by the rufous edges of the secondary-quills and of some of the wing-coverts.

The present collection contains two fully adult male examples: these differ from the type in their larger size and greyer underparts, shading into whitish on the belly, while the grey tips of the tail-feathers are much wider (1.3 inch) and much more sharply defined.

The adult fomale differs from the male. 'The upperparts are earth-brown, shading into bronzy-rufous on the upper mantle, nape, and occiput, and there is no trace of the grey, violet- or green-glossed, mantle which characterises the male; the entire underparts below the neck as well as the under tail-coverts are rich vinous.

Another specimen (No. 2262), which has been marked " $\sigma$ " by Mr. Legge, has the upperparts like those of the two adult males mentioned above, but the underparts are rich vinous like those of the female. It is difficult to account for this intermediate plumage, for the immature male type, though obviously a quite young bird, does not differ much from the adult male in the colour of the underparts, which are mostly grey suffused with vinous on the breast.

A quite young female example has the upperparts earth-brown, as in the adult female, but the quills and wing-coverts are margined with rufous and the feathers of 
the forchead are whitish, tipped with brown; the chin and throat are white; the breast narrowly barred with dark brown and rufous; and the belly and under tailcoverts rufous, shading into lighter brown on the sides and flanks.

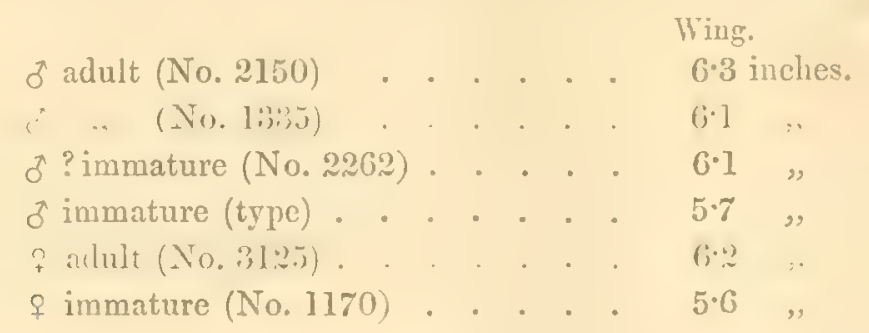

I may here remark that $H$. seimundi Sharpe, from Fernando Po, and $H$. plumbescens Sharpe, from Efulen, S. Cameroon, are the adult and young of one and the same species, the latter name having priority. An adult male example recently sent home by Mr. Bates from the River $J_{a}, S$. Cameroon, agrees perfectly with the type of H. seimundi.

[Jackson's Dove was found only on Ruwenzori; it frequented the forest and lower half of the bamboo-zone and, though not uncommon, was a difficult bird to procure. We often saw a Dove in the same region which appeared to be smaller and almost black in colour, but it was always met with among the thickest and darkest parts of the forest and for some months we failed to obtain a specimen. We nicknamed this bird the "Black Dove." Eventually Mr. Carruthers shot what we believed to be a "Black Dore," and it proved to be a young example of H.jacksoni. Whether this was really the bird we named the "Black Dove" or not is uncertain, for it was always rery shy and remarkably strong on the wing, and never conreyed the impression of being an immature bird. $-R . B . W$.]

Columbi arquatrix 'T'emm.

Columba arquatrix Reich. Tögr. Afr. i. p. 403 (1901).

«-f. o ․ Mubuku Valley, E. Ruwenzori, 9000 ft., 16th-18th Feb. [Nos. 1231, $1235,1236,1240,1241 . D . C . ; 2157 . G . L$.

g. f. Mubuku Valley, E. Rurenzori, $9000 \mathrm{ft}$., Ist MIarch. [No. 127S. D. C.]

Iris dark grey, eyelids yellow; bili and feet bright yellow.

Dr. Reichenow has described as $C$. sjöstedti an allied species from Cameroon with the head entirely grey.

[The Spotted Wood-Pigcon was fund on Ruwenzori up to $10,000 \mathrm{ft}$. In December vast flocks frequented the lower slopes of the mountains, but early in March not one was to be seen in the same locality, though higher up the mountains, at $8000-9000 \mathrm{ft}$., they were numerous from the middle of February till the middle of M[arch. 'They 
were feeding upon the berries of the Podocarpus trees, and were then quite unfit for human food; indeed, they are probably poisonous if eaten constantly, as we found to our cost. $-R . B . W$. $]$

\section{Columba unicincta Cassin.}

Columba unicincta Reich. Vög. Afr. i. p. 4.01 (1901).

a, b. o ․ Mpanga Forest, Fort Portal, $5000 \mathrm{ft}, 13$ th \& 19 th Sept. [Nos. 511. R. E. D.; 3585. R. B.W.]

'This species is new to the British Museum. 'There are examples in the Jackson Collection.

[This fine Wood-Pigeon was plentiful both in the Congo and in the Mpanga Forests, but was an extremely difficult bird to obtain, as it frequented the tops of the tall trees. Although its decp mournful cooing was constantly to be heard, it was seldom seen within shot. It was not met with in the forest-zone on Ruwenzori, although at certain times $C$. arquatrix was numerous there.-- R. B.W.]

\section{'Turtur senegalensis Linn.}

Turtur senegalensis Reich. Vög. Afr. i. p. 406 (1901) ; Graut, Ibis, 1908, p. 316 [N.W. of Lake Tanganyika].

Stigmatopelia seriegalensis Jackson, Ibis, 1906, p. 509 ['T'oro].

a. ․ 100 miles W. of Entebbe, $4100 \mathrm{ft}$, 6th Dec. [No. 1041. D. C.]

b-g. o f. Mokia, S.E. Ruwenzori, $3400 \mathrm{ft.}$, Ist--19th May. [Nos. 1468, 1469, 15 $40,1579,1587,1588$. U. C. $]$

Iris dark hazel ; bill black; feet dull red.

[The Senegal Turtle-Dove was very plentiful on the plains in the dry acacia-cuuntry around the south end of Ruwenzori, but was not seen on the mountains. It was met with near Entebbe and Fort Portal.-R. B. W.]

\section{'ívrtur damarensis Fimsch \& Hartl.}

Turtur capicola damarensis Reich. Vög. Afr. i. p. $41+$ (1901); (inant, Ibis, 1905, p. 20(13 [Mulema].

a. + vix ad. Mokia, S.E. Ruwenzori, $3400 \mathrm{ft} ., 19$ th May. [No. 1591. I). C']

Iris dark hazel; bill black; feet dull red.

[The Damaraland 'Iurtle-Dove was plentiful at the foot of the mountains around the south end of Ruwenzori, but did not appear to occur above $5000 \mathrm{ft}$. It was always a remarkably shy bird.- $R . B . W$. 
I'URtur semprorquatus (Rüpp.).

Turtur semitorquatus lieich. Vög. Afr. i. p. 409 (1901); Grant, Ibis, 1905, pp. 203, 201

[Mulema and S.W. Ankoli].

Streptopelia semitorquata Jackson, Ibis, 1906, p. 508 [Entebbe; Ruwenzori].

थ. o. 12 miles W. of Entebbe, $3500 \mathrm{ft} ., 24$ th Nov. [No. 1008. D. C.]

b. Ad. $\$ 0$ miles W. of Entebbe, $3800 \mathrm{ft}$., 3rd Dec. [No. 3025. R. B. IV.]

c $-y \cdot o^{7}$ ㅇ. Mubuku Valley, L. Ruwenzori, $6000 \mathrm{ft} .$, 1st-20th January. [Nos. 72. R.E.D.; 1085, 1088, 1109. D. C.; 3124.R.B.W.]

Iris dark hazel, with a ring of red or orange; eyelids red; biil black; feet red, dull red, or pink.

['The Half-collared 'Turtle-Dove was plentiful all round the range and ascended to the lower margin of the forest-zone, but was never seen above $7000 \mathrm{ft},-R . B . W$.]

IJMPaxistria tYMPanistria ('Temm.).

Tympanistria tympanistria Reich. Vög. Afr. i. p. 424 (1901).

a. o. 120 miles W. of Entebbe, $4200 \mathrm{ft}$, 8th Dec. [No. 1048. D. C.]

b, c. o. Mubuku Valley, E. Ruwenzori, $6000 \mathrm{ft}$., 18th \& 20 th Jan. [Nos. 1166, 117. I. C.]

d. o imm. " ",$\quad 5000 \mathrm{ft}$, 14th March. [No. 2198. G. L.]

e,f. ơ. Mokia, S.E. Ruwenzori, $3400 \mathrm{ft}$., 11th \& 23rd May. [No. 358. R. E. D.; c. 1547. D. C.]

Iris dark hazel; bill black, dark reddish-brown, or mauve ; feet dull red.

['This beautiful Dove was occasionally seen on Ruwenzori up to $7000 \mathrm{ft}$. It was rather uncommon below the mountains, but was met with throughout the journey.R. B. $W$.

Chalcopelia afra Lim.

Chalcopelia afra Reich. Vög. Afr. i. p. 426 (1901) [part.]; Erlanger, J. f. 0. 1905, p. 132, pl. vii. fig. 1; Oberholser, Pr. U.S. Nat. Mus. xxviii. p. 844 (1905); Jackson, Ibis, 1906, p. 509 [Ankoli].

a. 8. 12 miles W. of Entebbe, 3500 ft., 24th Nov. [No. 1007. D. C.]

b, c. q et o $\mathrm{imm}$. Mubuku Valley, E. Ruwenzori, $5000 \mathrm{ft}$, 23rd-28th March. Xis. $-233,2255 . G_{0}$ L.]

d-f. o ․ Mokia, S.E. Ruwenzori, $3400 \mathrm{ft} ., 10 \mathrm{th}-24$ th May. [Nos. 314. R. E. D.; 3375, 3412. R. B.W.]

g-i. o ㅇ. Mokia, S.E. Ruwenzori, 3400 ft., 15th-16th June. [Nos. 1631, 1632. D.C.;3492.R. B. II. 
Iris dark hazel, eyelids red; bill red, pink, or mauve; feet red or pink.

All these specimens appear to be typical examples of $C$. afia Lim., with the wingspot purple in freshly moulted specimens, but this colour becomes green with wear and exposure.

[The Purple-spotted Dove was met with from Entebbe to Fort Portal and all round the foot of the mountains, but was never seen above $6000 \mathrm{ft} .-R . B . W$. $]$

\section{Family 'TURNIUID E.}

T'UnNTX Nana Sundev.

Turnix nana Reich. Vög. Afr. i. p. 303 (1900).

a,b. o. Mokia, S.E. Ruwenzori, 3rd \& Sth May. [Nos. 263. R. E. D.; 2319. G. L.]

c. of " ", $\quad$ 17th June. [No. 1643. D. C.]

Iris grey or hazel; bill brown or horn-colour; feet brown or flesh-colour.

[This little Button-Quail was met with only on the dry plains around the south end of Ruwenzori.-R.B.W.]

\section{Family PHASIANIDE.}

Comunas delegorguei Deleg.

Coturnix delegorguei Reich. Vör. Afr. i. p. 507 (1901).

a. ơ . Southern Ruwenzori, $3000 \mathrm{ft}$., 23rd June. [No. 2411. G. L.]

Iris hazel; bill black; feet flesh-colour.

[Delegorgue's Quail was a rather uncommon bird and appeared to frequent those localities where the grass was very short and the soil dry.-K. B. W.]

Lixcalfactorita adansoni (Verr.).

Excalfactoria adansoni Reich. Vög. Afr. i. p. 509 (1901).

$a, b .0$. Mokia, S.F. Ruwenzori, $3400 \mathrm{ft.}, 4$ th \& 17th May. [Nos. 157:. I). C.; d. 2326 . G. L.]

c-e. o. " , " $\quad 4$ th \& 17th June. [Nos. 164\%. I\%, C; $3 \pm \frac{1}{3} 1,3452 . R . B . H$.

Iris red, dark red, or pink; bill black; feet yellow.

[A few exmples of Adanson's Painted Quail were seen on the plains romm the south end of Ruwenzori- $-R . B . W$. 
Francolinus schuetti Cabanis.

Francolinus schuetti Reich. Vügr. Afr. i. p. 468 (1901).

$a-c . \delta$. MIubuku Valley, E. Ruwenzori, $6500 \mathrm{ft} ., 22 \mathrm{nd} \& 25 \mathrm{th}$ Feb. [Nos. 1257, 1271.D.C.;3173.R. B. W.]

d. ơ. Mubuku Valley, E. Ruwenzori, $6500 \mathrm{ft}$, 3rd March. [No. 12S2. D. C.]

Iris dark brown; bill and feet bright red.

[Schuett's Francolin was not uncommon in the 'Toro district above $4000 \mathrm{ft}$., and was occasionally seen on the east side of Ruwenzori up to $6500 \mathrm{ft}$. It was not found at the south end of the range, its place being taken by Pternistes cranchi.- $R . B . W$.

HRANCOLINUS ICTERORHYNCIUS Heugl.

Francolinus icterorlynnchus lieich. Vög. Afr. i. p. 476 (1901).

a. o. N. Ruwenzori, $2000 \mathrm{ft}$., 20th Aug. [No. 355?. R. B. W.]

Iris dark brown; bill and feet yellow.

[A few examples of this Francolin were seen near the north end of Ruwenzori between the Semliki River and Irumu. They might sometimes be seeu perched on the lower branch of a tree. $-R . B . W$.

Grancolinus arulame Grant.

Francolinus mulemce Grant, Ibis, 1905, p. 212 [Mulema, S. Uganda].

a. ㅇ. 20 miles W. of Entebbe, $3500 \mathrm{ft}, 24 \mathrm{th}$ Nov. [No. 8. R. E. D.]

Iris dark brown; bill dark horn-colour ; feet olive-yellow.

This Francolin was first procured by the late Mr. Doggett at Mulema, S. Uganda, and in S.W. Ankoli.

Pternistes crancin (Leach). (Plate XIX. fig. 8, egg.)

Pternistes cranchi Reich. Vög. Afr. i. p. 457 (1901).

a-c. ơ. Mokia, S.E. Ruwenzori, $3400 \mathrm{ft} ., 29$ th April. [Nos. 1453, 1454. D. C.; 2300 . G. L.]

d, e. ot et imm. Mokia, S.E. Ruwenzori, $3400 \mathrm{ft}$, 2Sth May. [Nos. 1561. D. C. ; 3424. R. B.W.]

$f-h$. ot et vix ad. Mokia, S.F. Ruwenzori, $3400 \mathrm{ft}$, 13th-19th June. [Nos. $1626,1634,1651$. D. C.]

Iris dark brown; bare skin round the eye and on the throat red; bill and feet red.

Six eggs of this species are of a blunt oval shape and somewhat glossy. They are uniform pale lilac-buff, rather finely pitted and mottled all over with white. 'They: measure from 1.52 to 1.55 inch in length and 1.8 in width. 
[Cranch's Bare-throated Francolin was numerous on the plains among the acaciacountry around the south end of Ruwenzori. It was seldom seen during the heat of the day, but towards sunset its hoarse call resounded on all sides and the old cocks were often to be seen perched on the top of an ant-heap. $P$. cranchi was met with in the 'l'oro district up to $4000 \mathrm{ft}$., its place being takeu above that altitude by Fruncolinu.s schuetti. A nest of this species was found at the edge of a native path; the eggs, six in number, were placed in a slight hollow lined with a little grass and feathers, under the shelter of a large tuft of grass. $-R . B . W$.

Numida Ptilorhyncha Licht.

Numida ptilorhyncha Reich. Vög. Afr. i. p. 445 (1901).

Numida ptilorhyncha toruensis Neumann, J. f. O. 1904, p. 410 ['Toro].

a. o. 70 miles W. of Entebbe, $3700 \mathrm{ft} ., 29$ th Nov. [No. 18. R. E. D.]

b. of. Mokia, S.E. Ruwenzori, $3400 \mathrm{ft.}$, 28th May. [No. 3423. R. B. IY]

c. $\delta . \quad, \quad, \quad$ " $\quad$ th June. [No. 386.R. E. D.]

Iris dark brown; bill horn-colour or brown, base of the upper mandible reddish; wattles and bare skin blue; feet dark brown or dark grey.

[The Abysinian Helmeted Guinea-fowl was not found on Ruwenzori, but was numerous below the mountains in the more open country, especially at the south end of the range.- $-R . B . W$.

Guttera cristata (Pall.).

Guttera cristata Reich. Vög. Afr. i. p. 450 (1901); Grant, Bull. B. O. C. xxiii. pp. 14, 31 (1908).

(Guttera cristata granti Reich. t. c. p. 451.

Guttera cristata seth-smithi Neumann, Bull. B. O.C. xxiii. pp. 13, 31 (1908) [Unyoro].

Guttera cristata suahelica Neumann, 1. c. pp. 14, 31 [Lindi, German E. Africa].

«. ․ 20 miles N.W. of Fort Beni, Semliki Valley, 3000 ft., 11 th Aur. [No. 2447. G. T. ]

Iris dark brown; bill horn-colour; bare skin on the head blue, and on the throat and fore-neck red; feet black.

[A large flnck of these Crested Guinea-fowl was met with in the Eturi Forest ne'n Fort Beni.- $R . B . W$. 


\begin{abstract}
A P P E NDIX.
On some Points in the Anatomy of Bradypterus cinnamomens. By W. P. Pycraft, F.Z.S., M.B.O.U., d:c.
\end{abstract}

\title{
I. INTtodlctory.
}

'THe following short notes on the pterylosis and certain muscles of the wing and leg in Bradypterus cinnamomens were made on a single specimen, preserved in spirits, taken on Western Ruwenzori at an altitude of 7000 feet. This specimen is now in the British Museum (Natural History) (vide anteà, p. 355).

\section{Pterylography.}

Since the pterylosis of this bird presents no very striking peculiarities, it will not be necessary to describe each tract minutely; only those features, in short, which seem to be peculiar to this genus, and possibly some allied forms, will be described in cletail.

Pteryla capitis (text-fig. $14 a, p t . c a p$.$) .- This tract is rers thickly feathered, the$ continuation of the apterion colli lateralis, which in Phylloscopus, for example, extends forwards to embrace the whole side of the head as far as the eye-save for a circle of feathers surrounding the aperture of the ear,-is here only traceable with difficulty, and is interspersed with tiny semiplumes, as also is the apterion colli laterale throughout its length.

Pt. spinalis (text-fig. $14 a, p t . s p$.$) . - The most striking feature of this tract is the$ broad fan-shaped saddle which is formed over the middle of the back, terminating. immediately orer the pre-acetabular ilium.

I't. caudalis (text-fig. $14 \alpha, p t . c$.$) .-'There are 10$ rectrices, which hare rather stiff shafts and loose, almost discontinuous vanes.

Pt. colli ventralis (text-fig. $14 b, p t . c o l . v$.). - This tract, from the middle of the neck forwards to its junction with the $p t$. capitis at the throat, is reduced to a double row of small weak feathers. Rather below the middle of the neck it bifurcates, forming two broad well-defined bands, which, passing backwards, merge with the pt. ventratis.

It. ventsalis (text-fig. $14 b, p t . v e n t$.). - This tract is rather broad; at the level of the knee, however, it suddenly narrows and is continued backwards on either side of the abdomen, finally converging to meet in front of the cloacal aperture.

Pt. femoralis (text-fig. $14 a, p t$. fem.).-Though narrow, this tract is sharply defined and extends in a transverse direction from the middle of the thigh backwards to the base of the rectrices. 
Pt. cruralis (text-fig. $14 b, p t . c r$.$) . - This is not a very sharply defined tract, and the$ feathers become semi-plumous towards the knee.

Pt. humeralis (text-fig. $14 a, p t . h$.).-Sharply defined and narrow, this tract offers no peculiarities worthy of special comment.

Pt. alaris:-

Metacarpo-digital remiges or primaries (text-fig. 15, p. 456). - The tenth, counting from the wrist outwards, relatively long, extending as far as the distal $\frac{1}{3}$ of the 9th remex; the covert of this remex is very short. The 5 th to 7 th remiges subequal, and
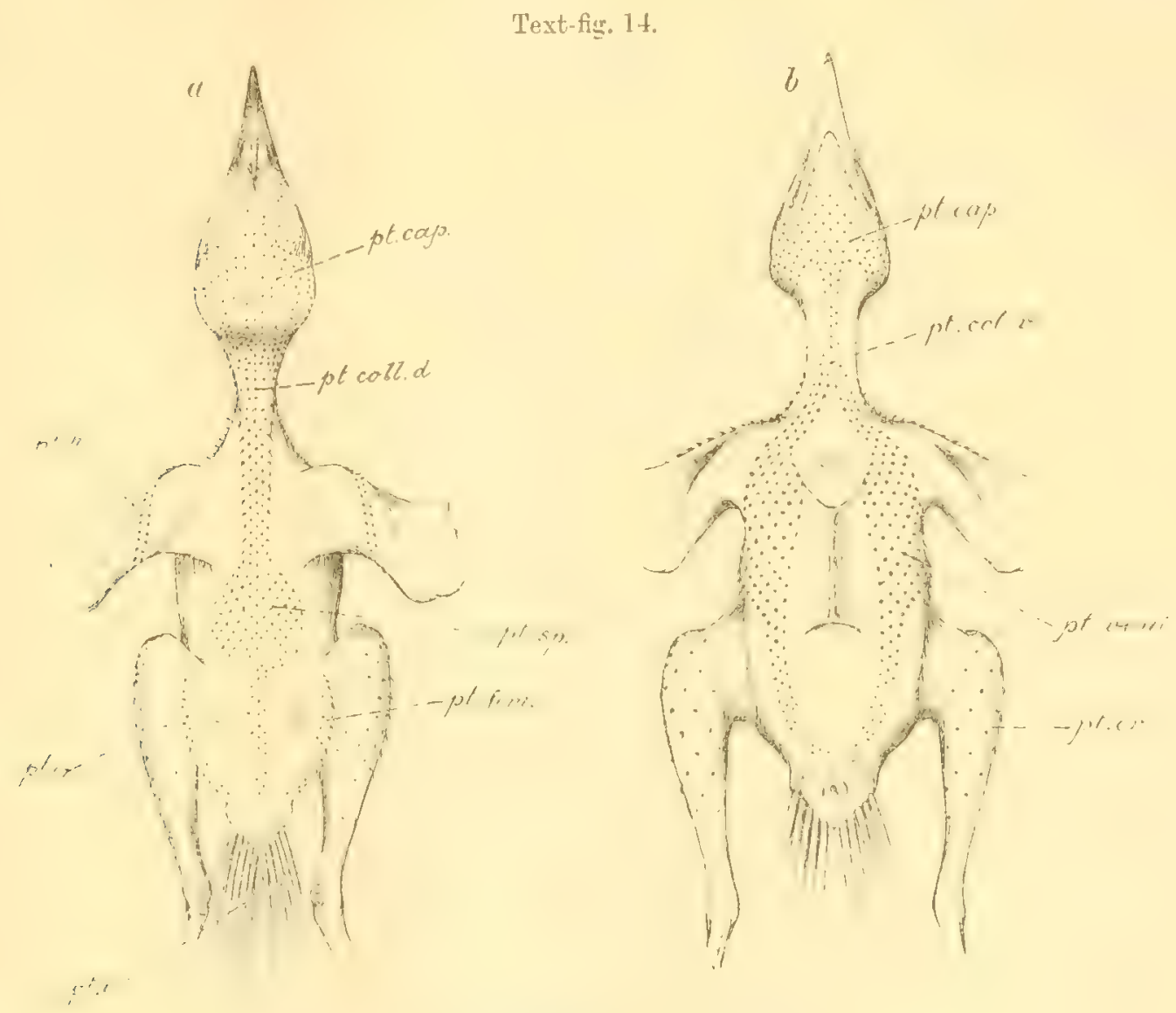

Pterylosis of Bradyptemes cimnomomens.

$a$, dorsal aspect; $b$, ventral aspect.

longest in the wing. The extreme shortness of the outer primaries is a noticeable point. Secondaries 9, but the 9 th much reduced.

The coverts offer no points calling for comment.

The Podotheca.-The acropodium is covered by 3 large and 3 small distal scutes; the planta by a single plate.

The Claws are moderately large and strong. 
The Whamphotheca.-'There is the faintest perceptible trace of a notch at the tip of the bcak, and the nostrils are somewhat pear-shaped in outline, tapering forwards. They are protected by a membranous operculum having a thickened free edge, and the aperture posteriorly exposes a portion of a turbinal scroll.

Rictal bristles are barely traccable; the aperture of the ear is large and opens upwards and forwards.

\section{Pterylosis of Bradypterus compared with allied Forms.}

Unfortunately it has been found impossible to institute a series of comparisons between the pterylosis of Bradypterus and any considerable number of allied forms. An attempt has been made, however, towards this much desired end by contrasting Bradypterus with one or two genera which are at any rate distantly allied.

Text-fig. 15.

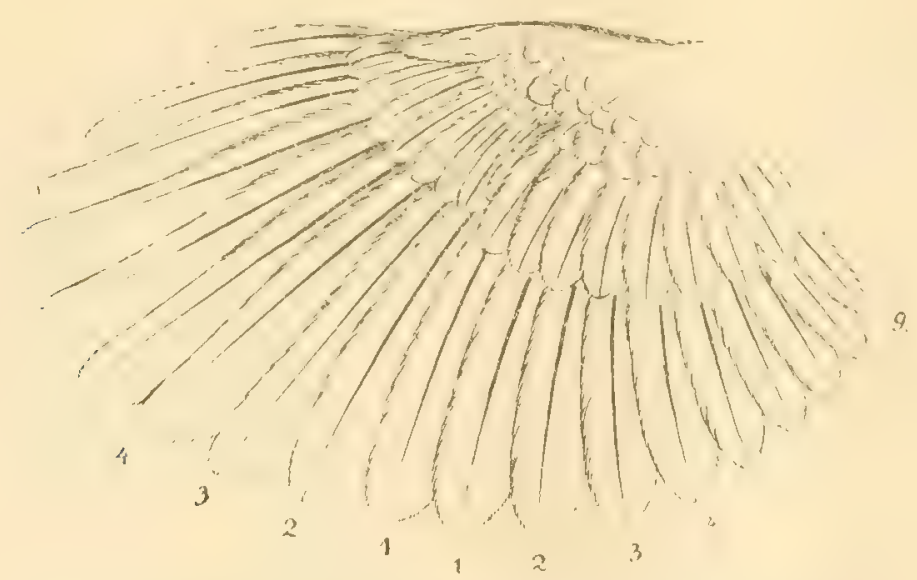

The extended wing of Bradypterus, showing its rounded character.

Bradyptev"us differs from Sylvia and Phylloscopus in the shape of the dorsal expansion of the pt. spinalis, which is fau-shaped and of considerable width, and this constitutes in striking difference, since in the genera just referred to this region of the tract takes the form of a long oval. Bradypterus differs even more from Acrocephalus, for in the latter this expansion is of a $\lambda$-shape, the stem and arms being very broad; they join two similar but very slender arms, which rapidly converge and form a narrow stem, continued backwards to the uropygium. 'Thus a small more or less diamond-shaped apterium is formed immediately over the pre-acetabular region of the ilium.

Acrocephalus, Sylvia, and Phylloscopus all agree, however, in having rictal bristles, and these are barely traceable in Bradypterus. Bradypterus, again, is peculiar among these genera on account of the great length of the 10th primary.

Acrocephalus, on the other hand, is peculiar in the specialized character of its feet, since the toes and claws are conspicuously long, while the plantar surface of the toes 
shows a decided adaptation to the bird's mode of life-clinging to reeds; and this because the proximal portion of the toes, and especially of the hallux, is markedly expanded and closely granulated, so as to afford a hold of smooth-stemmed rushes. There is no approach to this in the font of Bradypterus.

\section{MYOLOGT.}

The condition of the deltoideus major and gastrocnemius muscles only need be lescribed for the purposes of this paper.

Wing-Muscles.

The deltoideus major in Bradypterus is in a condition rather more primitive than that of the Whitethroat and Chiffchaff, but is slightly more specialized than in Acrocephalus; while in all these genera this muscle has preserved more of its primitive character than is usual among the Passeres.

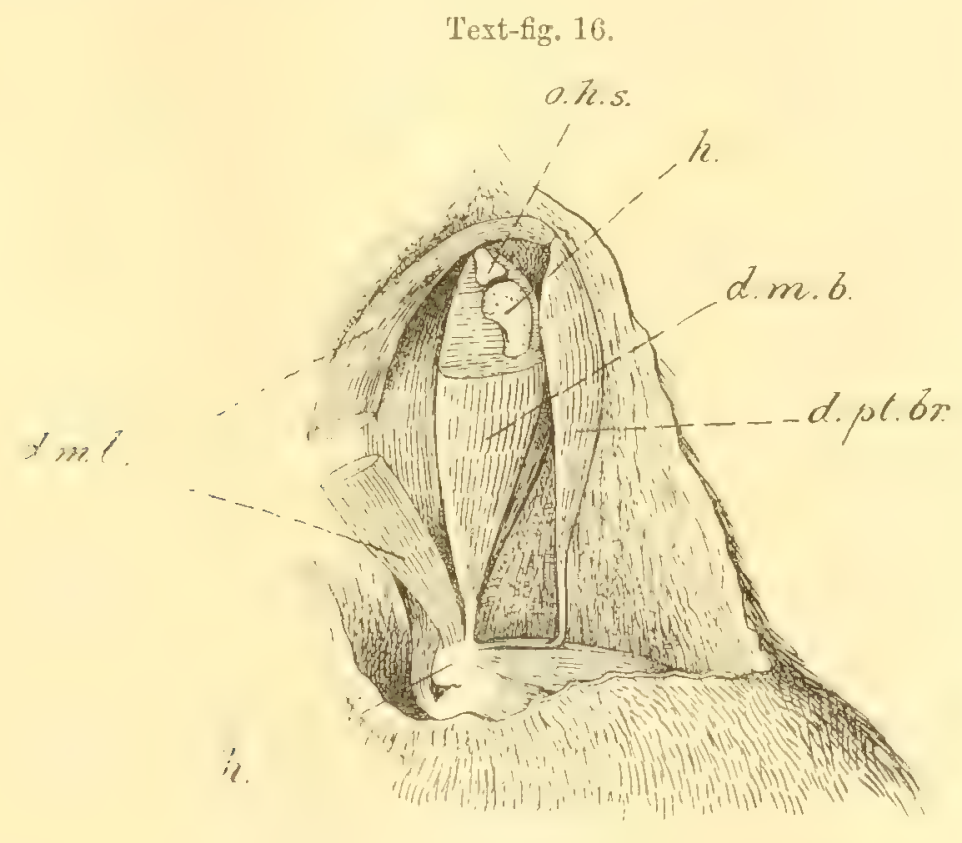

Wing-muscles of Braclypterns, slightly diagrammatic.

'The longus division (text-fig. 16, d.m.l.) is divisible into two layers. The outer rises from the inner aspect of the expanded free end of the furcula; while the inner and immediately underlying moiety, which is nearly as large as the outer, arises from the acrocoracoid. These two divisions, obviously derived from a two-headed condition of a single muscle, fuse midway down the arm to be inserted in the form of a thick Heshy stump on to the ectepicondylar process of the humerus, but distinct from the delt. maj. brevis.

VOL. XIX.-PART IV. No. 60.-March, 1910. 
The brevis portion is of large size, extending the whole length of the humeral shaft. With regard to its origin it may be noticed that, in addition to the usual attachment to the os humero-scapulare (text-fig. $16,0 . h . s$. ), it has also a ligamentous slip from the neck of the scapula.

In Acrocephalus the longus division has similarly two points of origin, and fusion between the two moieties does not take place till midway down the arm. The muscular belly thus formed is continued downwards to be inserted in common with the tendon of the brevis division. This tendon looks, indeed, as if it really belonged to the $d . m$. brevis, and as if the longus division had grafted itself on to the brevis portion just before this passes into tendon.

\section{Leg-Muscles.}

Of the leg-muscles of Bradypterus only the gastrocnemius is of sufficient interest to demand notice here.

The external head is very thick, fleshy, and spindle-shaped; the belly terminates in a point rather below the middle of the tibial shaft, where it gives place to a long tendon joined almost at once by the tendons of the middle and tibial heads. The belly, at about its middle, and just below the biceps loop, sends off a thin sheet of muscular fibres to the middle head.

The tibial, like the external head, is very strongly developerl, and ends in a point running parallel with, and anchored to, the tendon proper to this head by a thin sheet of tendinous tissue. The tendon, it will thus be seen, is rather peculiar, for, instead of forming a continuation of the extremity of the fleshy portion of the muscle, it is given off from the post-axial border of the belly-that is to say, the tendinous portion of the muscle becomes concentrated rather high up, and not at the end of the muscle as is usual.

The middle head is short and thick, and sharply truncated distally, giving place very suddenly to a tendinous sheet which runs parallel to, and is fused with, the tendon of the tibial head just described. Lower down the leg, however, this tendinous sheet develops a fairly well-marked and typical tendon along its middle, and this eventually joins the tendons of the external and middle heads. But this head shows a decided tendency to fuse with the tibial head, and this condition is actually reached in the Whitethroat, where it passes into the tibial head near the middle of that division. In Acrocephalus the middle head is extremely feeble, taking the form of a thin sheet of muscle terminating abruptly as in Bradypterus, and attached, as it were, to a delicate tendinous sheet stretched between the terminal halves of the fleshy bellies of the external and internal heads. Not until this sheet has nearly approached the anklejoint is the characteristic tendon developed.

Not the least interesting fact about the gastrocnemius of Bradypterus is the fact that the fused tendons of the external and tibial heads are ossified. 'This ossificatior. 
extends downwards to about the level of the distal $\frac{1}{6}$ of the tibial shaft, and upwards along each tendon as far as the fleshy portion of its respective muscle.

My attention was drawn to this fact by Mr. Woosnam, who, in skinning specimens of this bird, found these tendons difficult to sever.

\section{Summary.}

Owing to the fact that I had but a single specimen of Bradypterus for dissection, which it was desirable to keep as complete as possible, and but little material for the purposes of comparison, it is not possible to say anything definite as to the probable systematic position of this genus. It is certainly distinctly separable from the genera with which it has been compared. My colleague Mr. Ogilvie-Grant is inclined to think it may stand somewhere near Cetti's Warbler, and I hope shortly to have specimens of that bird for dissection in order that this point may be tested.

The relatively shallow keel on the breast-bone and the great development of the gastrocnemius muscle show that it is not much addicted to flight, and the peculiar, almost discontinuous character of the tail-feathers may be taken as further evidence on this head. 

PLATE X. 
PLATE $\mathbf{X}$.

Hig. 1. Malimbus faydani Grant, ơ, p. 270.

2. Spermospiza poliogenys Grant, ㅇ, p. 283.

3. Pyromelana crassirostris Grant, o, p. 287.

4. Neisna nyansa Neumann, ơ, p. 302. 


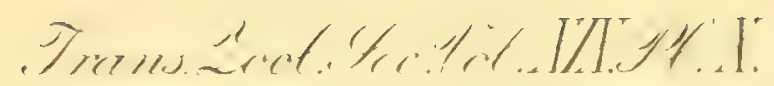

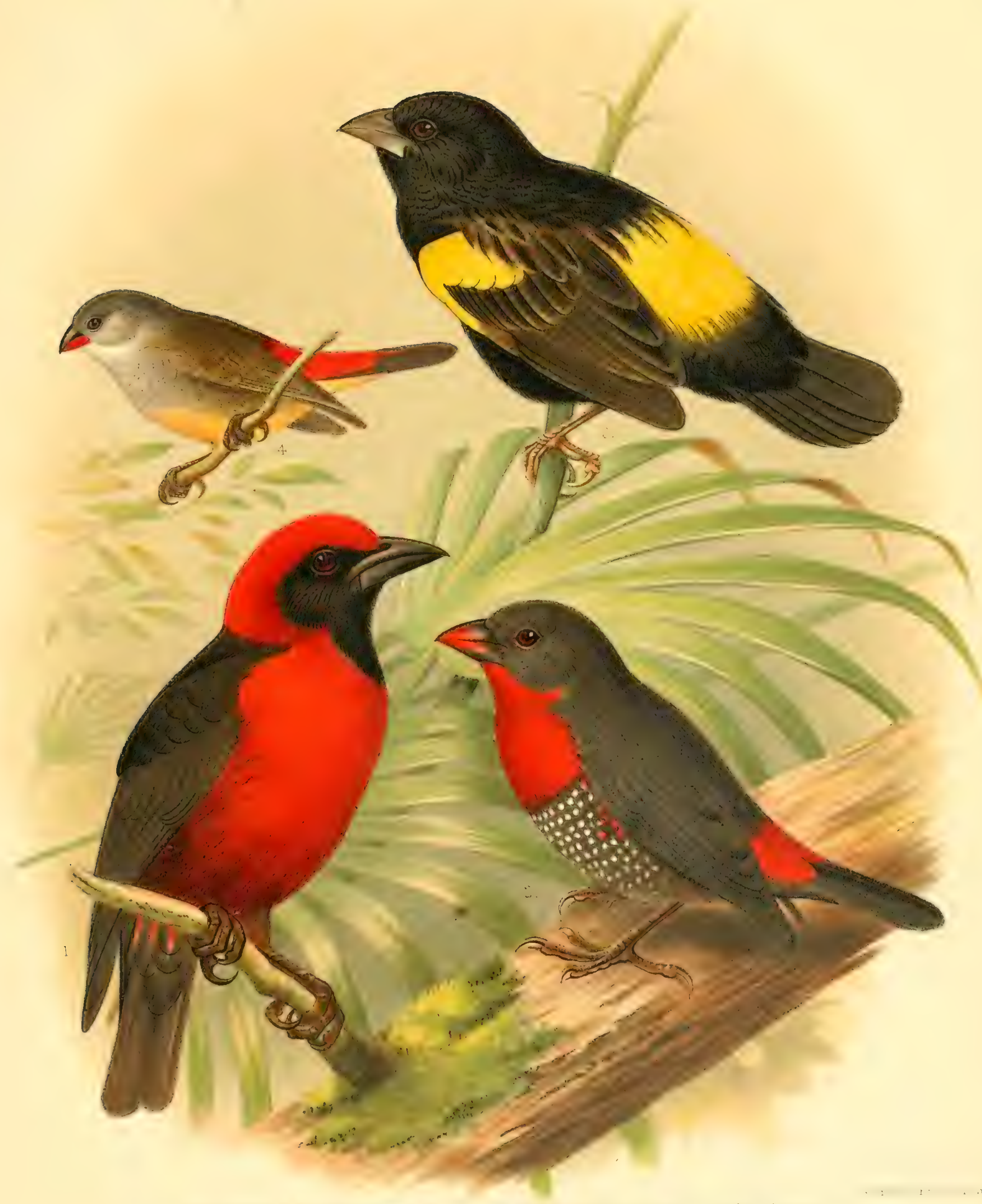



I'LATE YI. 


\section{PLA'IE XI.}

Kigs. 1 \& 2. Nesocharis ansorgei Irartert, \& 9 , p. 295.

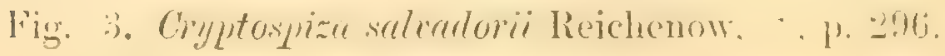

4. Pytelia belli Grant, o, p. 291. 


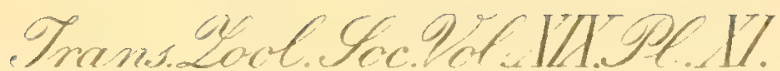

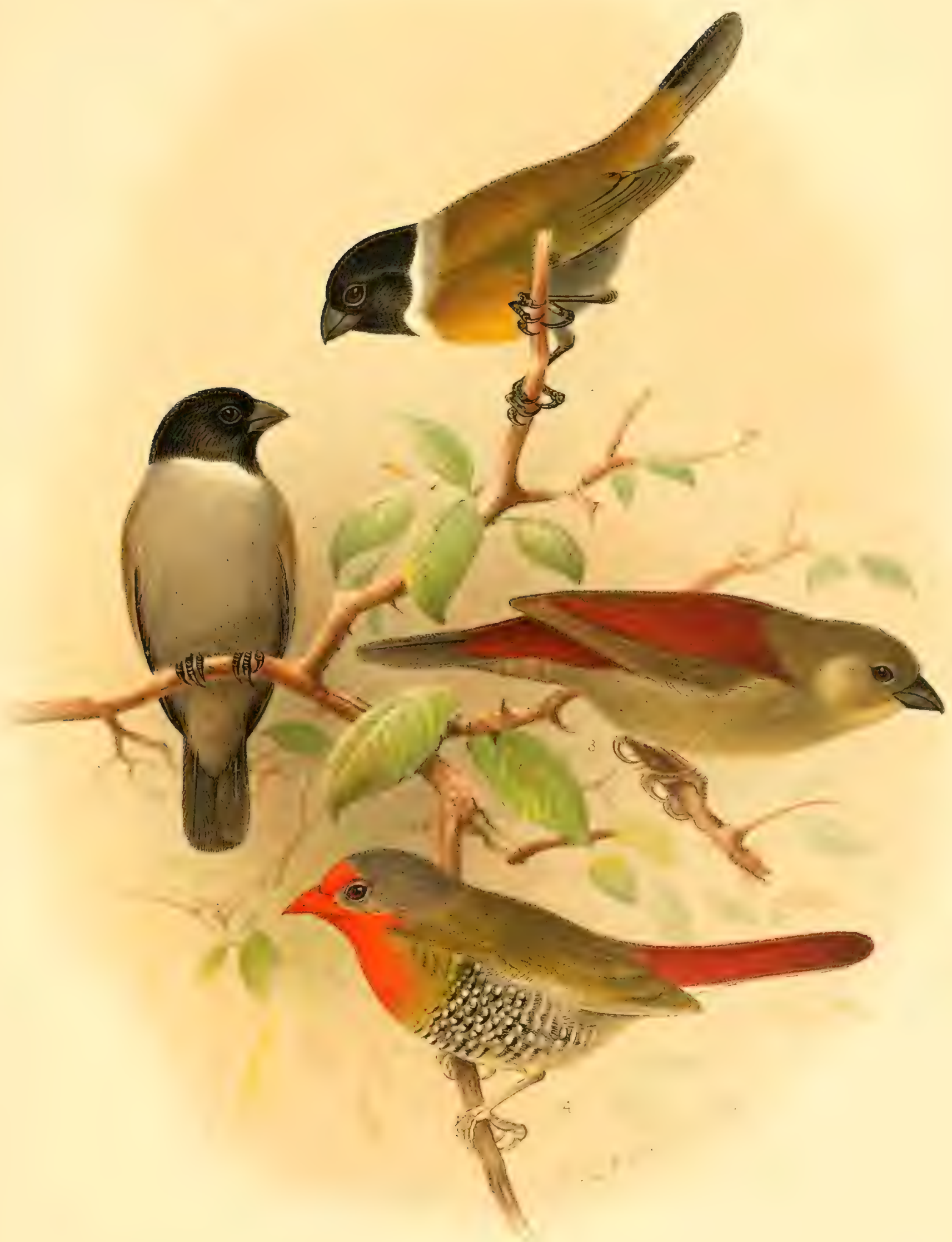



PLATE XII.

VOL. XIX.-PART IV. NO.61.-MLereh, 1910. 
PLATE XII.

Higs. I \& 2. Nectarinia dartmoutli Grant, o $q$, p. 318.

Fig. 3. Cryptolopha alpina Grant, ơ, p. 407. 


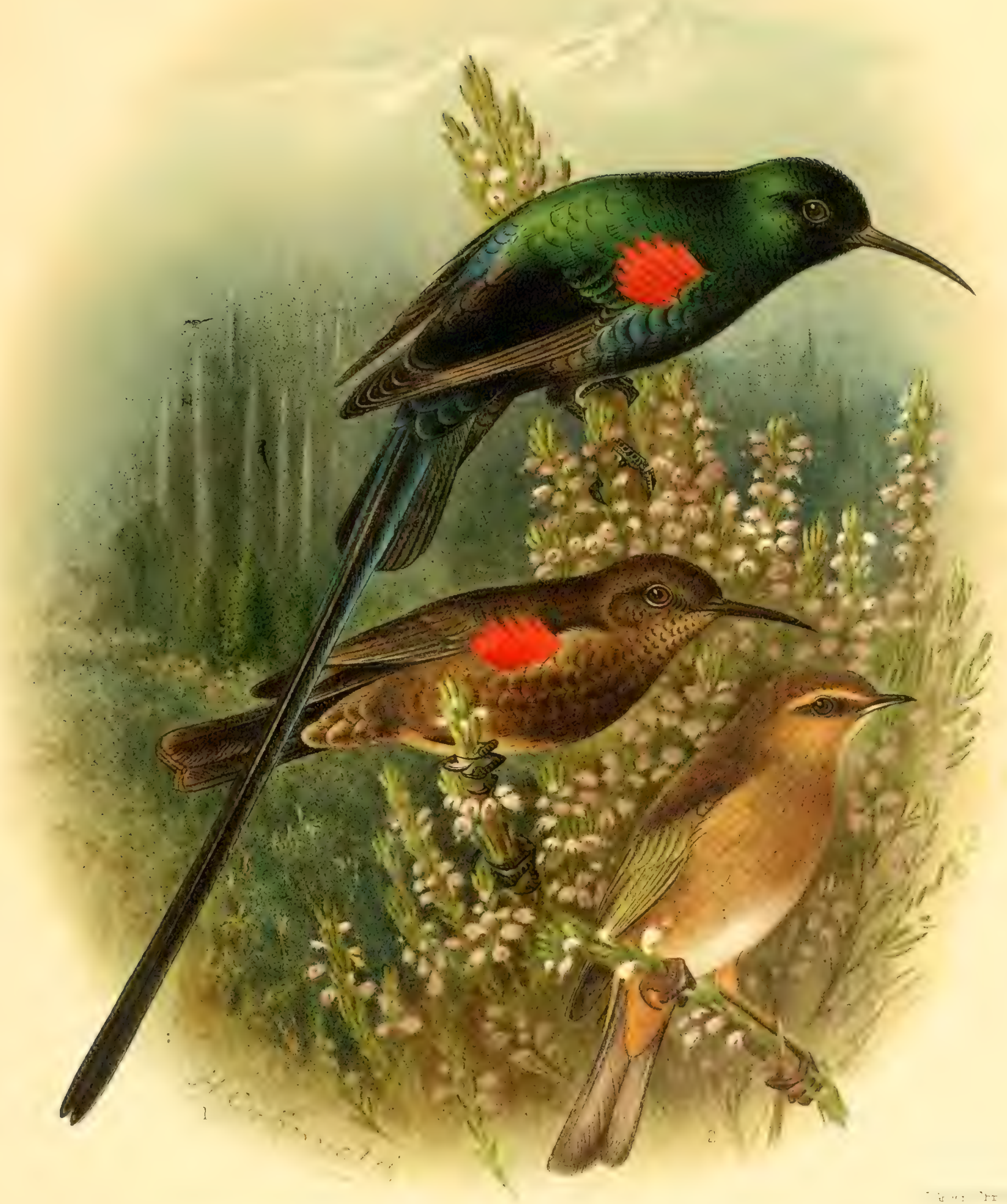



PLATE XIII. 


\section{PLA'IE XIII.}

Fig. 1. Pholidornis denti Grant, ơ, p. 332.

2. Anthoscopus roccatii Salvadori, ot, p. 335.

3. Sylviella denti Grant, ơ, p. 364.

4. Anthus leggei Grant, o*, p. 314. 


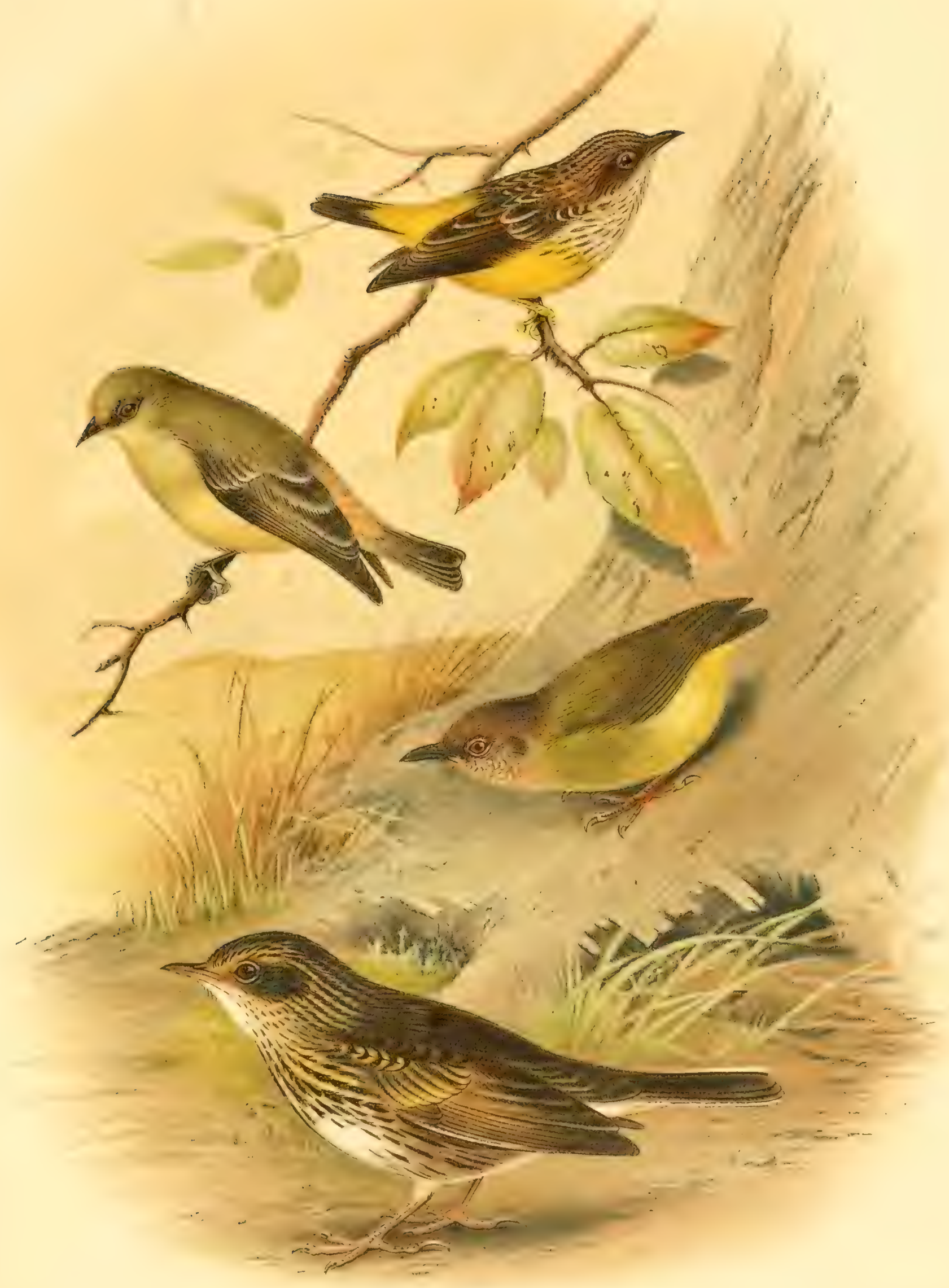



PLATE XIV. 
PLATE XIV.

Fig. 1. Erythrocercus congicus Grant, s, p. 403.

-. Apalis affinis Grant, o*, p. 358.

3. ., denti Grant, 오, p. 355.

4. ", muenzorii Jackson, ơ, p. 360 


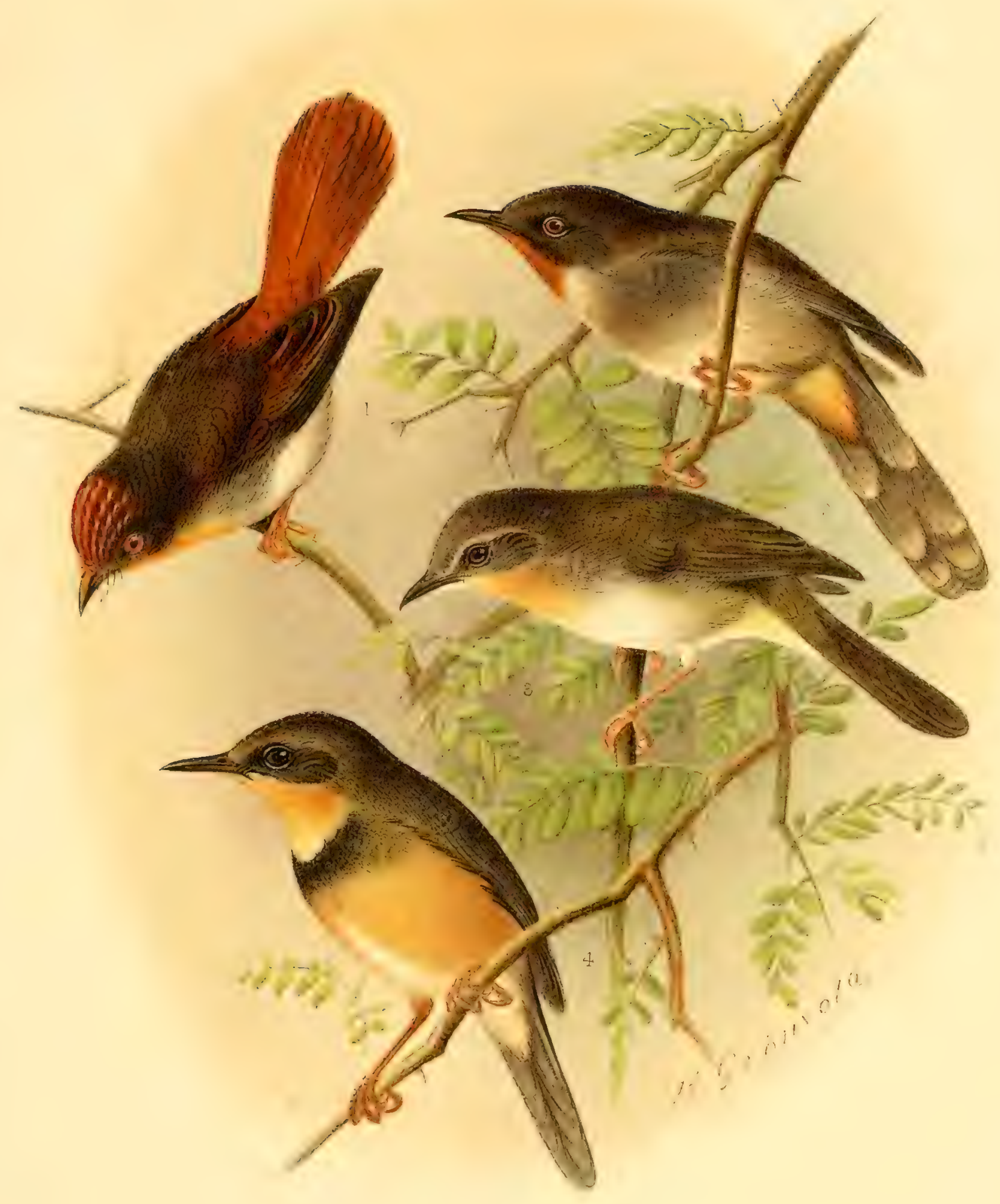



PLATE XV 


\section{PLATE XV.}

$\left.\begin{array}{l}\text { Fig. 1. Alethe woosnami Grant, o } \\ \text { 2. " carruthersi Grant, o }\end{array}\right\}$ p. 37t. 


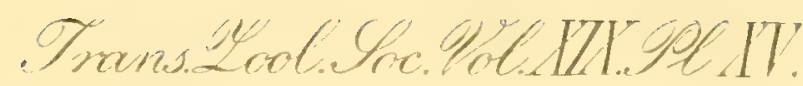

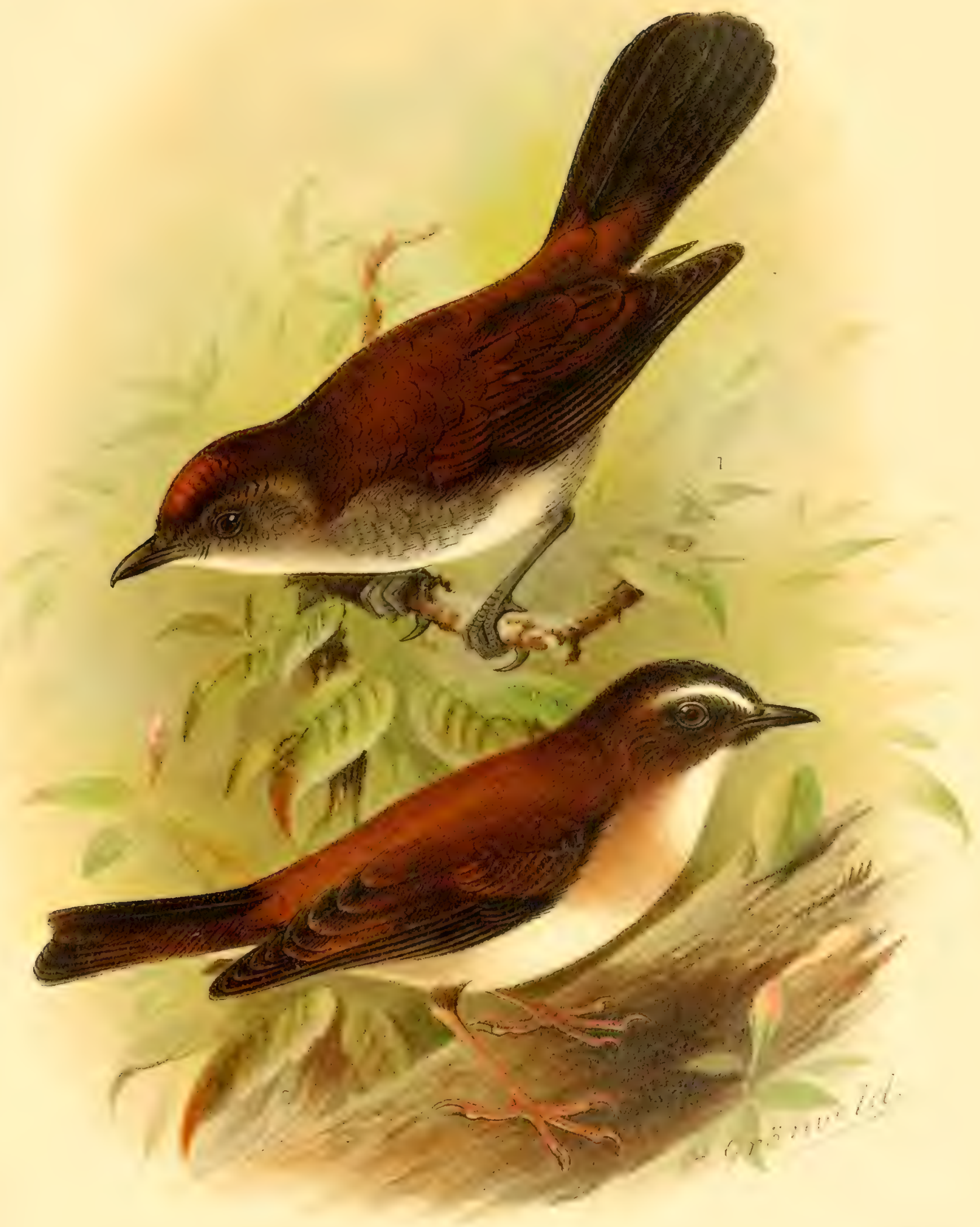



PlAPE XVI.

rot. XIX.-PART iv. No, $02 .-$ Weroh, 1910. 
W. K. OGILVIE-GRANT-AVES.

\section{PLATE XVI}

Fig. 1. Bradypterus alfiedi Hartlaub, ㅇ, p. 356.

2. Cossypha archeri Sharpe, o, p. 370.

3. Bradypterus barake Sharpe, ot, p. 355. 


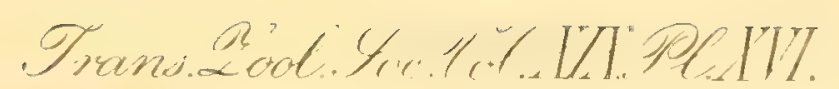

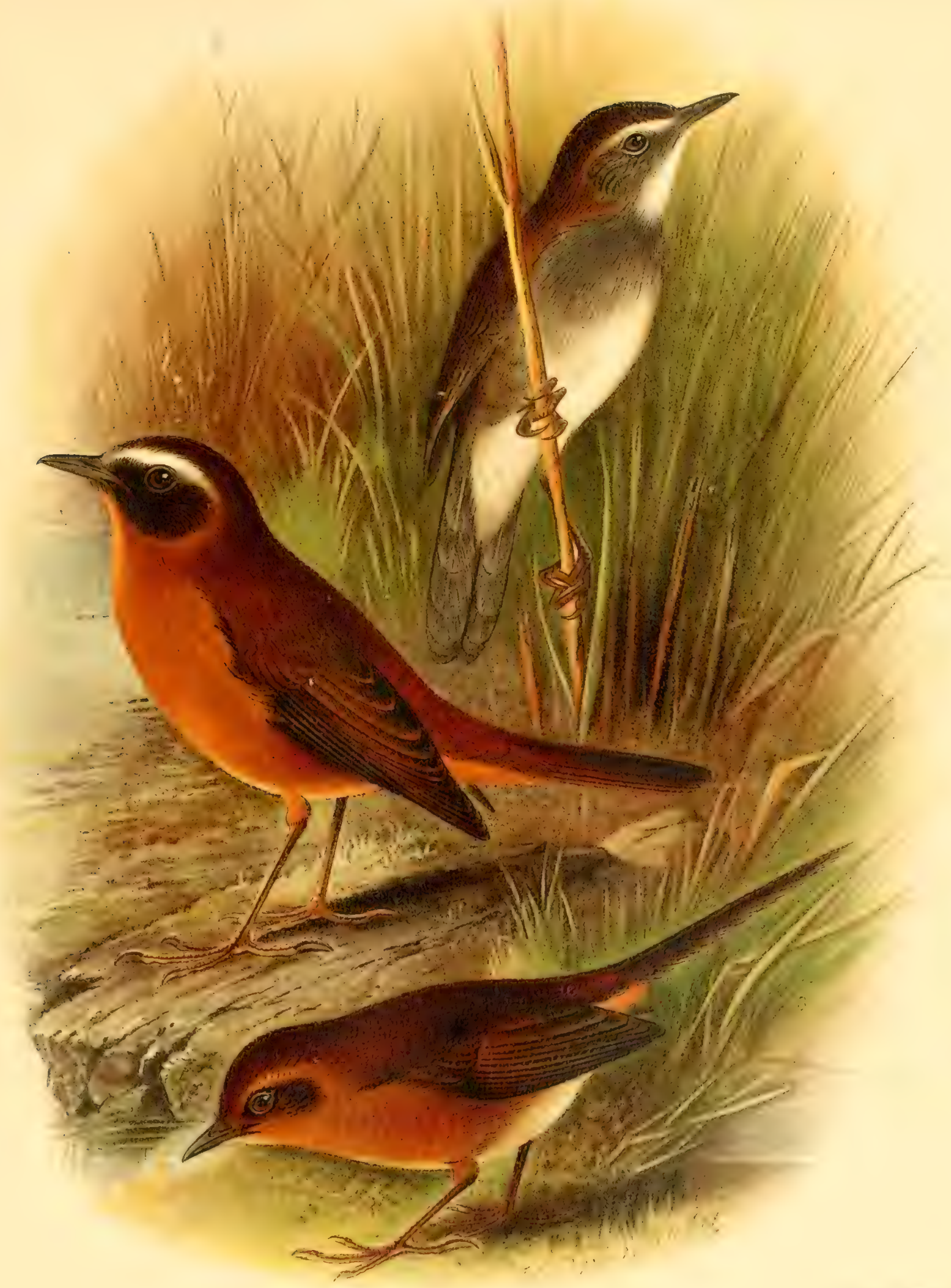



PLATE XVII.

$3 x^{2}$ 


\section{PLA'IE XVII.}

Hig. 1. Phyllanthus czamikowi Grant, o, , 1. 378.

2. Bleda wonsnami Grant, ơ, p. 384 . 


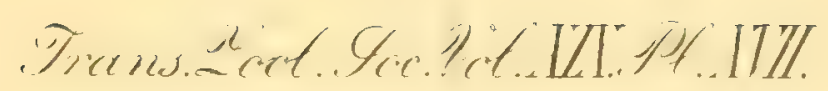

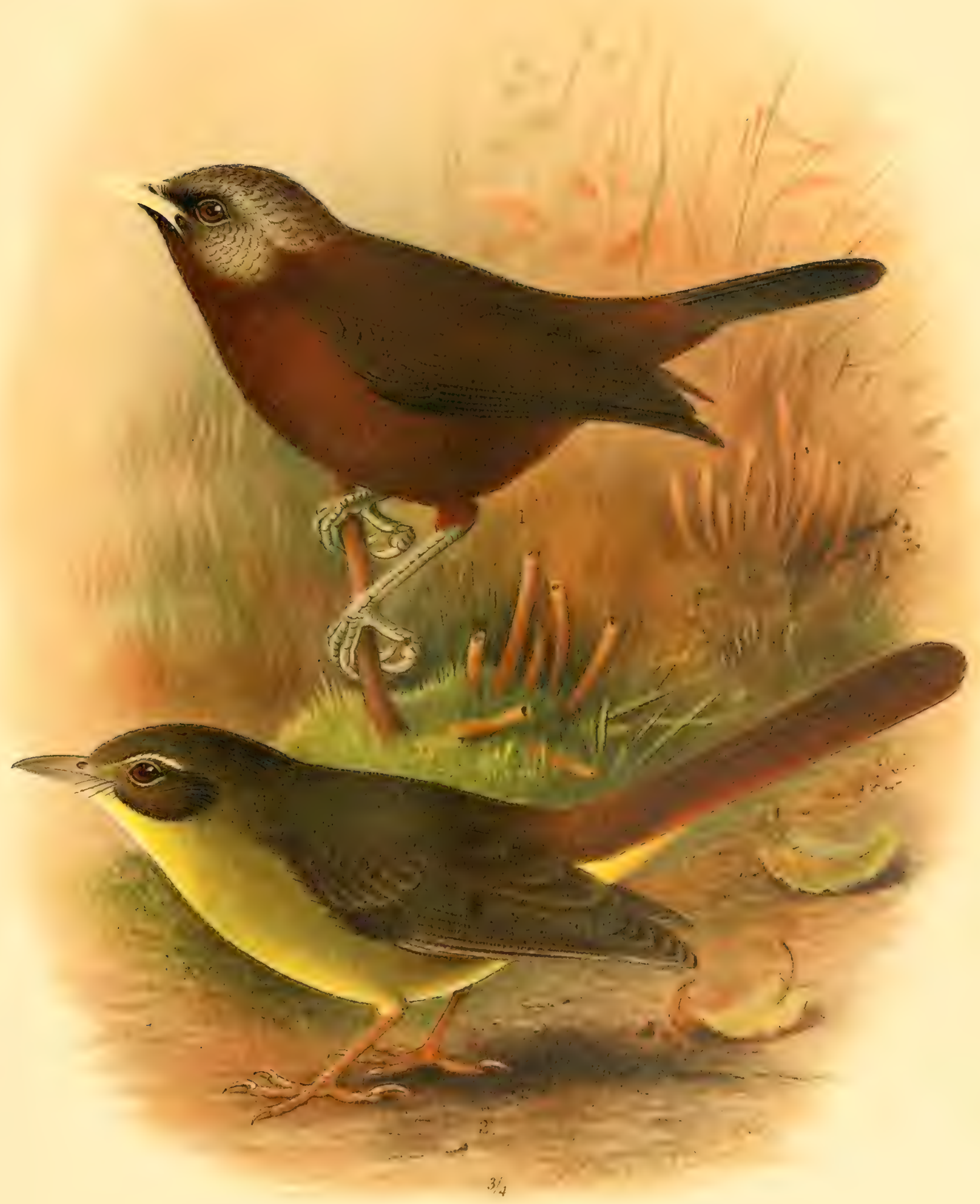

I.Green.Chromo lith 

PLATE XVIII. 


\section{PI.A'TE XVIII.}

l'ig. 1. Trochocercus bedfordi Grant, c , p. 403.

2. Batis diops Jackson, ơ, p. 398.

3. Chloropeta gracilirostris Grant, o , p. 397.

4. Tarsiger mwenzori Grant, ơ , p. 394. 


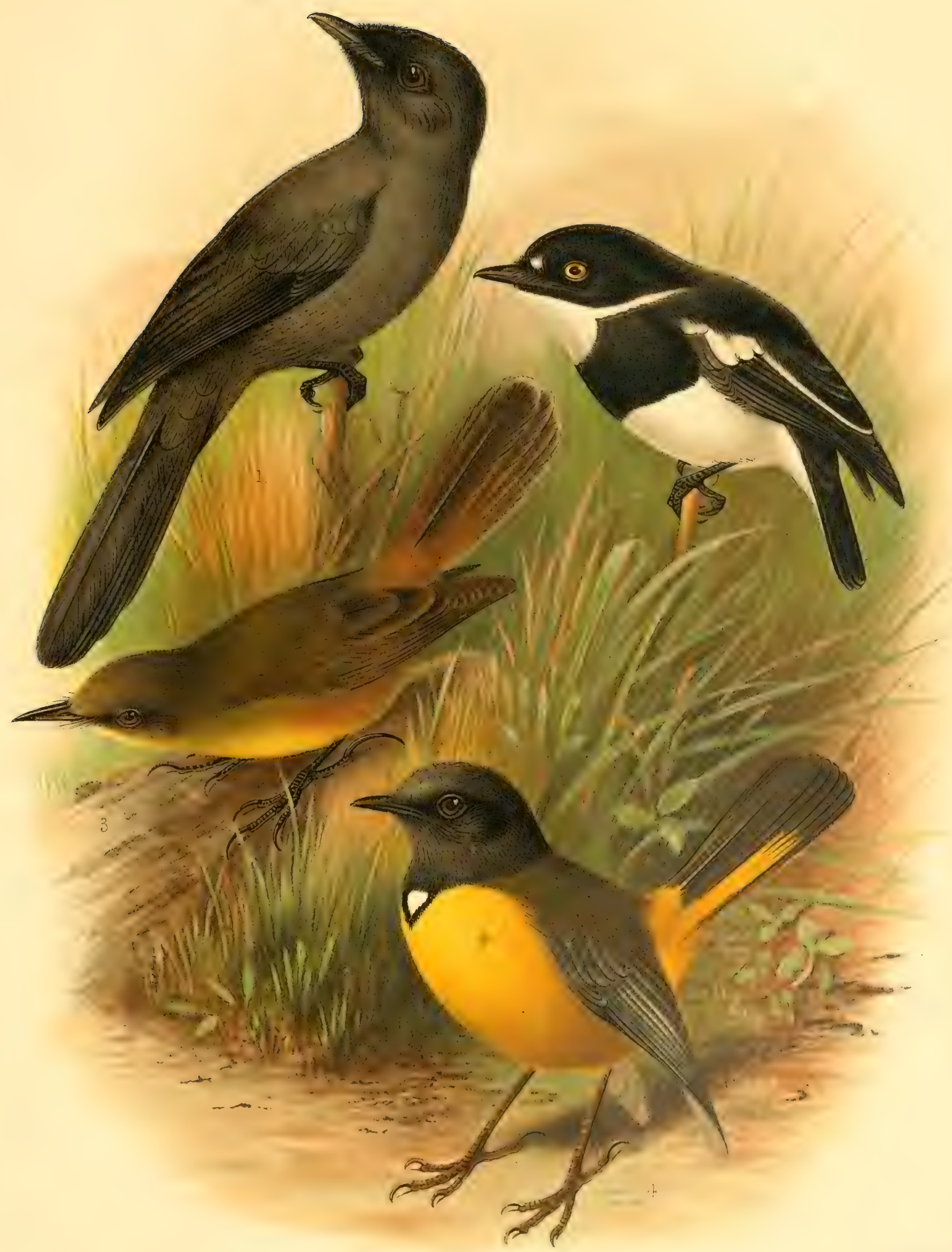

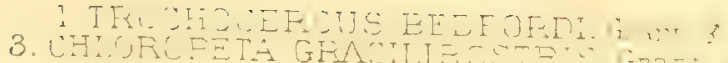



PLATE XIX. 


\section{PLATF XIX. (FGGS.)}

Min. 1. Fmberizn Anviventris, p. 309.

-. Hyphantornis jacksoni, p. 276.

$\therefore$ Gencichla piagqae, p. 368.

4. Hyphantornis jacksoni, p. 276.

5. Emberiza flaviventris, p. 309 .

i. Sylviella barakn, p. 362 .

¡. Cinnyris cupreus, p. 325.

$\therefore$ Pternistes cranchi, p. 452.

7. Nectarinia kilimensis, p. 317.

11. Camaroptera griseoviridis, p. 364.

1i. Cisticola erythrops, p. 3448.

12. Cryptolopha alpina, p. 407.
Fig. 13. Terpsiphone suatielica, p. 404.

14. Cisticola chubbi, p. 351.

15. Amblyospiza melanonota

16. p. 282

17. Edicnemus vermiculatus, p. 444.

18. Sit.ngra aliena, p. 279.

19. Tarsiger ruwenzori, p. 394.

20. Xenocichla kilkuyuensis, p. 382.

21. Telephonus erythropterus, p. 33 T.

22. Laninrius erythrogaster, p. 340.

23. Telephonus erythropterus, p. 337.

24. Cuprimulgus fossei, p. 4:8. 

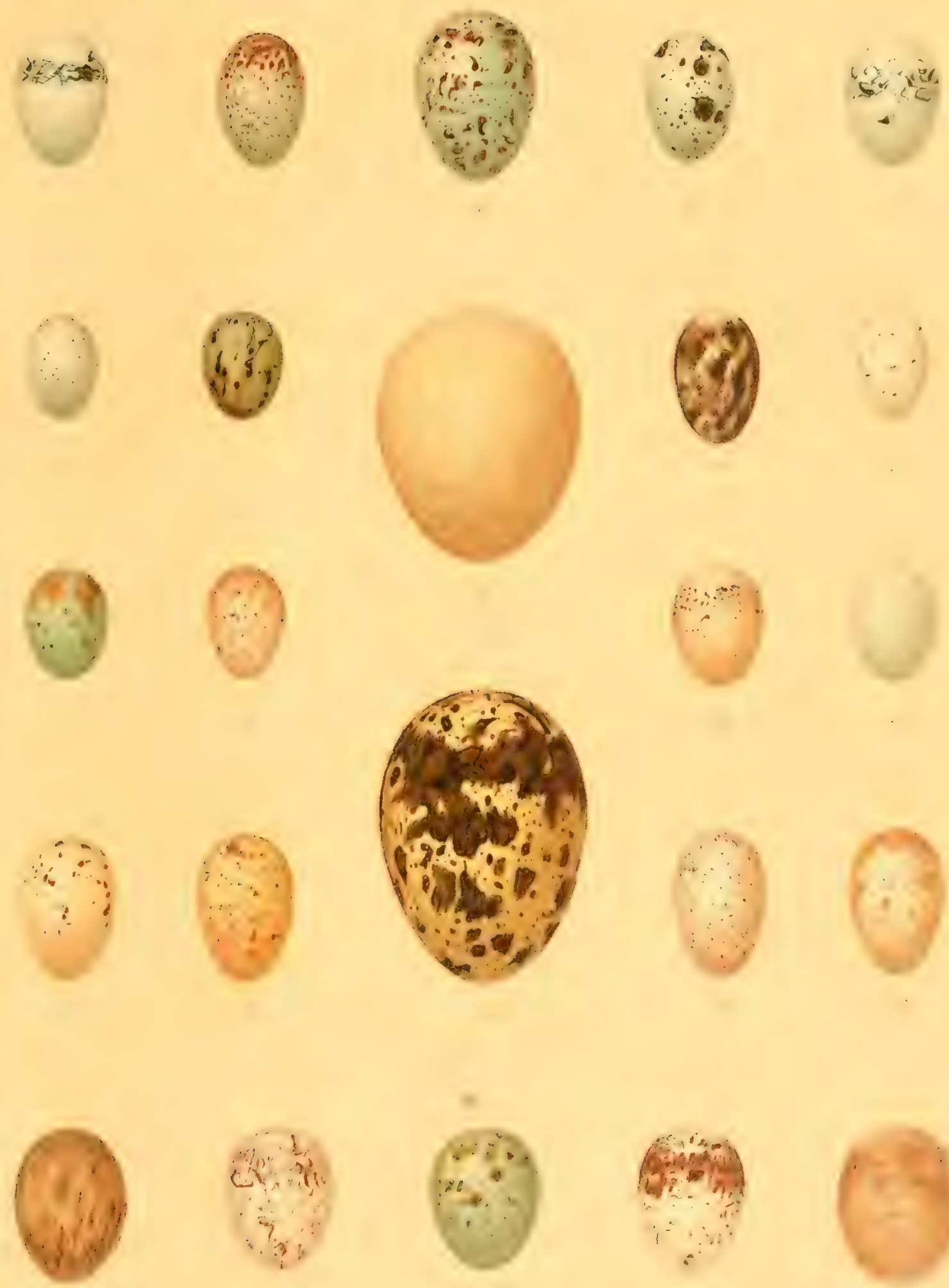



